Prepared in cooperation with the California State Water Resources Control Board

\title{
Environmental Factors Affecting Mercury in Camp Far West Reservoir, California, 2001-03
}

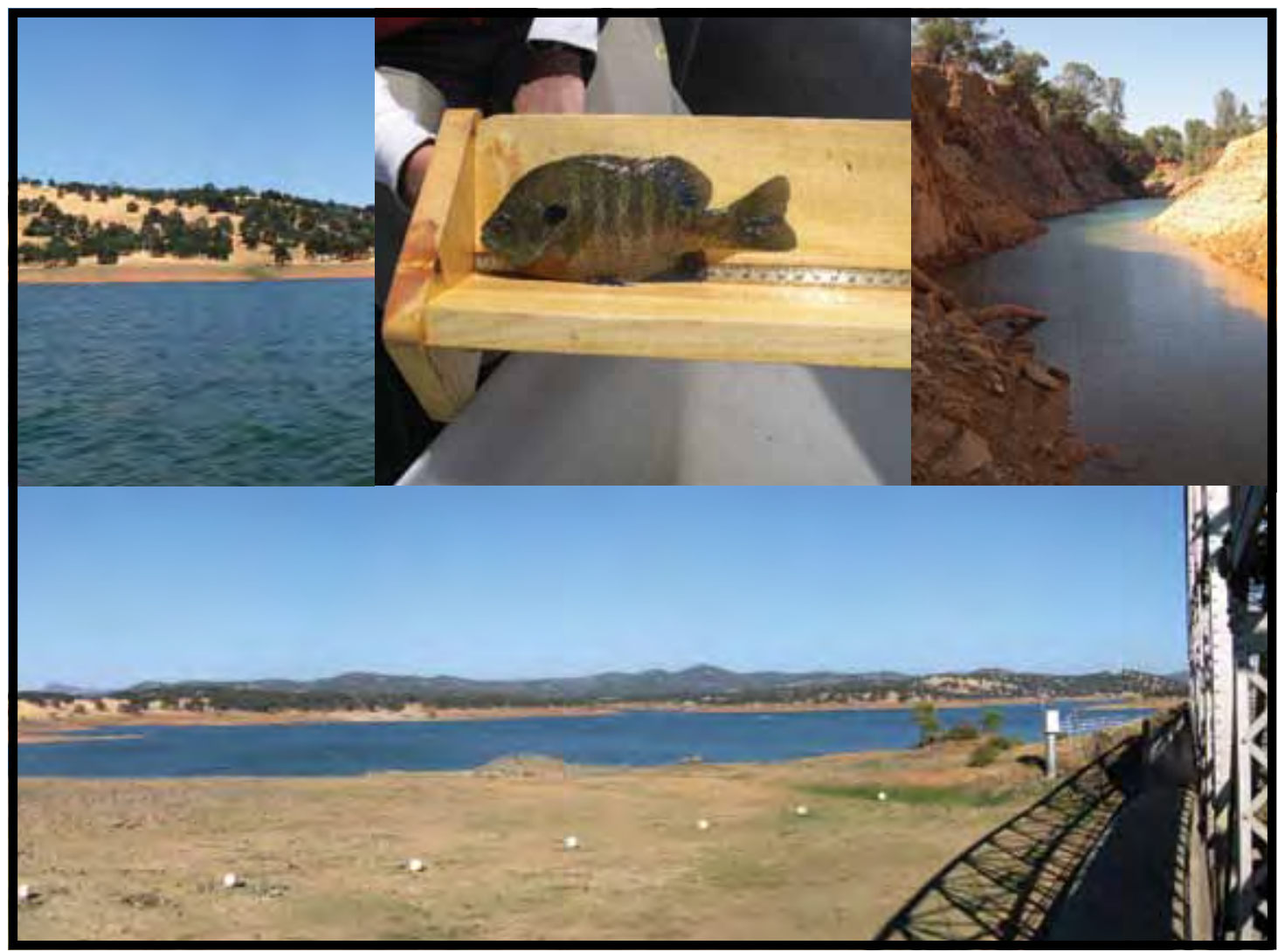

Scientific Investigations Report 2006-5008 
Photographs on cover, clockwise from upper left: Middle reservoir, looking northeast, August 2003 (photograph by C.N. Alpers); bluegill, August 2003 (photograph by M.K. Saiki); Dairy Farm Mine pit lake, August 2003 (photograph by C.N. Alpers); view from Camp Far West Dam, looking southeast, August 2003 (photograph by C.N. Alpers). 


\section{Environmental Factors Affecting Mercury in Camp Far West Reservoir, California, 2001-03}

By Charles N. Alpers, A. Robin Stewart, Michael K. Saiki, Mark C. Marvin-

DiPasquale, Brent R. Topping, Kelly M. Rider, Steven K. Gallanthine, Cynthia A.

Kester, Robert O. Rye, Ronald C. Antweiler, and John F. De Wild

Prepared in cooperation with the

California State Water Resources Control Board

Scientific Investigations Report 2006-5008 


\section{U.S. Department of the Interior DIRK KEMPTHORNE, Secretary}

\section{U.S. Geological Survey \\ Mark D. Myers, Director}

\section{U.S. Geological Survey, Reston, Virginia: 2008}

For product and ordering information:

World Wide Web: http://www.usgs.gov/pubprod

Telephone: 1-888-ASK-USGS

For more information on the USGS - the Federal source for science about the Earth, its natural and living resources, natural hazards, and the environment:

World Wide Web: http://www.usgs.gov

Telephone: 1-888-ASK-USGS

Any use of trade, product, or firm names is for descriptive purposes only and does not imply endorsement by the U.S. Government.

Although this report is in the public domain, permission must be secured from the individual copyright owners to reproduce any copyrighted materials contained within this report.

Suggested citation:

Alpers, C.N., Stewart, A.R., Saiki, M.K., Marvin-DiPasquale, M.C., Topping, B.R., Rider, K.M., Gallanthine, S.K., Kester, C.A., Rye, R.O., Antweiler, R.C., and De Wild, J.F., 2008, Environmental factors affecting mercury in Camp Far West Reservoir, California, 2001-03: U.S. Geological Survey Scientific Investigations Report 2006-5008, 358 p. 


\section{Contents}

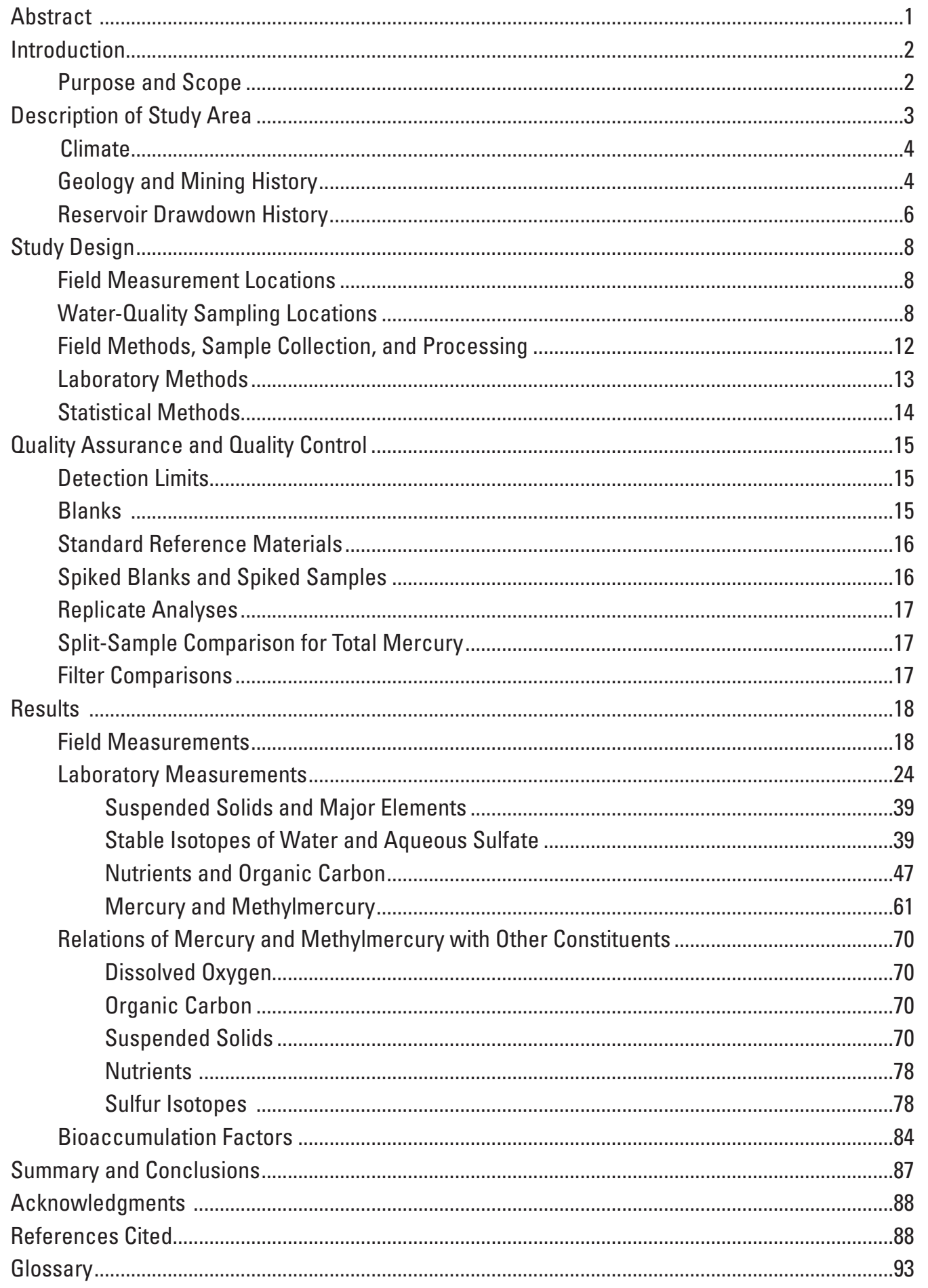




\section{Contents-Continued}

Appendix A. Plots Showing Relations of Reservoir Storage, Surface Water Elevation, and Time, Camp Far West Reservoir, California.

Appendix B. Tables Describing Sampling Stations and Frequency of Sampling, Camp Far West Reservoir and Vicinity, California.

Appendix C. Tables of Data Describing Water-Column Profiles, Camp Far West Reservoir, California

Appendix D. Plots Showing Water-Column Depth Profiles of Temperature, Dissolved Oxygen, $\mathrm{pH}$, and Specific Conductance, Camp Far West Reservoir, California, 2001-03 .......92

Appendix E. Tables of Data Related to Quality Assurance and Quality Control.............................92

Appendix F. Quality Assurance and Quality Control Figures ....................................................92

Appendix G. Data for Total Mercury, Other Trace Elements, Major Elements, and Chlorophyll

Appendix H. Data Tables for Methylmercury Bioaccumulation Factors, Camp Far West Reservoir, California

\section{Figures}

Figure 1. Map showing location of Camp Far West Reservoir in the Bear River Watershed, California

Figure 2. Bar charts showing monthly precipitation data, 1999-2003: (A) Grass Valley, California, (B) Auburn, California

Figure 3. Graph showing average daily temperature at Auburn, California, 2000-2003

Figure 4. Time-series plots showing water storage volume in Camp Far West Reservoir, California: (A) Actual monthly storage for 1999-2004 and long-term monthly average (1964-2000), (B) Monthly data for 1963-2004

Figure 5. Map showing locations and site numbers for monitoring stations for water-quality monitoring and water-column depth profiles, Camp Far West Reservoir, California

Figure 6. Plots showing water-column depth profiles of field measurements (temperature, dissolved oxygen, $\mathrm{pH}$, and specific conductance) quarterly from fall 2001 to summer 2003 at Camp Far West Reservoir, California: $(A)$ Site 2, Lower Reservoir, Thalweg, (B) Site 4, Mid-Reservoir, Thalweg, (C) Site 5, Bear River Arm

Figure 7. Time-series plots showing field measurements for sampling stations in Camp Far West Reservoir, California, 2001-03: $(A)$ Temperature, $(B)$ Dissolved oxygen, $(C) \mathrm{pH},(D)$ Specific conductance

Figure 8. Time-series plots showing concentrations of water-quality constituents for sampling stations in Camp Far West Reservoir, California, 2001-03: $(A)$ Suspended solids, $(B)$ Particulate iron, $(C)$ Calcium in filtered water, $(D)$ Sulfate in filtered water

Figure 9. Plots showing relations among major elements in filtered water in Camp Far West Reservoir, California, 2001-03: (A) Sodium and chloride, $(B)$ Calcium and chloride, $(C)$ Sulfate and chloride, $(D)$ Calcium and sulfate

Figure 10. Plots showing relation between oxygen and hydrogen isotopes in unfiltered water: (A) Bear River stations, including Camp Far West Reservoir, 2001-03, (B) Camp Far West Reservoir stations, 1999-2003. 


\section{Figures-Continued}

Figure 11. Time-series plots showing stable isotope data for Camp Far West Reservoir, California, 2001-03: $(A)$ Oxygen isotopes in water, $(B)$ Sulfur isotopes in aqueous sulfate.

Figure 12. Plots showing relations between sulfur isotopes in aqueous sulfate and other water-quality constituents in Camp Far West Reservoir, California, 2001-03:

$(A)$ Oxygen isotopes in aqueous sulfate, $(B)$ Sulfate concentration in filtered water, $(C)$ Calcium concentration in filtered water

Figure 13. Time-series plots of total phosphorus concentrations in Camp Far West Reservoir, California, 2001-03: (A) Unfiltered water, $(B)$ Filtered water, (C) Particulate

Figure 14. Time-series plots of nitrogen species concentrations in Camp Far West Reservoir, California, 2001-03: (A) Ammonia and organic nitrogen in unfiltered water, $(B)$ Ammonia and organic nitrogen in filtered water, $(C)$ Nitrite plus nitrate in filtered water

Figure 15. Time-series plots of carbon species concentrations in Camp Far West Reservoir, California, 2001-03: (A) Particulate organic carbon, $(B)$ Dissolved organic carbon

Figure 16. Plots of some relations among concentrations of nutrients and carbon species in water samples from Camp Far West Reservoir, California, 2001-03:

$(A)$ Total phosphorus in unfiltered and filtered water, $(B)$ Ammonia plus organic nitrogen in unfiltered and filtered water, $(C)$ Particulate and dissolved organic carbon

Figure 17. Plots showing relations between concentrations of phosphorus and nitrogen compounds in water samples from Camp Far West Reservoir, California, 2001-03: $(A)$ total inorganic nitrogen and orthophosphate in filtered water (data from Kuwabara and others, 2003), (B) ammonia plus organic nitrogen and total phosphorus in unfiltered water, $(C)$ ammonia plus organic nitrogen and total phosphorus in filtered water

Figure 18. Time-series plots showing concentrations of mercury and methylmercury species for sampling stations in Camp Far West Reservoir, California, 2001-03: $(A)$ Total mercury in unfiltered water, $(B)$ Total mercury in filtered water, $(C)$ Total mercury, particulate, $(D)$ Methylmercury in unfiltered water, (E) Methylmercury in filtered water, $(F)$ Methylmercury, particulate

Figure 19. Plot showing relation between concentrations in unfiltered and filtered water samples from Camp Far West Reservoir, California, 2001-03: (A) Total mercury, $(B)$ Methylmercury

Figure 20. Plot showing relation between total mercury and methylmercury concentrations in water samples from Camp Far West Reservoir, California, 2001-03: $(A)$ Unfiltered water, $(B)$ Filtered water

Figure 21. Time-series plots showing ratio of methylmercury to total mercury in water samples from Camp Far West Reservoir, California, 2001-03: (A) Unfiltered water, $(B)$ Filtered water

Figure 22. Plot showing relation between ratio of methylmercury to total mercury in unfiltered and filtered water, Camp Far West Reservoir, California, 2001-03:

$(A)$ Linear plot indicating results of least-squares regression $(B)$ Log-log plot showing regression line

Figure 23. Plots showing relations between concentrations of methylmercury and dissolved oxygen in Camp Far West Reservoir, California, 2001-03: (A) unfiltered methylmercury, $(B)$ filtered methylmercury 


\section{Figures-Continued}

Figure 24. Plots showing relations between concentrations of mercury and carbon species in water samples from Camp Far West Reservoir, California, 2001-03: (A) Unfiltered total mercury and dissolved organic carbon, (B) Filtered total mercury and dissolved organic carbon, $(C)$ Particulate total mercury and particulate organic carbon, $(D)$ Unfiltered methylmercury and dissolved organic carbon, $(E)$ Filtered methylmercury and dissolved organic carbon, $(F)$ Particulate methylmercury and particulate organic carbon

Figure 25. Plots showing relations between concentrations of total mercury and suspended solids in water samples from Camp Far West Reservoir, California, 2001-03: (A) Unfiltered total mercury and total suspended solids, $(B)$ Unfiltered total mercury and suspended silt plus clay, $(C)$ Particulate total mercury and total suspended solids, $(D)$ Particulate total mercury and suspended silt plus clay

Figure 26. Plots showing relations between concentrations of methylmercury and suspended solids in water samples from Camp Far West Reservoir, California, 2001-03: (A) Unfiltered methylmercury and suspended solids, (B) Unfiltered methylmercury and suspended silt plus clay, (C) Particulate methylmercury and suspended solids, (D) Particulate methylmercury and suspended silt plus clay

Figure 27. Plots showing relations between concentrations of mercury species and phosphorus in water samples from Camp Far West Reservoir, California, 2001-03: $(A)$ Total mercury and total phosphorus in unfiltered water, $(B)$ Particulate total mercury and particulate total phosphorus, $(C)$ Methylmercury and total phosphorus in unfiltered water, $(D)$ Particulate methylmercury and particulate total phosphorus

Figure 28. Plots showing relations between mercury and nitrogen concentrations in water samples from Camp Far West Reservoir, California, 2001-03: $(A)$ total mercury and ammonia plus organic nitrogen in unfiltered water, $(B)$ total mercury and ammonia plus organic nitrogen in filtered water, $(C)$ total particulate mercury and particulate ammonia plus organic nitrogen, $(D)$ methylmercury and ammonia plus organic nitrogen in unfiltered water

Figure 29. Plots showing relation between sulfur isotopes in aqueous sulfate and total mercury in water, 2001-03: $(A)$ total mercury in unfiltered water, $(B)$ total mercury in filtered water

Figure 30. Plots showing relations of total length and total mercury in tissue of selected fishes and crayfish, Camp Far West Reservoir, 2002-03: $(A)$ Spotted bass, $(B)$ Bluegill, $(C)$ Threadfin shad, $(D)$ Crayfish. Dashed vertical lines represent boundaries between size classes selected for calculation of methylmercury bioaccumulation factors

Figure 31. Plot showing relation of average and standard deviation of total length and total mercury in fillet tissue in selected size classes of fishes and crayfish from Camp Far West Reservoir, California, 2002-03: $(A)$ Spotted bass, $(B)$ Bluegill, $(C)$ Threadfin shad, $(D)$ Crayfish 


\section{Tables}

Table 1. Data for water-quality parameters measured in the field, Camp Far West

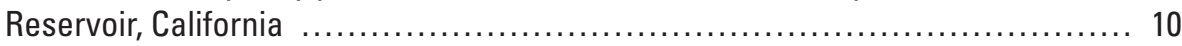

Table 2. Data for suspended solids in water samples, Camp Far West Reservoir, California

Table 3. Data for major anions (chloride, sulfate, and alkalinity, a proxy for bicarbonate) in filtered water samples, Camp Far West Reservoir, California ..... 27

Table 4. Data for oxygen and sulfur isotopes in aqueous sulfate and oxygen and hydrogen isotopes in water, Camp Far West Reservoir, California $\ldots \ldots \ldots \ldots \ldots 29$

Table 5. Data for nutrients and organic carbon in water samples, Camp Far West Reservoir, California

Table 6. Best values for concentrations of total mercury in water samples, Camp Far West Reservoir, California ................................................ 35

Table 7. Data for methylmercury in water samples, Camp Far West Reservoir, California ... 37

Table 8. Statistical data for field measurements and suspended solids concentrations, Camp Far West Reservoir, California ................................... 40

Table 9. Statistical data for mercury and methylmercury concentrations in water, Camp Far West Reservoir, California

Table 10. Summary of methylmercury bioaccumulation factors, Camp Far West Reservoir, California, 2002-03 


\section{Conversion Factors}

\begin{tabular}{|c|c|c|}
\hline Multiply & By & To obtain \\
\hline \multicolumn{3}{|c|}{ Length } \\
\hline inch (in.) & 2.54 & centimeter $(\mathrm{cm})$ \\
\hline inch (in.) & 25.4 & millimeter (mm) \\
\hline foot (ft) & 0.3048 & meter (m) \\
\hline mile (mi) & 1.609 & kilometer (km) \\
\hline yard (yd) & 0.9144 & meter $(\mathrm{m})$ \\
\hline \multicolumn{3}{|c|}{ Volume } \\
\hline ounce, fluid (fl. oz) & 0.02957 & liter (L) \\
\hline pint (pt) & 0.4732 & liter (L) \\
\hline quart (qt) & 0.9464 & liter (L) \\
\hline gallon (gal) & 3.785 & liter (L) \\
\hline gallon (gal) & 0.003785 & cubic meter $\left(\mathrm{m}^{3}\right)$ \\
\hline million gallons (Mgal) & 3,785 & cubic meter $\left(\mathrm{m}^{3}\right)$ \\
\hline cubic foot $\left(\mathrm{ft}^{3}\right)$ & 0.02832 & cubic meter $\left(\mathrm{m}^{3}\right)$ \\
\hline cubic yard $\left(\mathrm{yd}^{3}\right)$ & 0.7646 & cubic meter $\left(\mathrm{m}^{3}\right)$ \\
\hline cubic mile $\left(\mathrm{mi}^{3}\right)$ & 4.168 & cubic kilometer $\left(\mathrm{km}^{3}\right)$ \\
\hline acre-foot (acre-ft) & 1,233 & cubic meter $\left(\mathrm{m}^{3}\right)$ \\
\hline acre-foot (acre-ft) & 0.001233 & cubic hectometer $\left(\mathrm{hm}^{3}\right)$ \\
\hline \multicolumn{3}{|c|}{ Flow rate } \\
\hline acre-foot per year (acre-ft/yr) & 1,233 & cubic meter per year $\left(\mathrm{m}^{3} / \mathrm{yr}\right)$ \\
\hline cubic foot per second $\left(\mathrm{ft}^{3} / \mathrm{s}\right)$ & 0.02832 & cubic meter per second $\left(\mathrm{m}^{3} / \mathrm{s}\right)$ \\
\hline gallon per minute (gal/min) & 0.06309 & liter per second (L/s) \\
\hline \multicolumn{3}{|c|}{ Mass } \\
\hline ounce, avoirdupois (oz) & 28.35 & gram (g) \\
\hline pound, avoirdupois (lb) & 0.4536 & kilogram (kg) \\
\hline ton, short (2,000 lb) & 0.9072 & megagram (Mg) \\
\hline \multicolumn{3}{|c|}{ Pressure } \\
\hline bar & 100 & kilopascal (kPa) \\
\hline inch of mercury at $60^{\circ} \mathrm{F}$ (in $\mathrm{Hg}$ ) & 3.377 & kilopascal (kPa) \\
\hline
\end{tabular}

Temperature in degrees Celsius $\left({ }^{\circ} \mathrm{C}\right)$ may be converted to degrees Fahrenheit $\left({ }^{\circ} \mathrm{F}\right)$ as follows:

$$
{ }^{\circ} \mathrm{F}=\left(1.8 \mathrm{x}^{\circ} \mathrm{C}\right)+32 \text {. }
$$

Specific conductance is given in microsiemens per centimeter at 25 degrees Celsius $(\mu \mathrm{S} / \mathrm{cm}$ at $\left.25^{\circ} \mathrm{C}\right)$.

Concentrations of chemical constituents in water are given either in milligrams per liter ( $\mathrm{mg} / \mathrm{L})$, micrograms per liter ( $\mu \mathrm{g} / \mathrm{L})$, or nanograms per liter $(\mathrm{ng} / \mathrm{L})$. 


\title{
Datums
}

Vertical coordinate information is referenced to the National Geodetic Vertical Datum of 1929

(NGVD 29).

Elevation, as used in this report, refers to distance above the vertical datum.

Horizontal coordinate information is referenced to North American Datum of 1983 (NAD 83).

\section{Acronyms}

\author{
ASTM, American Society for Testing \\ and Materials \\ BAF, bioaccumulation factor \\ BRA, Bear River Arm (site 5) \\ CDT, Cañon Diablo Troilite \\ CFWR, Camp Far West Reservoir \\ CRV, certified reference value \\ CVAAS, cold vapor atomic-absorption \\ spectrometry \\ CVAFS, cold vapor atomic-fluorescence \\ spectrometry \\ DFA, Dairy Farm Arm (site 6) \\ DFI, impoundments near the Dairy \\ Farm Mine (site 9) \\ DFP, Dairy Farm Mine pit lake (site 8) \\ DI, deionized (water) \\ D0, dissolved oxygen \\ DOC, dissolved organic carbon \\ EPA, U.S. Environmental Protection Agency \\ FDA, Food and Drug Administration \\ GC, gas chromatography \\ G.I., gastrointestinal \\ GMWL, Global Meteoric Water Line \\ IAEA, International Atomic Energy Agency \\ IC, ion chromatography \\ ICP-AES, inductively coupled plasma- \\ atomic emission spectrometry \\ ICP-MS, inductively coupled plasma- \\ mass spectrometry \\ $M D L$, method detection limit \\ MRS, Mid-Reservoir, Shallow (site 3) \\ MRT, Mid-Reservoir, Thalweg (site 4) \\ NAWQA, National Water-Quality \\ Assessment Program \\ NRCC, National Research Council Canada \\ NRP, National Research Program \\ POC, particulate organic carbon \\ $\mathrm{QA}$, quality assurance \\ $\mathrm{OC}$, quality control \\ QFF, quartz fiber filter \\ RCA, Rock Creek Arm (site 7) \\ RPD, relative percent difference \\ $R S D$, relative standard deviation \\ $\mathrm{SC}$, specific conductance \\ SRM, standard reference material \\ SRWS, standard reference water sample \\ SSC, suspended solids concentration \\ SSWD, South Sutter Water District \\ SWRCB, State Water Resources Control Board \\ $T L$, trophic level \\ USEPA, United States Environmental \\ Protection Agency \\ USGS, United States Geological Survey \\ VSMOW, Vienna Standard Mean Ocean Water \\ WMRL, Wisconsin Mercury Research \\ Laboratory
}




\section{Abbreviations and Symbols}

cm, centimeter

g, gram

$\mathrm{kg}$, kilogram

$\mathrm{L}$, liter

$\mathrm{mg}$, milligram

$\mathrm{mL}$, milliliter

$\mu \mathrm{g}$, microgram

$\mu \mathrm{m}$, micrometer

$\mu \mathrm{mol}$, micromole

$\mathrm{M} \Omega$-cm, megaohm-centimeter ng, nanogram

$\mathrm{ng} / \mathrm{L}$, nanogram per liter

ppb, part per billion

ppm, part per million

wt, weight

S, second

$>$, greater than

$<$, less than

$\%$, percent

$\%$, permil

\section{Chemical Notation}

Elements

$\begin{array}{lll}\text { Al, aluminum } & \text { Gd, gadolinium } & \text { Re, rhenium } \\ \text { As, arsenic } & \text { Ho, holmium } & \text { Rh, rhodium } \\ \text { B, boron } & \mathrm{Hg} \text {, mercury } & \text { Sb, antimony } \\ \text { Ba, barium } & \text { In, indium } & \text { Se, selenium } \\ \text { Be, beryllium } & \text { Ir, iridium } & \text { Sm, samarium } \\ \text { Bi, bismuth } & \mathrm{K} \text {, potassium } & \text { Sn, tin } \\ \text { B, boron } & \text { La, lanthanum } & \text { Sr, strontium } \\ \text { Ca, calcium } & \mathrm{Li} \text {, lithium } & \text { Tb, terbium } \\ \text { Cd, cadmium } & \text { Lu, lutetium } & \text { Te, tellurium } \\ \text { Ce, cerium } & \mathrm{Mg} \text {, magnesium } & \text { Th, thorium } \\ \text { Cl, chlorine } & \mathrm{Mn} \text {, manganese } & \mathrm{Tl} \text {, thallium } \\ \text { Co, cobalt } & \mathrm{N}, \text { nitrogen } & \mathrm{Tm} \text {, thulium } \\ \text { Cr, chromium } & \mathrm{Na} \text {, sodium } & \mathrm{U} \text {, uranium } \\ \text { Cs, cesium } & \mathrm{Nd} \text {, neodymium } & \mathrm{V} \text {, vanadium } \\ \text { Cu, copper } & \mathrm{Ni} \text {, nickel } & \mathrm{Y} \text {, yttrium } \\ \text { Dy, dysprosium } & \mathrm{P} \text {, phosphorus } & \mathrm{Yb} \text {, ytterbium } \\ \text { Er, erbium } & \mathrm{Pb} \text {, lead } & \mathrm{Zn} \text {, zinc } \\ \text { Eu, europium } & \mathrm{Pr} \text {, praseodymium } & \mathrm{Zr} \text {, zirconium } \\ \text { Fe, iron } & \mathrm{Rb} \text {, rubidium } & \end{array}$




\section{Compounds, Isotopes, and Other Chemical Notation}

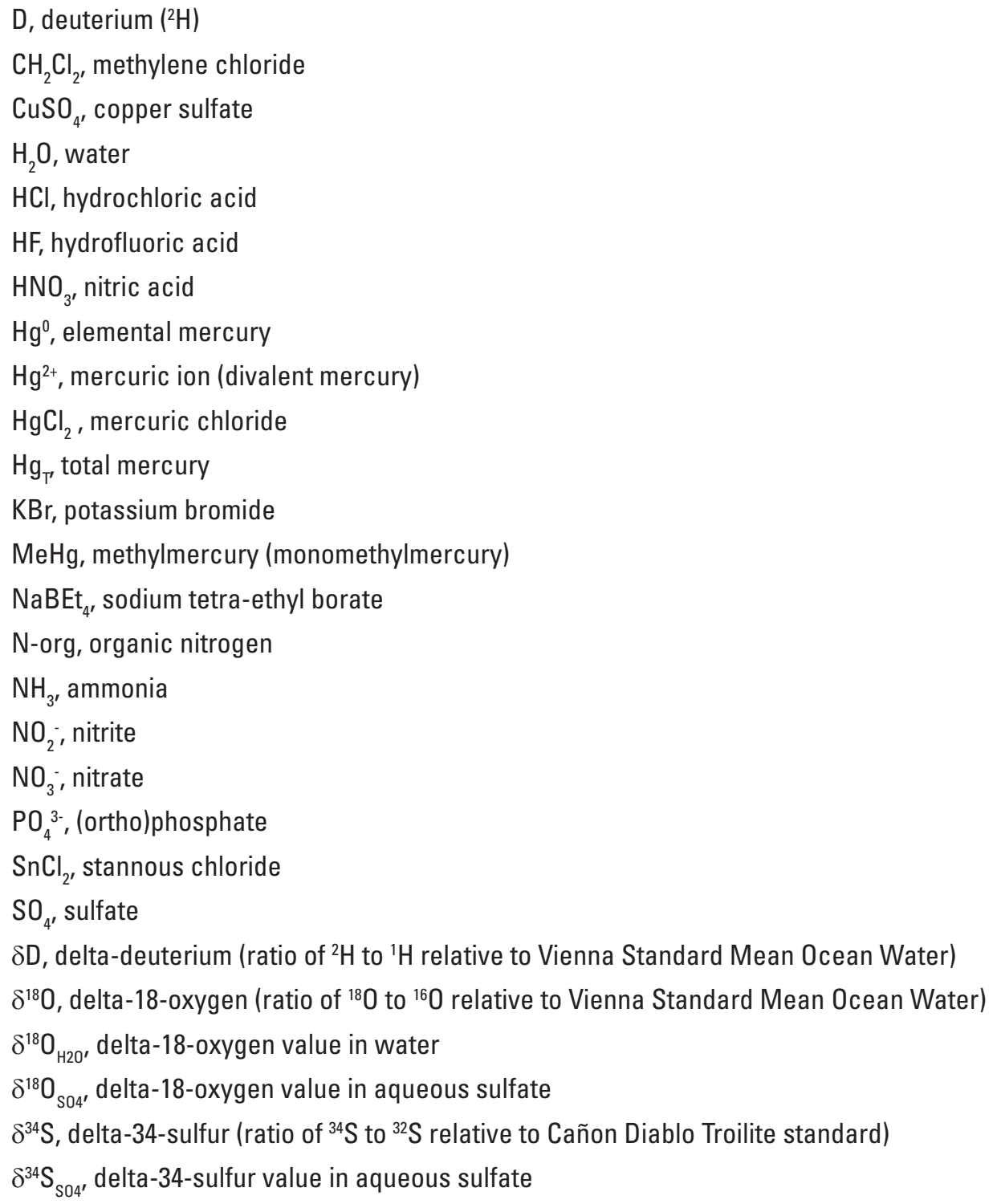


This page intentionally left blank 


\title{
Environmental Factors Affecting Mercury in Camp Far West Reservoir, California, 2001-03
}

\author{
By Charles N. Alpers, A. Robin Stewart, Michael K. Saiki, Mark C. Marvin-DiPasquale, Brent R. Topping, \\ Kelly M. Rider, Steven K. Gallanthine, Cynthia A. Kester, Robert O. Rye, Ronald C. Antweiler, and \\ John F. De Wild
}

\section{Abstract}

This report documents water quality in Camp Far West Reservoir from October 2001 through August 2003. The reservoir, located at approximately 300 feet above sea level in the foothills of the northwestern Sierra Nevada, California, is a monomictic lake characterized by extreme drawdown in the late summer and fall. Thermal stratification in summer and fall is coupled with anoxic conditions in the hypolimnion. Water-quality sampling was done at approximately 3-month intervals on eight occasions at several stations in the reservoir, including a group of three stations along a flow path in the reservoir: an upstream station in the Bear River arm (principal tributary), a mid-reservoir station in the thalweg (prereservoir river channel), and a station in the deepest part of the reservoir, in the thalweg near Camp Far West Dam. Stations in other tributary arms of the reservoir included those in the Rock Creek arm of the reservoir, a relatively low-flow tributary, and the Dairy Farm arm, a small tributary that receives acidic, metal-rich drainage seasonally from the inactive Dairy Farm Mine, which produced copper, zinc, and gold from underground workings and a surface pit.

Several water-quality constituents varied significantly by season at all sampling stations, including major cations and anions, total mercury (filtered and unfiltered samples), nitrogen (ammonia plus organic), and total phosphorus. A strong seasonal signal also was observed for the sulfurisotope composition of aqueous sulfate from filtered water. Although there were some spatial differences in water quality, the seasonal variations were more profound. Concentrations of total mercury (filtered and unfiltered water) were highest during fall and winter; these concentrations decreased at most stations during spring and summer. Anoxic conditions developed in deep parts of the reservoir during summer and fall in association with thermal stratification. The highest concentrations of methylmercury in unfiltered water were observed in samples collected during summer from deepwater stations in the anoxic hypolimnion. In the shallow (less than 14 meters depth) oxic epilimnion, concentrations of methylmercury in unfiltered water were highest during the spring and lowest during the fall. The ratio of methylmercury to total mercury $\left(\mathrm{MeHg} / \mathrm{Hg}_{\mathrm{T}}\right)$ increased systematically from winter to spring to summer, largely in response to the progressive seasonal decrease in total mercury concentrations, but also to some extent because of increases in $\mathrm{MeHg}$ concentrations during summer.

Water-quality data for Camp Far West Reservoir are used in conjunction with data from linked studies of sediment and biota to develop and refine a conceptual model for mercury methylation and bioaccumulation in the reservoir and the lower Bear River watershed. It is hypothesized that $\mathrm{MeHg}$ is produced by sulfate-reducing bacteria in the anoxic parts of the water column and in shallow bed sediment. Conditions were optimal for this process during late summer and fall. Previous work has indicated that Camp Far West Reservoir is a phosphate-limited system-molar ratios of inorganic nitrogen to inorganic phosphorus in filtered water were consistently greater than 16 (the Redfield ratio), sometimes by orders of magnitude. Therefore, concentrations of orthophosphate were expectedly very low or below detection at all stations during all seasons. It is further hypothesized that iron-reducing bacteria facilitate release of phosphorus from iron-rich sediments during summer and early fall, stimulating phytoplankton growth in the fall and winter, and that the MeHg produced in the hypolimnion and metalimnion is released to the entire water column in the late fall during reservoir destratification (vertical mixing).

Mercury bioaccumulation factors (BAF) were computed using data from linked studies of biota spanning a range of trophic position: zooplankton, midge larvae, mayfly nymphs, crayfish, threadfin shad, bluegill, and spotted bass. Significant increases in total mercury in tissue with increasing organism size were observed for all three fish species and for crayfish. The BAF values were computed using the average methylmercury concentration (wet) in biota divided by the arithmetic mean concentration of methylmercury in filtered water (0.04 nanograms per liter). As expected, the BAF values increased systematically with increasing trophic position. Values of BAF were 190,000 for zooplankton; 470,000 to 930,000 for three taxa of invertebrates; 2.7 million for threadfin shad (whole body); 4.2 million for bluegill (fillet); and 10 million for spotted bass (fillet). The BAF values are high compared with those for biota in other reservoirs in northern California and elsewhere, indicating relatively efficient biomagnification of mercury in Camp Far West Reservoir. 


\section{Introduction}

Extensive mercury use during historical gold mining and mineral processing resulted in widespread mercury contamination and bioaccumulation of methylmercury in watersheds in the northwestern Sierra Nevada (Slotton and others 1997; Alpers and Hunerlach, 2000; Alpers and others, 2005a). Estimates based on historical documents and mining records (Churchill, 2000) indicate that up to 10 million pounds of mercury were lost to the environment in California from mining of placer gold during the latter half of the 19th century and the early 20th century; in addition, about 3 million pounds of mercury were lost from stamp mills associated with hardrock mining. Most of the hardrock mining activity in California was in the northern Sierra Nevada.

In 1999, the U.S. Geological Survey began leading a multi-agency, multi-disciplinary investigation of mercury contamination in the watersheds of the Bear River, Deer Creek, and South Yuba River (fig. 1), with emphasis on effects of historical placer gold mining (Alpers and Hunerlach, 2000; Hunerlach and Alpers, 2003; Alpers and others, 2005a, 2005b). Elevated mercury concentrations in fish from reservoirs and streams in these three watersheds were documented by May and others (2000). Of the five reservoirs tested by May and others (2000), Camp Far West Reservoir (CFWR) had fish containing the highest levels of mercury. Spotted bass, the top predator in CFWR, had total mercury concentrations ranging from 0.59 to $1.5 \mu \mathrm{g} / \mathrm{g}$ (microgram per gram, wet weight) with a mean value of $0.92 \mu \mathrm{g} / \mathrm{g}$. These concentrations led the State of California to issue a public advisory recommending no consumption of spotted bass from CFWR by women of childbearing age and children 17 years of age and under (Klasing and Brodberg, 2003), and recommending limited consumption of all bass species and other sport fish throughout the Bear River and Yuba River watersheds for all fish consumers.

Another regulatory consequence of documenting elevated mercury in fish tissue for reservoirs and streams in the BearYuba watersheds (May and others, 2000) was the inclusion of several water bodies in this area on the State of California's list of water bodies with impaired beneficial uses, under section 303(d) of the Clean Water Act. The 303(d) listings require that the listed water bodies be scheduled for Total Maximum Daily Load (TMDL) assessments. The TMDL assessment for Camp Far West Reservoir is scheduled for 2011 (California Regional Water Quality Control Board-Central Valley Region, 2003).

A detailed follow-up study of mercury bioaccumulation in the food web of CFWR was initiated in 2001 by the USGS and the California State Water Resources Control Board as a key component in an integrated effort referred to as the Bear River Mercury Cycling Project (BRMCP). Other components of the BRMCP include studies of mercury methylation potential rates and flux into the water column from bed sediment in CFWR (Kuwabara and others, 2003), methylmercury bioaccumulation dynamics in the food web of CFWR in relation to water quality (Stewart and others, 2008) mercury and methylmercury mass balance for CFWR and another reservoir in the Bear River watershed (Caruso and others, 2008), and assessment of the methylmercury bioaccumulation factor at reservoir sites (this report) and river sites $\mathrm{n}$ the watershed. A long-term goal of the BRMCP is to provide a sound scientific understanding of mercury cycling so that predictions can be made with reasonable certainty regarding mercury bioaccumulation.

\section{Purpose and Scope}

The overall objectives of the Bear River mercury cycling project are (1) to determine the biogeochemical and hydrologic processes that control mercury methylation, demethylation, and bioaccumulation in the Bear River watershed; (2) to determine mass balances for mercury and methylmercury in Camp Far West and Rollins Reservoirs in the Bear River watershed (fig. 1); (3) to test hypotheses regarding the extent that biogeochemical and ecological factors controlling bioaccumulation of mercury in sport fish help to identify potentially effective control measures (such as reducing nutrients, sulfate, and total mercury either singly or in combination); (4) to determine loads of mercury and methylmercury from the Bear River, Yuba River, and Feather River watersheds for comparison with other tributaries to the Sacramento River and the Sacramento-San Joaquin Delta; and (5) to assist the California State Water Resources Control Board (SWRCB) in evaluating the methodology of the U.S. Environmental Protection Agency (USEPA) for correlating methylmercury concentrations in biota with total mercury concentrations in water using bioaccumulation factors. This report documents water quality in Camp Far West Reservoir from October 2001 through August 2003, providing data that are essential for addressing overall objectives (1), (2), (3), and (5) of the BRMCP. In addition, this report describes the sampling, laboratory, and statistical methods used, and the quality assurance and quality control procedures.

Some aspects of the BRMCP that have been or will be reported separately include determination of mercury and methylmercury fluxes from bed sediments in CFWR (Kuwabara and others, 2003), determination of mercury and methylmercury concentrations in the Bear, Yuba, and Feather Rivers and mass balance of two reservoirs in the Bear River, including CFWR, analysis of mercury bioaccumulation and seasonal dynamics of plankton in CFWR (Stewart and others, 2008), analysis of mercury bioaccumulation in invertebrates and fish in CFWR, and analysis of mercury methylation and demethylation potential rates in CFWR bed sediments. In addition, results of the components of the BRMCP are being synthesized into a summary report. 


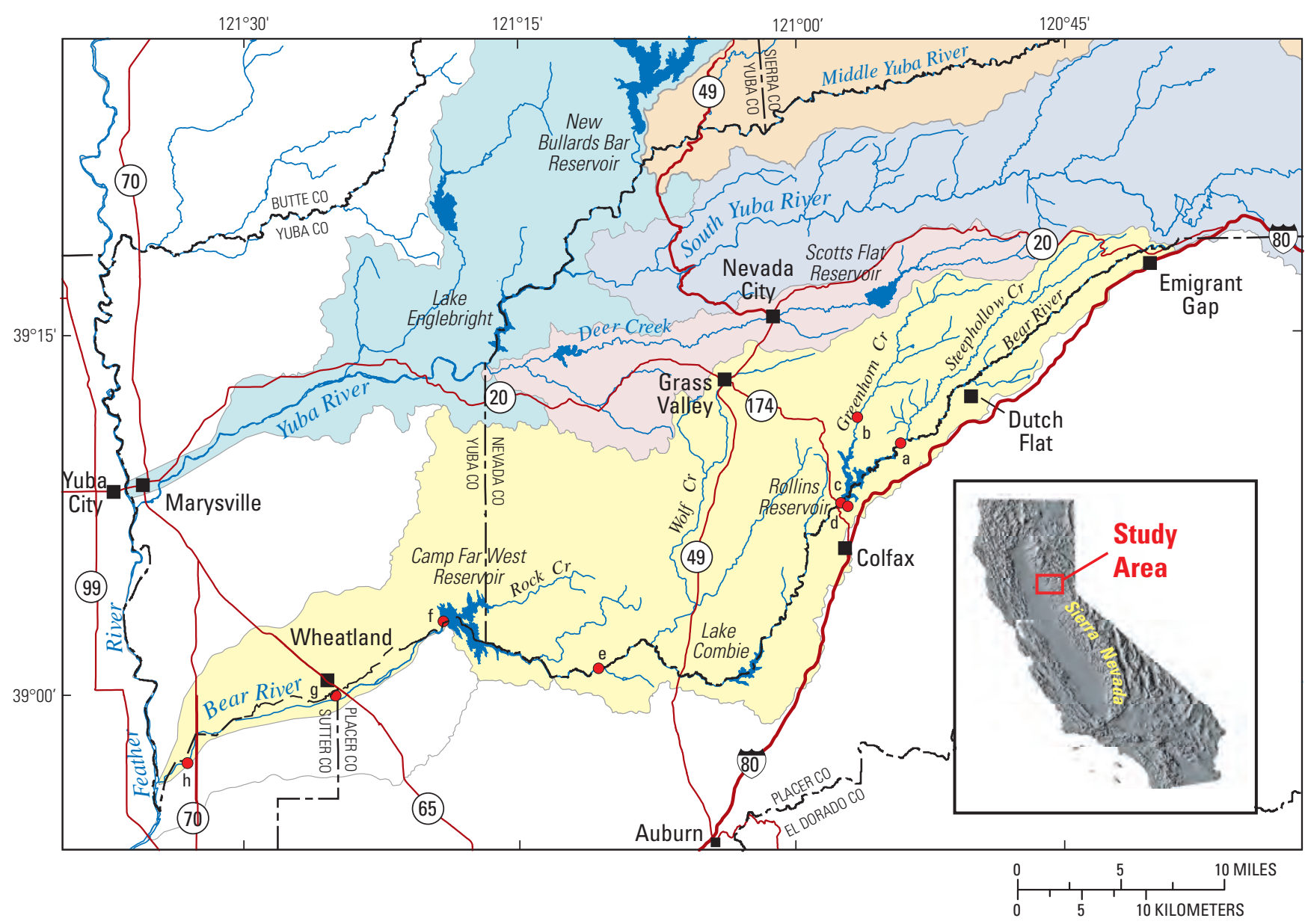

EXPLANATION
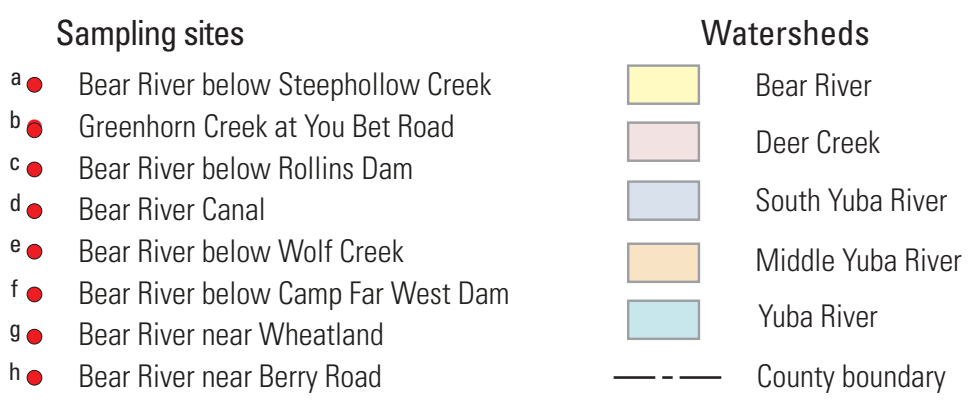

Figure 1. Location of Camp Far West Reservoir in the Bear River Watershed, California.

\section{Description of Study Area}

Camp Far West Reservoir (CFWR) is located in the lower reach of the Bear River, which drains into the Feather River (fig. 1). The Feather River is a major tributary to the Sacramento River, the largest source of water to the San Francisco Bay-Delta Estuary and the origin of drinking water for more than two-thirds of the residents of California. Camp Far West Dam was constructed in 1963 by the South Sutter Water District, which manages the facility. The dam has a height of 185 feet and the spillway elevation is approximately
300 feet above the National Geodetic Vertical Datum of 1929 (NGVD 29). There are two outlets within the dam-one at an elevation of 220 feet above NGVD 29 that leads to a turbine operated by Pacific Gas \& Electric Co. and another at an elevation of 176 feet above NGVD 29 that discharges without power generation. The lower outlet primarily is used when water levels are too low to operate the powerhouse. Flows over the spillway are gaged by the California Department of Water Resources (available from the California Data Exchange Center at http://cdec.water.ca.gov/cgi-progs/ stationInfo?station id=CFW). 


\section{Climate}

The lower Bear River watershed has a Mediterranean climate, with cool, wet winters and hot, dry summers. Monthly precipitation data are shown in figure 2 for Grass Valley and Auburn, California (fig. 1). Nearly all precipitation occurs between November and May. Annual average precipitation during 1999-2002 was 33.9 inches at Grass Valley (Western Regional Climate Center, 2004a) and 49.9 inches at Auburn (Western Regional Climate Center, 2004b). Daily average temperatures (in degrees Fahrenheit, ${ }^{\circ} \mathrm{F}$ ) at Auburn are mostly in the 40s during the winter and in the 70s and 80 s during the summer (fig. 3).

CFWR is a warm, monomictic lake (Wetzel, 1975) typical of the coastal regions of North America. Characteristics of warm monomictic lakes include temperatures remaining above $39^{\circ} \mathrm{F}$ (or 4 degrees Celsius, ${ }^{\circ} \mathrm{C}$ ) year-round, vertical circulation in the winter and spring, and development of thermal stratification during the summer. Destratification or "turnover" occurs typically after the onset of cooler weather in the fall.

\section{Geology and Mining History}

Bedrock in the lower Bear River watershed is primarily composed of volcanic rocks and pyroclastic sedimentary rocks of Jurassic age (Clark, 1976). The volcanic rocks are chiefly mafic volcanic breccia and tuff, with some pillow lava features. In the Bear River arm of CFWR, an intrusive mafic dike strikes northwest across the river channel. There are small outcrops of granitic rocks in the lower watershed, including an area immediately to the south of Lake Combie (fig. 1). Several kilometers farther upstream in the Bear River watershed, the bedrock consists of Paleozoic metasedimentary and metavolcanic rocks of the Calaveras and Shoo Fly formations (Clark, 1976). Tertiary auriferous gravel deposits from the ancestral Yuba River form a north-trending paleochannel, up to 4 miles wide and 600 feet deep, that traverses the watershed near Dutch Flat and Scotts Flat Reservoir (Lindgren, 1911; Yeend, 1974).

The auriferous gravels of the Bear River and other watersheds in the Sierra Nevada were mined extensively from the early 1850s to the mid-1880s by hydraulic mining methods (Bowie, 1905; Averill, 1946). Gilbert (1917) estimated that between the 1850s and the early 1900s, hydraulic mining displaced 254 million cubic yards of gravel and sediment in the Bear River watershed. James (1991, 1993) mapped fluvial deposits of hydraulic mine waste in the Bear River watershed and determined that coarse material has remained in tributaries to a greater extent than predicted by Gilbert (1917). Elemental mercury was used to amalgamate gold in the hydraulic mining process (Bowie, 1905; Averill, 1946), and several million pounds of mercury were likely lost to the environment in the Sierra Nevada because of this practice (Alpers and Hunerlach, 2000; Churchill, 2000; Alpers and others, 2005a). Reconnaissance sampling of water, sediment, and biota by the USGS in the Greenhorn Creek drainage (fig. 1) revealed extensive mercury contamination and bioaccumulation in some "hot spots" associated with historical placer gold mining (Alpers and others, 2005b). Some of the large placer (unconsolidated gravel) gold-mining districts in the watershed are the You Bet-Red Dog district, which drains into Greenhorn and Steephollow Creeks (Alpers and others, 2005b); the Lowell Hill district, which drains into Steephollow Creek; and the Dutch Flat district, which drains into the Dutch Flat Afterbay, a small impoundment on the Bear River near Dutch Flat (fig. 1) (Hunerlach and others, 1999).

Underground mining of hardrock (lode) gold-quartz vein deposits also was important in the Bear River watershed. Several large, underground mines in the Grass Valley mining district are in areas that drain into Wolf Creek, a tributary to the Bear River (fig. 1).These mines include the Empire, Northstar, Providence, Allison Ranch, and Pennsylvania mines (Clark, 1963). The Lava Cap Mine, a hardrock gold mine in the Greenhorn Creek drainage (fig. 1), is the site where an abandoned tailings dam failed during January 1997 and released high-arsenic sediments to downstream environments (CH2M Hill, 2001). Expected contaminants from hardrock gold mining include arsenic, which occurs naturally in pyrite and arsenopyrite associated with the gold-quartz vein deposits, and mercury, which was used for amalgamation in hardrock gold mining in association with stamp mills (Churchill, 2000).

The Dairy Farm Mine produced copper, zinc, and gold from a volcanogenic massive-sulfide deposit along the south shore of CFWR. Along the north shore of CFWR are pyritic outcrops and small exploration pits associated with the same mineralized geologic unit. The Dairy Farm deposit is part of the Foothill Copper-Zinc Belt which extends along the western slope of the Sierra Nevada in eastern California (Heyl, 1948). Although total production history of this mine is not well documented (Loyd, 1995), mining began during the 1860s and continued in the early 1900s and 1930s. During 1915, 350 tons of ore per day were mined and more than 500,000 tons of ore with a grade of more than 1 percent copper were blocked out as reserves (Waring, 1919). The underground mine workings followed the mineralized zone to a total depth of at least 500 feet; this massive-sulfide deposit was 10 to 60 feet thick and more than 600 feet long. A cyanide plant with a capacity of 100 tons per day was active on the site prior to 1915 (Waring, 1919). During the 1930s, gold was recovered from cyanidation of gossan, the oxidized portion of the deposit (Clark, 1963).

Open pit mining at the Dairy Farm Mine during the 1920s and 1930s resulted in a pit that extends more than 150 feet below the original land surface. When the water level in CFWR is high, the pit is inundated by the reservoir, whereas at lower water levels, the pit is hydraulically isolated. 

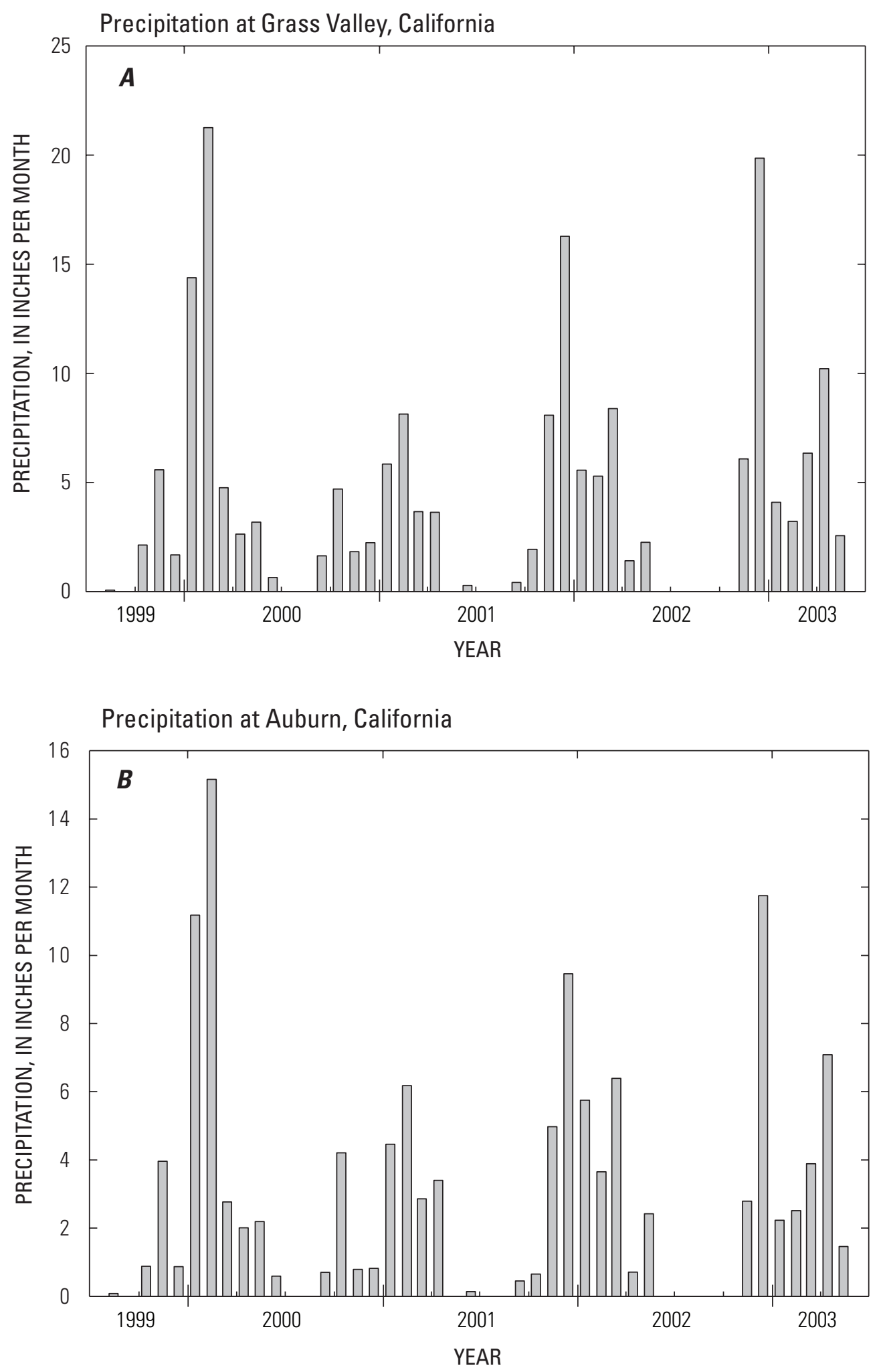

Figure 2. Monthly precipitation data, 1999-2003: $(A)$ Grass Valley, California, $(B)$ Auburn, California. Data from National Oceanographic and Atmospheric Administration, available on California Data Exchange Center website at the following URLs: http://cdec. water.ca.gov/cgi-progs/queryMonthly?GSV and http://cdec.water.ca.gov/cgi-progs/ queryMonthly?AUB 


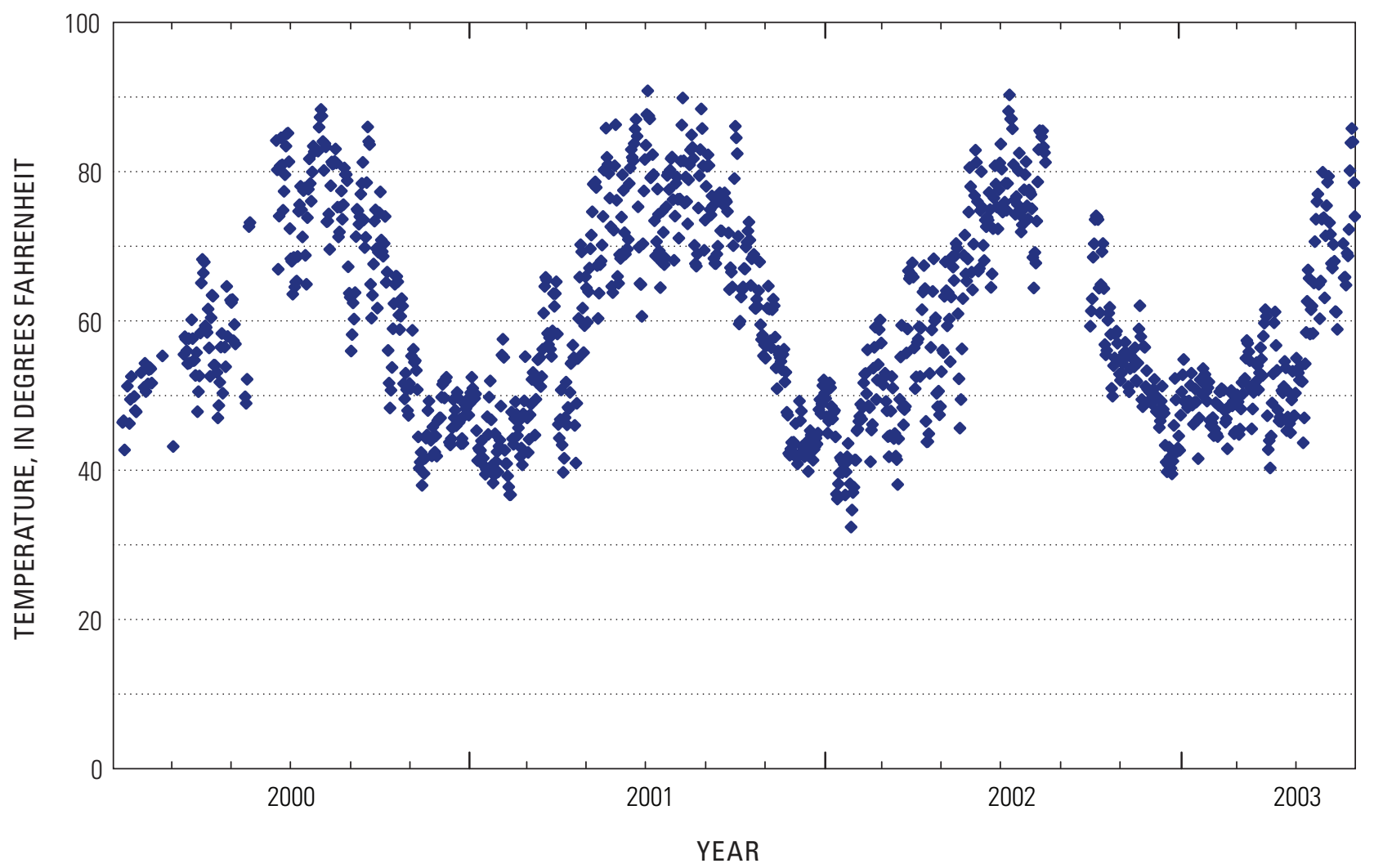

Figure 3. Average daily temperature at Auburn, California, 2000-2003. Data from National Oceanographic and Atmospheric Administration.

The topographic divide that separates the pit lake from the reservoir is at an elevation of about 270 feet above NGVD 29, or about 30 feet below the CFWR spillway elevation. Several acres of the Dairy Farm Mine property were reclaimed, in part, during the 1980s by removing pyrite-bearing waste rock and mill tailings that had led to acidic runoff and poor soil quality (G. Vaughn, California Regional Water Quality Control Board-Central Valley Region, oral commun., 2001). However, the area of the Dairy Farm Mine pit lake was not reclaimed, and the pit lake remains a likely source of trace metals, sulfate, and acidity to CFWR and the lower Bear River.

\section{Reservoir Drawdown History}

The original design storage capacity of CFWR was 104,000 acre-feet, although the current maximum storage may be lower because of sedimentation of an unknown magnitude since 1963. A curve describing reservoir storage as a function of water elevation is given in appendix A (fig. A1). Water management at CFWR is controlled by the South Sutter Water District, with the primary goal of water sales for irrigation purposes. A minimum flow for fish habitat of about $10 \mathrm{ft}^{3} / \mathrm{s}$ (cubic feet per second) is released below CFWR during the summer and fall. Water storage during 1999-2004 is shown in figure 4A. Daily averages for storage were used to compute monthly averages for 1964-2000; then these averages were grouped by specific month and a long-term (37-year) average for each month was computed (California Department of Water Resources, 2005). Long-term, average monthly water levels (1964-2000) are shown as a dotted, repeated, sinusoidal curve in figure $4 \mathrm{~A}$. The minimum longterm, average monthly storage occurs in September $(43,170$ acre-feet) and the maximum in March (101,029 acre-feet); these values are shown as dashed lines in figure $4 \mathrm{~A}$. A timeseries plot of water storage in CFWR for 1963-2004 (fig. 4B) indicates that extreme annual fluctuations are common relative to the long-term, average monthly minimum and maximum (dashed lines). Reservoir drawdown during fall 2002, 2003, and 2004 was considerably more extreme than the long-term average monthly minimum, which corresponds to a water surface elevation of 259 feet above NGVD 29 (appendix A, figs. A1-A3). 

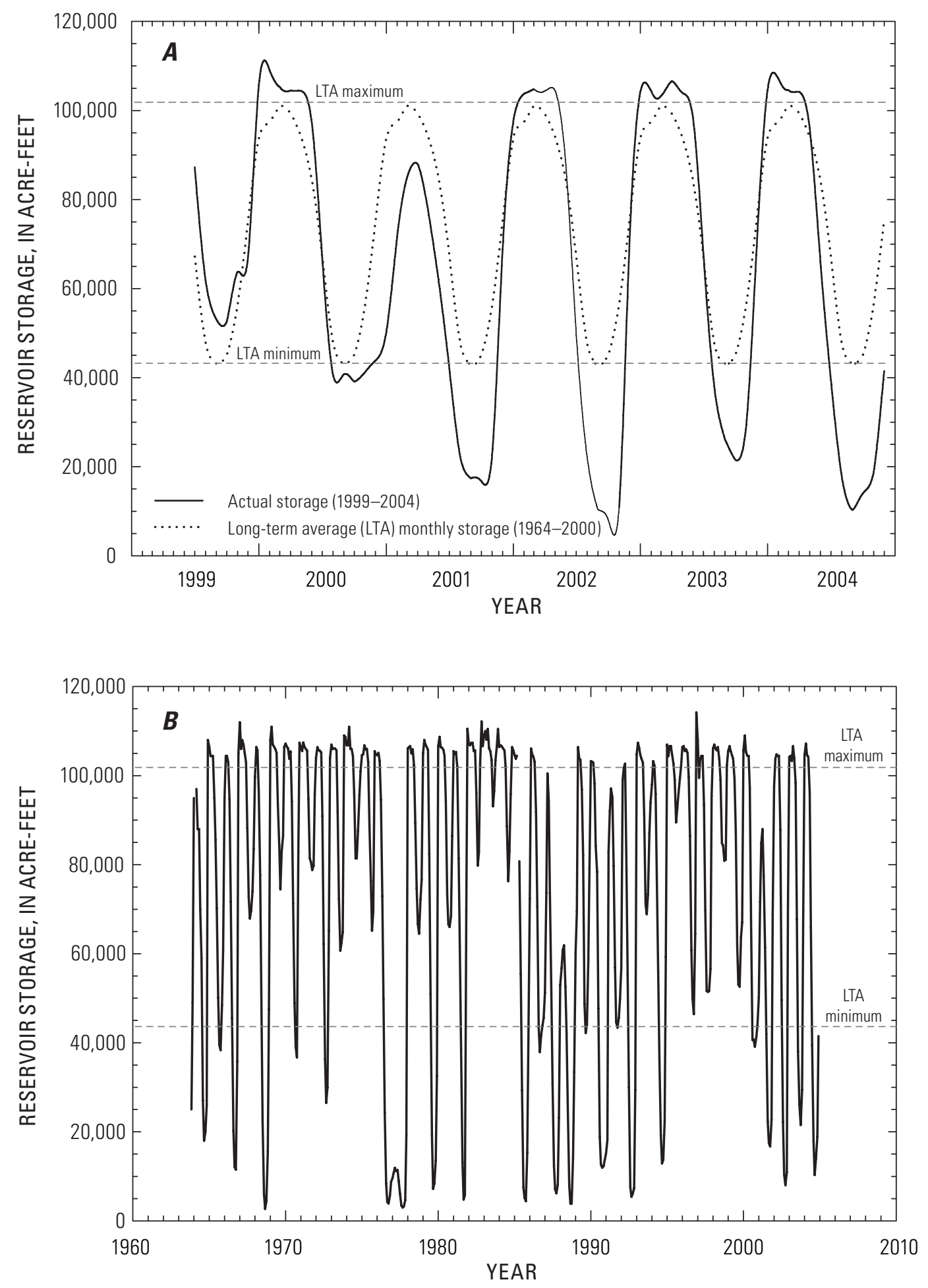

Figure 4. Water storage volume in Camp Far West Reservoir, California: $(A)$ Actual monthly storage for 1999-2004 and long-term monthly average (1964-2000), (B) Monthly data for 1963-2004. 


\section{Study Design}

This report documents the water quality at Camp Far West Reservoir (CFWR) during October 2001 through August 2003. The water-quality sampling was coordinated with parallel sampling of zooplankton (Stewart and others, 2008) and bed sediment. Water-quality analyses of samples collected monthly during the study period from tributaries to Camp Far West Reservoir and the Bear River downstream of the reservoir will be reported separately.

\section{Field Measurement Locations}

To characterize the seasonal behavior of the reservoir with regard to thermal stratification and associated chemical gradients, the parameters temperature, dissolved oxygen (DO), $\mathrm{pH}$, and specific conductance were measured in vertical watercolumn profiles at several locations in CFWR (fig. 5). The main focus of this field effort was at 10 locations along the thalweg (fig. 5, sites 2, 4, 5, and 10-16). Vertical profiles were measured at three or more of these locations on 17 separate occasions during the study (appendix C, tables C1, C2) and, on some occasions, at relatively shallow-water locations near Camp Far West Dam (site 1), in the mid-reservoir area (site 3), and at locations in the Dairy Farm Arm (site 6) and the Rock Creek Arm (sites 7 and 17-20).

\section{Water-Quality Sampling Locations}

The sampling approach was designed to characterize the spatial and seasonal variability of reservoir water quality in terms of chemical and physical properties. The approach also accommodates heterogeneities in the ecological habitats in the water column and the benthos that are caused by extreme seasonal variations in water levels and accommodates known geochemical anomalies, such as the abandoned Dairy Farm Mine on the reservoir's south shore (fig. 5). There is a well-known linkage between sulfate reducing bacteria and methylation of mercury (for example, Compeau and Bartha, 1985; Gilmour and others, 1992). Therefore, one purpose of the BRMCP was to gather information that will be useful in quantifying the contributions of sulfate, iron, and other constituents from Dairy Farm Mine pit lake to CFWR and determining the influence of these constituents on mercury methylation and bioaccumulation in the reservoir and river systems.
Water-quality samples were collected at approximately 3-month intervals (referred to as quarterly samples) during a 2-year period, from fall 2001 through summer 2003, at several locations within CFWR (fig. 5; appendix B, table B1). A summary of the water-quality sampling frequency at the various sampling stations in CFWR is provided in appendix B (table B2). The table also indicates the sampling frequency for water, plankton, fish, invertebrates, and sediment at the sampling stations in conjunction with other components of the Bear River Mercury Cycling Project.

Some of the water-quality stations were sampled at multiple depths (table 1). Three of the quarterly sampling stations are located along the thalweg, the former river channel that represents the deepest water at a given distance from the dam. Water-quality sampling typically was done over a 3-day period, referred to as a sampling event. Water-quality sampling was coordinated closely with zooplankton sampling (Stewart and others, 2008) by collecting both within a 1-2 hour period in the same location. Sediment sampling was done within 1-2 weeks of water-quality sampling at common locations.

The thalweg sampling station near Camp Far West Dam is referred to as the Lower Reservoir, Thalweg (LRT) station (also referred to as site 2 in this report). A second station near Camp Far West Dam was established in shallower water near the northern shoreline of the reservoir. This station, referred to as the Lower Reservoir, Shallow (LRS) station (or site 1), was sampled for water quality during five of the eight quarterly sampling events. During the three other sampling events, a shallow water sample was taken at the LRT station.

In the mid-reservoir area (fig. 5), the thalweg sampling station (Mid-Reservoir, Thalweg, or MRT; site 4) was sampled during all eight quarterly sampling events. A nearby location in shallow water (Mid-Reservoir, Shallow, or MRS; site 3) was sampled on four of the eight quarterly sampling events; as with the lower reservoir stations, a shallow sample was taken at the MRT site during sampling events when the MRS site was not sampled.

The Bear River arm of CFWR receives inflows from the principal tributary to the reservoir, the Bear River (fig. 1). The Bear River Arm (BRA) station (site 5), the third of the thalweg stations (ig. 5 ), was sampled during all eight quarterly sampling events, on some occasions at multiple depths. The Dairy Farm Arm (DFA) station (site 6) is in a small inlet on the southern shoreline of CFWR which receives drainage from the Dairy Farm mine. During periods of extreme drawdown (for example, November 2002), it was not possible to navigate by boat to the previously sampled locations for stations BRA and DFA, so samples were taken closer to the dam. 


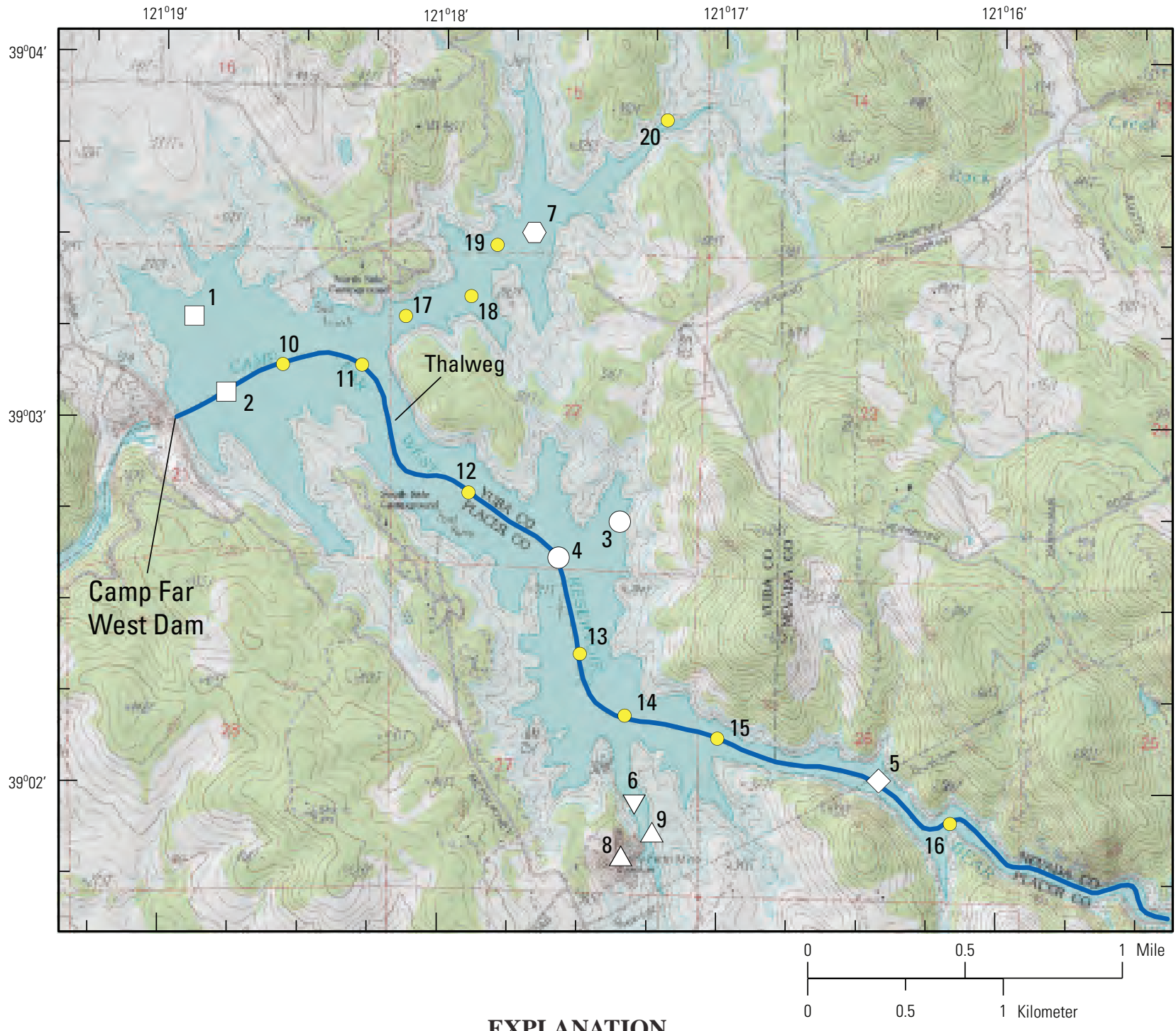

$\begin{array}{lcl}\text { Lower reservoir } & \square^{1} & \text { Lower Reservoir, Shallow (LRS) } \\ & \square^{2} & \text { Lower Reservoir, Thalweg (LRT) } \\ \text { Mid-reservoir } & \bigcirc^{3} & \text { Mid-Reservoir, Shallow (MRS) } \\ & \bigcirc^{4} & \text { Mid-Reservoir, Thalweg (MRT) } \\ \text { Bear River arm } & \triangle^{5} & \text { Bear River Arm (BRA) } \\ \text { Dairy Farm arm } & \nabla^{6} & \text { Dairy Farm Arm (DFA) } \\ \text { Rock Creek arm } & \square^{7} & \text { Rock Creek Arm (RCA) } \\ \begin{array}{lll}\text { Dairy Farm Mine } \\ \text { pit lake and } \\ \text { Impoundments }\end{array} & \triangle^{8} & \begin{array}{l}\text { Dairy Farm Mine Pit Lake (DFP) } \\ \text { Dairy Farm Mine Impoundments (DFI) }\end{array} \\ & 0 & \text { Water-column depth profile locations } \\ \text { (see tables C1 and C2) }\end{array}$

Figure 5. Locations and site numbers for monitoring stations for water-quality monitoring and water-column depth profiles, Camp Far West Reservoir, California. 
Table 1. Data for water-quality parameters measured in the field, Camp Far West Reservoir, California.

[Elevations are relative to sea level in relation to the National Geodetic Vertical Datum of 1929. Sample elevation is the difference between the reservoir elevation and the depth below the reservoir surface. Number in parentheses is the data parameter code, a five-digit code used in the U.S. Geological Survey computerized data system. Thalweg, former river channel (low elevation path). $\mathrm{ft}$ asl, feet above sea level; ${ }^{\circ} \mathrm{C}$, degree Celsius; $\mu \mathrm{S} / \mathrm{cm}$, microsiemens per centimeter; mg/L, milligram per liter; mm Hg, millimeter of mercury; -, not determined]

\begin{tabular}{|c|c|c|c|c|c|c|c|c|c|}
\hline Date & Time & $\begin{array}{c}\text { Depth } \\
\text { (ft) }\end{array}$ & $\begin{array}{c}\text { Reservior } \\
\text { water surface } \\
\text { elevation } \\
\text { (ft asl) }\end{array}$ & $\begin{array}{c}\text { Sample } \\
\text { elevation } \\
\text { (ft asl) }\end{array}$ & $\begin{array}{c}\text { Water } \\
\text { temperature } \\
\left({ }^{\circ} \mathrm{C}\right) \\
(00010)\end{array}$ & $\underset{(00400)}{p H}$ & $\begin{array}{c}\text { Specific } \\
\text { conductance } \\
(\mu \mathrm{S} / \mathrm{cm}) \\
(00905)\end{array}$ & $\begin{array}{c}\text { Dissolved } \\
\text { oxygen } \\
\text { (mg/L) } \\
(00300)\end{array}$ & $\begin{array}{c}\text { Barometric } \\
\text { pressure } \\
\text { (mm Hg) }\end{array}$ \\
\hline
\end{tabular}

Site 1, LRS: Lower Reservoir, Shallow (Camp Far West Reservoir 0.3 mile north of dam abutment) Station number 390317121185001

$\begin{array}{rrrrrrrrrr}10 / 30 / 2001 & 5: 15 \text { PM } & 10 & 224.8 & 214.8 & 17.5 & 7.8 & 146 & 8.2 & - \\ 02 / 12 / 2002 & 12: 00 \text { PM } & 8 & 298.8 & 290.8 & 8.0 & 7.9 & 111 & 13.3 & - \\ 04 / 22 / 2002 & 3: 20 \text { PM } & 10 & 299.9 & 298.9 & 17.0 & 7.3 & 154 & 10.3 \\ 08 / 06 / 2002 & 4: 30 \text { PM } & 10 & 264.0 & 254.0 & 26.0 & 7.9 & 85 & 7.3 \\ 04 / 15 / 2003 & 10: 30 \text { AM } & 40 & 301.4 & 261.4 & 14.0 & 7.8 & 81 & 763 \\ \end{array}$

Site 2, LRT: Lower Reservoir, Thalweg (Camp Far West Reservoir in thalweg near dam near Wheatland)

Station number 390307121183801

$\begin{array}{rrrrrrrrrr}11 / 01 / 2001 & 8: 30 \text { AM } & 70 & 225.2 & 155.2 & 11.3 & 6.7 & 101 & 0.2 & - \\ 02 / 12 / 2002 & 11: 00 \text { AM } & 140 & 298.2 & 158.2 & 7.0 & 7.4 & 93 & 72.3 \\ 04 / 22 / 2002 & 3: 00 \text { PM } & 140 & 299.9 & 159.9 & 9.0 & 6.9 & 155 & 9.6 \\ 08 / 08 / 2002 & 12: 00 \text { PM } & 45 & 262.1 & 217.1 & 21.5 & 6.4 & 74 & 2.0 \\ 08 / 08 / 2002 & 1: 30 \text { PM } & 113 & 262.1 & 149.1 & 10.5 & 7.0 & 89 & 763 \\ 11 / 04 / 2002 & 3: 50 \text { PM } & 10 & 204.0 & 194.0 & 14.2 & 7.1 & 114 & 7.3 \\ 11 / 04 / 2002 & 3: 20 \text { PM } & 55 & 204.0 & 149.0 & 11.0 & 6.5 & 124 & 3.9 & 765 \\ 01 / 29 / 2003 & 2: 30 \text { PM } & 10 & 298.0 & 288.0 & 10.6 & 7.6 & 88 & 12.0 & - \\ 01 / 28 / 2003 & 4: 40 \text { PM } & 140 & 297.5 & 157.5 & 8.1 & 7.3 & 70 & 11.5 & - \\ 04 / 16 / 2003 & 4: 00 \text { PM } & 150 & 300.8 & 150.8 & 9.5 & 7.6 & 75 & 8.0 & 760 \\ 08 / 05 / 2003 & 12: 30 \text { PM } & 1 & 275.1 & 274.1 & 27.5 & 8.4 & 84 & 7.9 & 760 \\ 08 / 05 / 2003 & 3: 30 \text { PM } & 73 & 275.1 & 202.1 & 12.1 & 6.8 & 78 & 5.7 & - \\ 08 / 05 / 2003 & 1: 00 \text { PM } & 120 & 275.1 & 155.1 & 10.9 & 6.9 & 84 & 4.4\end{array}$

Site 3, MRS: Middle Reservoir, Shallow (Camp Far West Reservoir east shoreline 1.6 miles above dam) Station number 390244121171801

$\begin{array}{rrrrrrrrrr}10 / 29 / 2001 & 4: 15 \text { PM } & 6 & 224.6 & 218.6 & 18.0 & 7.8 & 147 & 8.2 & - \\ 02 / 12 / 2002 & 1: 30 \text { PM } & 60 & 298.8 & 238.8 & 7.0 & 7.5 & 94 & 12.1 & - \\ 04 / 22 / 2002 & 1: 50 \text { PM } & 10 & 299.9 & 289.9 & 16.5 & 7.5 & 90 & 14.6 & 760 \\ 04 / 15 / 2003 & 12: 40 \mathrm{PM} & 32 & 301.4 & 269.4 & 15.0 & 7.9 & 81 & 9.6 & 763\end{array}$

Site 4, MRT: Middle Reservoir, Thalweg (Camp Far West Reservoir in thalweg 1.5 miles above dam)

Station number 390238121173101

\begin{tabular}{|c|c|c|c|c|c|c|c|c|c|}
\hline $10 / 29 / 2001$ & 2:45 PM & 50 & 224.6 & 174.6 & 16.5 & 7.4 & 143 & 6.7 & - \\
\hline 02/13/2002 & 8:30 AM & 120 & 299.2 & 179.2 & 7.0 & 7.4 & 93 & 13.5 & 757 \\
\hline $04 / 22 / 2002$ & 12:20 PM & 120 & 299.9 & 179.9 & 9.5 & 7.2 & 154 & 10.0 & 761 \\
\hline 08/07/2002 & 12:10 PM & 10 & 263.0 & 253.0 & 26.0 & 7.8 & 89 & 9.1 & - \\
\hline 08/07/2002 & 12:40 PM & 47 & 263.0 & 216.0 & 19.5 & 6.6 & 72 & 1.6 & - \\
\hline 08/08/2002 & 2:50 PM & 80 & 262.1 & 182.1 & 11.0 & 6.8 & 94 & 0.8 & 767 \\
\hline $11 / 05 / 2002$ & $2: 30 \mathrm{PM}$ & 10 & 204.2 & 194.2 & 14.3 & 6.9 & 127 & 10.3 & 756 \\
\hline $11 / 05 / 2002$ & 2:10 PM & 30 & 204.2 & 174.2 & 13.8 & 6.9 & 134 & 10.5 & 754 \\
\hline 01/29/2003 & 2:00 PM & 10 & 298.0 & 288.0 & 9.8 & 7.4 & 75 & 12.1 & - \\
\hline 01/28/2003 & $3: 30 \mathrm{PM}$ & 120 & 297.5 & 177.5 & 8.2 & 7.4 & 69 & 11.8 & - \\
\hline 04/17/2003 & $10: 30 \mathrm{AM}$ & 125 & 300.6 & 175.6 & 9.7 & 7.8 & 76 & 8.5 & - \\
\hline 08/07/2003 & 11:30 AM & 1 & 273.5 & 272.5 & 26.6 & 7.8 & 84 & 7.7 & - \\
\hline 08/07/2003 & 11:50 AM & 100 & 273.5 & 173.5 & 11.4 & 6.9 & 81 & 4.4 & - \\
\hline
\end{tabular}


Table 1. Data for water-quality parameters measured in the field, Camp Far West Reservoir, California.-Continued

[Elevations are relative to sea level in relation to the National Geodetic Vertical Datum of 1929. Sample elevation is the difference between the reservoir elevation and the depth below the reservoir surface. Number in parentheses is the data parameter code, a five-digit code used in the U.S. Geological Survey computerized data system. Thalweg, former river channel (low elevation path). $\mathrm{ft}$ asl, feet above sea level; ${ }^{\circ} \mathrm{C}$, degree Celsius; $\mu \mathrm{S} / \mathrm{cm}$, microsiemens per centimeter; mg/L, milligram per liter; mm Hg, millimeter of mercury; -, not determined]

\begin{tabular}{|c|c|c|c|c|c|c|c|c|c|}
\hline Date & Time & $\begin{array}{c}\text { Depth } \\
\text { (ft) }\end{array}$ & $\begin{array}{l}\text { Reservior } \\
\text { water surface } \\
\text { elevation } \\
\text { (ft asl) }\end{array}$ & $\begin{array}{l}\text { Sample } \\
\text { elevation } \\
\text { (ft asl) }\end{array}$ & $\begin{array}{c}\text { Water } \\
\text { temperature } \\
\left({ }^{\circ} \mathrm{C}\right) \\
(00010)\end{array}$ & $\begin{array}{c}\mathrm{pH} \\
(00400)\end{array}$ & $\begin{array}{c}\text { Specific } \\
\text { conductance } \\
(\mu \mathrm{S} / \mathrm{cm}) \\
(00905)\end{array}$ & $\begin{array}{c}\text { Dissolved } \\
\text { oxygen } \\
(\mathrm{mg} / \mathrm{L}) \\
(00300)\end{array}$ & $\begin{array}{c}\text { Barometric } \\
\text { pressure } \\
(\mathrm{mm} \mathrm{Hg})\end{array}$ \\
\hline
\end{tabular}

Site 5, BRA: Bear River arm (Camp Far West Reservoir Bear River arm near Wheatland) Station number 390202121162201

$\begin{array}{rrrrrrrrrr}10 / 31 / 2001 & 10: 15 \text { AM } & 12 & 225.0 & 213.0 & 15.5 & 7.3 & 138 & 7.3 & 14.2 \\ 02 / 13 / 2002 & 9: 00 \text { AM } & 80 & 299.2 & 219.2 & 7.0 & 7.5 & 84 & 758 \\ 04 / 22 / 2002 & 10: 40 \text { AM } & 80 & 299.9 & 219.9 & 10.5 & 7.3 & 144 & 4.2 & 756 \\ 08 / 06 / 2002 & 5: 50 \text { PM } & 10 & 264.0 & 254.0 & 26.0 & 7.1 & 88 & 6.5 & 758 \\ 08 / 06 / 2002 & 6: 20 \text { PM } & 55 & 264.0 & 209.0 & 13.0 & 6.6 & 92 & 0.0 & 758 \\ 11 / 05 / 2002 & 4: 10 \text { PM } & 7 & 204.2 & 197.2 & 15.3 & 8.0 & 106 & 12.6 & 756 \\ 01 / 29 / 2003 & 1: 20 \text { PM } & 10 & 298.0 & 288.0 & 9.9 & 7.3 & 72 & 8.5 & - \\ 01 / 28 / 2003 & 2: 50 \text { PM } & 85 & 297.5 & 212.5 & 8.2 & 6.7 & 72 & 7.9 & - \\ 04 / 17 / 2003 & 11: 30 \text { AM } & 90 & 300.6 & 210.6 & 10.0 & 7.5 & 77 & 9.8 & - \\ 08 / 07 / 2003 & 10: 00 \text { AM } & 1 & 273.5 & 272.5 & 26.7 & 7.3 & 88 & 7.2 & - \\ 08 / 06 / 2003 & 3: 00 \text { PM } & 100 & 274.5 & 174.5 & 19.4 & 6.5 & 96 & 0.2 & 763\end{array}$

Site 6, DFA: Dairy Farm arm (Camp Far West Reservoir Dairy Farm arm near Wheatland) Station number 390159121171401

$\begin{array}{rrrrrrrrrr}10 / 31 / 2001 & 1: 00 \text { PM } & 4 & 225.0 & 221.0 & 17.6 & 7.7 & 148 & 8.4 & - \\ 02 / 13 / 2002 & 1: 00 \text { PM } & 20 & 299.2 & 279.2 & 8.5 & 7.7 & 103 & 12.9 & 758 \\ 04 / 23 / 2002 & 12: 10 \text { PM } & 20 & 299.9 & 279.9 & 16.0 & 8.1 & 84 & 10.3 & 759 \\ 08 / 07 / 2002 & 6: 50 \text { PM } & 57 & 263.0 & 206.0 & 17.5 & 6.5 & 76 & 0.5 & - \\ 01 / 30 / 2003 & 3: 30 \text { PM } & 55 & 299.0 & 244.0 & 8.7 & 6.8 & 85 & 10.7 & - \\ 04 / 17 / 2003 & 2: 30 \text { PM } & 55 & 300.6 & 245.6 & 11.1 & 7.4 & 84 & 10.9 & 759 \\ 08 / 07 / 2003 & 4: 00 \text { PM } & 1 & 273.5 & 272.5 & 27.2 & 7.6 & 88 & 7.8 & -\end{array}$

Site 7, RCA: Rock Creek arm (Camp Far West Reservoir Rock Creek arm)

Station number 390331121174101

$\begin{array}{llrlllllll}08 / 07 / 2002 & 03: 40 \text { PM } & 10 & 263.0 & 253.0 & 26.1 & 7.7 & 89 & 8.5 & - \\ 04 / 17 / 2003 & 01: 20 \text { PM } & 80 & 300.6 & 220.6 & 10.5 & 7.6 & 79 & 10.0 & 761 \\ 08 / 07 / 2003 & 01: 00 \text { PM } & 1 & 273.5 & 272.5 & 27.5 & 7.9 & 85 & 7.8 & - \\ 08 / 07 / 2003 & 01: 30 \text { PM } & 40 & 273.5 & 233.5 & 26.4 & 7.1 & 89 & 4.5 & -\end{array}$

Site 8, DFP: Dairy Farm Mine Pit Lake (Dairy Farm Mine pit lake near Wheatland)

Station number 390148121171701

$\begin{array}{rrrrrrrrrr}10 / 31 / 2001 & 2: 15 \text { PM } & 1 & 225.0 & 224.0 & 11.3 & 3.0 & 1,380 & 9.2 & 3.7 \\ 02 / 13 / 2002 & 3: 10 \text { PM } & 10 & 299.2 & 289.2 & 8.5 & 7.7 & 103 & 755 \\ 02 / 13 / 2002 & 3: 30 \text { PM } & 35 & 299.2 & 264.2 & 8.0 & 6.9 & 105 & 1.1 \\ 04 / 24 / 2002 & 11: 10 \text { AM } & 30 & 300.0 & 270.0 & 11.0 & 7.7 & 108 & 9.2 \\ 08 / 07 / 2002 & 5: 00 \text { PM } & 0.5 & 263.0 & 263.0 & 26.0 & 4.0 & 274 & 9.0 & 755 \\ 11 / 05 / 2002 & 2: 50 \text { PM } & 1 & 204.2 & 204.2 & - & 3.1 & 900 & - \\ 01 / 30 / 2003 & 12: 30 \text { PM } & 10 & 299.0 & 289.0 & 11.0 & 6.5 & 85 & 8.7 & - \\ 01 / 30 / 2003 & 1: 20 \text { PM } & 38 & 299.0 & 261.0 & 9.2 & 4.6 & 203 & 10.2 & - \\ 04 / 17 / 2003 & 4: 00 \text { PM } & 40 & 300.6 & 260.6 & 10.5 & 5.0 & 165 & 7.8 & 759 \\ 08 / 07 / 2003 & 4: 30 \text { PM } & 1 & 273.5 & 272.5 & 24.0 & 6.5 & 125 & 8.7\end{array}$

Site 9, DFI: Dairy Farm Mine Impoundments (Camp Far West Reservoir impoundment Dairy Farm Mine arm) Station number 390152121171001

\begin{tabular}{rrrrrrrrrr}
$10 / 31 / 2001$ & $2: 40$ PM & 0.5 & 225.0 & 224.5 & 17.1 & 5.0 & 792 & 9.0 & - \\
$02 / 13 / 2002$ & $2: 20$ PM & 52 & 299.2 & 247.2 & 8.0 & 7.1 & 105 & 11.8 & 755 \\
$04 / 23 / 2002$ & $1: 10$ PM & 20 & 299.9 & 279.9 & 16.0 & 8.0 & 84 & 10.0 & 759 \\
$11 / 05 / 2002$ & $2: 00$ PM & 0.5 & 204.2 & 204.2 & - & 3.9 & 1,660 & - & - \\
\hline
\end{tabular}


The Dairy Farm Mine pit lake (station DFP, site 8), located on the southern shore of CFWR (ig. 5 ), is isolated from the reservoir during low stage but is connected with the reservoir during high stage. Water-quality samples were collected at the DFP station during each of the eight quarterly sampling events. During high stage, when boat access was possible, water-quality samples were collected from multiple depths. During low stage, grab samples were collected from the shore of the pit lake. During some of the sampling events, grab samples also were collected from impoundments near the Dairy Farm Mine (station DFI; site 9), which are isolated when the reservoir is at low stage.

The Rock Creek Arm (RCA) station (site 7) is located in the northeastern part of CFWR (fig. 5). Rock Creek is a relatively minor tributary with a small drainage area. Although this location was not originally chosen for intensive sample collection, it became one of three principal sites for sampling invertebrates and fish, because insufficient habitat was found at the Mid-Reservoir, Shallow site. Water samples were taken from the RCA station during three of the eight quarterly sampling events (appendix A, table A2).

\section{Field Methods, Sample Collection, and Processing}

A multi-probe sonde (YSI model 600 XLM) was used to measure vertical profiles of temperature, $\mathrm{pH}$, dissolved oxygen (DO), and specific conductance in the water column. Initially measurements were made at 5 -foot intervals; then measurements were made at 1-foot intervals in parts of the profile where results varied most. The sonde was calibrated according to the specifications of the manufacturer. During the study, the sonde was returned to the manufacturer once for routine factory maintenance.

Specialized cleaning and sampling techniques were used during all stages of collection of discrete water samples to minimize sample contamination. Prior to use, all containers and equipment used for water and sediment sampling were cleaned using a dilute liquid soap followed by a 5-percent hydrochloric acid solution and multiple rinses in ultrapure, deionized (DI) water (18 M $\Omega$-cm [megaohm-centimeter]), following standard USGS protocols (Shelton, 1994).

Water samples were pumped from discrete depths using a peristaltic pump attached to a Teflon ${ }^{\circledR}$ tubing line. After collection in containers made of Teflon ${ }^{\circledR}$ or lined with fluorinated plastic that is similar to Teflon ${ }^{\circledR}$ in its wetting and cleaning properties, the water samples were transferred to a Teflon $^{\circledR}$-lined churn for splitting. Water samples collected for analysis of suspended solids concentration (SSC) were taken from the churn and collected in pre-weighed 1-L Nalgene bottles. In contrast to all other splits, the bottles for SSC samples were not rinsed with the ambient water, to avoid introducing extraneous suspended solids to the container. The SSC samples were chilled on wet ice or refrigerated at $5{ }^{\circ} \mathrm{C}$ until analysis.

Discrete water samples collected from specific depths in the reservoir were analyzed for six types of mercury:

(1) total mercury $\left(\mathrm{Hg}_{\mathrm{T}}\right)$ in unfiltered water, (2) $\mathrm{Hg}_{\mathrm{T}}$ in filtered water, (3) particulate $\mathrm{Hg}_{\mathrm{T}}$, (4) monomethylmercury (MeHg) in unfiltered water, (5) MeHg in filtered water, and (6) particulate MeHg. (For the remainder of this report, the term methylmercury [also abbreviated as $\mathrm{MeHg}$ ] is used instead of "monomethylmercury"; note that other methylated forms of mercury such as dimethylmercury may be present but are not included in reported methylmercury analyses.) Analyses of $\mathrm{Hg}_{\mathrm{T}}$ in water for this study were done by two laboratories: the USGS National Research Program laboratory in Boulder, Colorado (referred to as the Boulder lab) and the USGS Wisconsin Mercury Research Laboratory (WMRL) in Middleton, Wisconsin (referred to as the Wisconsin lab). An extensive laboratory intercomparison was performed on split samples for this project and two other concurrent projects, as discussed in section, "Quality Assurance and Quality Control" of this report. All analyses of MeHg in water for this study were done by the USGS Wisconsin lab.

Two different procedures were used to filter the water samples. A Gelman Sciences polysulfone, tortuous-path capsule filter of $0.45-\mu \mathrm{m}$ nominal pore size (model 12175) was used for most constituents. On selected samples for analysis of $\mathrm{Hg}_{\mathrm{T}}$ and $\mathrm{MeHg}$, a quartz fiber filter (QFF) of nominal $0.7-\mu \mathrm{m}$ pore size was used. Particulate $\mathrm{Hg}_{\mathrm{T}}$ and $\mathrm{MeHg}$ were determined directly using the material trapped by the QFFs. These QFF particulate concentrations were compared with the differences in concentration between unfiltered samples and filtered samples (Gelman capsule filter), as described in section “Quality Assurance and Quality Control”).

Alkalinity (a proxy for dissolved bicarbonate) was analyzed by titration in the laboratory on a filtered subsample (stored chilled in darkness until analysis), usually within 48 hours of collection. Major cations (calcium, iron, magnesium, potassium, silica, and sodium) and more than 40 trace elements were analyzed in filtered and unfiltered samples by the USGS Boulder lab. Major anions (sulfate and chloride in filtered samples only) also were analyzed by the USGS Boulder lab. Nutrients in filtered and unfiltered samples were analyzed by the USGS National Water Quality Laboratory (NWQL) in Denver, Colorado. Forms of nitrogen $(\mathrm{N})$ that were analyzed included ammonia plus organic $\mathrm{N}$ in both unfiltered and filtered water, and the following three forms of $\mathrm{N}$ in filtered water only: ammonia, nitrite, and nitrite plus nitrate. Forms of phosphorus (P) that were analyzed included total $P$ in both unfiltered and filtered water, and orthophosphate in filtered water only. Organic carbon in filtered and particulate form was analyzed by the USGS NWQL. The USGS laboratory in Marina, California, determined concentration of suspended solids in water 
samples along with the percentage of fine material $(<0.063$ $\mathrm{mm}$ diameter) in the suspended solids. These quantities were combined to compute the concentration of suspended silt and clay. The terms "suspended solids" and "suspended sediment" are used interchangeably in this report. The procedure used by the USGS Marina laboratory did not include oxidations of the samples of suspended solids (for example using hydrogen peroxide, as in Poppe and others, 2000) to remove organic matter; therefore, the material that was measured is best described as "suspended solids" rather than the term "suspended sediment," which is often reserved to refer to residual inorganic material after organic material has been removed. Nevertheless, the results from the Marina lab appear in USGS databases as parameter code 80154, which is identified as "suspended sediment."

Filtered and unfiltered water samples for analysis of $\mathrm{Hg}_{\mathrm{T}}$ by the USGS Boulder lab were stored in acid-washed glass bottles provided by the laboratory and were preserved using a potassium dichromate-nitric acid solution. Filtered and unfiltered water samples for analysis of $\mathrm{Hg}_{\mathrm{T}}$ and (or) $\mathrm{MeHg}$ by the Wisconsin lab were stored in acid-washed Teflon ${ }^{\circledR}$ bottles and preserved with a distilled (sub-boiling) 50-percent hydrochloric acid solution, all provided by the laboratory. Filtered and unfiltered samples for analysis of major cations and trace elements were stored in acid-washed high-density polyethylene (HDPE) bottles and preserved using distilled, nitric acid provided by the Boulder lab.

Filtered samples collected for analysis of anions were chilled on wet ice and then refrigerated at less than $5^{\circ} \mathrm{C}$ until analysis. Unfiltered samples collected for analysis of nutrients were preserved using a sulfuric acid solution and then chilled on wet ice followed by refrigeration; filtered nutrient samples were not acidified but were chilled until analyzed. Samples collected for analysis of stable isotopes of hydrogen and oxygen in water were stored in glass bottles with polyseal caps with minimal headspace to minimize evaporation. Aqueous sulfate was precipitated from filtered water samples at $90^{\circ} \mathrm{C}$ using a barium chloride solution after using $\mathrm{HCl}$ to lower the $\mathrm{pH}$ value to about 2; the resulting barium sulfate precipitate was filtered using $0.7-\mu \mathrm{m}$ pore diameter filters and then transferred to silver-foil trays.

Laboratory data for aqueous concentrations are reported in units of mass per volume. Typical units for constituents appearing in data tables in this report are milligrams per liter $(\mathrm{mg} / \mathrm{L})$, micrograms per liter $(\mu \mathrm{g} / \mathrm{L})$ and nanograms per liter (ng/L). Some constituents are plotted using molar units to facilitate a more direct comparison of constituents. Converting concentration data from milligrams per liter $(\mathrm{mg} / \mathrm{L})$ to micromoles per liter $(\mu \mathrm{mol} / \mathrm{L})$ is by the formula $1,000 *(\mathrm{mg} / \mathrm{L}) /$ $\mathrm{MW}=\mu \mathrm{mol} / \mathrm{L}$, where $\mathrm{MW}$ is the molecular weight of the constituent in grams per mole $(\mathrm{g} / \mathrm{mol})$. Constituents plotted using molar units (and corresponding chemical symbol and value of MW, in $\mathrm{g} / \mathrm{mol}$ ) are as follows: calcium (Ca, 40.078), chloride (Cl, 35.453), nitrogen (N, 14.0067), phosphorus (P, 30.97376), sodium ( $\mathrm{Na}, 22.98977)$, and sulfate $\left(\mathrm{SO}_{4}, 96.0626\right)$.

\section{Laboratory Methods}

For USGS-approved methods used for routine analyses by laboratories such as the USGS NWQL, relatively little method information is given in this report, and the reader is referred to published sources. More detailed information is given in this section for research methods that have not been officially approved by the USGS.

Analysis of total mercury $\left(\mathrm{Hg}_{\mathrm{T}}\right)$ in water by the USGS Boulder lab was done using cold-vapor atomic fluorescence spectrometry (CVAFS). Mercury stock and standard solutions were made from 99.9995 percent mercuric chloride $\left(\mathrm{HgCl}_{2}\right)$ salt and preserved in a solution of high-purity nitric acid and primary-standard grade potassium dichromate using the same reagents and concentrations as those used to preserve samples. Deionized water (type 1, $18 \mathrm{M} \Omega-\mathrm{cm}$ ) was used for preparing all standards and reagent solutions. A solution of 3-percent hydrochloric acid (volume:volume, hydrochloric acid:type 1 , $18 \mathrm{M} \Omega$-cm DI water) was used to prepare a 2-percent stannous chloride $\left(\mathrm{SnCl}_{2}\right)$ solution (wt:volume, stannous chloride:3percent hydrochloric acid), which was used to reduce mercury to its elemental form in the cold vapor reactor. The vapor was transported to the detector with a stream of argon gas. Trace concentration levels of mercury were measured using an automated, cold-vapor atomic-fluorescence spectrometer or CVAFS (PS Analytical) using methods described previously (Roth, 1994; D.A. Roth, U.S. Geological Survey, written commun., 1999). Instrument parameters for the CVAFS mercury analysis were the same as those described by Alpers and others (2000). Peak-height intensities of unknown samples were compared to a six-point calibration curve prepared from aqueous standards ranging in concentration from 0 to $50 \mathrm{ng} / \mathrm{L}$.

Analysis of $\mathrm{Hg}_{\mathrm{T}}$ in unfiltered and filtered water by the USGS Wisconsin lab was done using procedures described by Olson and De Wild (1999), approved as USGS production methods. Methylmercury $(\mathrm{MeHg})$ in water was analyzed at the Wisconsin lab using ethylation-distillation CVAFS methods with double amalgamation, as described by Olson and De Wild (1999) and De Wild and others (2002). Analysis of MeHg in water by the WMRL was approved by the USGS Branch of Quality Assurance as a production method in August 2002 after some of the analyses for this report were completed. The method used by the Wisconsin lab to analyze $\mathrm{MeHg}$ in water samples in this study prior to the date of method approval was identical to the USGS-approved method. Therefore, MeHg data collected throughout the study period are expected to be of consistent quality, despite the change in the approval status of the method.

Major cations and trace metals in water were analyzed by inductively coupled plasma (ICP) methods: both atomic emission spectrometry (AES) and mass spectrometry (MS) were used. Major elements, including calcium (Ca), iron (Fe), magnesium $(\mathrm{Mg})$, potassium $(\mathrm{K})$, sodium $(\mathrm{Na})$, and silica $(\mathrm{Si}$, reported as $\mathrm{SiO}_{2}$ ), were determined by ICP-AES techniques using a Perkin-Elmer Optima 3300DV multi-channel emission 
spectrometer. Use of the dual-view (radial and axial) optical configuration provided optimal sensitivity for various elements regardless of concentration. A description of the analysis conditions and procedures is reported by Garbarino and Taylor (1996). Details of the operational conditions are described by Mitko and Bebek (1999, 2000). Except for mercury, trace-element determinations were done by ICP-MS using a Perkin-Elmer Elan Model 6000. Aerosols of acidified aqueous samples were introduced into the spectrometer with a cone-spray pneumatic nebulizer. Multiple internal standards (indium [In], iridium [Ir], and rhodium [Rh]), which spanned the mass range, were used to normalize the system for drift. Details of the specific analysis techniques, procedures, and instrumental settings are described by Garbarino and Taylor (1996) and Taylor (2001). Major anions in filtered water (chloride and sulfate) were analyzed by ion chromatography following procedures described by Fishman and Friedman (1989).

Nutrients in each water sample were analyzed for three forms of phosphorus (P) and five forms of nitrogen $(\mathrm{N})$, as described below. The three types of phosphorus analyses included orthophosphate in filtered water, plus total phosphorus in unfiltered and filtered water. Orthophosphate was determined using an automated, colorimetric, phosphomolybdate-blue procedure, with antimony (Sb) added to increase the reduction rate (Patton and Truitt, 1992; Fishman, 1993). Total phosphorus was determined colorimetrically as orthophosphate after Kjeldahl digestion (Patton and Truitt, 1992). The five types of nitrogen analyses included the following forms in filtered water only: (1) nitrite $\left(\mathrm{NO}_{2}^{-}\right)$, (2) nitrite plus nitrate $\left(\mathrm{NO}_{3}^{-}\right)$, and (3) ammonia $\left(\mathrm{NH}_{3}\right)$, as well as ammonia plus organic nitrogen, which was analyzed in filtered and unfiltered water. The method used to analyze nitrite was diazotization using sulfanilamide and N-1-naphthylethylenediamine under acidic conditions to form a red compound, the absorbance of which was determined colorimetrically using an automated-segment flow procedure (Fishman, 1993). The concentration of nitrite plus nitrate was determined by reducing nitrate to nitrite using cadmium metal; the nitrite was then analyzed by diazotization (Fishman, 1993). Ammonia was analyzed using a alicylatehypochlorite method, in the presence of ferricyanide ions, that produces the salicylic acid analog of indophenol blue, which was analyzed colorimetrically using an automated-segment flow procedure (Fishman, 1993). The concentration of ammonia plus organic nitrogen in unfiltered and filtered samples was determined using the same Kjeldahl digestion as that used for total phosphorus, in which the organic nitrogen is reduced to the ammonium ion, followed by determination of the ammonium ion concentration by the colorimetric salicylate-hypochlorite method (Fishman and Friedman, 1989; Patton and Truitt, 1992).

Concentrations of dissolved organic carbon (DOC) were determined in $100-\mathrm{mL}$ filtered water samples $(0.45-\mu \mathrm{m}$ silver membrane filter). The filtrates were acidified before analysis to remove dissolved and colloidal carbonates and bicarbonates while mitigating the effects of humic-substance precipitation. Then the organic carbon was oxidized to carbon dioxide by adding persulfate and exposing the samples to ultraviolet light. The carbon dioxide was then measured by infrared spectrometry using a Dorhmann carbon analyzer (Brenton and Arnett, 1993). Particulate organic carbon (POC) concentrations were determined in the residual material that was collected on the silver membrane filters used to prepare DOC samples. The silver membrane filters were treated with acid to dissolve inorganic forms of carbon, then were reacted with potassium persulfate in glass ampules for 4 hours at 116 to $130^{\circ} \mathrm{C}$. The ampules then were broken in the carbon analyzer, releasing carbon dioxide, which was measured by infrared spectrometry using an Oceanography International carbon analyzer (Wershaw and others, 1987).

Stable isotope ratios of hydrogen $\left({ }^{2} \mathrm{H} /{ }^{1} \mathrm{H}\right.$, where ${ }^{2} \mathrm{H}$ is deuterium or $\mathrm{D}$ ) and oxygen $\left({ }^{18} \mathrm{O} /{ }^{16} \mathrm{O}\right)$ in water were determined using standard methods by the laboratory in the Department of Geology at the University of California, Davis under the direction of Howard Spero. Oxygen isotope ratios in water, expressed as $\delta^{18} \mathrm{O}_{\mathrm{H} 2 \mathrm{O}}$ in units of permil (parts per thousand, or \%o) relative to Vienna Standard Mean Ocean Water (VSMOW), were determined by conventional mass spectrometer after equilibration with carbon dioxide, a modification of the technique of Epstein and Mayeda (1953). Hydrogen isotope ratios, expressed as $\delta \mathrm{D}$ in units of permil relative to VSMOW, were determined by conventional mass spectrometer by the zinc shot technique (Coleman and others, 1982). Three working standards calibrated to VSMOW and other standard reference waters supplied by the International Atomic Energy Agency (IAEA) were analyzed in duplicate with each batch of water samples analyzed. Analytical uncertainty was \pm 0.05 permil for $\delta^{18} \mathrm{O}_{\mathrm{H} 2 \mathrm{O}}$ and \pm 1.0 permil for $\delta \mathrm{D}$.

Stable isotope ratios of sulfur $\left({ }^{34} \mathrm{~S} /{ }^{32} \mathrm{~S}\right)$ and oxygen $\left({ }^{18} \mathrm{O} /{ }^{16} \mathrm{O}\right)$ in aqueous sulfate were analyzed at the USGS laboratory in Denver, Colorado, under the direction of Robert O. Rye using continuous flow mass spectrometer techniques (Fry and others, 1992; Kester and others, 2001). Sulfur isotopes in aqueous sulfate are expressed as $\delta^{34} \mathrm{~S}_{\mathrm{SO} 4}$ and are reported relative to the Cañon Diablo Troilite (CDT). Oxygen isotopes in aqueous sulfate are expressed as $\delta^{18} \mathrm{O}_{\mathrm{SO} 4}$ and are reported relative to VSMOW. Analytical uncertainty was \pm 0.2 permil for $\delta^{34} \mathrm{~S}_{\mathrm{SO} 4}$ and \pm 0.5 permil for $\delta^{18} \mathrm{O}_{\mathrm{SO} 4}$.

\section{Statistical Methods}

A large proportion of the measured concentrations of methylmercury (MeHg), especially those in filtered water, were below the method detection limit (MDL) of $0.04 \mathrm{ng} / \mathrm{L}$. Results below the MDL are referred to as non-detects or censored data. Procedures for computing statistics of data sets with a large proportion of non-detects are described in detail by Helsel (2005). For constituents with less than 50 percent 
non-detects, a parametric procedure known as the KaplanMeier approach is recommended. Determining the median value of such data sets is straightforward, and if it is assumed that the data fit a lognormal distribution, this distribution can be used to estimate values for the mean, standard error, and other characteristic values such as the 25th percentile value. For data sets with 50 to 80 percent non-detects and a total of less than 50 detected values, Helsel (2005) recommends either of two procedures: a parametric procedure known as Maximum Likelihood Estimation (MLE) or a non-parametric procedure known as Regression on Order Statistics (ROS).

Results for MeHg in unfiltered water and the ratio of $\mathrm{MeHg}$ to total mercury $\left(\mathrm{MeHg} / \mathrm{Hg}_{\mathrm{T}}\right.$ ) in unfiltered water were in the category of less than 50 percent non-detects, whereas results for $\mathrm{MeHg}$ and $\mathrm{MeHg} / \mathrm{Hg}_{\mathrm{T}}$ in filtered water were in the 50 to 80 percent non-detect category. Statistical properties of the unfiltered $\mathrm{MeHg}$ data were evaluated using both the Kaplan-Meier and the ROS approaches, with similar results. The statistical software program MINITAB (MiniTab, Inc., State College, Penn.) was used with the macro CROS (Helsel, 2005) for this analysis. Only the ROS approach could be used for the filtered MeHg data. For consistency among all the MeHg data (unfiltered and filtered), statistical results are reported using the ROS approach for all MeHg constituents, including values of $\mathrm{MeHg} / \mathrm{Hg}_{\mathrm{T}}$.

Other statistical quantities were computed to characterize the variability (or precision) of laboratory data. To evaluate the variability among replicate samples, the relative percentage difference (RPD) was computed as the absolute value of the difference between reported values divided by the average of the reported values, multiplied by 100 percent. To evaluate the variability among data representing multiple analytical observations of the same sample, the relative standard deviation (RSD) was computed as the standard deviation of three or more analyses divided by the average of the measurements, multiplied by 100 percent.

Results below the MDL are represented on scatter plots by plotting points at one-half the MDL with an error bar extending from the MDL to the axis. In these situations, the value of one-half of the MDL is not intended to represent an estimate of the concentration for these samples, but rather is used so that identifying characteristics of the sample, such as location and season of collection, can be displayed in a manner similar to other samples with detected concentration values.

\section{Quality Assurance and Quality Control}

A variety of measurements and analyses were used to determine the quality of the data generated in this study (appendixes E and $\underline{\mathrm{F}}$ ). The quality-assurance (QA) program consisted of quality-control (QC) measures including field and laboratory blanks, standard reference materials (SRM) where available, spike recoveries, and replicate samples. Qualitycontrol measures used during analysis of $\mathrm{MeHg}$ in water were described by De Wild and others (2002). Water samples were analyzed in batches of 11 samples plus three laboratory blanks, a matrix spike, and a matrix spike duplicate. The reported values for MeHg concentrations were corrected for daily blank values, as described by De Wild and others (2002).

\section{Detection Limits}

The method for total mercury $\left(\mathrm{Hg}_{\mathrm{T}}\right)$ used by the USGS Boulder lab had a method detection limit (MDL) of $0.4 \mathrm{ng} / \mathrm{L}$, whereas the USGS Wisconsin lab's method had an MDL for $\mathrm{Hg}_{\mathrm{T}}$ of $0.04 \mathrm{ng} / \mathrm{L}$, one order of magnitude lower. The concentrations of $\mathrm{Hg}_{\mathrm{T}}$ detected in all environmental samples collected for this study were above the MDL for the Wisconsin lab: however, the $\mathrm{Hg}_{\mathrm{T}}$ concentrations in some of the filtered samples were below the MDL for the Boulder lab. The MDL for MeHg in water at the USGS Wisconsin lab, defined using standard protocol (U.S. Environmental Protection Agency, 1990), was $0.025 \mathrm{ng} / \mathrm{L}$ during $1999-2000$ and $0.04 \mathrm{ng} / \mathrm{L}$ during 2001-03. A conservative MDL for MeHg of $0.04 \mathrm{ng} / \mathrm{L}$ is used throughout this report.

Major and trace elements in water were analyzed by inductively coupled plasma (ICP) methods; each analysis consisted of at least four replicate instrumental measurements. Each filtered and unfiltered sample was collected in duplicate and analyzed in triplicate. The triplicate analyses were analyzed statistically and the analyses were accepted if the standard deviation was within standard tolerances of precision (generally less than 15 percent of the amount present). The error tolerance is increased for analyses close to the detection limit for a given analyte. Median detection limits for trace elements and selected major elements analyzed by ICP methods are given in appendix E (table E11).

\section{Blanks}

Data for $\mathrm{Hg}_{\mathrm{T}}$ in unfiltered and filtered blanks are given in appendix E (tables E1 and E2), respectively, for analyses by the USGS Boulder lab and in tables E3 and E4, respectively, for analyses by the USGS Wisconsin lab. To present the most realistic indication of possible $\mathrm{Hg}_{\mathrm{T}}$ contamination, tables E1E4 include data for all blanks submitted to the respective laboratories by the USGS California Water Science Center during the period when samples were analyzed for this study, including blanks collected at some field sites outside Camp Far West Reservoir using similar equipment and techniques.

Several purified water sources were used for $\mathrm{Hg}_{\mathrm{T}}$ blanks, including a MilliQ purification system at the USGS laboratory in Sacramento, California, an in-house deionization system in Sacramento capable of preparing ASTM Class 1 deionized water, a polished water system in Sacramento designed to produce organic-free water, and the deionized water system at the USGS Wisconsin lab. The $\mathrm{Hg}_{\mathrm{T}}$ concentration in the source-blank waters ranged from below the Wisconsin lab's method detection limit (less than $0.04 \mathrm{ng} / \mathrm{L}$ )(table E3) to 
$2.5 \mathrm{ng} / \mathrm{L}$ (table E1). Because the MilliQ and the polished water systems produced unexpectedly high $\mathrm{Hg}_{\mathrm{T}}$ concentrations (2.3 and $2.5 \mathrm{ng} / \mathrm{L}$, respectively) early in the study (October 2001 to January 2002), deionized water from the USGS Trace Metals Laboratory in Sacramento and the USGS Wisconsin lab were used for the remainder of the study, resulting in source blank $\mathrm{Hg}_{\mathrm{T}}$ concentrations less than $1.0 \mathrm{ng} / \mathrm{L}$ (tables E1, E3).

To determine the central tendency of $\mathrm{Hg}_{\mathrm{T}}$ concentrations in blanks, median values and upper confidence limits were calculated separately for filtered and unfiltered blanks using the Kaplan-Meier method (Helsel, 2005). This approach, as implemented in the USGS library of S-Plus, was used to determine the cumulative probability distribution from ranked data and to estimate summary statistics. The method was selected because it is non-parametric (that is, it does not assume normally distributed data) and because it can incorporate censored data with multiple detection limits. For the unfiltered blanks (tables E1, E3), the median concentration of $\mathrm{Hg}_{\mathrm{T}}$ was $0.11 \mathrm{ng} / \mathrm{L}$ and the upper 95-percent confidence level was $0.32 \mathrm{ng} / \mathrm{L}$. For the filtered blanks (tables E2, E4), the median concentration of $\mathrm{Hg}_{\mathrm{T}}$ was $0.08 \mathrm{ng} / \mathrm{L}$ and the upper 95 -percent confidence level was $0.14 \mathrm{ng} / \mathrm{L}$. In addition, percentiles for the $\mathrm{Hg}_{\mathrm{T}}$ blank data were calculated using the binomial distribution applied to ranked data. For the unfiltered data (tables E1, E3), the 90th percentile with a 90-percent confidence level was $0.94 \mathrm{ng} / \mathrm{L}$, a value less than the minimum $\mathrm{Hg}_{\mathrm{T}}$ concentration $(1.0 \mathrm{ng} / \mathrm{L})$ detected in environmental samples. For the filtered blanks (tables E2, E4), the 90th percentile at an 88-percent confidence level was $0.88 \mathrm{ng} / \mathrm{L}$. In comparison, the median values for all unfiltered and filtered $\mathrm{Hg}_{\mathrm{T}}$ in environmental samples analyzed in this study were 4.3 and $0.9 \mathrm{ng} / \mathrm{L}$, respectively. The 25th percentile value for $\mathrm{Hg}_{\mathrm{T}}$ in filtered environmental samples for this study was $0.4 \mathrm{ng} / \mathrm{L}$.

Thus, some of the filtered blank values for $\mathrm{Hg}_{\mathrm{T}}$ are in the same concentration range as the values for some of the filtered environmental samples. In some cases, the elevated blank results correspond to elevated $\mathrm{Hg}_{\mathrm{T}}$ in blank water sources. The standard procedure of rinsing sampling equipment and sample bottles with the ambient water reduces potential $\mathrm{Hg}_{\mathrm{T}}$ contamination from deionized water used to clean equipment. Nevertheless, low-level values for $\mathrm{Hg}_{\mathrm{T}}$ in filtered environmental samples must be interpreted with due caution.

Concentrations of MeHg in unfiltered and filtered blanks analyzed at the USGS Wisconsin lab during this study are given in tables E5 and E6, respectively. Source water for MeHg blanks was provided by the USGS Wisconsin lab. Methylmercury concentrations in all source blanks, equipment blanks, and process blanks analyzed during the study period were below the MDL (0.04 ng/L).

Concentration values for trace metals and major elements in blanks are given in table E7 (unfiltered: equipment blanks, preservation acid blanks, and source blanks) and table E8 (filtered: process blanks and filter blanks). Results for trace elements in blanks (tables E7 and E8) generally were near or below method detection limits (table E11). Data for anion blanks are given in table E9. Data for blanks for nutrients and organic carbon are shown in table E10. Values for anion, nutrients, and organic carbon blanks were uniformly low, indicating high data quality.

\section{Standard Reference Materials}

When each batch of samples was analyzed by ICP for trace element and major cations, several standard reference materials (SRM) also were analyzed as part of the QA program. A similar procedure was used with each batch of samples analyzed for mercury by CVAFS at the USGS Boulder lab. Plots of reported values in relation to observed values for certified SRM, USGS standard reference water samples (SRWS), and specific rare-earth element reference materials (PPREE1 and SCREE1; Verplanck and others, 2001) are shown in appendix F (figs. F1-F7). For nearly all elements considered, the SRMs span ranges of concentrations comparable to the ranges of concentrations for environmental samples in this study. The number of times each standard was analyzed during 2001-03 is indicated in the explanation of each figure; the standards typically were analyzed several hundred times during the study period. There is excellent agreement between all reported and observed values for the standards. Regression correlation coefficients were derived from correlation plots of observed and reported values for the analysis of standard reference materials for 21 selected trace elements (table E12); these coefficients ranged from a minimum of 0.9969 for selenium to a maximum of 1.000 for eight trace elements (beryllium, cadmium, cobalt, copper, lead, manganese, molybdenum, and strontium).

\section{Spiked Blanks and Spiked Samples}

Data for spiked blanks for the elements arsenic, cadmium, copper, lead, and zinc for analyses made during 2002-04 are given in appendix F (fig. F8). In nearly all cases, spike recoveries were within the control range of 80 to 120 percent of the expected amount. Data for spiked blanks having an expected $\mathrm{Hg}_{\mathrm{T}}$ concentration of $5 \mathrm{ng} / \mathrm{L}$ (fig. F9) indicate that nearly all results fell within the control range of 80 to 120 percent recovery. Field samples were spiked at levels generally three to ten times the ambient concentration of each element. Results for spiked field samples for the same five trace elements as were used for the spiked blanks (fig. F10) and for mercury (fig. F11) indicate again that nearly all spike recoveries were within the control range of 80 to 120 percent of the expected value. 


\section{Replicate Analyses}

Split samples for analysis of trace elements and total mercury by the USGS Boulder lab were collected in pairs of bottles designated as split replicates " 1 of 2 " and " 2 of 2." Because replicate split samples were routinely analyzed as separate unknowns and each replicate was analyzed in triplicate, plots of replicate 1 versus replicate 2 indicate analytical precision and variability in the sampling-splitting procedure as well as possible contamination of bottles and (or) sample-splitting equipment. The plots in figures F12-F13 show that there were very few outliers for replicate analyses of 12 elements analyzed by the USGS Boulder lab during the study period. The relative standard deviation (RSD) of replicate analyses is another measure of analytical precision. A plot of the relation between RSD and concentration for six elements (fig. F14) shows, as expected, that RSD values generally were smaller at higher concentrations. For antimony, cadmium, copper, gadolinium, and lead, nearly all RSD values were less than 10 percent when concentrations were greater than 100 times the MDL, and most values were less than 20 percent when concentrations were between 10 and 100 times the MDL. For magnesium, RSD values were less than 20 percent for all concentrations, Average concentrations and standard deviations for replicate analyses of total mercury by the USGS Boulder lab are shown for filtered water (fig. F15) and unfiltered water (fig. F16). As with other constituents, standard deviations for analyses of total mercury represented a larger proportion of the amount present (corresponding to larger RSD values) at concentrations closer to the MDL. Therefore, the relative variability between replicate samples is highest at low concentrations.

\section{Split-Sample Comparison for Total Mercury}

During the study, a transition was made from the USGS Boulder lab to the USGS Wisconsin lab for the analysis of $\mathrm{Hg}_{\mathrm{T}}$ to take advantage of the lower detection limit of the methods used at the Wisconsin lab. Split-samples containing $\mathrm{Hg}_{\mathrm{T}}$ in filtered and unfiltered water were compared using 14 samples taken during the sampling events in November 2002 and January 2003. Two replicate bottles of each sample were sent to the Boulder lab and one replicate bottle was sent to the Wisconsin lab. Comparison of the results of the replicate analyses by the two laboratories (figs. F17 and F18) indicates excellent agreement for all samples with $\mathrm{Hg}_{\mathrm{T}}$ concentrations greater than $0.4 \mathrm{ng} / \mathrm{L}$, the MDL for $\mathrm{Hg}_{\mathrm{T}}$ at the Boulder lab.

\section{Filter Comparisons}

Two different filter types were used for $\mathrm{Hg}_{\mathrm{T}}$ and $\mathrm{MeHg}$ analyses: a Gelman capsule filter (C45, nominal pore diameter 0.45 micrometer) and a quartz fiber filter (QFF, nominal pore diameter 0.7 micrometer). The QFF was used so that particulate $\mathrm{Hg}_{\mathrm{T}}$ and $\mathrm{MeHg}$ could be measured directly, instead of by calculating the difference between unfiltered and filtered concentrations. Theoretically, one should get more precise data with lower variability, and a lower detection limit for particulate $\mathrm{Hg}_{\mathrm{T}}$ or $\mathrm{MeHg}$ using the QFF approach. An advantage to using both filter types is to increase comparability with other studies. The Gelman capsule filter has been used extensively by the USGS in northern California and nationally, including studies for the National Water-Quality Assessment Program (NAWQA; for example, Domagalski and others, 2000), a study of metals transport in the Sacramento River (Alpers and others, 2000), and several ongoing studies in the Sierra Nevada. The QFF approach has been used for mercury analysis by the USGS and other researchers in the Florida Everglades, in the USGS NAWQA National Mercury Project (Brigham and others, 2003), and in the Guadalupe River watershed of San Francisco Bay (Kuwabara and others, 2005).

Because of the different pore diameter, the QFF filtrate was expected to be higher in $\mathrm{Hg}_{\mathrm{T}}$ and $\mathrm{MeHg}$ than the C45 filtrate. Comparison of the filtrate data for total mercury (fig. F19A) indicates that this was indeed true for all but a small number of the samples. A linear least-squares regression for the 28 samples analyzed by the Wisconsin lab (fig. F19B) has a slope of 1.55 , indicating that about 55 percent more mercury passed through the QFF than through the C45 filters. Combining the QFF filtrate concentration with the particulate concentration trapped on the QFF for each sample should give an equivalent whole-water $\mathrm{Hg}_{\mathrm{T}}$ concentration that is similar to the $\mathrm{Hg}_{\mathrm{T}}$ concentration measured directly on an unfiltered sample. The results of this comparison (fig. F20) indicate a good to excellent correspondence for 42 of 45 samples from the two laboratories; three unexplained outliers had considerably more $\mathrm{Hg}_{\mathrm{T}}$ in the unfiltered split sample compared to the sum of QFF filtrate and particulate fractions. A similar comparison for MeHg (fig. F21) indicates excellent agreement for all samples with detectable MeHg. With regard to the comparison of MeHg concentrations in C45 and QFF filtrates (fig. F21), a large proportion of samples were non-detects by both procedures; in total, 54 samples were processed by both methods, of which 26 were non-detects for both filtered splits. An additional 7 samples had no $\mathrm{MeHg}$ detected in one split (MDL $0.04 \mathrm{ng} / \mathrm{L}$ ), whereas the other split had 0.04 or $0.05 \mathrm{ng} / \mathrm{L}$ detected. MeHg was detected in both splits in 18 of the samples; only 3 of the 54 samples are considered to be unexplained outliers. A comparison of results on split samples processed by different filter types (QFF and capsule filter) and analyzed for MeHg is shown in figure F22. The overall consistency of results provides confidence that the sum of QFF filtrate and particulate concentration could be used in cases where results from analysis of unfiltered samples were not available for either $\mathrm{Hg}_{\mathrm{T}}$ or $\mathrm{MeHg}$. 


\section{Results}

This section contains subsections describing results of field and laboratory measurements, followed by a subsection describing relations between concentrations of mercury and methylmercury and other water-quality constituents. A subsection on mercury bioaccumulation factors also is included.

\section{Field Measurements}

Camp Far West Reservoir goes through a seasonal cycle characterized by extreme drawdown in the late summer and early fall accompanied by thermal stratification with depth. Destratification occurs in the late fall, and the reservoir remains unstratified (vertically mixed) through winter and spring. This monomictic behavior is illustrated by field data for seasonal water-column profiles from three stations in the thalweg profile: site 2 (LRT, fig. 6A), site 4 (MRT, fig. 6B) and site 5 (BRA, fig. 6C). Representative seasonal profiles of field measurements from these stations indicate a strong seasonality, especially with regard to the vertical distribution of temperature and dissolved oxygen. The plots in figure 6 are constructed with a consistent vertical axis so that the seasonal variations in reservoir-surface elevation can been seen (for temporal variations in reservoir storage and surface elevation, see also fig. 4 and appendix A). Results of field measurements for the water-column profiles at all sites are given in appendix C (table C1) and plots of individual profiles are compiled in appendix D (figs. D1-D110). A summary of locations and dates when water-column profile data were collected within the reservoir is given in table C2.

In lakes or reservoirs with thermal stratification, three zones are defined (Wetzel, 1975): the hypolimnion is the relatively cold, deep water, the metalimnion is the transition zone, and the epilimnion is the relatively warm, surface layer. At times when the water column is not thermally stratified, the entire water column is considered to be the epilimnion. Field measurements at the time of sampling (table 1) were used to characterize each water-quality sample as representing either hypolimion, metalimnion, or epilimnion, and this property is indicated in figures throughout the report using distinct symbols. Thermal stratification in the summer and early fall is often accompanied by low values of dissolved oxygen (DO) at depth. In some cases, DO concentrations are less than $1 \mathrm{mg} / \mathrm{L}$, indicating anoxic conditions at depth. During the summer, when stratification of the water column is most widespread throughout the reservoir, the transition with depth from high DO to low DO commonly occurs in the metalimnion. At the LRT (fig. 6A) and MRT (fig. 6B) stations, the summer DO profiles show a minimum value in the metalimnion and somewhat higher DO values with depth. The summer depth profiles of $\mathrm{pH}$ and specific conductance (SC) at these stations show variations in the metalimnion that indicate a more complex stratification during that season. One possible interpretation is that sulfate reduction coupled with oxidation of organic carbon is taking place at the top of the hypolimnion, as discussed in section, "Relations of Mercury and Methylmercury with Other Constituents: Sulfur Isotopes."

The seasonal trends in temperature, $\mathrm{DO}, \mathrm{pH}$, and $\mathrm{SC}$ also can be seen in time-series plots showing measurements taken during water-quality sampling events (figs. $7 A-D)$. During the winter, the lake is well mixed and relatively cold; in February 2002, temperatures ranged from 7 to $9^{\circ} \mathrm{C}$, whereas in January 2003, the range was 8 to $12^{\circ} \mathrm{C}$. During summer stratification in 2002 and 2003, the minimum hypolimnion bottom-water temperatures usually were around $10-11^{\circ} \mathrm{C}$. Epilimnion temperatures reached highs of 26 to $28^{\circ} \mathrm{C}$ during August 2002 and 2003. Dissolved oxygen concentrations generally were low (less than or equal to $2 \mathrm{mg} / \mathrm{L}$ ), indicating suboxic to anoxic conditions in the hypolimnion; however, there were occasions such as fall 2002 and summer 2003 at the LRT station (site 2) when moderate DO values of 4 to $6 \mathrm{mg} / \mathrm{L}$ were observed in the hypolimnion (fig. 6A). Also, during winter 2002, DO values of 1 to $4 \mathrm{mg} / \mathrm{L}$ were observed in the Dairy Farm Mine pit lake (site 8) when this part of the reservoir was not thermally stratified (fig. 7B).

Acid mine drainage in the Dairy Farm Mine pit lake (station DFP; site 8) and associated impoundments (station DFI, site 9) typically had $\mathrm{pH}$ values in the range of 3 to 5 during the summer and fall (fig. 7C) when these areas were isolated from CFWR, and near-neutral values during winter and spring when the water bodies were connected because of higher water levels in CFWR. During the fall sampling events, the pit-lake water surface was at its lowest elevation, resulting in lowest $\mathrm{pH}$ values and highest values of specific conductance (SC), indicative of higher concentrations of many constituents. In CFWR, SC values generally were highest in the fall (fig. 7D), also associated with lowest water levels. Evaporative concentration is a likely contributing factor to the higher values of SC in the fall in both the pit lake and reservoir environments, as discussed in later sections on major elements and stable isotopes. Values of $\mathrm{pH}$ in the hypolimnion of CFWR generally were lower than epilimnion values by about 0.5 to 1.0 unit, which likely reflects higher total dissolved carbon dioxide associated with the respiring microbes and decomposing organic matter (Wetzel, 1975), processes that may be linked to sulfate reduction. 
$\boldsymbol{A}$

Temp.

Fall 2001

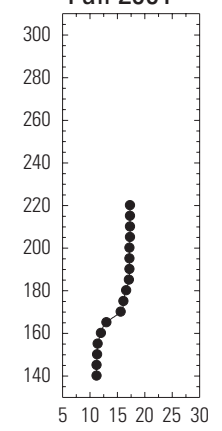

Winter 2002

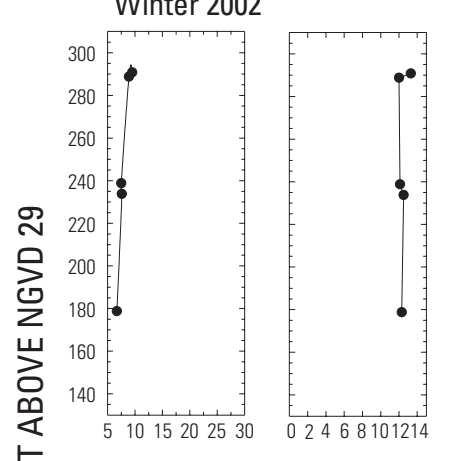

岀 Spring 2002
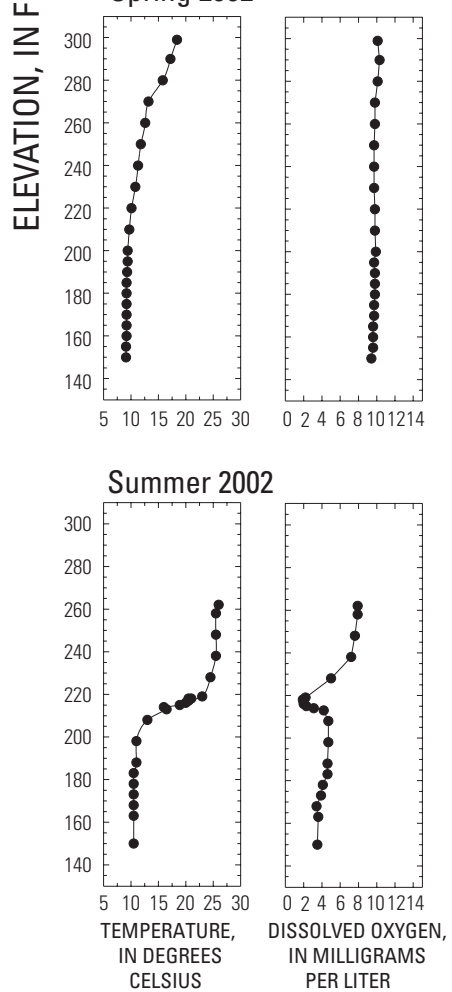

Site 2 - Lower Reservoir, Thalweg

$\begin{array}{llllll}\mathrm{pH} & \mathrm{SC} & \text { Temp. } & \mathrm{DO} & \mathrm{pH} & \mathrm{SC}\end{array}$
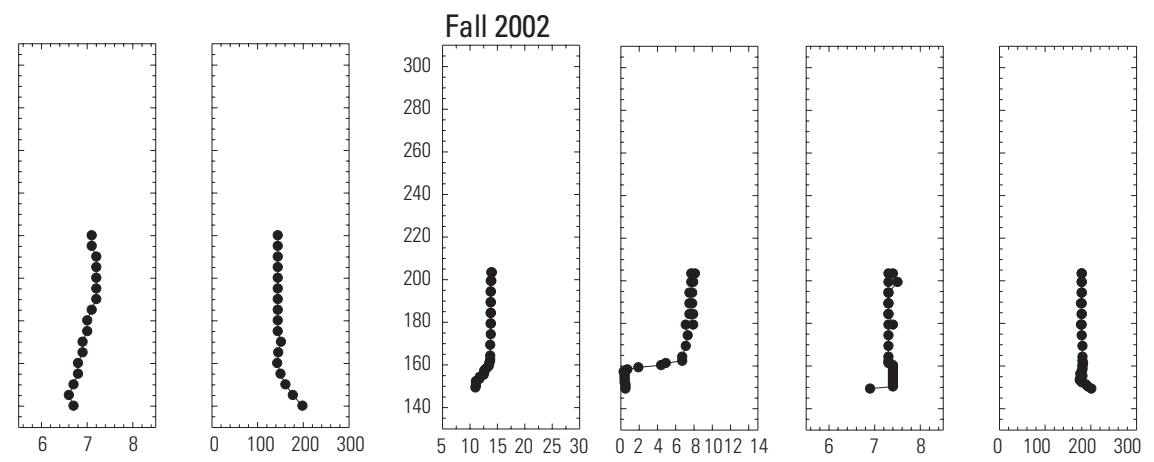

Winter 2003
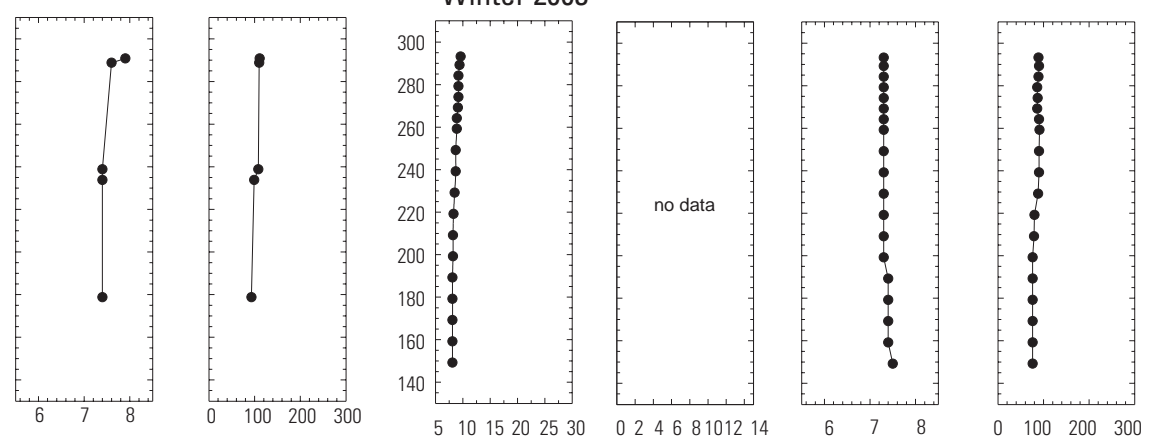

Spring 2003
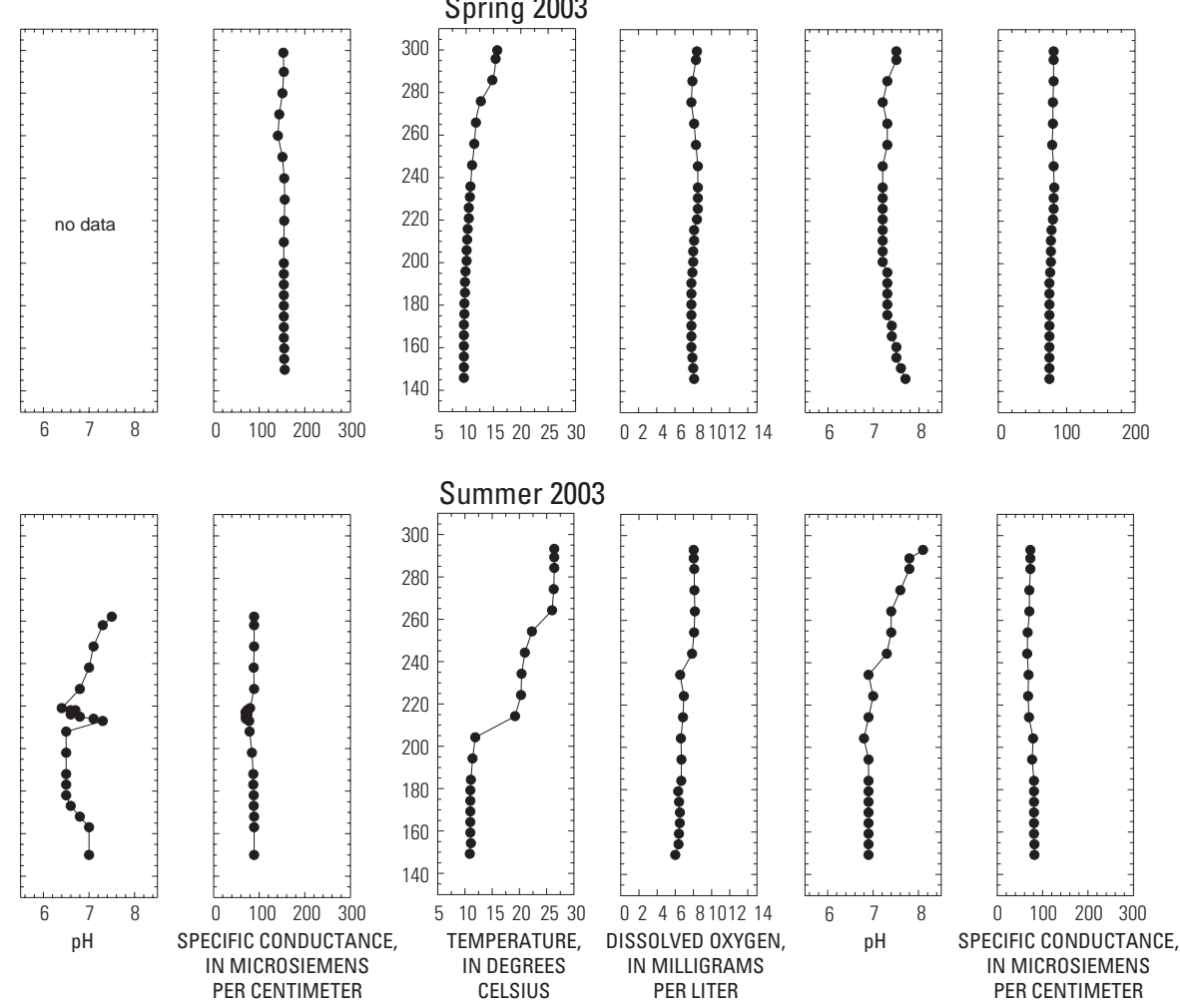

Figure 6. Water-column depth profiles of field measurements (temperature, dissolved oxygen, $\mathrm{pH}$, and specific conductance) quarterly from fall 2001 to summer 2003 at Camp Far West Reservoir, California:

(A) Site 2, Lower Reservoir, Thalweg, (B) Site 4, Mid-Reservoir, Thalweg, (C) Site 5, Bear River Arm. 
B

Temp. DO

Fall 2001

no data

Site 4 - Mid-Reservoir, Thalweg

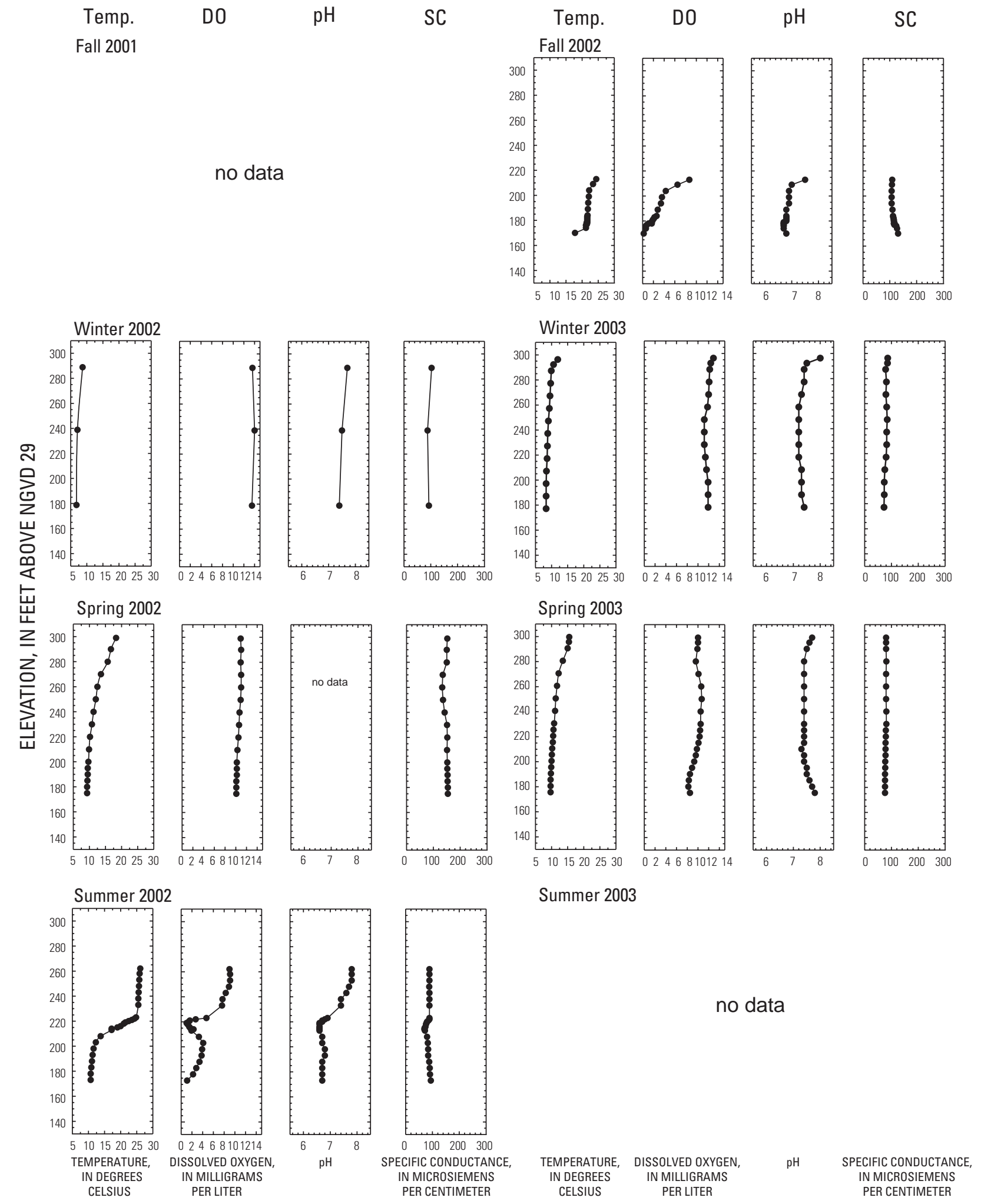

Figure 6. Continued. 
C

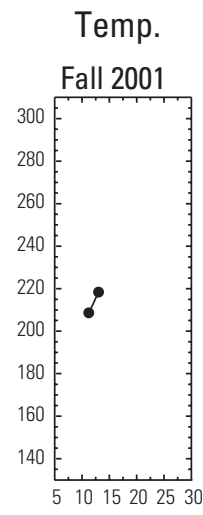

Winter 2002

Site 5 - Bear River Arm

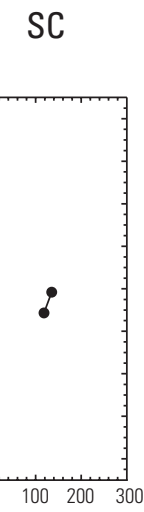

Temp.
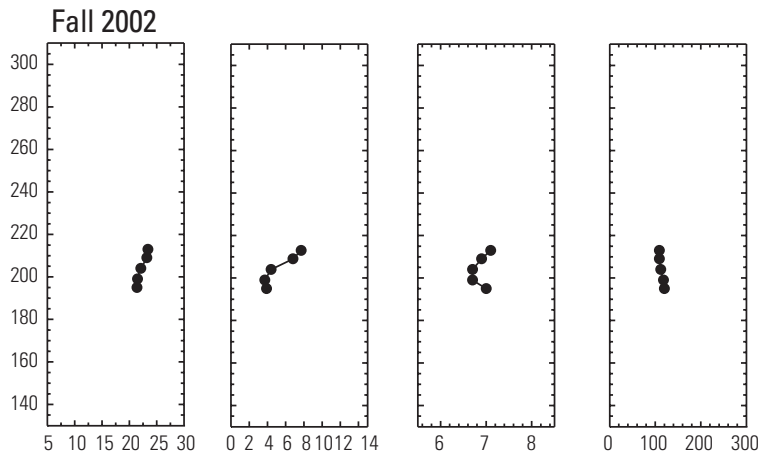

Winter 2003
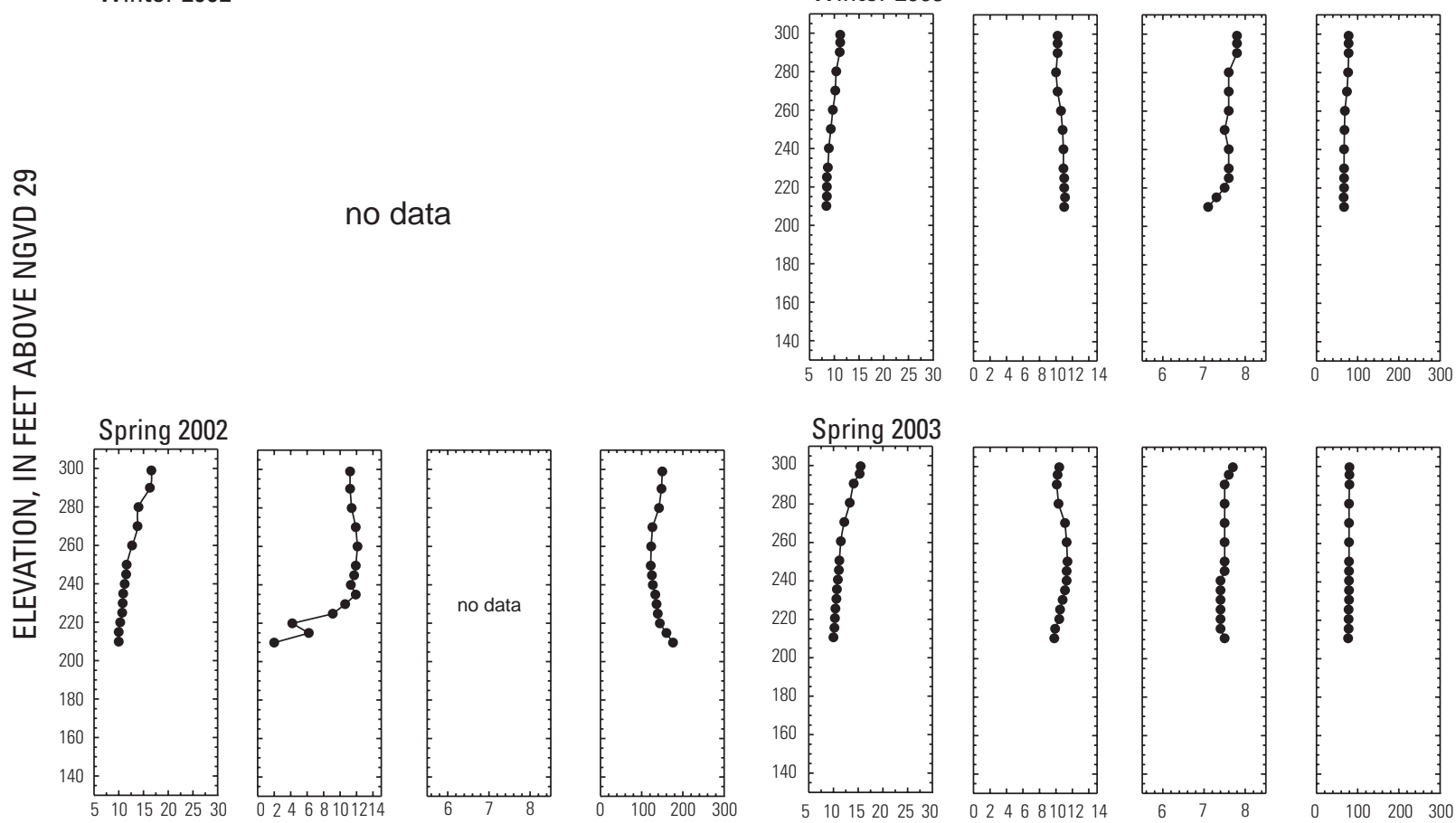

no data
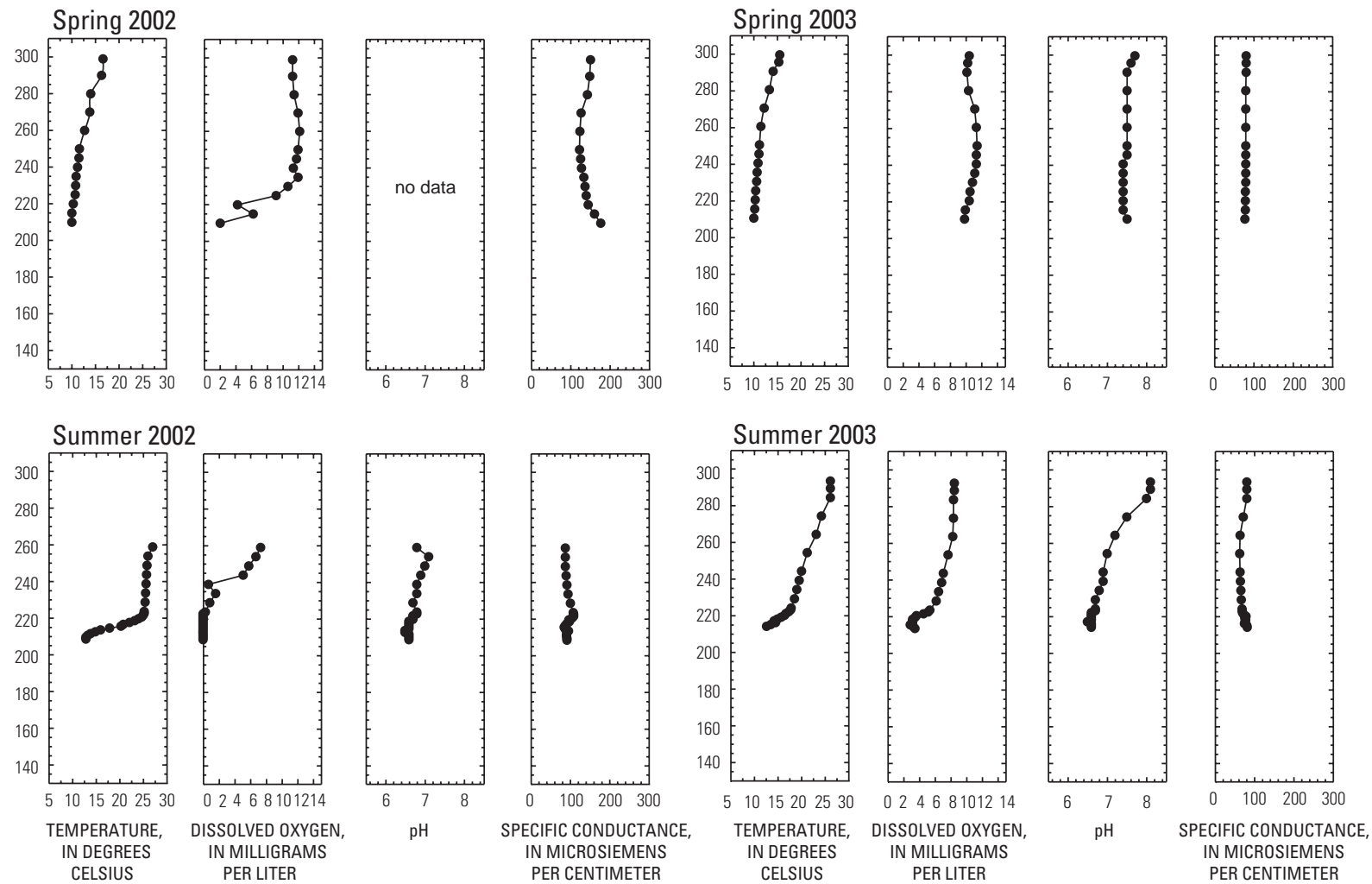

Figure 6. Continued. 

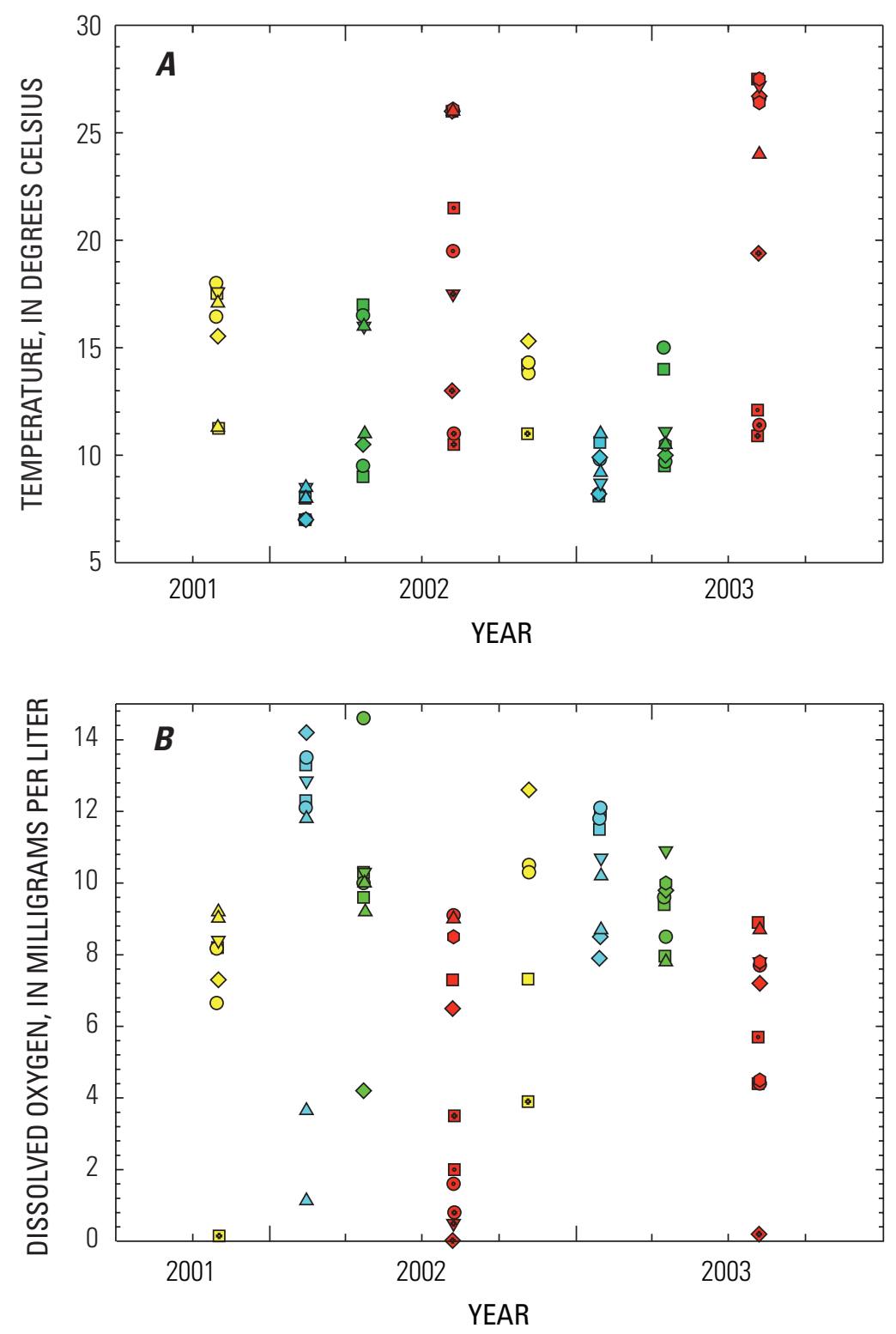

\section{EXPLANATION}

\begin{tabular}{|c|c|c|c|c|c|}
\hline & Site Number & Fall & Winter & Spring & Summer \\
\hline Lower reservoir & 1,2 & $\square$ & $\square$ & $\square$ & $\square$ \\
\hline Mid-reservoir & 3,4 & o & o & o & 0 \\
\hline Bear River arm & 5 & $\diamond$ & $\diamond$ & $\diamond$ & $\diamond$ \\
\hline Dairy Farm arm & 6 & $\nabla$ & $\nabla$ & $\nabla$ & $\nabla$ \\
\hline Rock Creek arm & 7 & 0 & 0 & 0 & 0 \\
\hline \multirow{2}{*}{$\begin{array}{l}\text { Dairy Farm Mine } \\
\text { pit lake and } \\
\text { impoundments }\end{array}$} & 8,9 & $\Delta$ & $\Delta$ & $\Delta$ & $\Delta$ \\
\hline & $\begin{array}{l}\square \circ \diamond \nabla \\
\square \odot \\
\odot \odot \diamond \nabla\end{array}$ & $\begin{array}{l}\text { Solid } \\
\text { Dot in } \\
\text { Cross }\end{array}$ & $\begin{array}{l}\text { ool ind } \\
\text { tes me }\end{array}$ & $\begin{array}{l}\text { sepilimr } \\
\text { nion } \\
\text { mnion }\end{array}$ & \\
\hline
\end{tabular}

Figure 7. Field measurements for sampling stations in Camp Far West Reservoir, California, 2001-03: $(A)$ Temperature, $(B)$ Dissolved oxygen, $(C) \mathrm{pH},(D)$ Specific conductance. 

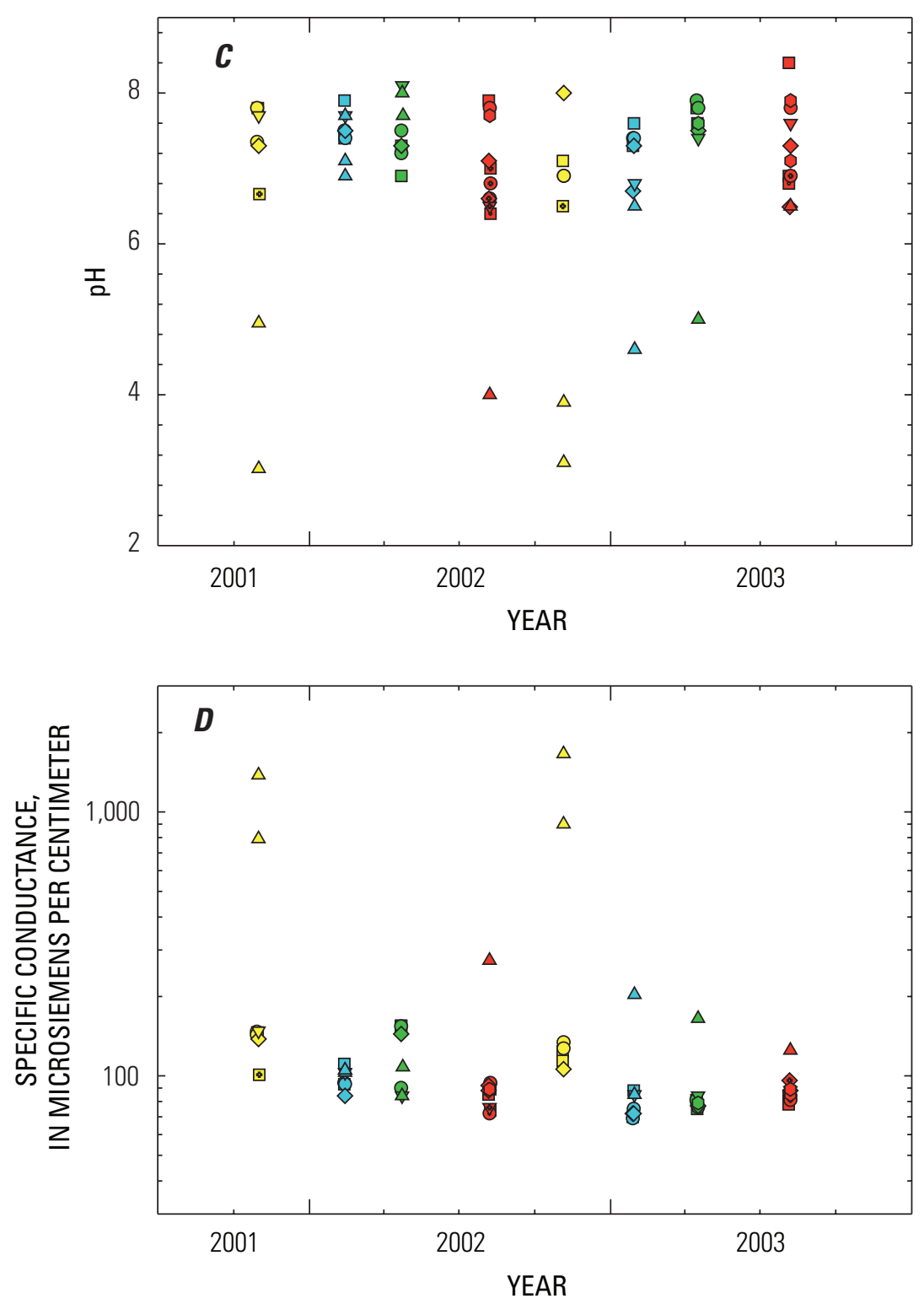

EXPLANATION

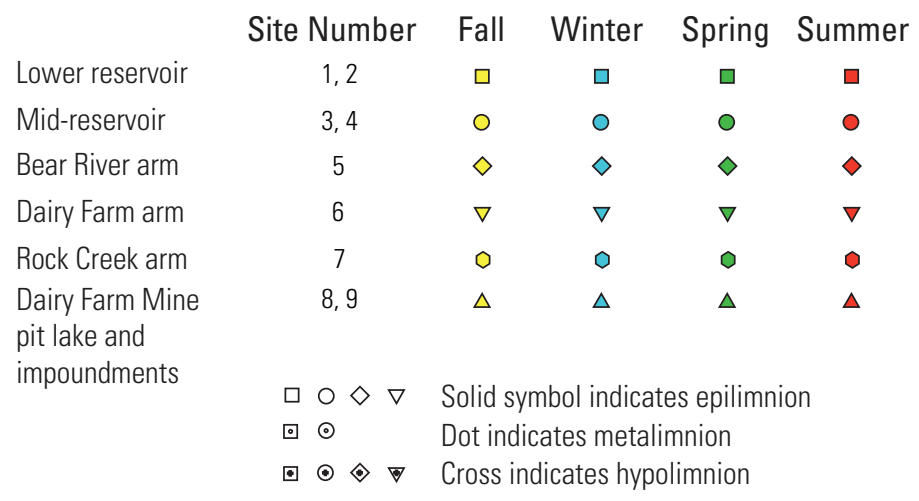

Figure 7. Continued. 


\section{Laboratory Measurements}

Results of laboratory measurements for constituents in water samples collected from Camp Far West Reservoir (CFWR) during October 2001 through August 2003 are shown in tables 2-7 and in appendix G (tables G1-G5). Seasonal and spatial variations of total mercury and methylmercury concentrations and their interpretation are the primary focus of this report. Raw concentration data for total mercury in water are given in appendix G (table G1 for unfiltered samples and table G2 for filtered and particulate samples); because two laboratories were used for total mercury determinations and many replicate determinations were made, best values of total mercury concentration were selected for each sample, as shown in table 6. Methylmercury concentration data are given in table 7. Data for other water-quality constituents are presented and discussed in the context of hydrobiogeochemical processes and effects on mercury and methylmercury cycling; these constituents include suspended solids (table 2), trace metals and major cations (appendix G, tables G3 and G4), major anions (table 3), nutrients and organic carbon (table 5), and chlorophyll (appendix G, table G5). Stable isotopes of oxygen and hydrogen in water (table 4) are presented and discussed in the context of understanding evapoconcentration effects and the elevation of precipitation and recharge; stable isotopes of sulfur and oxygen in aqueous sulfate (table 4) are relevant to understanding possible sources of sulfate and processes of sulfate reduction.

Table 2. Data for suspended solids in water samples, Camp Far West Reservoir, California.

[Thalweg, former river channel (low elevation path). The number in parentheses is the data parameter code, a five-digit code used in the U.S. Geological Survey computerized data system. Suspended silt plus clay is the product of suspended sediment concentration and percent suspended sediment sieved. Organic material is included in suspended sediment concentration, which is used interchangeably with suspended solids concentration in this report; $\mathrm{ft}$, foot; mm, millimeter; $\mathrm{mg} / \mathrm{L}$, milligram per liter; $\%<$, percent less than; -, not determined]

\begin{tabular}{|c|c|c|c|c|c|}
\hline Date & Time & $\begin{array}{c}\text { Depth } \\
\text { (ft) }\end{array}$ & $\begin{array}{c}\text { Suspended } \\
\text { sediment } \\
(\mathrm{mg} / \mathrm{L}) \\
(80154)\end{array}$ & $\begin{array}{c}\text { Suspended } \\
\text { sediment } \\
\text { sieved } \\
(\%<0.063 \mathrm{~mm}) \\
(70331)\end{array}$ & $\begin{array}{r}\text { Suspenc } \\
\text { silt } \\
\text { plus cl } \\
\text { (mg/L }\end{array}$ \\
\hline \multicolumn{6}{|c|}{ Site 1, LRS: Lower Reservoir, Shallow (Camp Far West Reservoir 0.3 mile north of dam abutment) } \\
\hline \multicolumn{6}{|c|}{ Station number 390317121185001} \\
\hline $10 / 30 / 2001$ & $5: 15 \mathrm{PM}$ & 10 & 8 & 92 & 7 \\
\hline $02 / 12 / 2002$ & 12:00 PM & 8 & 10 & 93 & 9 \\
\hline $04 / 22 / 2002$ & 3:20 PM & 10 & 5 & 87 & 4 \\
\hline 08/06/2002 & 4:30 PM & 10 & $<1$ & 67 & $<1$ \\
\hline $04 / 15 / 2003$ & 10:30 AM & 40 & 14 & 10 & 1 \\
\hline \multicolumn{6}{|c|}{ Site 2, LRT: Lower Reservoir, Thalweg (Camp Far West Reservoir in thalweg near dam near Wheatland) } \\
\hline \multicolumn{6}{|c|}{ Station number 390307121183801} \\
\hline $11 / 01 / 2001$ & 8:30 AM & 70 & 22 & 91 & 20 \\
\hline $02 / 12 / 2002$ & 11:00 AM & 140 & 5 & 85 & 4 \\
\hline $04 / 22 / 2002$ & 3:00 PM & 140 & 5 & 74 & 4 \\
\hline 08/08/2002 & 12:00 PM & 45 & 6 & 92 & 6 \\
\hline 08/08/2002 & 1:30 PM & 113 & 7 & 86 & 6 \\
\hline $11 / 04 / 2002$ & 3:50 PM & 10 & 16 & 99 & 16 \\
\hline $11 / 04 / 2002$ & 3:20 PM & 55 & 11 & 99 & 11 \\
\hline $01 / 29 / 2003$ & 2:30 PM & 10 & 1 & 80 & 1 \\
\hline $01 / 28 / 2003$ & 4:40 PM & 140 & 6 & 90 & 5 \\
\hline $04 / 16 / 2003$ & 4:00 PM & 150 & 10 & 93 & 9 \\
\hline 08/05/2003 & $12: 30 \mathrm{PM}$ & 1 & 28 & 63 & 18 \\
\hline $08 / 05 / 2003$ & 3:30 PM & 73 & 12 & 92 & 11 \\
\hline $08 / 05 / 2003$ & 1:00 PM & 120 & 11 & 90 & 10 \\
\hline
\end{tabular}


Table 2. Data for suspended solids in water samples, Camp Far West Reservoir, California._Continued

[Thalweg, former river channel (low elevation path). The number in parentheses is the data parameter code, a five-digit code used in the U.S. Geological Survey computerized data system. Suspended silt plus clay is the product of suspended sediment concentration and percent suspended sediment sieved. Organic material is included in suspended sediment concentration, which is used interchangeably with suspended solids concentration in this report; ft, foot; mm, millimeter; mg/L, milligram per liter; $\%<$, percent less than; -, not determined]

\begin{tabular}{|c|c|c|c|c|c|}
\hline Date & Time & $\begin{array}{c}\text { Depth } \\
\text { (ft) }\end{array}$ & $\begin{array}{c}\text { Suspended } \\
\text { sediment } \\
\text { (mg/L) } \\
(80154)\end{array}$ & 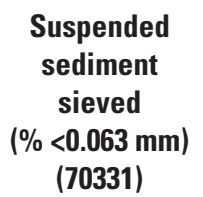 & $\begin{array}{l}\text { Suspended } \\
\text { silt } \\
\text { plus clay } \\
\text { (mg/L) }\end{array}$ \\
\hline
\end{tabular}

Site 3, MRS: Middle Reservoir, Shallow (Camp Far West Reservoir east shoreline 1.6 miles above dam) Station number 390244121171801

$\begin{array}{rrrrrr}10 / 29 / 2001 & 4: 15 \text { PM } & 6 & 4 & 93 & 4 \\ 02 / 12 / 2002 & 1: 30 \mathrm{PM} & 60 & 7 & 96 & 7 \\ 04 / 22 / 2002 & 1: 50 \mathrm{PM} & 10 & 9 & 93 & 8 \\ 04 / 15 / 2003 & 12: 40 \mathrm{PM} & 32 & 15 & 64 & 10\end{array}$

Site 4, MRT: Middle Reservoir, Thalweg (Camp Far West Reservoir in thalweg 1.5 miles above dam) Station number 390238121173101

\begin{tabular}{|c|c|c|c|c|c|}
\hline $10 / 29 / 2001$ & $2: 45$ PM & 50 & 30 & 100 & 30 \\
\hline $02 / 13 / 2002$ & 8:30 AM & 120 & 5 & 84 & 4 \\
\hline $04 / 22 / 2002$ & 12:20 PM & 120 & 5 & 92 & 5 \\
\hline 08/07/2002 & 12:10 PM & 10 & 3 & 52 & 2 \\
\hline 08/07/2002 & $12: 40 \mathrm{PM}$ & 47 & 9 & 80 & 7 \\
\hline 08/08/2002 & 2:50 PM & 80 & 9 & 92 & 8 \\
\hline $11 / 05 / 2002$ & $2: 30 \mathrm{PM}$ & 10 & 10 & 93 & 9 \\
\hline $11 / 05 / 2002$ & 2:10 PM & 30 & 21 & 99 & 21 \\
\hline $01 / 29 / 2003$ & 2:00 PM & 10 & 1 & 92 & 1 \\
\hline $01 / 28 / 2003$ & 3:30 PM & 120 & 3 & 96 & 3 \\
\hline $04 / 17 / 2003$ & 10:30 AM & 125 & 4 & 87 & 3 \\
\hline 08/07/2003 & 11:30 AM & 1 & 27 & 94 & 25 \\
\hline 08/07/2003 & 11:50 AM & 100 & 11 & 94 & 10 \\
\hline
\end{tabular}

Site 5, BRA: Bear River arm (Camp Far West Reservoir Bear River arm near Wheatland) Station number 390202121162201

$\begin{array}{rrrrrr}10 / 31 / 2001 & 10: 15 \mathrm{AM} & 12 & 17 & 97 & 16 \\ 02 / 13 / 2002 & 9: 00 \mathrm{AM} & 80 & 11 & 91 & 10 \\ 04 / 22 / 2002 & 10: 40 \mathrm{AM} & 80 & 8 & 88 & 7 \\ 08 / 06 / 2002 & 5: 50 \mathrm{PM} & 10 & 3 & 56 & 2 \\ 08 / 06 / 2002 & 6: 20 \mathrm{PM} & 55 & 6 & 72 & 4 \\ 11 / 05 / 2002 & 4: 10 \mathrm{PM} & 7 & 9 & 94 & 8 \\ 01 / 29 / 2003 & 1: 20 \mathrm{PM} & 10 & 1 & 90 & 1 \\ 01 / 28 / 2003 & 2: 50 \mathrm{PM} & 85 & 3 & 96 & 3 \\ 04 / 17 / 2003 & 11: 30 \mathrm{AM} & 90 & 10 & 88 & 9 \\ 08 / 07 / 2003 & 10: 00 \mathrm{AM} & 1 & 27 & 62 & 17 \\ 08 / 06 / 2003 & 3: 00 \mathrm{PM} & 100 & 19 & 87 & 17\end{array}$


Table 2. Data for suspended solids in water samples, Camp Far West Reservoir, California._Continued

[Thalweg, former river channel (low elevation path). The number in parentheses is the data parameter code, a five-digit code used in the U.S. Geological Survey computerized data system. Suspended silt plus clay is the product of suspended sediment concentration and percent suspended sediment sieved. Organic material is included in suspended sediment concentration, which is used interchangeably with suspended solids concentration in this report; ft, foot; mm, millimeter; mg/L, milligram per liter; $\%<$, percent less than; -, not determined]

\begin{tabular}{|c|c|c|c|c|c|}
\hline Date & Time & $\begin{array}{c}\text { Depth } \\
\text { (ft) }\end{array}$ & $\begin{array}{c}\text { Suspended } \\
\text { sediment } \\
\text { (mg/L) } \\
(80154)\end{array}$ & $\begin{array}{c}\text { Suspended } \\
\text { sediment } \\
\text { sieved } \\
(\%<0.063 \mathrm{~mm}) \\
(70331)\end{array}$ & $\begin{array}{c}\text { Suspended } \\
\text { silt } \\
\text { plus clay } \\
\text { (mg/L) }\end{array}$ \\
\hline
\end{tabular}

Site 6, DFA: Dairy Farm arm (Camp Far West Reservoir Dairy Farm arm near Wheatland)

Station number 390159121171401

\begin{tabular}{|c|c|c|c|c|}
\hline $10 / 31 / 2001$ & 1:00 PM & 4 & 6 & 97 \\
\hline $02 / 13 / 2002$ & 1:00 PM & 20 & 5 & 97 \\
\hline $04 / 23 / 2002$ & 12:10 PM & 20 & 3 & 91 \\
\hline 08/07/2002 & 6:50 PM & 57 & 5 & 97 \\
\hline $01 / 30 / 2003$ & 3:30 PM & 55 & 2 & 93 \\
\hline $04 / 17 / 2003$ & 2:30 PM & 55 & 11 & 97 \\
\hline 08/07/2003 & 4:00 PM & 1 & 27 & 83 \\
\hline
\end{tabular}

Site 7, RCA: Rock Creek arm (Camp Far West Reservoir Rock Creek arm)

Station number 390331121174101

$\begin{array}{rrrrrr}08 / 07 / 2002 & 03: 40 \mathrm{PM} & 10 & 3 & 81 & 2 \\ 04 / 17 / 2003 & 01: 20 \mathrm{PM} & 80 & 11 & 95 & 10 \\ 08 / 07 / 2003 & 01: 00 \mathrm{PM} & 1 & 28 & 97 & 27 \\ 08 / 07 / 2003 & 01: 30 \mathrm{PM} & 40 & 26 & 88 & 23\end{array}$

Site 8, DFP: Dairy Farm Mine Pit Lake (Dairy Farm Mine pit lake near Wheatland)

Station number 390148121171701

$\begin{array}{rrrrrr}10 / 31 / 2001 & 2: 15 \text { PM } & 1 & - & - & - \\ 02 / 13 / 2002 & 3: 10 \text { PM } & 10 & 8 & 88 & 7 \\ 02 / 13 / 2002 & 3: 30 \text { PM } & 35 & 5 & 93 & 5 \\ 04 / 24 / 2002 & 11: 10 \mathrm{AM} & 30 & 6 & 91 & 5 \\ 08 / 07 / 2002 & 5: 00 \mathrm{PM} & 0.5 & 3 & 73 & 2 \\ 11 / 05 / 2002 & 2: 50 \mathrm{PM} & 1 & 6 & 54 & 3 \\ 01 / 30 / 2003 & 12: 30 \mathrm{PM} & 10 & 1 & 86 & 1 \\ 01 / 30 / 2003 & 1: 20 \mathrm{PM} & 38 & <1 & 50 & <1 \\ 04 / 17 / 2003 & 4: 00 \mathrm{PM} & 40 & 11 & 43 & 5 \\ 08 / 07 / 2003 & 4: 30 \mathrm{PM} & 1 & 24 & 89 & 21\end{array}$

Site 9, DFI: Dairy Farm Mine Impoundments (Camp Far West Reservoir impoundment Dairy Farm Mine arm) Station number 390152121171001

\begin{tabular}{llcccc}
$10 / 31 / 2001$ & $02: 40 \mathrm{PM}$ & 0.5 & - & - & - \\
$02 / 13 / 2002$ & $2: 20 \mathrm{PM}$ & 52 & 6 & 89 & 5 \\
$04 / 23 / 2002$ & $1: 10 \mathrm{PM}$ & 20 & 5 & 92 & 5 \\
$11 / 05 / 2002$ & $2: 00 \mathrm{PM}$ & 0.5 & 5 & 90 & 5 \\
\hline
\end{tabular}


Table 3. Data for major anions (chloride, sulfate, and alkalinity, a proxy for bicarbonate) in filtered water samples, Camp Far West Reservoir, California.

[The number in parentheses is the data parameter code, a five-digit code used in the U.S. Geological Survey computerized data system. Thalweg, former river channel (low elevation path). $\mathrm{CaCO}_{3}$, calcium carbonate; ft, foot; mg/L, milligram per liter; -, not determined]

\begin{tabular}{|c|c|c|c|c|c|}
\hline Date & Time & $\begin{array}{c}\text { Depth } \\
\text { (ft) }\end{array}$ & $\begin{array}{c}\text { Chloride } \\
\text { (CI) } \\
(\mathrm{mg} / \mathrm{L}) \\
(00940)\end{array}$ & $\begin{array}{c}\text { Sulfate } \\
\left(\mathrm{SO}_{4}\right) \\
(\mathrm{mg} / \mathrm{L}) \\
(99113)\end{array}$ & $\begin{array}{c}\text { Alkalinity } \\
\text { (mg/L as } \\
\text { CaCO }) \\
(29803)\end{array}$ \\
\hline
\end{tabular}

Site 1, LRS: Lower Reservoir, Shallow (Camp Far West Reservoir 0.3 mile north of dam abutment)

$\begin{array}{crrrrr}\text { Station number } 390317121185001 & & & & \\ 10 / 30 / 2001 & 5: 15 \mathrm{PM} & 10 & 7.1 & 8.8 & 52 \\ 02 / 12 / 2002 & 12: 00 \mathrm{PM} & 8 & 4.9 & 7.0 & 33 \\ 04 / 22 / 2002 & 3: 20 \mathrm{PM} & 10 & 4.5 & 5.4 & 27 \\ 08 / 06 / 2002 & 4: 30 \mathrm{PM} & 10 & 5.2 & 4.8 & 27 \\ 04 / 15 / 2003 & 10: 30 \mathrm{AM} & 40 & 4.1 & 4.4 & 26\end{array}$

Site 2, LRT: Lower Reservoir, Thalweg (Camp Far West Reservoir in thalweg near dam near Wheatland)

Station number 390307121183801

$\begin{array}{lrrlll}11 / 01 / 2001 & 8: 30 \mathrm{AM} & 70 & 5.4 & 6.3 & 60 \\ 02 / 12 / 2002 & 11: 00 \mathrm{AM} & 140 & 4.7 & 6.0 & 27 \\ 04 / 22 / 2002 & 3: 00 \mathrm{PM} & 140 & 4.3 & 5.5 & 27 \\ 08 / 08 / 2002 & 12: 00 \mathrm{PM} & 45 & 4.6 & 4.2 & 24 \\ 08 / 08 / 2002 & 1: 30 \mathrm{PM} & 113 & 5.0 & 5.1 & 31 \\ 11 / 04 / 2002 & 3: 50 \mathrm{PM} & 10 & 5.7 & 6.2 & 41 \\ 11 / 04 / 2002 & 3: 20 \mathrm{PM} & 55 & 6.1 & 6.7 & 40 \\ 01 / 29 / 2003 & 2: 30 \mathrm{PM} & 10 & 4.4 & 5.9 & 21 \\ 01 / 28 / 2003 & 4: 40 \mathrm{PM} & 140 & 3.6 & 4.4 & 20 \\ 04 / 16 / 2003 & 4: 00 \mathrm{PM} & 150 & 4.0 & 4.1 & 22 \\ 08 / 05 / 2003 & 12: 30 \mathrm{PM} & 1 & 4.6 & 3.9 & 28 \\ 08 / 05 / 2003 & 3: 30 \mathrm{PM} & 73 & 4.1 & 4.2 & 23 \\ 08 / 05 / 2003 & 1: 00 \mathrm{PM} & 120 & 4.1 & 4.0 & 32\end{array}$

Site 3, MRS: Middle Reservoir, Shallow (Camp Far West Reservoir east shoreline 1.6 miles above dam)

Station number 390244121171801

$\begin{array}{lrrrrr}10 / 29 / 2001 & 4: 15 \text { PM } & 6 & 7.2 & 7.5 & 51 \\ 02 / 12 / 2002 & 1: 30 \text { PM } & 60 & 4.9 & 7.0 & 33 \\ 04 / 22 / 2002 & 1: 50 \text { PM } & 10 & 4.7 & 5.0 & 27 \\ 04 / 15 / 2003 & 12: 40 \text { PM } & 32 & 4.1 & 4.5 & 25\end{array}$

Site 4, MRT: Middle Reservoir, Thalweg (Camp Far West Reservoir in thalweg 1.5 miles above dam)

Station number 390238121173101

$\begin{array}{lrrlll}10 / 29 / 2001 & 2: 45 \mathrm{PM} & 50 & 6.9 & 6.9 & 51 \\ 02 / 13 / 2002 & 8: 30 \mathrm{AM} & 120 & 4.5 & 6.7 & 29 \\ 04 / 22 / 2002 & 12: 20 \mathrm{PM} & 120 & 4.4 & 5.5 & 28 \\ 08 / 07 / 2002 & 12: 10 \mathrm{PM} & 10 & 5.4 & 5.0 & 30 \\ 08 / 07 / 2002 & 12: 40 \mathrm{PM} & 47 & 4.8 & 4.4 & 29 \\ 08 / 08 / 2002 & 2: 50 \mathrm{PM} & 80 & 5.0 & 4.9 & 30 \\ 11 / 05 / 2002 & 2: 30 \mathrm{PM} & 10 & 6.2 & 7.5 & 43 \\ 11 / 05 / 2002 & 2: 10 \mathrm{PM} & 30 & 6.6 & 8.7 & 45 \\ 01 / 29 / 2003 & 2: 00 \mathrm{PM} & 10 & 4.1 & 5.2 & - \\ 01 / 28 / 2003 & 3: 30 \mathrm{PM} & 120 & 3.7 & 4.5 & 21 \\ 04 / 17 / 2003 & 10: 30 \mathrm{AM} & 125 & 4.1 & 4.1 & 24 \\ 08 / 07 / 2003 & 11: 30 \mathrm{AM} & 1 & 4.9 & 4.1 & 23 \\ 08 / 07 / 2003 & 11: 50 \mathrm{AM} & 100 & 4.4 & 4.0 & 32\end{array}$


Table 3. Data for major anions (chloride, sulfate, and alkalinity, a proxy for bicarbonate) in filtered water samples, Camp Far West Reservoir, California.-Continued

[The number in parentheses is the data parameter code, a five-digit code used in the U.S. Geological Survey computerized data system. Thalweg, former river channel (low elevation path). $\mathrm{CaCO}_{3}$, calcium carbonate; ft, foot; mg/L, milligram per liter; - not determined]

\begin{tabular}{|c|c|c|c|c|c|}
\hline Date & Time & $\begin{array}{c}\text { Depth } \\
\text { (ft) }\end{array}$ & $\begin{array}{c}\text { Chloride } \\
\text { (CI) } \\
(\mathrm{mg} / \mathrm{L}) \\
(00940)\end{array}$ & $\begin{array}{c}\text { Sulfate } \\
\left(\mathrm{SO}_{4}\right) \\
\left(\mathrm{mg}^{\prime} \mathrm{L}\right) \\
(99113)\end{array}$ & $\begin{array}{c}\text { Alkalinity } \\
\text { (mg/L as } \\
\left.\mathrm{CaCO}_{3}\right) \\
(29803)\end{array}$ \\
\hline \multicolumn{6}{|c|}{$\begin{array}{l}\text { Site 5, BRA: Bear River arm (Camp Far West Reservoir Bear River arm near Wheatland) } \\
\text { Station number } 390202121162201\end{array}$} \\
\hline $10 / 31 / 2001$ & 10:15 AM & 12 & 7.5 & 9.2 & - \\
\hline $02 / 13 / 2002$ & 9:00 AM & 80 & 4.7 & 6.1 & 25 \\
\hline $04 / 22 / 2002$ & 10:40 AM & 80 & 4.5 & 5.1 & 26 \\
\hline $08 / 06 / 2002$ & 5:50 PM & 10 & 5.4 & 4.9 & 31 \\
\hline 08/06/2002 & 6:20 PM & 55 & 5.0 & 4.4 & 32 \\
\hline $11 / 05 / 2002$ & 4:10 PM & 7 & 6.2 & 7.7 & 43 \\
\hline $01 / 29 / 2003$ & 1:20 PM & 10 & 3.6 & 4.0 & 21 \\
\hline $01 / 28 / 2003$ & 2:50 PM & 85 & 3.7 & 4.4 & - \\
\hline $04 / 17 / 2003$ & 11:30 AM & 90 & 4.1 & 3.9 & 26 \\
\hline $08 / 07 / 2003$ & 10:00 AM & 1 & 5.1 & 4.1 & 24 \\
\hline $08 / 06 / 2003$ & 3:00 PM & 100 & 4.7 & 3.8 & 26 \\
\hline
\end{tabular}

Site 6, DFA: Dairy Farm arm (Camp Far West Reservoir Dairy Farm arm near Wheatland) Station number 390159121171401

$\begin{array}{lrrrrl}10 / 31 / 2001 & 1: 00 \mathrm{PM} & 4 & 7.5 & 9.8 & 50 \\ 02 / 13 / 2002 & 1: 00 \mathrm{PM} & 20 & 4.6 & 7.5 & 32 \\ 04 / 23 / 2002 & 12: 10 \mathrm{PM} & 20 & 4.6 & 5.6 & 30 \\ 08 / 07 / 2002 & 6: 50 \mathrm{PM} & 57 & 5.1 & 4.9 & 30 \\ 01 / 30 / 2003 & 3: 30 \mathrm{PM} & 55 & 3.9 & 5.3 & - \\ 04 / 17 / 2003 & 2: 30 \mathrm{PM} & 55 & 4.4 & 5.3 & 27 \\ 08 / 07 / 2003 & 4: 00 \mathrm{PM} & 1 & 4.7 & 6.1 & 26\end{array}$

Site 7, RCA: Rock Creek arm (Camp Far West Reservoir Rock Creek arm) Station number 390331121174101

$\begin{array}{llrlll}08 / 07 / 2002 & 03: 40 \mathrm{PM} & 10 & 5.3 & 4.9 & 31 \\ 04 / 17 / 2003 & 01: 20 \mathrm{PM} & 80 & 4.2 & 4.2 & 25 \\ 08 / 07 / 2003 & 01: 00 \mathrm{PM} & 1 & 5.0 & 4.0 & 28 \\ 08 / 07 / 2003 & 01: 30 \mathrm{PM} & 40 & 4.8 & 3.6 & 23\end{array}$

Site 8, DFP: Dairy Farm Mine Pit Lake (Dairy Farm Mine pit lake near Wheatland) Station number 390148121171701

$\begin{array}{lrcccc}10 / 31 / 2001 & 2: 15 \mathrm{PM} & 1 & 4.3 & 636 & - \\ 02 / 13 / 2002 & 3: 10 \mathrm{PM} & 10 & 5.1 & 8.5 & 29 \\ 02 / 13 / 2002 & 3: 30 \mathrm{PM} & 35 & - & - & 26 \\ 04 / 24 / 2002 & 11: 10 \mathrm{AM} & 30 & 4.5 & 7.8 & 23 \\ 08 / 07 / 2002 & 5: 00 \mathrm{PM} & 0.5 & 6.4 & 112 & - \\ 11 / 05 / 2002 & 2: 50 \mathrm{PM} & 1 & 5.2 & 381 & - \\ 01 / 30 / 2003 & 12: 30 \mathrm{PM} & 10 & 4.5 & 77 & 26 \\ 01 / 30 / 2003 & 1: 20 \mathrm{PM} & 38 & 4.1 & 6.3 & 23 \\ 04 / 17 / 2003 & 4: 00 \mathrm{PM} & 40 & 4.1 & 92 & - \\ 08 / 07 / 2003 & 4: 30 \mathrm{PM} & 1 & 4.8 & 37 & 5\end{array}$

Site 9, DFI: Dairy Farm Mine Impoundments (Camp Far West Reservoir impoundment Dairy Farm Mine arm)

Station number 390152121171001

$\begin{array}{llcccl}10 / 31 / 2001 & 2: 40 \text { PM } & 0.5 & 66 & 355 & - \\ 02 / 13 / 2002 & 2: 20 \text { PM } & 52 & 4.6 & 11 & 28 \\ 04 / 23 / 2002 & 1: 10 \text { PM } & 20 & 4.5 & 5.6 & 28 \\ 11 / 05 / 2002 & 2: 00 \text { PM } & 0.5 & 11 & 1,145 & -\end{array}$


Table 4. Data for oxygen and sulfur isotopes in aqueous sulfate and oxygen and hydrogen isotopes in water, Camp Far West Reservoir, California.

$\left[\delta^{34} \mathrm{~S} \mathrm{SO}_{4}\right.$, delta-sulfur-34 in aqueous sulfate; $\delta^{18} \mathrm{O} \mathrm{SO}_{4}$, delta-oxygen-18 in aqueous sulfate; $\delta^{18} \mathrm{O} \mathrm{H}_{2} \mathrm{O}$, delta-oxygen-18 in water; $\delta \mathrm{D} \mathrm{H}_{2} \mathrm{O}$, delta-deuterium in water. VSMOW, Vienna Standard Mean Ocean Water; CDT, Cañon Diablo Troilite; (1 of 2) and (2 of 2) refer to replicate analyses. ft, foot; permil, per thousand; - , not determined]

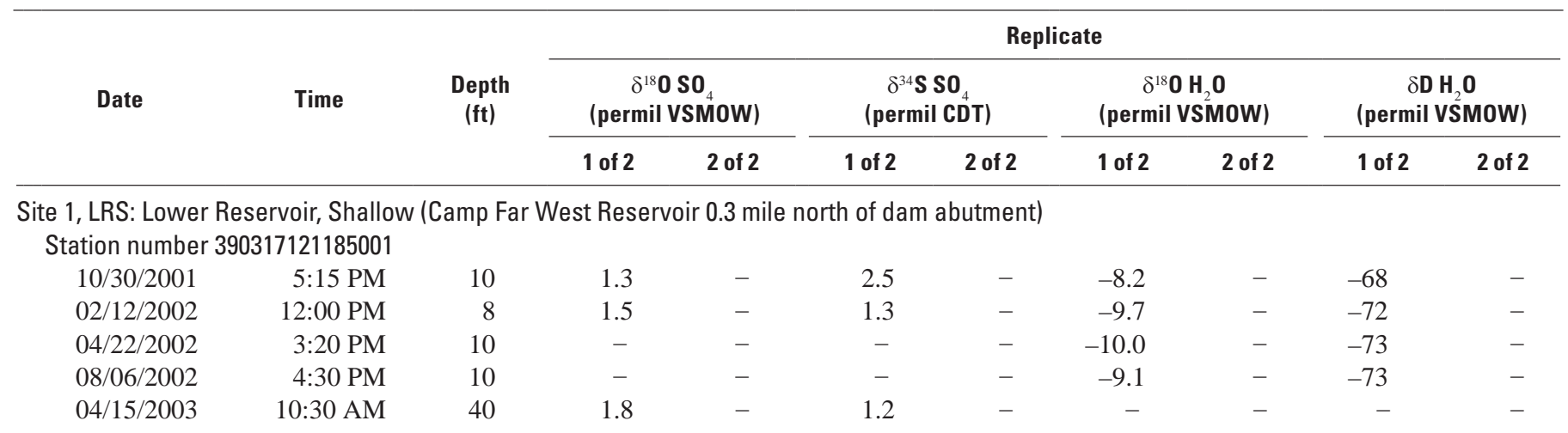

Site 2, LRT: Lower Reservoir, Thalweg (Camp Far West Reservoir in thalweg near dam near Wheatland)

Station number 390307121183801

\begin{tabular}{|c|c|c|c|c|c|c|c|c|c|c|}
\hline $11 / 01 / 2001$ & 8:30 AM & 70 & 2.2 & - & 3.2 & - & -10.2 & - & -76 & -76 \\
\hline $02 / 12 / 2002$ & 11:00 AM & 140 & 2.4 & - & 0.9 & - & -10.4 & - & -77 & - \\
\hline $04 / 22 / 2002$ & 3:00 PM & 140 & - & - & - & - & -10.2 & - & -74 & - \\
\hline 08/08/2002 & 12:00 PM & 45 & 1.2 & - & -0.4 & - & -10.6 & - & -80 & - \\
\hline 08/08/2002 & 1:30 PM & 113 & 2.2 & - & 0.3 & - & -10.4 & - & -75 & - \\
\hline $11 / 04 / 2002$ & 3:20 PM & 55 & 0.1 & - & 2.4 & - & -8.8 & - & -71 & - \\
\hline $11 / 04 / 2002$ & 3:50 PM & 10 & 2.3 & - & 2.0 & - & -9.4 & - & -73 & - \\
\hline $01 / 28 / 2003$ & 4:40 PM & 140 & 2.1 & - & 0.4 & - & -10.1 & - & -79 & - \\
\hline $01 / 29 / 2003$ & 2:30 PM & 10 & 1.6 & - & 1.5 & - & -9.7 & - & -71 & -71 \\
\hline 04/16/2003 & 4:00 PM & 150 & 1.3 & - & 0.6 & - & -10.6 & -10.6 & -77 & - \\
\hline 08/05/2003 & 12:30 PM & 1 & 1.3 & - & 0.9 & - & -10.3 & - & -70 & - \\
\hline 08/05/2003 & 1:00 PM & 120 & 2.1 & - & 0.4 & 0.5 & -10.3 & - & -75 & -74 \\
\hline 08/05/2003 & 3:30 PM & 73 & 2.1 & - & -0.4 & - & -10.4 & - & -75 & - \\
\hline
\end{tabular}

Site 3, MRS: Middle Reservoir, Shallow (Camp Far West Reservoir east shoreline 1.6 miles above dam)

Station number 390244121171801

\begin{tabular}{|c|c|c|c|c|c|c|c|c|c|}
\hline $10 / 29 / 2001$ & 4:15 PM & 6 & 2.5 & - & 2.4 & - & -8.2 & - & -68 \\
\hline $02 / 12 / 2002$ & 1:30 PM & 60 & 2.3 & - & 1.4 & - & -9.8 & - & -72 \\
\hline $04 / 22 / 2002$ & 1:50 PM & 10 & - & - & 0.0 & - & -10.1 & - & -74 \\
\hline $04 / 15 / 2003$ & 12:40 PM & 32 & 1.6 & - & 1.6 & 1.2 & -10.0 & - & -74 \\
\hline
\end{tabular}

Site 4, MRT: Middle Reservoir, Thalweg (Camp Far West Reservoir in thalweg 1.5 miles above dam)

Station number 390238121173101

\begin{tabular}{|c|c|c|c|c|c|c|c|c|c|}
\hline $10 / 29 / 2001$ & 2:45 PM & 50 & 3.3 & - & 2.9 & - & -8.3 & - & -69 \\
\hline 02/13/2002 & 8:30 AM & 120 & - & - & 0.6 & - & -10.5 & - & -76 \\
\hline $04 / 22 / 2002$ & 12:20 PM & 120 & - & - & 0.8 & - & -10.3 & - & -76 \\
\hline 08/07/2002 & 12:10 PM & 10 & -0.6 & - & -0.2 & - & -9.1 & - & -73 \\
\hline 08/07/2002 & 12:40 PM & 47 & 1.2 & - & 0.0 & - & -10.5 & - & -79 \\
\hline 08/08/2002 & 2:50 PM & 80 & 0.9 & 0.4 & 0.2 & - & -10.6 & - & -77 \\
\hline $11 / 05 / 2002$ & 2:10 PM & 30 & -0.9 & - & 2.5 & - & -8.7 & -8.8 & -71 \\
\hline $11 / 05 / 2002$ & 2:30 PM & 10 & 1.9 & 1.6 & 2.3 & - & -8.8 & - & -71 \\
\hline $01 / 28 / 2003$ & 3:30 PM & 120 & 2.3 & - & 0.3 & - & -10.5 & - & -78 \\
\hline 01/29/2003 & 2:00 PM & 10 & 2.0 & - & 0.9 & - & -10.0 & - & -74 \\
\hline 04/17/2003 & 10:30 AM & 125 & 1.9 & - & 0.8 & - & -10.4 & - & -77 \\
\hline 08/07/2003 & 11:30 AM & 1 & 1.0 & - & -0.4 & - & -9.2 & - & -69 \\
\hline 08/07/2003 & $11: 50 \mathrm{AM}$ & 100 & 2.8 & - & 0.4 & - & -10.0 & -10.3 & \\
\hline
\end{tabular}


Table 4. Data for oxygen and sulfur isotopes in aqueous sulfate and oxygen and hydrogen isotopes in water, Camp Far West Reservoir, California.-Continued

$\left[\delta^{34} \mathrm{~S} \mathrm{SO}_{4}\right.$, delta-sulfur-34 in aqueous sulfate; $\delta^{18} \mathrm{O} \mathrm{SO}_{4}$, delta-oxygen-18 in aqueous sulfate; $\delta^{18} \mathrm{O}_{2} \mathrm{O}$, delta-oxygen-18 in water; $\delta \mathrm{D} \mathrm{H}_{2} \mathrm{O}$, delta-deuterium in water. VSMOW, Vienna Standard Mean Ocean Water; CDT, Cañon Diablo Troilite; (1 of 2) and (2 of 2) refer to replicate analyses. ft, foot; permil, per thousand; - , not determined]

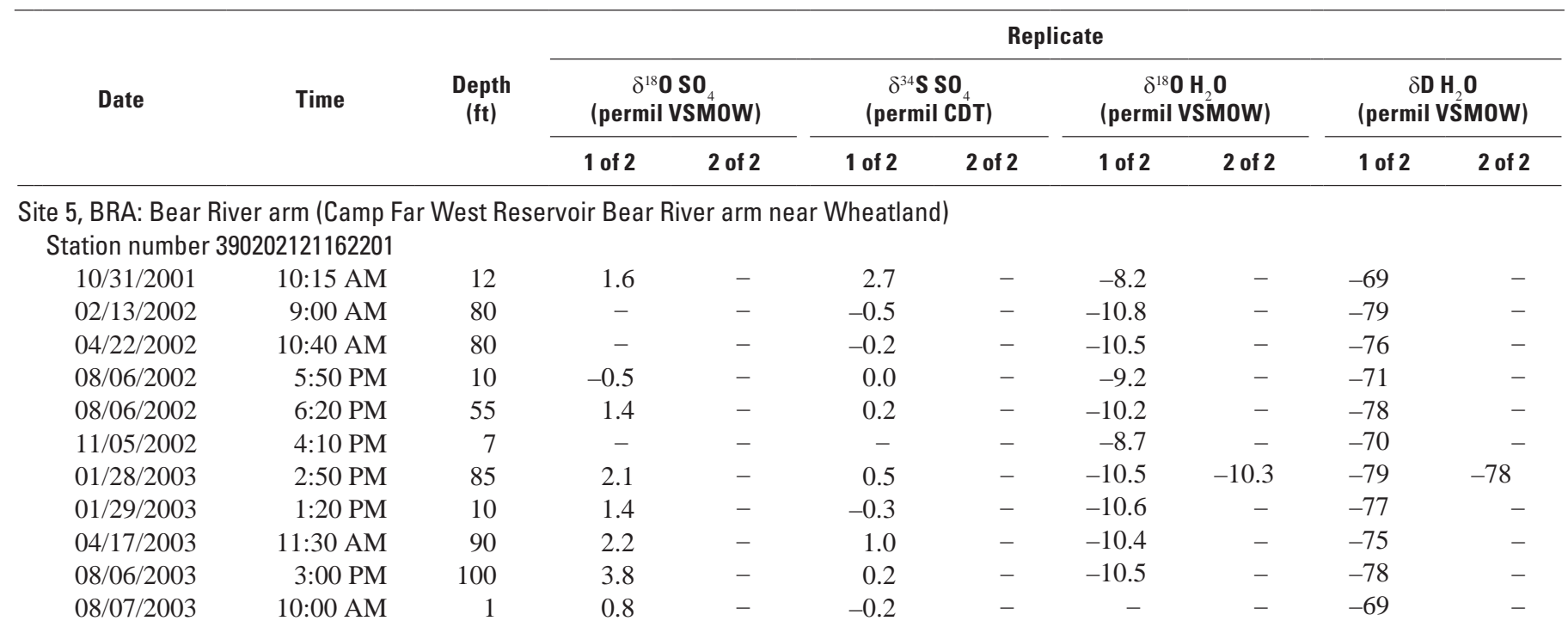

Site 6, DFA: Dairy Farm arm (Camp Far West Reservoir Dairy Farm arm near Wheatland)

Station number 390159121171401

\begin{tabular}{|c|c|c|c|c|c|c|c|c|c|c|}
\hline $10 / 31 / 2001$ & 1:00 PM & 4 & 1.0 & 1.1 & 2.1 & - & -8.2 & -8.2 & -67 & - \\
\hline $02 / 13 / 2002$ & 1:00 PM & 20 & 2.2 & - & 1.3 & - & -9.9 & - & -72 & - \\
\hline $04 / 23 / 2002$ & 12:10 PM & 20 & - & - & -0.2 & - & -10.1 & - & -74 & - \\
\hline 08/07/2002 & $6: 50 \mathrm{PM}$ & 57 & 1.4 & - & 0.0 & - & -10.2 & - & -77 & -76 \\
\hline $01 / 30 / 2003$ & 3:30 PM & 55 & 1.2 & - & 1.5 & - & -10.0 & -10.2 & -74 & - \\
\hline $04 / 17 / 2003$ & 2:30 PM & 55 & 0.7 & - & 1.2 & - & -10.2 & -10.3 & -73 & -75 \\
\hline 08/07/2003 & 4:00 PM & 1 & - & - & - & - & -9.1 & -9.9 & -69 & - \\
\hline
\end{tabular}

Site 7, RCA: Rock Creek arm (Camp Far West Reservoir Rock Creek arm)

Station number 390331121174101

\begin{tabular}{|c|c|c|c|c|c|c|c|c|c|c|}
\hline 08/07/2002 & 3:40 PM & 10 & 0.3 & - & -0.1 & - & -9.1 & - & -71 & - \\
\hline $04 / 17 / 2003$ & 1:20 PM & 80 & 1.7 & - & 1.1 & - & -10.3 & -10.5 & -76 & -77 \\
\hline 08/07/2003 & 1:00 PM & 1 & 1.4 & - & -0.4 & - & -8.9 & - & -67 & - \\
\hline 08/07/2003 & 01:30 PM & 40 & - & - & - & - & -9.9 & - & -73 & - \\
\hline
\end{tabular}

Site 8, DFP: Dairy Farm Mine Pit Lake (Dairy Farm Mine pit lake near Wheatland)

Station number 390148121171701

\begin{tabular}{|c|c|c|c|c|c|c|c|c|c|c|}
\hline $10 / 31 / 2001$ & $2: 15$ PM & 1 & -1.5 & - & 1.3 & - & -4.5 & - & -50 & -51 \\
\hline $02 / 13 / 2002$ & 3:10 PM & 10 & 1.2 & - & 1.2 & - & -9.9 & - & -73 & - \\
\hline $02 / 13 / 2002$ & 3:30 PM & 35 & 0.3 & - & 0.5 & - & - & - & - & - \\
\hline $04 / 24 / 2002$ & 11:10 AM & 30 & - & - & - & - & -10.6 & - & -73 & - \\
\hline 08/07/2002 & 5:00 PM & 0.5 & -1.6 & - & 0.1 & - & -8.7 & - & -69 & - \\
\hline $11 / 05 / 2002$ & $2: 50 \mathrm{PM}$ & 1 & - & - & - & - & -5.6 & - & -54 & - \\
\hline 01/30/2003 & 12:30 PM & 10 & 1.4 & - & 1.1 & - & -9.9 & - & -73 & - \\
\hline 01/30/2003 & 1:20 PM & 38 & - & - & - & - & -9.4 & - & -71 & - \\
\hline $04 / 17 / 2003$ & 4:00 PM & 40 & - & - & - & - & -10.3 & - & -75 & - \\
\hline 08/07/2003 & 4:30 PM & 1 & - & - & - & - & -9.0 & -8.9 & -64 & -70 \\
\hline
\end{tabular}

Site 9, DFI: Dairy Farm Mine Impoundments (Camp Far West Reservoir impoundment Dairy Farm Mine arm) Station number 390152121171001

$\begin{array}{llccccccccc}10 / 31 / 2001 & 2: 40 \text { PM } & 0.5 & -2.3 & - & 0.4 & 0.3 & -8.6 & - & -67 & - \\ 02 / 13 / 2002 & 2: 20 \text { PM } & 52 & 1.6 & - & 0.5 & - & -10.1 & - & -74 & - \\ 04 / 23 / 2002 & 1: 10 \text { PM } & 20 & - & - & - & - & -10.1 & - & -73 & - \\ 11 / 05 / 2002 & 2: 00 \text { PM } & 0.5 & - & - & - & - & -6.2 & - & -54 & -\end{array}$


Table 5. Data for nutrients and organic carbon in water samples, Camp Far West Reservoir, California.

[The number in parentheses is the data parameter code, a five-digit code used in the U.S. Geological Survey computerized data system. Elements: N, nitrogen; P, phosphorus; C, carbon. Thalweg, former river channel (low elevation path). ft, foot; mg/L, milligram per liter; E, estimated; <, less than; - , not determined]

\begin{tabular}{|c|c|c|c|c|c|c|c|c|}
\hline Date & Time & $\begin{array}{c}\text { Depth } \\
\text { (ft) }\end{array}$ & $\begin{array}{c}\text { Nitrogen, } \\
\text { ammonia, } \\
\text { filtered } \\
\text { (mg/L as } \mathrm{N} \text { ) } \\
\text { (00608) }\end{array}$ & $\begin{array}{c}\text { Nitrogen, } \\
\text { ammonia } \\
\text { plus organic, } \\
\text { filtered } \\
\text { (mg/L as } \mathrm{N} \text { ) } \\
(00623)\end{array}$ & $\begin{array}{c}\text { Nitrogen, } \\
\text { ammonia } \\
\text { plus organic, } \\
\text { unfiltered } \\
\text { (mg/L as } \mathrm{N} \text { ) } \\
\text { (00625) }\end{array}$ & $\begin{array}{c}\text { Nitrogen, } \\
\text { nitrite plus } \\
\text { nitrate, } \\
\text { filtered } \\
\text { (mg/L as } \mathrm{N} \text { ) } \\
\text { (00631) }\end{array}$ & $\begin{array}{c}\text { Nitrogen, } \\
\text { nitrite, } \\
\text { filtered } \\
\text { (mg/L as } \mathrm{N} \text { ) } \\
\text { (00613) }\end{array}$ & $\begin{array}{c}\text { Total nitrogen, } \\
\text { particulate } \\
\text { (mg/L) } \\
(49570)\end{array}$ \\
\hline
\end{tabular}

Site 1, LRS: Lower Reservoir, Shallow (Camp Far West Reservoir 0.3 mile north of dam abutment) Station number 390317121185001

\begin{tabular}{|c|c|c|c|c|c|c|c|c|}
\hline $10 / 30 / 2001$ & 5:15 PM & 10 & E0.02 & 0.20 & 0.20 & $<0.05$ & E0.007 & - \\
\hline $02 / 12 / 2002$ & 12:00 PM & 8 & $<0.04$ & 0.18 & 0.28 & 0.37 & $<0.008$ & - \\
\hline $04 / 22 / 2002$ & $3: 20 \mathrm{PM}$ & 10 & $<0.04$ & 0.13 & 0.15 & E0.05 & $<0.008$ & - \\
\hline 08/06/2002 & 4:30 PM & 10 & $<0.04$ & 0.12 & 0.13 & $<0.05$ & $<0.008$ & - \\
\hline $04 / 15 / 2003$ & $10: 30 \mathrm{AM}$ & 40 & $<0.04$ & 0.14 & 0.17 & 0.10 & $<0.008$ & 0.18 \\
\hline
\end{tabular}

Site 2, LRT: Lower Reservoir, Thalweg (Camp Far West Reservoir in thalweg near dam near Wheatland) Station number 390307121183801

$\begin{array}{rrrrllrrr}11 / 01 / 2001 & 8: 30 \mathrm{AM} & 70 & 0.52 & 0.60 & 0.7 & <0.05 & - & - \\ 02 / 12 / 2002 & 11: 00 \mathrm{AM} & 140 & <0.04 & 0.10 & 0.10 & 0.33 & <0.008 & - \\ 04 / 22 / 2002 & 3: 00 \mathrm{PM} & 140 & <0.04 & 0.09 & 0.11 & 0.27 & <0.008 & - \\ 08 / 08 / 2002 & 12: 00 \mathrm{PM} & 45 & <0.04 & 0.084 & 0.11 & \mathrm{E} 0.023 & <0.008 & - \\ 08 / 08 / 2002 & 1: 30 \mathrm{PM} & 113 & <0.04 & 0.089 & 0.11 & 0.36 & <0.008 & - \\ 11 / 04 / 2002 & 3: 50 \mathrm{PM} & 10 & 0.08 & 0.18 & 0.35 & 0.13 & 0.012 & - \\ 11 / 04 / 2002 & 3: 20 \mathrm{PM} & 55 & <0.04 & 0.16 & 0.27 & 0.21 & <0.008 & - \\ 01 / 29 / 2003 & 2: 30 \mathrm{PM} & 10 & <0.04 & 0.15 & 0.25 & 0.34 & <0.008 & 0.08 \\ 01 / 28 / 2003 & 4: 40 \mathrm{PM} & 140 & <0.04 & 0.14 & 0.15 & 0.19 & <0.008 & <0.02 \\ 04 / 16 / 2003 & 4: 00 \mathrm{PM} & 150 & <0.04 & 0.11 & 0.11 & 0.20 & <0.008 & <0.02 \\ 08 / 05 / 2003 & 12: 30 \mathrm{PM} & 1 & <0.04 & 0.10 & 0.17 & <0.06 & <0.008 & 0.05 \\ 08 / 05 / 2003 & 3: 30 \mathrm{PM} & 73 & <0.04 & 0.10 & \mathrm{E} 0.09 & 0.19 & <0.008 & <0.02 \\ 08 / 05 / 2003 & 1: 00 \mathrm{PM} & 120 & <0.04 & 0.10 & 0.12 & 0.32 & <0.008 & 0.05\end{array}$

Site 3, MRS: Middle Reservoir, Shallow (Camp Far West Reservoir east shoreline 1.6 miles above dam) Station number 390244121171801

$\begin{array}{rrrrrrrrr}10 / 29 / 2001 & 4: 15 \text { PM } & 6 & <0.04 & 0.20 & 0.20 & <0.05 & \text { E0.006 } & - \\ 02 / 12 / 2002 & 1: 30 \mathrm{PM} & 60 & <0.04 & 0.16 & 0.29 & 0.37 & <0.008 & - \\ 04 / 22 / 2002 & 1: 50 \mathrm{PM} & 10 & <0.04 & 0.12 & 0.14 & 0.05 & <0.008 & - \\ 04 / 15 / 2003 & 12: 40 \mathrm{PM} & 32 & <0.04 & 0.17 & 0.18 & 0.09 & <0.008 & 0.05\end{array}$

Site 4, MRT: Middle Reservoir, Thalweg (Camp Far West Reservoir in thalweg 1.5 miles above dam) Station number 390238121173101

$\begin{array}{lrrrrrrrr}10 / 29 / 2001 & 2: 45 \mathrm{PM} & 50 & 0.09 & 0.26 & 0.37 & <0.05 & \text { E0.005 } & - \\ 02 / 13 / 2002 & 8: 30 \mathrm{AM} & 120 & <0.04 & 0.12 & 0.15 & \mathrm{E} 0.31 & <0.008 & - \\ 04 / 22 / 2002 & 12: 20 \mathrm{PM} & 120 & <0.04 & \mathrm{E} 0.10 & 0.13 & 0.26 & <0.008 & - \\ 08 / 07 / 2002 & 12: 10 \mathrm{PM} & 10 & <0.04 & 0.12 & 0.17 & <0.05 & <0.008 & - \\ 08 / 07 / 2002 & 12: 40 \mathrm{PM} & 47 & <0.04 & \mathrm{E} 0.08 & 0.10 & \mathrm{E} 0.02 & <0.008 & - \\ 08 / 08 / 2002 & 2: 50 \mathrm{PM} & 80 & <0.04 & \mathrm{E} 0.09 & 0.11 & 0.29 & <0.008 & - \\ 11 / 05 / 2002 & 2: 30 \mathrm{PM} & 10 & \mathrm{E} 0.03 & 0.16 & 0.23 & 0.16 & \mathrm{E} 0.004 & - \\ 11 / 05 / 2002 & 2: 10 \mathrm{PM} & 30 & 0.08 & 0.19 & 0.32 & 0.14 & \mathrm{E} 0.007 & - \\ 01 / 29 / 2003 & 2: 00 \mathrm{PM} & 10 & <0.04 & 0.11 & 0.21 & 0.21 & <0.008 & 0.09 \\ 01 / 28 / 2003 & 3: 30 \mathrm{PM} & 120 & <0.04 & \mathrm{E} 0.08 & 0.10 & 0.18 & <0.008 & <0.02 \\ 04 / 17 / 2003 & 10: 30 \mathrm{AM} & 125 & <0.04 & 0.14 & 0.12 & 0.22 & <0.008 & 0.03 \\ 08 / 07 / 2003 & 11: 30 \mathrm{AM} & 1 & <0.04 & \mathrm{E} 0.08 & 0.14 & <0.06 & <0.008 & 0.05 \\ 08 / 07 / 2003 & 11: 50 \mathrm{AM} & 100 & <0.04 & \mathrm{E} 0.08 & 0.12 & 0.32 & <0.008 & 0.03\end{array}$


Table 5. Data for nutrients and organic carbon in water samples, Camp Far West Reservoir, California._Continued

[The number in parentheses is the data parameter code, a five-digit code used in the U.S. Geological survey computerized data system. Elements: N, nitrogen; P, phosphorus; C, carbon. Thalweg, former river channel (low elevation path). ft, foot; mg/L, milligram per liter; E, estimated; <, less than; - , not determined]

\begin{tabular}{|c|c|c|c|c|c|c|c|c|}
\hline Date & Time & $\begin{array}{c}\text { Depth } \\
\text { (ft) }\end{array}$ & $\begin{array}{c}\text { Nitrogen, } \\
\text { ammonia, } \\
\text { filtered } \\
\text { (mg/L as } \mathrm{N} \text { ) } \\
\text { (00608) }\end{array}$ & $\begin{array}{c}\text { Nitrogen, } \\
\text { ammonia } \\
\text { plus organic, } \\
\text { filtered } \\
\text { (mg/L as } \mathrm{N} \text { ) } \\
\text { (00623) }\end{array}$ & $\begin{array}{c}\text { Nitrogen, } \\
\text { ammonia } \\
\text { plus organic, } \\
\text { unfiltered } \\
\text { (mg/L as } \mathrm{N} \text { ) } \\
(00625)\end{array}$ & $\begin{array}{c}\text { Nitrogen, } \\
\text { nitrite plus } \\
\text { nitrate, } \\
\text { filtered } \\
\text { (mg/L as } \mathrm{N} \text { ) } \\
\text { (00631) }\end{array}$ & $\begin{array}{c}\text { Nitrogen, } \\
\text { nitrite, } \\
\text { filtered } \\
\text { (mg/L as N) } \\
\text { (00613) }\end{array}$ & $\begin{array}{c}\text { Total nitrogen, } \\
\text { particulate } \\
\text { (mg/L) } \\
(49570)\end{array}$ \\
\hline
\end{tabular}

Site 5, BRA: Bear River arm (Camp Far West Reservoir Bear River arm near Wheatland)

Station number 390202121162201

$\begin{array}{lrrrrrrrr}10 / 31 / 2001 & 10: 15 \mathrm{AM} & 12 & 0.15 & 0.31 & 0.37 & \text { E0.02 } & \text { E0.005 } & - \\ 02 / 13 / 2002 & 9: 00 \mathrm{AM} & 80 & <0.04 & \mathrm{E} 0.08 & 0.13 & \mathrm{E} 0.17 & <0.008 & - \\ 04 / 22 / 2002 & 10: 40 \mathrm{AM} & 80 & <0.04 & \mathrm{E} 0.09 & 0.11 & 0.17 & <0.008 & - \\ 08 / 06 / 2002 & 5: 50 \mathrm{PM} & 10 & 0.06 & 0.16 & 0.17 & \mathrm{E} 0.023 & <0.008 & - \\ 08 / 06 / 2002 & 6: 20 \mathrm{PM} & 55 & <0.04 & 0.11 & 0.20 & <0.05 & <0.008 & - \\ 11 / 05 / 2002 & 4: 10 \mathrm{PM} & 7 & 0.05 & 0.25 & 0.57 & 0.13 & \mathrm{E} 0.005 & - \\ 01 / 28 / 2003 & 2: 50 \mathrm{PM} & 85 & <0.04 & \mathrm{E} 0.10 & 0.10 & 0.17 & <0.008 & <0.02 \\ 01 / 29 / 2003 & 1: 20 \mathrm{PM} & 10 & <0.04 & \mathrm{E} 0.06 & \mathrm{E} 0.10 & 0.10 & <0.008 & 0.03 \\ 04 / 17 / 2003 & 11: 30 \mathrm{AM} & 90 & <0.04 & 0.10 & 0.20 & 0.17 & <0.008 & 0.05 \\ 08 / 06 / 2003 & 3: 00 \mathrm{PM} & 100 & 0.11 & 0.20 & 0.51 & \mathrm{E} 0.04 & <0.008 & 0.28 \\ 08 / 07 / 2003 & 10: 00 \mathrm{AM} & 1 & <0.04 & 0.10 & 0.16 & <0.06 & <0.008 & 0.06\end{array}$

Site 6, DFA: Dairy Farm arm (Camp Far West Reservoir Dairy Farm arm near Wheatland)

Station number 390159121171401

$\begin{array}{rrrrrrrrr}10 / 31 / 2001 & 1: 00 \mathrm{PM} & 4 & 0.05 & 0.21 & 0.24 & <0.05 & 0.008 & - \\ 02 / 13 / 2002 & 1: 00 \mathrm{PM} & 20 & <0.04 & 0.15 & 0.18 & \mathrm{E} 0.38 & <0.008 & - \\ 04 / 23 / 2002 & 12: 10 \mathrm{PM} & 20 & <0.04 & 0.14 & 0.18 & \mathrm{E} 0.04 & <0.008 & - \\ 08 / 07 / 2002 & 6: 50 \mathrm{PM} & 57 & <0.04 & 0.10 & 0.15 & <0.05 & \mathrm{E} 0.004 & - \\ 01 / 30 / 2003 & 3: 30 \mathrm{PM} & 55 & <0.04 & \mathrm{E} 0.09 & 0.16 & 0.21 & <0.008 & 0.13 \\ 04 / 17 / 2003 & 2: 30 \mathrm{PM} & 55 & <0.04 & 0.13 & 0.14 & 0.11 & <0.008 & - \\ 08 / 07 / 2003 & 4: 00 \mathrm{PM} & 1 & <0.04 & 0.10 & 0.17 & <0.06 & <0.008 & 0.05\end{array}$

Site 7, RCA: Rock Creek arm (Camp Far West Reservoir Rock Creek arm)

Station number 390331121174101

$\begin{array}{llrlrrrrr}08 / 07 / 2002 & 3: 40 \text { PM } & 10 & <0.04 & 0.10 & 0.20 & <0.05 & \text { E0.004 } \\ 04 / 17 / 2003 & 1: 20 \text { PM } & 80 & <0.04 & 0.10 & 0.10 & 0.17 & <0.008 & 0.57 \\ 08 / 07 / 2003 & 1: 00 \text { PM } & 1 & <0.04 & \text { E0.10 } & 0.20 & <0.06 & <0.008 & - \\ 08 / 07 / 2003 & 1: 30 \mathrm{PM} & 40 & <0.04 & \text { E0.07 } & 0.18 & <0.06 & <0.008 & -\end{array}$

Site 8, DFP: Dairy Farm Mine Pit Lake (Dairy Farm Mine pit lake near Wheatland)

Station number 390148121171701

\begin{tabular}{|c|c|c|c|c|c|c|c|c|}
\hline $10 / 31 / 2001$ & $2: 15 \mathrm{PM}$ & 1 & 3.3 & 3.2 & 3.3 & 0.12 & $<0.008$ & - \\
\hline $02 / 13 / 2002$ & $3: 10 \mathrm{PM}$ & 10 & $<0.04$ & 0.15 & 0.25 & 0.39 & $<0.008$ & - \\
\hline $02 / 13 / 2002$ & 3:30 PM & 35 & E0.02 & 0.14 & 0.18 & 0.35 & $<0.008$ & - \\
\hline $04 / 24 / 2002$ & $11: 10 \mathrm{AM}$ & 30 & E0.03 & 0.11 & 0.15 & 0.09 & $<0.008$ & - \\
\hline 08/07/2002 & 5:00 PM & 0.5 & 0.16 & 0.21 & 0.25 & 0.13 & $<0.008$ & - \\
\hline $11 / 05 / 2002$ & $2: 50 \mathrm{PM}$ & 1 & 1.9 & 1.9 & 1.9 & 0.25 & $<0.008$ & - \\
\hline $01 / 30 / 2003$ & $12: 30 \mathrm{PM}$ & 10 & $<0.04$ & 0.12 & 0.29 & 0.23 & $<0.008$ & 0.12 \\
\hline $01 / 30 / 2003$ & 1:20 PM & 38 & 0.15 & 0.20 & 0.20 & 0.49 & E0.004 & - \\
\hline $04 / 17 / 2003$ & 4:00 PM & 40 & 0.41 & 0.50 & 0.50 & 0.13 & $<0.008$ & $<0.02$ \\
\hline 08/07/2003 & 4:30 PM & 1 & E0.02 & E0.08 & 0.24 & 0.08 & $<0.008$ & 0.03 \\
\hline
\end{tabular}

Site 9, DFI: Dairy Farm Mine Impoundments (Camp Far West Reservoir impoundment Dairy Farm Mine arm) Station number 390152121171001

\begin{tabular}{llccccccc}
$10 / 31 / 2001$ & $2: 40$ PM & 0.5 & - & - & - & - & - & - \\
$02 / 13 / 2002$ & $2: 20$ PM & 52 & E0.03 & 0.13 & 0.18 & 0.36 & $<0.008$ & - \\
$04 / 23 / 2002$ & $1: 10$ PM & 20 & $<0.04$ & 0.15 & 0.16 & E0.04 & $<0.008$ & - \\
$11 / 05 / 2002$ & $2: 00$ PM & 0.5 & 1.5 & 1.6 & 1.6 & E0.04 & $<0.008-$ & - \\
\hline
\end{tabular}


Table 5. Data for nutrients and organic carbon in water samples, Camp Far West Reservoir, California._Continued

[The number in parentheses is the data parameter code, a five-digit code used in the U.S. Geological survey computerized data system. Elements: N, nitrogen; P, phosphorus; C, carbon. Thalweg, former river channel (low elevation path). ft, foot; mg/L, milligram per liter; E, estimated; <, less than; - , not determined]

\begin{tabular}{|c|c|c|c|c|c|c|c|c|c|}
\hline Date & Time & $\begin{array}{c}\text { Depth } \\
\text { (ft) }\end{array}$ & $\begin{array}{c}\text { Total } \\
\text { phosphorus, } \\
\text { filtered } \\
\text { (mg/L as P) } \\
(00666)\end{array}$ & $\begin{array}{c}\text { Phosphorus, } \\
\text { orthophosphate, } \\
\text { filtered } \\
\text { (mg/L as } \mathrm{P} \text { ) } \\
\text { (00671) }\end{array}$ & $\begin{array}{c}\text { Total } \\
\text { phosphorus, } \\
\text { unfiltered } \\
\text { (mg/L as } \mathrm{P}) \\
\text { (00665) }\end{array}$ & $\begin{array}{c}\text { Carbon, } \\
\text { inorganic } \\
\text { plus organic, } \\
\text { particulate } \\
\text { (mg/L as C) } \\
\text { (00694) }\end{array}$ & $\begin{array}{c}\text { Total } \\
\text { carbon, } \\
\text { inorganic, } \\
\text { particulate } \\
\text { (mg/L as C) } \\
\text { (00688) }\end{array}$ & $\begin{array}{c}\text { Carbon, } \\
\text { organic, } \\
\text { filtered } \\
\text { (mg/L as C) } \\
\text { (00681) }\end{array}$ & $\begin{array}{c}\text { Carbon, } \\
\text { organic, } \\
\text { particulate } \\
\text { (mg/L as C) } \\
(00689)\end{array}$ \\
\hline \multicolumn{10}{|c|}{ Site 1, LRS: Lower Reservoir, Shallow (Camp Far West Reservoir 0.3 mile north of dam abutment) } \\
\hline $10 / 30 / 2001$ & $5: 15 \mathrm{PM}$ & 10 & 0.005 & $<0.02$ & 0.015 & - & - & 2.3 & 0.2 \\
\hline $02 / 12 / 2002$ & 12:00 PM & 8 & 0.006 & $<0.02$ & 0.021 & - & - & 3.0 & 0.3 \\
\hline $04 / 22 / 2002$ & 3:20 PM & 10 & $<0.004$ & $<0.02$ & 0.014 & - & - & 2.1 & $<0.2$ \\
\hline 08/06/2002 & 4:30 PM & 10 & $<0.004$ & $<0.02$ & 0.012 & - & - & 2.5 & 0.6 \\
\hline 04/15/2003 & 10:30 AM & 40 & 0.006 & $<0.02$ & 0.018 & 0.8 & $<0.1$ & 2.6 & 0.8 \\
\hline \multicolumn{10}{|c|}{ Site 2, LRT: Lower Reservoir, Thalweg (Camp Far West Reservoir in thalweg near dam near Wheatland) } \\
\hline \multicolumn{10}{|c|}{ Station number 390307121183801} \\
\hline $11 / 01 / 2001$ & 8:30 AM & 70 & 0.006 & - & 0.024 & - & - & - & 0.8 \\
\hline $02 / 12 / 2002$ & 11:00 AM & 140 & 0.007 & $<0.02$ & 0.016 & - & - & 2.3 & $<0.2$ \\
\hline $04 / 22 / 2002$ & 3:00 PM & 140 & 0.009 & $<0.02$ & 0.018 & - & - & 2.1 & $<0.2$ \\
\hline 08/08/2002 & 12:00 PM & 45 & E0.002 & $<0.02$ & 0.0076 & - & - & 2.0 & 0.32 \\
\hline 08/08/2002 & 1:30 PM & 113 & E0.003 & $<0.02$ & 0.0089 & - & - & 1.5 & 0.21 \\
\hline $11 / 04 / 2002$ & 3:20 PM & 55 & E0.004 & $<0.02$ & 0.022 & - & - & 2.4 & 0.4 \\
\hline $11 / 04 / 2002$ & 3:50 PM & 10 & E0.003 & $<0.02$ & 0.034 & - & - & 2.0 & 0.5 \\
\hline $01 / 28 / 2003$ & 4:40 PM & 140 & 0.007 & $<0.02$ & 0.012 & $<0.1$ & $<0.1$ & 1.7 & $<0.1$ \\
\hline $01 / 29 / 2003$ & 2:30 PM & 10 & 0.006 & $<0.02$ & 0.018 & 0.4 & $<0.1$ & 2.6 & 0.4 \\
\hline $04 / 16 / 2003$ & 4:00 PM & 150 & 0.006 & $<0.02$ & 0.012 & $<0.1$ & $<0.1$ & 1.9 & $<0.1$ \\
\hline 08/05/2003 & 12:30 PM & 1 & E0.003 & $<0.02$ & 0.008 & 0.3 & $<0.1$ & 2.0 & 0.3 \\
\hline 08/05/2003 & 1:00 PM & 120 & 0.009 & $<0.02$ & 0.014 & 0.2 & $<0.1$ & 2.1 & 0.2 \\
\hline $08 / 05 / 2003$ & 3:30 PM & 73 & E0.004 & $<0.02$ & 0.008 & $<0.1$ & $<0.1$ & 1.7 & $<0.1$ \\
\hline
\end{tabular}

Site 3, MRS: Middle Reservoir, Shallow (Camp Far West Reservoir east shoreline 1.6 miles above dam)

Station number 390244121171801

\begin{tabular}{|c|c|c|c|c|c|c|c|c|}
\hline $10 / 29 / 2001$ & 4:15 PM & 6 & E0.004 & $<0.02$ & 0.014 & - & - & 2.6 \\
\hline $02 / 12 / 2002$ & 1:30 PM & 60 & E0.004 & $<0.02$ & 0.023 & - & - & 3.0 \\
\hline $04 / 22 / 2002$ & 1:50 PM & 10 & $<0.004$ & $<0.02$ & 0.013 & - & - & 1.8 \\
\hline $04 / 15 / 2003$ & 12:40 PM & 32 & 0.009 & $<0.02$ & 0.010 & 0.3 & $<0.1$ & 2.8 \\
\hline
\end{tabular}

Site 4, MRT: Middle Reservoir, Thalweg (Camp Far West Reservoir in thalweg 1.5 miles above dam)

Station number 390238121173101

\begin{tabular}{|c|c|c|c|c|c|c|c|c|c|}
\hline $10 / 29 / 2001$ & 2:45 PM & 50 & 0.006 & $<0.02$ & 0.051 & - & - & 2.4 & 0.4 \\
\hline $02 / 13 / 2002$ & 8:30 AM & 120 & 0.010 & $<0.02$ & 0.015 & - & - & 2.3 & $<0.2$ \\
\hline $04 / 22 / 2002$ & 12:20 PM & 120 & 0.012 & E0.01 & 0.017 & - & - & 2.0 & $<0.2$ \\
\hline 08/07/2002 & 12:10 PM & 10 & E0.003 & $<0.02$ & 0.011 & - & - & 2.2 & 0.5 \\
\hline 08/07/2002 & $12: 40 \mathrm{PM}$ & 47 & E0.003 & $<0.02$ & 0.008 & - & - & 2.0 & 0.3 \\
\hline 08/08/2002 & 2:50 PM & 80 & E0.003 & $<0.02$ & 0.009 & - & - & 1.5 & 0.2 \\
\hline $11 / 05 / 2002$ & 2:10 PM & 30 & 0.005 & $<0.02$ & 0.035 & - & - & 2.3 & 0.6 \\
\hline $11 / 05 / 2002$ & 2:30 PM & 10 & 0.005 & $<0.02$ & 0.025 & - & - & 2.2 & 0.6 \\
\hline $01 / 28 / 2003$ & 3:30 PM & 120 & 0.007 & $<0.004$ & 0.012 & - & $<0.1$ & 1.7 & $<0.1$ \\
\hline $01 / 29 / 2003$ & 2:00 PM & 10 & 0.005 & $<0.02$ & 0.018 & 0.5 & $<0.1$ & 2.2 & 0.5 \\
\hline $04 / 17 / 2003$ & 10:30 AM & 125 & 0.009 & $<0.02$ & 0.019 & $<0.1$ & $<0.1$ & 1.9 & $<0.1$ \\
\hline 08/07/2003 & 11:30 AM & 1 & E0.003 & $<0.02$ & 0.008 & 0.3 & $<0.1$ & 1.9 & 0.3 \\
\hline 08/07/2003 & $11: 50 \mathrm{AM}$ & 100 & 0.007 & $<0.02$ & 0.011 & 0.1 & $<0.1$ & 1.9 & 0.1 \\
\hline
\end{tabular}


Table 5. Data for nutrients and organic carbon in water samples, Camp Far West Reservoir, California._Continued

[The number in parentheses is the data parameter code, a five-digit code used in the U.S. Geological survey computerized data system. Elements: N, nitrogen; P, phosphorus; C, carbon. Thalweg, former river channel (low elevation path). ft, foot; mg/L, milligram per liter; E, estimated; <, less than;

- , not determined]

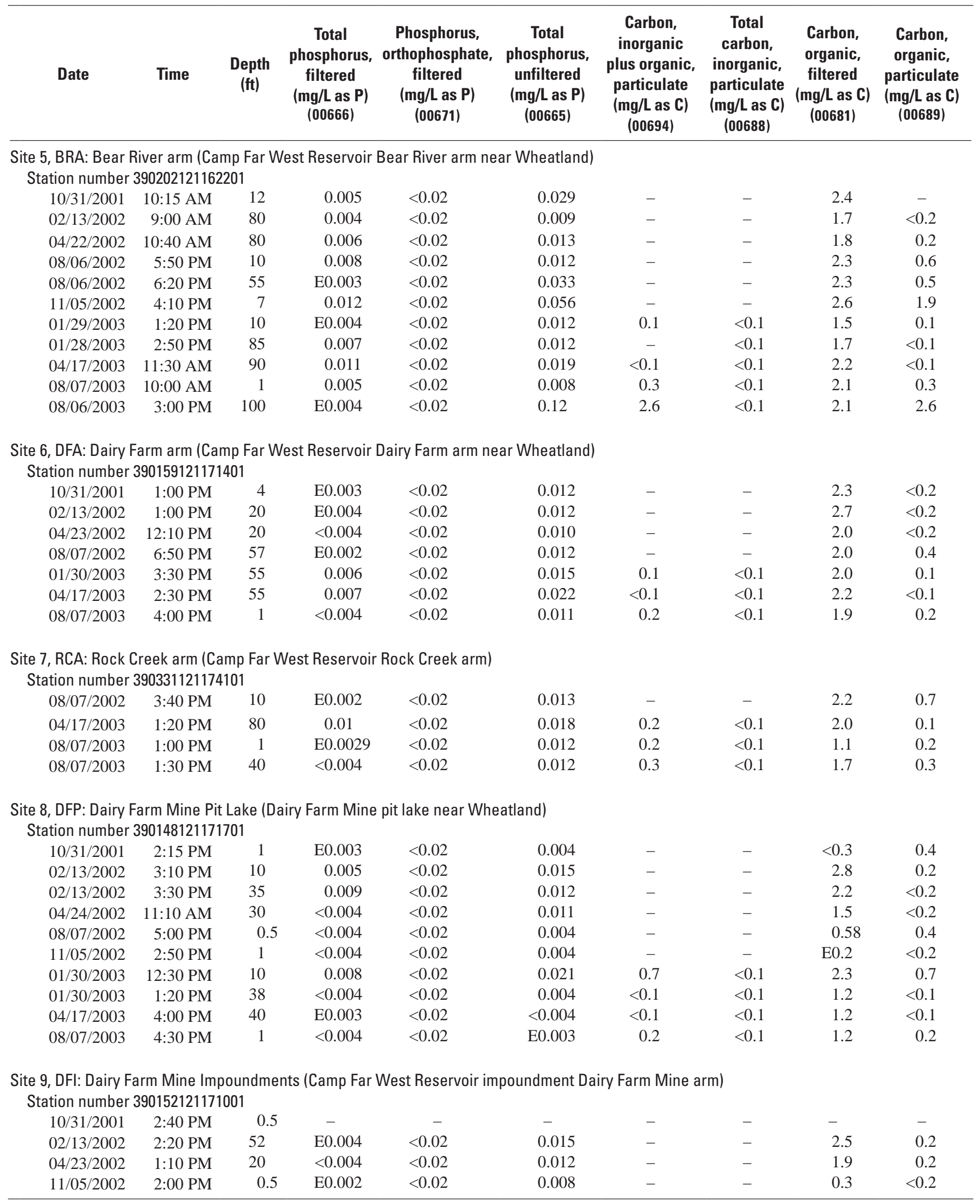


Table 6. Best values for concentrations of total mercury in water samples, Camp Far West Reservoir, California.

[The number in parentheses is the data parameter code, a five-digit code used in the U.S. Geological Survey computerized data system. Source of best values: a, sum of quartz filter filtrate and quartz filter particulates; b, average of two replicates, Boulder, Colo., laboratory (lab); c, weighted average of two replicates, Boulder lab, and one replicate, Wisconsin lab; d, Wisconsin lab, single sample; e, Boulder lab, single sample; f, quartz filter filtrate; g, quartz filter particulates; h, difference of filtered and unfiltered best values. Thalweg, former river channel (low elevation path). ft, foot; Hg, mercury; ng/L, nanogram per liter]

\begin{tabular}{|c|c|c|c|c|c|c|c|c|}
\hline \multirow[t]{2}{*}{ Date } & \multirow[t]{2}{*}{ Time } & \multirow[t]{2}{*}{ Depth (ft) } & \multicolumn{2}{|c|}{$\begin{array}{c}\text { Unfiltered total Hg } \\
\text { (ng/L) } \\
(\mathbf{5 0 2 8 6 )}\end{array}$} & \multicolumn{2}{|c|}{$\begin{array}{c}\text { Filtered total } \mathrm{Hg} \\
(\mathbf{n g} / \mathbf{L}) \\
(\mathbf{5 0 2 8 7})\end{array}$} & \multicolumn{2}{|c|}{$\begin{array}{l}\text { Particulate total } \mathrm{Hg} \\
\text { (ng/L) }\end{array}$} \\
\hline & & & Value & Source & Value & Source & Value & Source \\
\hline \multicolumn{9}{|c|}{ Site 1, LRS: Lower Reservoir, Shallow (Camp Far West Reservoir 0.3 mile north of dam abutment) } \\
\hline \multicolumn{9}{|c|}{ Station number 390317121185001} \\
\hline $10 / 30 / 2001$ & 5:15 PM & 10 & 6.2 & a & 0.8 & $\mathrm{f}$ & 5.4 & g \\
\hline $02 / 12 / 2002$ & 12:00 PM & 8 & 5.4 & $\mathrm{~b}$ & 1.8 & $\mathrm{~b}$ & 3.7 & $\mathrm{~h}$ \\
\hline $04 / 22 / 2002$ & $3: 20 \mathrm{PM}$ & 10 & 2.4 & $\mathrm{~b}$ & 0.9 & $\mathrm{~b}$ & 1.5 & $\mathrm{~h}$ \\
\hline 08/06/2002 & 4:30 PM & 10 & 1.6 & $\mathrm{~b}$ & 0.4 & $\mathrm{~b}$ & 1.2 & $\mathrm{~h}$ \\
\hline $04 / 15 / 2003$ & $10: 30 \mathrm{AM}$ & 40 & 3.9 & $\mathrm{~d}$ & 1.0 & d & 2.9 & $\mathrm{~h}$ \\
\hline
\end{tabular}

Site 2, LRT: Lower Reservoir, Thalweg (Camp Far West Reservoir in thalweg near dam near Wheatland)

Station number 390307121183801

\begin{tabular}{|c|c|c|c|c|c|c|c|}
\hline $11 / 01 / 2001$ & 8:30 AM & 70 & 12.1 & $\mathrm{a}$ & 2.5 & $\mathrm{f}$ & 9.6 \\
\hline $02 / 12 / 2002$ & 11:00 AM & 140 & 7.8 & $\mathrm{~b}$ & 1.5 & $\mathrm{~b}$ & 6.4 \\
\hline $04 / 22 / 2002$ & 3:00 PM & 140 & 4.3 & b & 1.1 & $\mathrm{~b}$ & 3.2 \\
\hline 08/08/2002 & 12:00 PM & 45 & 1.9 & b & 0.3 & $\mathrm{~b}$ & 1.7 \\
\hline 08/08/2002 & 1:30 PM & 113 & 1.8 & b & 0.6 & $\mathrm{~b}$ & 1.2 \\
\hline $11 / 04 / 2002$ & 3:50 PM & 10 & 8.2 & $\mathrm{c}$ & 0.3 & $\mathrm{~d}$ & 7.9 \\
\hline $11 / 04 / 2002$ & 3:20 PM & 55 & 5.6 & $\mathrm{c}$ & 0.3 & $\mathrm{~d}$ & 5.3 \\
\hline $01 / 29 / 2003$ & 2:30 PM & 10 & 5.7 & $\mathrm{c}$ & 1.7 & $\mathrm{c}$ & 4.0 \\
\hline $01 / 28 / 2003$ & 4:40 PM & 140 & 7.1 & $\mathrm{c}$ & 1.5 & $\mathrm{c}$ & 5.6 \\
\hline $04 / 16 / 2003$ & 4:00 PM & 150 & 2.9 & d & 0.9 & d & 2.0 \\
\hline $08 / 05 / 2003$ & 12:30 PM & 1 & 2.5 & d & 0.4 & d & 2.1 \\
\hline 08/05/2003 & 3:30 PM & 73 & 3.3 & $\mathrm{~d}$ & 0.7 & $\mathrm{~d}$ & 2.6 \\
\hline 08/05/2003 & 1:00 PM & 120 & 2.1 & d & 0.9 & $\mathrm{~d}$ & 1.2 \\
\hline
\end{tabular}

Site 3, MRS: Middle Reservoir, Shallow (Camp Far West Reservoir east shoreline 1.6 miles above dam) Station number 390244121171801

$\begin{array}{lrrllllll}10 / 29 / 2001 & 4: 15 \text { PM } & 6 & 4.1 & \text { a } & 0.6 & \text { f } & 3.5 & \text { h } \\ 02 / 12 / 2002 & 1: 30 \text { PM } & 60 & 4.9 & \text { b } & 1.7 & \text { b } & 3.3 & \text { h } \\ 04 / 22 / 2002 & 1: 50 \text { PM } & 10 & 2.7 & \text { b } & 0.9 & \text { b } & 1.8 & \text { h } \\ 04 / 15 / 2003 & 12: 40 \text { PM } & 32 & 2.4 & \text { d } & 0.9 & \text { d } & 1.4 & \text { h }\end{array}$

Site 4, MRT: Middle Reservoir, Thalweg (Camp Far West Reservoir in thalweg 1.5 miles above dam)

Station number 390238121173101

$\begin{array}{lrrrrrrrr}10 / 29 / 2001 & 2: 45 \mathrm{PM} & 50 & 12.6 & \mathrm{a} & 1.0 & \mathrm{f} & 11.6 & \mathrm{~g} \\ 02 / 13 / 2002 & 8: 30 \mathrm{AM} & 120 & 8.0 & \mathrm{~b} & 1.3 & \mathrm{~b} & 6.7 & \mathrm{~h} \\ 04 / 22 / 2002 & 12: 20 \mathrm{PM} & 120 & 4.5 & \mathrm{~b} & 1.0 & \mathrm{~b} & 3.5 & \mathrm{~h} \\ 08 / 07 / 2002 & 12: 10 \mathrm{PM} & 10 & 1.7 & \mathrm{~b} & 0.4 & \mathrm{~b} & 1.3 & \mathrm{~h} \\ 08 / 07 / 2002 & 12: 40 \mathrm{PM} & 47 & 1.0 & \mathrm{~b} & 0.3 & \mathrm{~b} & 0.7 & \mathrm{~h} \\ 08 / 08 / 2002 & 2: 50 \mathrm{PM} & 80 & 2.6 & \mathrm{~b} & 0.4 & \mathrm{~b} & 2.2 & \mathrm{~h} \\ 11 / 05 / 2002 & 2: 30 \mathrm{PM} & 10 & 4.7 & \mathrm{c} & 0.3 & \mathrm{c} & 4.3 & \mathrm{~h} \\ 11 / 05 / 2002 & 2: 10 \mathrm{PM} & 30 & 10.4 & \mathrm{c} & 0.3 & \mathrm{c} & 10.1 & \mathrm{~h} \\ 01 / 29 / 2003 & 2: 00 \mathrm{PM} & 10 & 4.9 & \mathrm{c} & 1.6 & \mathrm{c} & 3.3 & \mathrm{~h} \\ 01 / 28 / 2003 & 3: 30 \mathrm{PM} & 120 & 7.0 & \mathrm{c} & 1.5 & \mathrm{c} & 5.5 & \mathrm{~h} \\ 04 / 17 / 2003 & 10: 30 \mathrm{AM} & 125 & 3.8 & \mathrm{~d} & 0.9 & \mathrm{~d} & 2.9 & \mathrm{~h} \\ 08 / 07 / 2003 & 11: 30 \mathrm{AM} & 1 & 1.2 & \mathrm{~d} & 1.0 & \mathrm{~d} & 0.2 & \mathrm{~h} \\ 08 / 07 / 2003 & 11: 50 \mathrm{AM} & 100 & 2.8 & \mathrm{~d} & 0.7 & \mathrm{~d} & 2.1 & \mathrm{~h}\end{array}$


Table 6. Best values for total mercury concentrations, Camp Far West Reservoir, California._Continued

[The number in parentheses is the data parameter code, a five-digit code used in the U.S. Geological Survey computerized data system. Source of best values: a, sum of quartz filter filtrate and quartz filter particulates; b, average of two replicates, Boulder, Colo., laboratory (lab); c, weighted average of two replicates, Boulder lab, and one replicate, Wisconsin lab; d, Wisconsin lab, single sample; e, Boulder lab, single sample; f, quartz filter filtrate; g, quartz filter particulates; h, difference of filtered and unfiltered "best values.” Thalweg, former river channel (low elevation path). ft, foot; Hg, mercury; ng/L, nanogram per liter]

\begin{tabular}{|c|c|c|c|c|c|c|c|c|}
\hline \multirow[t]{2}{*}{ Date } & \multirow[t]{2}{*}{ Time } & \multirow[t]{2}{*}{ Depth (ft) } & \multicolumn{2}{|c|}{$\begin{array}{l}\text { Unfiltered total } \mathrm{Hg} \\
\text { (ng/L) } \\
(\mathbf{5 0 2 8 6 )}\end{array}$} & \multicolumn{2}{|c|}{$\begin{array}{c}\text { Filtered total } \mathrm{Hg} \\
\text { (ng/L) } \\
(\mathbf{5 0 2 8 7})\end{array}$} & \multicolumn{2}{|c|}{$\begin{array}{l}\text { Particulate total } \mathrm{Hg} \\
\text { (ng/L) }\end{array}$} \\
\hline & & & Value & Source & Value & Source & Value & Source \\
\hline
\end{tabular}

Site 5, BRA: Bear River arm (Camp Far West Reservoir Bear River arm near Wheatland)

Station number 390202121162201

\begin{tabular}{|c|c|c|c|c|c|c|c|}
\hline $10 / 31 / 2001$ & 10:15 AM & 12 & 9.7 & $\mathrm{a}$ & 0.6 & $\mathrm{~b}$ & 9.2 \\
\hline $02 / 13 / 2002$ & 9:00 AM & 80 & 8.5 & $\mathrm{~b}$ & 1.4 & $\mathrm{~b}$ & 7.2 \\
\hline $04 / 22 / 2002$ & 10:40 AM & 80 & 4.6 & $\mathrm{~b}$ & 0.8 & $\mathrm{~b}$ & 3.8 \\
\hline 08/06/2002 & 5:50 PM & 10 & 1.5 & $\mathrm{~b}$ & 0.5 & $\mathrm{~b}$ & 1.1 \\
\hline 08/06/2002 & 6:20 PM & 55 & 3.2 & $\mathrm{~b}$ & 0.4 & $\mathrm{~b}$ & 2.8 \\
\hline $11 / 05 / 2002$ & 4:10 PM & 7 & 4.8 & $\mathrm{c}$ & 0.3 & $\mathrm{c}$ & 4.5 \\
\hline 01/29/2003 & 1:20 PM & 10 & 6.9 & $\mathrm{c}$ & 1.6 & $\mathrm{c}$ & 5.3 \\
\hline $01 / 28 / 2003$ & 2:50 PM & 85 & 6.9 & $\mathrm{c}$ & 1.5 & $\mathrm{c}$ & 5.4 \\
\hline 04/17/2003 & 11:30 AM & 90 & 6.0 & d & 1.4 & $\mathrm{~d}$ & 4.6 \\
\hline 08/07/2003 & 10:00 AM & 1 & 1.4 & d & 0.4 & $\mathrm{~d}$ & 1.0 \\
\hline 08/06/2003 & 3:00 PM & 100 & 43.6 & d & 0.6 & $d$ & 43 \\
\hline
\end{tabular}

Site 6, DFA: Dairy Farm arm (Camp Far West Reservoir Dairy Farm arm near Wheatland)

Station number 390159121171401

$\begin{array}{lrrrrr}10 / 31 / 2001 & 1: 00 \mathrm{PM} & 4 & 3.9 & \mathrm{a} & 0.7 \\ 02 / 13 / 2002 & 1: 00 \mathrm{PM} & 20 & 6.3 & \mathrm{~b} & 1.6 \\ 04 / 23 / 2002 & 12: 10 \mathrm{PM} & 20 & 2.5 & \mathrm{e} & 1.0 \\ 08 / 07 / 2002 & 6: 50 \mathrm{PM} & 57 & 2.8 & \mathrm{~b} & 0.4 \\ 01 / 30 / 2003 & 3: 30 \mathrm{PM} & 55 & 7.3 & \mathrm{c} & 1.8 \\ 04 / 17 / 2003 & 2: 30 \mathrm{PM} & 55 & 5.2 & \mathrm{~d} & 1.5 \\ 08 / 07 / 2003 & 4: 00 \mathrm{PM} & 1 & 1.8 & \mathrm{~d} & 0.4\end{array}$

Site 7, RCA: Rock Creek arm (Camp Far West Reservoir Rock Creek arm)

Station number 390331121174101

$\begin{array}{llrllllll}08 / 07 / 2002 & 03: 40 \text { PM } & 10 & 1.6 & \text { b } & 0.3 & \text { b } & 1.3 & \text { h } \\ 04 / 17 / 2003 & 01: 20 \text { PM } & 80 & 4.0 & \text { d } & 0.9 & \text { d } & 3.1 & \text { h } \\ 08 / 07 / 2003 & 01: 00 \text { PM } & 1 & 1.5 & \text { d } & 0.4 & \text { d } & 1.1 & \text { h } \\ 08 / 07 / 2003 & 01: 30 \text { PM } & 40 & 2.5 & \text { d } & 0.5 & \text { d } & 2.0 & \text { h }\end{array}$

Site 8, DFP: Dairy Farm Mine Pit Lake (Dairy Farm Mine pit lake near Wheatland)

Station number 390148121171701

$\begin{array}{lrrrlllll}10 / 31 / 2001 & 2: 15 \text { PM } & 1 & 10.8 & \mathrm{a} & 5.3 & \mathrm{f} & 5.5 & \mathrm{~g} \\ 02 / 13 / 2002 & 3: 10 \text { PM } & 10 & 5.8 & \mathrm{~b} & 3.6 & \mathrm{f} & 2.3 & \mathrm{~h} \\ 02 / 13 / 2002 & 3: 30 \mathrm{PM} & 35 & 6.4 & \mathrm{~b} & 3.2 & \mathrm{f} & 3.2 & \mathrm{~h} \\ 04 / 24 / 2002 & 11: 10 \mathrm{AM} & 30 & 3.2 & \mathrm{~b} & 0.8 & \mathrm{~b} & 2.5 & \mathrm{~h} \\ 08 / 07 / 2002 & 5: 00 \mathrm{PM} & 0.5 & 3.1 & \mathrm{~b} & 0.2 & \mathrm{~b} & 2.9 & \mathrm{~h} \\ 11 / 05 / 2002 & 2: 50 \mathrm{PM} & 1 & 4.3 & \mathrm{~b} & 1.4 & \mathrm{~b} & 2.9 & \mathrm{~h} \\ 01 / 30 / 2003 & 12: 30 \mathrm{PM} & 10 & 1.2 & \mathrm{c} & 0.3 & \mathrm{c} & 0.9 & \mathrm{~h} \\ 01 / 30 / 2003 & 1: 20 \mathrm{PM} & 38 & 4.6 & \mathrm{c} & 1.7 & \mathrm{c} & 2.9 & \mathrm{~h} \\ 04 / 17 / 2003 & 4: 00 \mathrm{PM} & 40 & 1.0 & \mathrm{~d} & 0.4 & \mathrm{~d} & 0.6 & \mathrm{~h} \\ 08 / 07 / 2003 & 4: 30 \mathrm{PM} & 1 & 7.0 & \mathrm{~d} & 0.1 & \mathrm{~d} & 6.9 & \mathrm{~h}\end{array}$

Site 9, DFI: Dairy Farm Mine Impoundments (Camp Far West Reservoir impoundment Dairy Farm Mine arm)

Station number 390152121171001

\begin{tabular}{llcllllll}
$10 / 31 / 2001$ & $2: 40$ PM & 0.5 & 5.3 & $\mathrm{a}$ & 2.1 & $\mathrm{f}$ & 3.2 & $\mathrm{~g}$ \\
$02 / 13 / 2002$ & $2: 20 \mathrm{PM}$ & 52 & 7.1 & $\mathrm{~b}$ & 3.5 & $\mathrm{f}$ & 3.6 & $\mathrm{~h}$ \\
$04 / 23 / 2002$ & $1: 10 \mathrm{PM}$ & 20 & 2.6 & $\mathrm{~b}$ & 1.1 & $\mathrm{f}$ & 1.5 & $\mathrm{~h}$ \\
$11 / 05 / 2002$ & $2: 00 \mathrm{PM}$ & 0.5 & 3.0 & $\mathrm{~b}$ & 0.3 & $\mathrm{~b}$ & 2.7 & $\mathrm{~h}$ \\
\hline
\end{tabular}


Table 7. Data for methylmercury in water samples, Camp Far West Reservoir, California.

[The number in parentheses is the data parameter code, a five-digit code used in the U.S. Geological Survey computerized data system. Thalweg, former river channel (low elevation path). C45, 0.45-micrometer capsule filter; Q, quartz fiber filter; MeHg, methylmercury; ft, foot; ng/L, nanogram per liter; E, estimated. <, less than detection limit; -, not determined]

\begin{tabular}{|c|c|c|c|c|c|c|}
\hline Date & Time & $\begin{array}{c}\text { Depth } \\
\text { (ft) }\end{array}$ & $\begin{array}{c}\text { MeHg } \\
\text { unfiltered } \\
\text { (ng/L) } \\
(\mathbf{5 0 2 8 4 )}\end{array}$ & $\begin{array}{c}\text { MeHg } \\
\text { filtered (C45) } \\
\text { (ng/L) } \\
(\mathbf{5 0 2 8 5 )}\end{array}$ & $\begin{array}{c}\text { MeHg } \\
\text { filtered (0) } \\
\text { (ng/L) } \\
(50285)\end{array}$ & $\begin{array}{c}\mathrm{MeHg} \\
\text { particulate (Q) } \\
\text { (ng/L) }\end{array}$ \\
\hline
\end{tabular}

Site 1, LRS: Lower Reservoir, Shallow (Camp Far West Reservoir 0.3 mile north of dam abutment) Station number 390317121185001

$\begin{array}{rrrcccr}10 / 30 / 2001 & 5: 15 \mathrm{PM} & 10 & - & - & <0.04 & - \\ 02 / 12 / 2002 & 12: 00 \mathrm{PM} & 8 & 0.06 & <0.04 & <0.04 & 0.028 \\ 04 / 22 / 2002 & 3: 20 \mathrm{PM} & 10 & 0.07 & <0.04 & <0.04 & 0.026 \\ 08 / 06 / 2002 & 4: 30 \mathrm{PM} & 10 & 0.12 & <0.04 & <0.04 & <0.044 \\ 04 / 15 / 2003 & 10: 30 \mathrm{AM} & 40 & 0.09 & <0.04 & <0.04 & <0.029\end{array}$

Site 2, LRT: Lower Reservoir, Thalweg (Camp Far West Reservoir in thalweg near dam near Wheatland) Station number 390307121183801

$\begin{array}{lrrrrrr}11 / 01 / 2001 & 8: 30 \mathrm{AM} & 70 & - & - & - & - \\ 02 / 12 / 2002 & 11: 00 \mathrm{AM} & 140 & 0.06 & 0.04 & 0.05 & 0.01 \\ 04 / 22 / 2002 & 3: 00 \mathrm{PM} & 140 & 0.06 & 0.04 & 0.06 & 0.011 \\ 08 / 08 / 2002 & 12: 00 \mathrm{PM} & 45 & \mathrm{E} 0.07 & <0.04 & <0.04 & <0.043 \\ 08 / 08 / 2002 & 1: 30 \mathrm{PM} & 113 & 0.04 & <0.04 & <0.04 & <0.043 \\ 11 / 04 / 2002 & 3: 50 \mathrm{PM} & 10 & 0.09 & <0.04 & <0.04 & 0.097 \\ 11 / 04 / 2002 & 3: 20 \mathrm{PM} & 55 & <0.04 & <0.04 & <0.04 & <0.029 \\ 01 / 29 / 2003 & 2: 30 \mathrm{PM} & 10 & <0.04 & <0.04 & <0.04 & <0.029 \\ 01 / 28 / 2003 & 4: 40 \mathrm{PM} & 140 & 0.06 & 0.04 & 0.05 & <0.029 \\ 04 / 16 / 2003 & 4: 00 \mathrm{PM} & 150 & 0.07 & 0.05 & <0.04 & <0.029 \\ 08 / 05 / 2003 & 12: 30 \mathrm{PM} & 1 & 0.04 & 0.04 & <0.04 & <0.029 \\ 08 / 05 / 2003 & 3: 30 \mathrm{PM} & 73 & <0.04 & <0.04 & - & <0.029 \\ 08 / 05 / 2003 & 1: 00 \mathrm{PM} & 120 & 0.06 & 0.05 & 0.04 & <0.029\end{array}$

Site 3, MRS: Middle Reservoir, Shallow (Camp Far West Reservoir east shoreline 1.6 miles above dam) Station number 390244121171801

$\begin{array}{rrrrrrr}10 / 29 / 2001 & 4: 15 \text { PM } & 6 & - & - & <0.04 & - \\ 02 / 12 / 2002 & 1: 30 \text { PM } & 60 & 0.04 & <0.04 & 0.04 & 0.033 \\ 04 / 22 / 2002 & 1: 50 \text { PM } & 10 & 0.06 & <0.04 & <0.04 & 0.023 \\ 04 / 15 / 2003 & 12: 40 \text { PM } & 32 & 0.07 & 0.04 & 0.06 & <0.029\end{array}$

Site 4, MRT: Middle Reservoir, Thalweg (Camp Far West Reservoir in thalweg 1.5 miles above dam) Station number 390238121173101

$\begin{array}{lrrrrrr}10 / 29 / 2001 & 2: 45 \text { PM } & 50 & - & - & <0.04 & - \\ 02 / 13 / 2002 & 8: 30 \mathrm{AM} & 120 & 0.04 & <0.04 & <0.04 & 0.01 \\ 04 / 22 / 2002 & 12: 20 \mathrm{PM} & 120 & 0.07 & 0.05 & 0.06 & 0.014 \\ 08 / 07 / 2002 & 12: 10 \mathrm{PM} & 10 & 0.06 & <0.04 & <0.04 & <0.047 \\ 08 / 07 / 2002 & 12: 40 \mathrm{PM} & 47 & 0.08 & <0.04 & 0.04 & <0.045 \\ 08 / 08 / 2002 & 2: 50 \mathrm{PM} & 80 & 0.05 & <0.04 & <0.04 & <0.043 \\ 11 / 05 / 2002 & 2: 30 \mathrm{PM} & 10 & 0.05 & <0.04 & <0.04 & 0.54 \\ 11 / 05 / 2002 & 2: 10 \mathrm{PM} & 30 & <0.04 & <0.04 & <0.04 & <0.029 \\ 01 / 29 / 2003 & 2: 00 \mathrm{PM} & 10 & 0.07 & <0.04 & 0.04 & 0.037 \\ 01 / 28 / 2003 & 3: 30 \mathrm{PM} & 120 & 0.06 & 0.05 & \mathrm{E} 0.05 & <0.029 \\ 04 / 17 / 2003 & 10: 30 \mathrm{AM} & 125 & 0.12 & 0.04 & 0.04 & <0.029 \\ 08 / 07 / 2003 & 11: 30 \mathrm{AM} & 1 & \mathrm{E} 0.04 & <0.04 & <0.04 & <0.029 \\ 08 / 07 / 2003 & 11: 50 \mathrm{AM} & 100 & <0.04 & <0.04 & - & <0.029\end{array}$


Table 7. Data for methylmercury in water samples, Camp Far West Reservoir, California._Continued

[The number in parentheses is the data parameter code, a five-digit code used in the U.S. Geological Survey computerized data system. thalweg, former river channel (low elevation path). C45, 0.45-micrometer capsule filter; Q, quartz fiber filter; MeHg, methylmercury; ft, foot; ng/L, nanogram per liter; E, estimated. <, less than; -, not determined]

\begin{tabular}{|c|c|c|c|c|c|c|}
\hline Date & Time & $\begin{array}{c}\text { Depth } \\
\text { (ft) }\end{array}$ & $\begin{array}{c}\text { MeHg } \\
\text { unfiltered } \\
(\mathrm{ng} / \mathrm{L}) \\
(50284)\end{array}$ & $\begin{array}{c}\mathrm{MeHg} \\
\text { filtered (C45) } \\
(\mathrm{ng} / \mathrm{L}) \\
(50285)\end{array}$ & $\begin{array}{c}\text { MeHg } \\
\text { filtered (0) } \\
\text { (ng/L) } \\
(\mathbf{5 0 2 8 5 )}\end{array}$ & $\begin{array}{c}\mathrm{MeHg} \\
\text { particulate (0) } \\
\text { (ng/L) }\end{array}$ \\
\hline
\end{tabular}

Site 5, BRA: Bear River arm (Camp Far West Reservoir Bear River arm near Wheatland) Station number 390202121162201

$\begin{array}{lrrrrrc}10 / 31 / 2001 & 10: 15 \mathrm{AM} & 12 & <0.04 & - & <0.04 & - \\ 02 / 13 / 2002 & 9: 00 \mathrm{AM} & 80 & 0.07 & 0.05 & 0.05 & 0.018 \\ 04 / 22 / 2002 & 10: 40 \mathrm{AM} & 80 & 0.12 & 0.05 & 0.06 & 0.02 \\ 08 / 06 / 2002 & 5: 50 \mathrm{PM} & 10 & <0.04 & <0.04 & <0.04 & <0.046 \\ 08 / 06 / 2002 & 6: 20 \mathrm{PM} & 55 & 0.46 & 0.22 & 0.32 & 0.16 \\ 11 / 05 / 2002 & 4: 10 \mathrm{PM} & 7 & 0.05 & <0.04 & 0.15 & <0.030 \\ 01 / 29 / 2003 & 1: 20 \mathrm{PM} & 10 & 0.06 & 0.05 & 0.06 & <0.029 \\ 01 / 28 / 2003 & 2: 50 \mathrm{PM} & 85 & 0.07 & \mathrm{E} 0.05 & 0.05 & <0.029 \\ 04 / 17 / 2003 & 11: 30 \mathrm{AM} & 90 & 0.08 & 0.06 & 0.06 & <0.029 \\ 08 / 07 / 2003 & 10: 00 \mathrm{AM} & 1 & 0.05 & 0.04 & <0.04 & <0.029 \\ 08 / 06 / 2003 & 3: 00 \mathrm{PM} & 100 & 0.30 & 0.06 & 0.08 & 0.39\end{array}$

Site 6, DFA: Dairy Farm arm (Camp Far West Reservoir Dairy Farm arm near Wheatland)

Station number 390159121171401

$\begin{array}{rrrrrrr}10 / 31 / 2001 & 1: 00 \mathrm{PM} & 4 & 0.04 & - & <0.04 & - \\ 02 / 13 / 2002 & 1: 00 \mathrm{PM} & 20 & 0.06 & <0.04 & <0.04 & 0.018 \\ 04 / 23 / 2002 & 12: 10 \mathrm{PM} & 20 & 0.06 & <0.04 & 0.04 & 0.014 \\ 08 / 07 / 2002 & 6: 50 \mathrm{PM} & 57 & 0.19 & 0.08 & 0.06 & 0.08 \\ 01 / 30 / 2003 & 3: 30 \mathrm{PM} & 55 & 0.06 & 0.05 & 0.05 & <0.029 \\ 04 / 17 / 2003 & 2: 30 \mathrm{PM} & 55 & 0.15 & 0.07 & 0.07 & 0.046 \\ 08 / 07 / 2003 & 4: 00 \mathrm{PM} & 1 & <0.04 & <0.04 & & <0.029\end{array}$

Site 7, RCA: Rock Creek arm (Camp Far West Reservoir Rock Creek arm)

Station number 390331121174101

$\begin{array}{lrrrrrr}08 / 07 / 2002 & 03: 40 \mathrm{PM} & 10 & 0.07 & 0.04 & 0.04 & <0.045 \\ 04 / 17 / 2003 & 01: 20 \mathrm{PM} & 80 & 0.10 & 0.06 & <0.04 & 0.051 \\ 08 / 07 / 2003 & 01: 00 \mathrm{PM} & 1 & 0.06 & 0.08 & - & <0.029 \\ 08 / 07 / 2003 & 01: 30 \mathrm{PM} & 40 & <0.04 & <0.04 & - & <0.029\end{array}$

Site 8, DFP: Dairy Farm Mine Pit Lake (Dairy Farm Mine pit lake near Wheatland)

Station number 390148121171701

$\begin{array}{lrrrrrr}10 / 31 / 2001 & 2: 15 \text { PM } & 1 & - & - & <0.04 & - \\ 02 / 13 / 2002 & 3: 10 \text { PM } & 10 & 0.06 & <0.04 & <0.04 & 0.015 \\ 02 / 13 / 2002 & 3: 30 \text { PM } & 35 & <0.04 & <0.04 & <0.04 & 0.013 \\ 04 / 24 / 2002 & 11: 10 \mathrm{AM} & 30 & 0.07 & 0.05 & 0.05 & 0.026 \\ 08 / 07 / 2002 & 5: 00 \mathrm{PM} & 0.5 & <0.04 & <0.04 & <0.04 & <0.046 \\ 11 / 05 / 2002 & 2: 50 \mathrm{PM} & 1 & <0.04 & <0.04 & <0.04 & <0.029 \\ 01 / 30 / 2003 & 12: 30 \mathrm{PM} & 10 & <0.04 & <0.04 & <0.04 & 0.049 \\ 01 / 30 / 2003 & 1: 20 \mathrm{PM} & 38 & 0.08 & <0.04 & <0.04 & <0.029 \\ 04 / 17 / 2003 & 4: 00 \mathrm{PM} & 40 & <0.04 & <0.04 & 0.04 & -0.029 \\ 08 / 07 / 2003 & 4: 30 \mathrm{PM} & 1 & <0.04 & <0.04 & - & \end{array}$

Site 9, DFI: Dairy Farm Mine Impoundments (Camp Far West Reservoir impoundment Dairy Farm Mine arm) Station number 390152121171001

$\begin{array}{rcccccr}10 / 31 / 2001 & 2: 40 \mathrm{PM} & 0.5 & - & - & - & - \\ 02 / 13 / 2002 & 2: 20 \mathrm{PM} & 52 & 0.04 & - & 0.06 & 0.018 \\ 04 / 23 / 2002 & 1: 10 \mathrm{PM} & 20 & 0.06 & <0.04 & <0.04 & 0.011 \\ 11 / 05 / 2002 & 2: 00 \mathrm{PM} & 0.5 & <0.04 & <0.04 & <0.04 & <0.029\end{array}$




\section{Suspended Solids and Major Elements}

The suspended-solids concentration (SSC) in water samples from Camp Far West Reservoir ranged from less than the MDL of $1 \mathrm{mg} / \mathrm{L}$ to a maximum of $30 \mathrm{mg} / \mathrm{L}$ during the study period (tables 2 and $\underline{8}$ ). The SSC values were highest during the fall of 2001 and 2002, and the summer of 2002 (fig. 8A). Concentrations of particulate iron, computed as the difference between unfiltered and filtered concentrations (tables G3, G4, respectively), vary seasonally (fig. 8B) in a pattern partly similar to that for SSC, with elevated values in the fall of 2001 and 2002; however, the situation was different during summer 2002, when SSC concentrations were relatively high but particulate Fe concentrations were relatively low in most samples.

Concentrations of calcium in filtered water (table G4, fig. 8C) were highest in the acidic water samples from the Dairy Farm Mine pit lake and impoundments (sites 8 and 9). At other stations in the reservoir, calcium concentrations were higher in the fall than in the other seasons by a factor of about two. A similar seasonal pattern is evident for concentrations of other major cations, such as magnesium, sodium, and potassium (table G4). Sulfate ( $\left.\mathrm{SO}_{4}\right)$ concentrations (table 3 , fig. $8 D$ ) show a pattern similar to that of calcium, with highest values associated with the acid mine waters, and fall concentrations about twice those of the other seasons at other stations.

Correlation plots of major cations (such as sodium and calcium) and anions (chloride and sulfate) in filtered water (figs. 9A-9D) indicate that seasonal differences appear to be more significant than spatial differences within the reservoir. The data also indicate that elevated concentrations of major constituents in the fall are similar to the composition of input water from the Bear River during this period. Averageconcentration data for eight fall-season samples collected at approximately monthly intervals during 2001-03 from the Bear River below Wolf Creek near Lucas Hill, USGS station 390107121102101 are shown by a black circle on figures $9 A-$ $\underline{9 D}$ for comparison (error bars indicate standard deviations for eight samples). Sodium ( $\mathrm{Na}$ ) and chloride (Cl) concentrations in water samples from Camp Far West Reservoir correlate closely; data for all sites except sites 8 and 9 are close to the 1:1 molar ratio line (fig. 9A). The average of fall data for $\mathrm{Na}$ and $\mathrm{Cl}$ from the Bear River below Wolf Creek plots within the range of the fall data for Camp Far West Reservoir. The correlation between calcium and chloride (fig. 9B) also is positive but less consistent than that between $\mathrm{Na}$ and $\mathrm{Cl}$; molar concentrations of $\mathrm{Ca}$ are less than the corresponding molar concentrations of $\mathrm{Cl}$ for all samples except one from the Dairy
Farm Mine area. The correlation between $\mathrm{Cl}$ and $\mathrm{SO}_{4}$ (fig. 9C) indicates that $\mathrm{Cl}$ is more abundant than $\mathrm{SO}_{4}$ on a molar basis in all water samples from CFWR except those most acutely affected by acid mine drainage associated with the Dairy Farm Mine. The correlation between $\mathrm{Ca}$ and $\mathrm{SO}_{4}(\underline{\mathrm{fig} .9 \mathrm{D}}$ ) is similar to those of $\mathrm{Ca}$ and $\mathrm{Cl}$ (fig. 9B) and $\mathrm{Cl}$ and $\mathrm{SO}_{4}$ (fig. 9C). The diagonal line on figure $9 \mathrm{D}$ labeled $\mathrm{Ca}: \mathrm{SO}_{4}=1: 1$ represents an equimolar increase of $\mathrm{Ca}$ and $\mathrm{SO}_{4}$, a trend that would result from the dissolution of gypsum $\left(\mathrm{CaSO}_{4} \cdot 2 \mathrm{H}_{2} \mathrm{O}\right)$, a common mineral in marine sedimentary rocks. The diagonal line labeled $\mathrm{Ca}: \mathrm{SO}_{4}=4: 1$ approximates the trend in the data for most samples from CFWR, indicating that gypsum dissolution is not a likely explanation for the coupled increase in $\mathrm{Ca}$ and $\mathrm{SO}_{4}$ concentrations between summer and fall. As in figure $9 \mathrm{~A}$, the data in figures $9 B-9 D$ show that the composition of water entering Camp Far West Reservoir from the Bear River is consistent with the seasonal shift to larger concentrations of major elements in the fall. Because of the extreme drawdown of CFWR during fall, the residence time of solutes is much lower and it is reasonable to expect that a shift in the composition of the input water could cause a fairly rapid shift in the composition of CFWR.

\section{Stable Isotopes of Water and Aqueous Sulfate}

The relation between stable isotopes of oxygen and hydrogen in water from Camp Far West Reservoir is most easily understood in the context of similar data from sampling stations in the Bear River. On a plot of isotopic data from water samples collected throughout the Bear River watershed (fig. 10A), two important trends with distinct slopes are evident. Most of the data plot parallel to the Global Meteoric Water Line (GWML), which defines a world-wide trend for precipitation by the relation $\delta \mathrm{D}=\delta^{18} \mathrm{O}+10$ (Craig and others, 1963). Isotope data for samples from stations that are dominated by flow from higher elevations in the watershed, such as Bear River below Steephollow Creek near Chicago Park (USGS station 391023120541301) (station a, fig. 1), and Bear River below Rollins Dam near Colfax (USGS station 11422500) (station c, fig. 1), have the smallest values of $\delta^{18} \mathrm{O}$ and $\delta \mathrm{D}$, consistent with precipitation forming at lower temperatures and falling at higher elevations (Craig and others, 1963). Samples from Greenhorn Creek at You Bet Road near Nevada City (USGS station 391116120562501) (station a, fig. 1) plot along the GMWL but at larger values of $\delta^{18} \mathrm{O}$ and $\delta \mathrm{D}$, consistent with precipitation falling at higher temperatures and lower elevations (Ingraham, 1998). 
Table 8. Statistical data for field measurements and suspended solids concentrations, Camp Far West Reservoir, California.

[Suspended silt plus clay is the product of suspended solids concentrations and percent suspended solids sieved. ${ }^{\circ} \mathrm{C}$, degree Celsius; mg/L, milligram per liter; $\mu \mathrm{S} / \mathrm{cm}$, microsiemens per centimeter; n, number of samples]

\begin{tabular}{|c|c|c|c|c|c|c|}
\hline & $\begin{array}{c}\text { Temperature } \\
\left({ }^{\circ} \mathrm{C}\right)\end{array}$ & $\begin{array}{l}\text { Dissolved } \\
\text { oxygen } \\
\text { (mg/L) }\end{array}$ & $\mathrm{pH}$ & $\begin{array}{c}\text { Specific } \\
\text { conductance } \\
(\mu \mathrm{S} / \mathrm{cm})\end{array}$ & $\begin{array}{l}\text { Total } \\
\text { suspended } \\
\text { solids } \\
\text { (mg/L) }\end{array}$ & $\begin{array}{l}\text { Suspended silt } \\
\text { plus clay } \\
\text { (mg/L) }\end{array}$ \\
\hline \multicolumn{7}{|l|}{ All samples } \\
\hline Mean & 14.6 & 8.1 & 7.0 & 164 & 9.8 & 8.4 \\
\hline Standard error of mean & 0.78 & 0.44 & 0.13 & 32 & 1.0 & 0.9 \\
\hline Standard deviation & 6.5 & 3.7 & 1.1 & 267 & 7.9 & 7.1 \\
\hline Minimum & 7.0 & 0.0 & 3.0 & 69 & 0 & 0 \\
\hline 25 th percentile & 9.6 & 6.6 & 6.8 & 84 & 5 & 3 \\
\hline Median & 11.4 & 8.7 & 7.3 & 90 & 7.5 & 6 \\
\hline 75th percentile & 17.6 & 10.3 & 7.7 & 127 & 11 & 10 \\
\hline Maximum & 27.5 & 14.6 & 8.4 & 1,660 & 30 & 30 \\
\hline $\mathrm{n}$ & 69 & 69 & 71 & 71 & 68 & 68 \\
\hline \multicolumn{7}{|c|}{ All reservoir samples (excluding Dairy Farm Mine Pit Lake and Impoundments) } \\
\hline Mean & 14.8 & 8.1 & 7.3 & 98 & 10.4 & 8.9 \\
\hline Standard error of mean & 0.86 & 0.5 & 0.06 & 3.4 & 1.1 & 1.0 \\
\hline Standard deviation & 6.5 & 3.8 & 0.47 & 26 & 8.1 & 7.2 \\
\hline Minimum & 7.0 & 0.0 & 6.4 & 69 & 0 & 0 \\
\hline 25 th percentile & 9.8 & 6.1 & 6.9 & 81 & 5 & 4 \\
\hline Median & 13.0 & 8.5 & 7.4 & 88 & 9 & 7 \\
\hline 75th percentile & 17.8 & 10.6 & 7.7 & 109 & 13 & 11 \\
\hline Maximum & 27.5 & 14.6 & 8.4 & 155 & 30 & 30 \\
\hline $\mathrm{n}$ & 57 & 57 & 57 & 57 & 57 & 57 \\
\hline \multicolumn{7}{|c|}{ Epilimnion (excluding Dairy Farm Mine Pit Lake and Impoundments) } \\
\hline Mean & 15 & 9.6 & 7.5 & 100 & 10 & 9 \\
\hline Standard error of mean & 1.1 & 0.36 & 0.05 & 4.1 & 1.3 & 1.2 \\
\hline Standard deviation & 7.1 & 2.4 & 0.36 & 27 & 8.8 & 7.8 \\
\hline Minimum & 7.0 & 4.2 & 6.7 & 69 & 0 & 0 \\
\hline 25th percentile & 9.3 & 7.9 & 7.3 & 83 & 3.5 & 3 \\
\hline Median & 14.0 & 9.6 & 7.5 & 88 & 8 & 7 \\
\hline 75th percentile & 17.8 & 11.7 & 7.8 & 121 & 14.5 & 10.5 \\
\hline Maximum & 27.5 & 14.6 & 8.4 & 155 & 30 & 30 \\
\hline $\mathrm{n}$ & 45 & 45 & 45 & 45 & 45 & 45 \\
\hline \multicolumn{7}{|c|}{ Hypolimnion and Metalimnion } \\
\hline Mean & 14.1 & 2.3 & 6.7 & 88 & 10.7 & 9.6 \\
\hline Standard error of mean & 1.2 & 0.58 & 0.06 & 4.2 & 1.5 & 1.4 \\
\hline Standard deviation & 4.1 & 2.0 & 0.2 & 15 & 5.2 & 4.8 \\
\hline Minimum & 10.5 & 0.0 & 6.4 & 72 & 5 & 4 \\
\hline 25 th percentile & 11.0 & 0.3 & 6.5 & 77 & 6.3 & 6 \\
\hline Median & 11.8 & 1.8 & 6.7 & 87 & 10 & 9 \\
\hline 75th percentile & 18.9 & 4.3 & 6.9 & 96 & 12 & 11 \\
\hline Maximum & 21.5 & 5.7 & 7.0 & 124 & 22 & 20 \\
\hline $\mathrm{n}$ & 12 & 12 & 12 & 12 & 12 & 12 \\
\hline
\end{tabular}



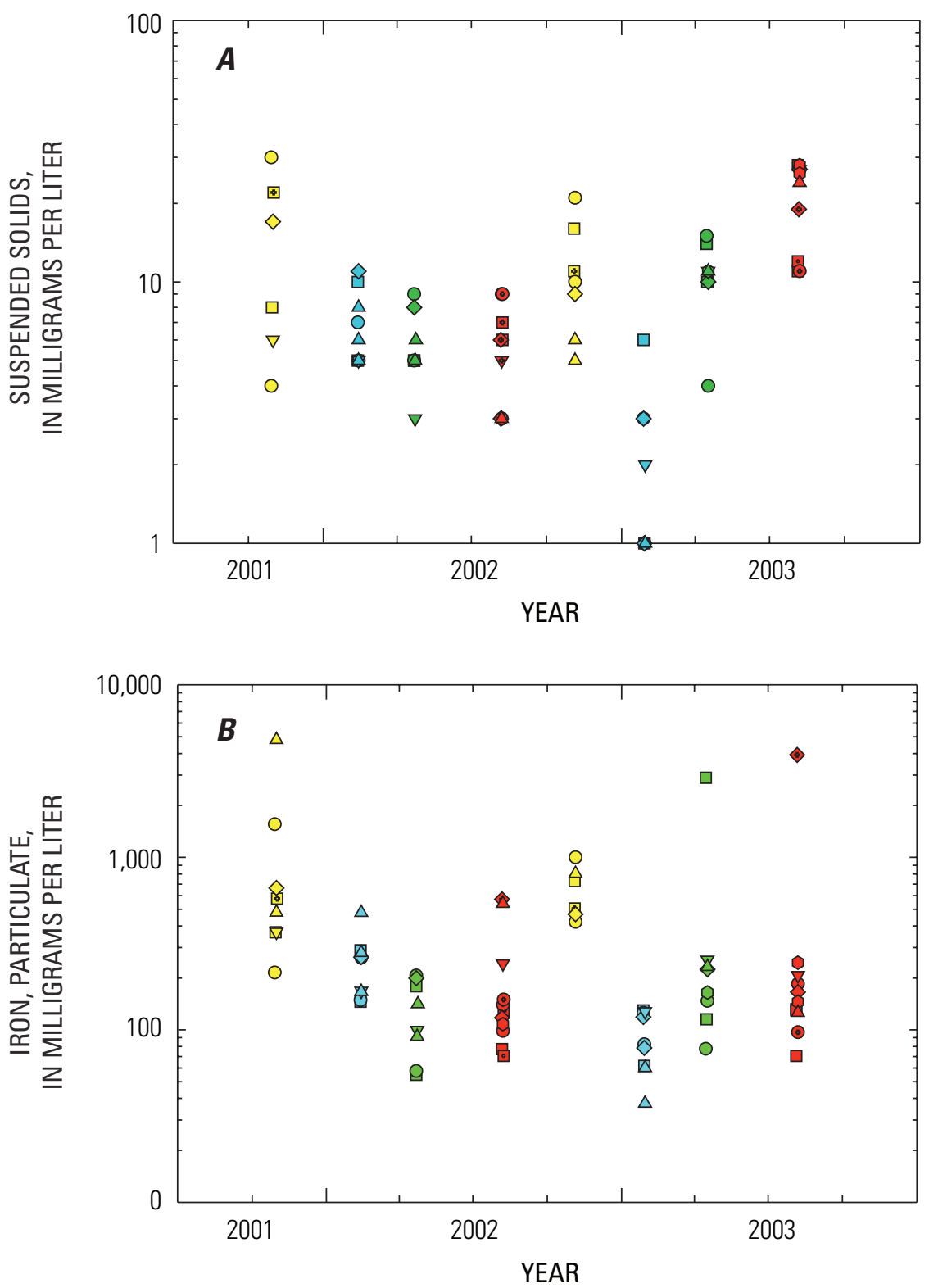

EXPLANATION

\begin{tabular}{|c|c|c|c|c|c|}
\hline & Site Number & Fall & Winter & Spring $\mathrm{S}$ & Summer \\
\hline Lower reservoir & 1,2 & $\square$ & $\square$ & $\square$ & $\square$ \\
\hline Mid-reservoir & 3,4 & o & 0 & o & ○ \\
\hline Bear River arm & 5 & $\diamond$ & $\diamond$ & $\diamond$ & $\diamond$ \\
\hline Dairy Farm arm & 6 & $\nabla$ & $\nabla$ & $\nabla$ & $\nabla$ \\
\hline Rock Creek arm & 7 & 0 & 0 & 0 & 0 \\
\hline \multirow{2}{*}{$\begin{array}{l}\text { Dairy Farm Mine } \\
\text { pit lake and } \\
\text { impoundments }\end{array}$} & 8,9 & $\Delta$ & $\Delta$ & $\Delta$ & $\Delta$ \\
\hline & $\begin{array}{l}\square \circ \diamond \nabla \\
\square \odot\end{array}$ & $\begin{array}{l}\text { Solid s } \\
\text { Dot inc }\end{array}$ & $\begin{array}{l}\text { nbol indicat } \\
\text { ates metali }\end{array}$ & $\begin{array}{l}\text { s epilimnion } \\
\text { mnion }\end{array}$ & \\
\hline
\end{tabular}

Figure 8. Showing concentrations of water-quality constituents for sampling stations in Camp Far West Reservoir, California, 2001-03: (A) Suspended solids, (B) Particulate iron, $(C)$ Calcium in filtered water, $(D)$ Sulfate in filtered water. $\ln (B)$, particulate iron computed as the difference between the concentrations of iron in unfiltered and filtered water. 

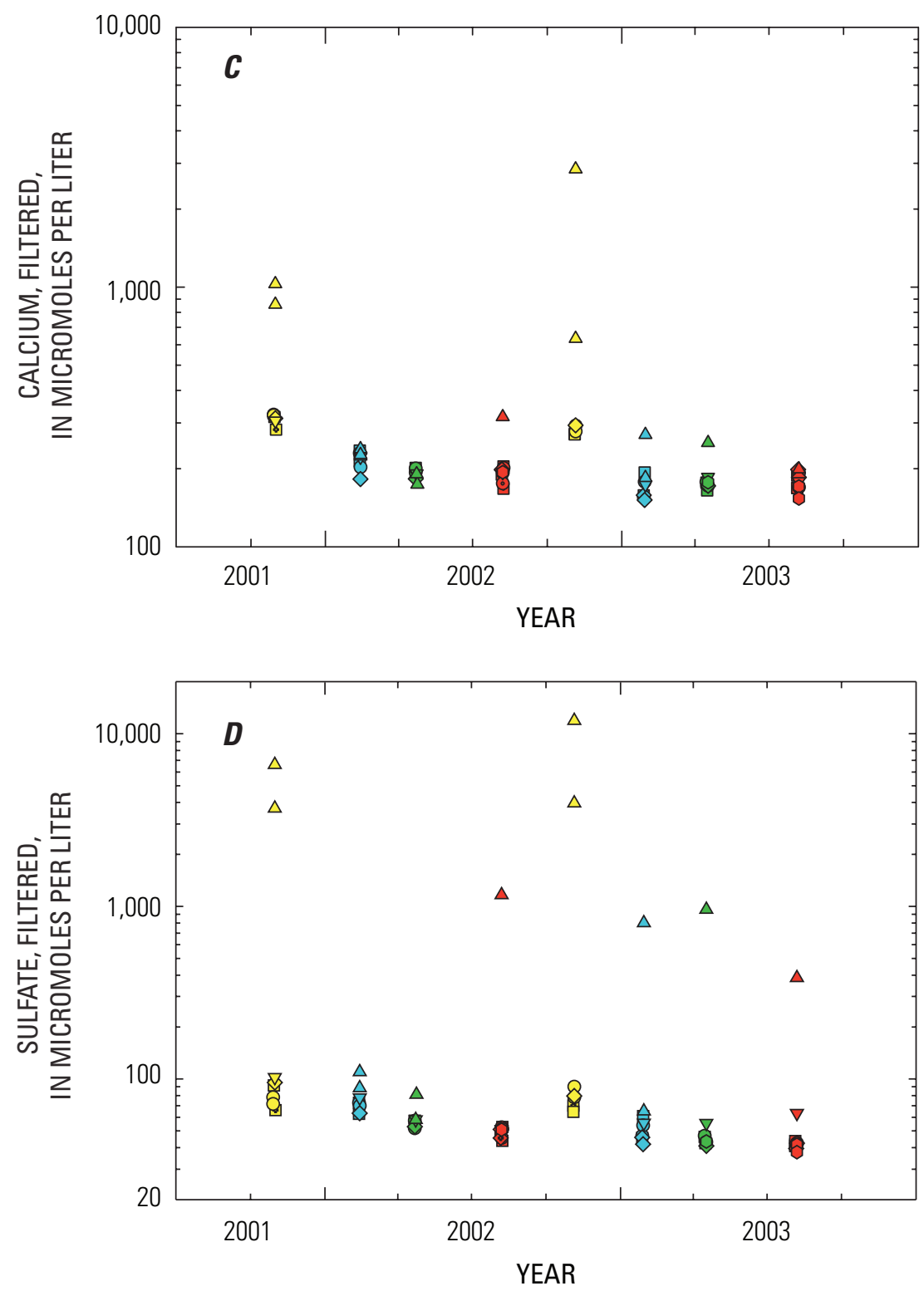

\section{EXPLANATION}

Site Number Fall Winter Spring Summer

$\begin{array}{lcccc}\text { Lower reservoir } & 1,2 & \square & \square & \square \\ \text { Mid-reservoir } & 3,4 & 0 & 0 & 0 \\ \text { Bear River arm } & 5 & \diamond & \diamond & \diamond \\ \text { Dairy Farm arm } & 6 & \nabla & \nabla & \nabla \\ \text { Rock Creek arm } & 7 & 0 & \diamond & \diamond \\ \begin{array}{l}\text { Dairy Farm Mine } \\ \text { pit lake and }\end{array} & 8,9 & \Delta & \Delta & \Delta \\ \text { impoundments } & \square \odot \diamond \nabla & \text { Solid symbol indicates epilimnion } \\ & \square \odot & \text { Dot indicates metalimnion } \\ & \square \odot \diamond \nabla & \text { Cross indicates hypolimnion }\end{array}$

Figure 8. Continued. 

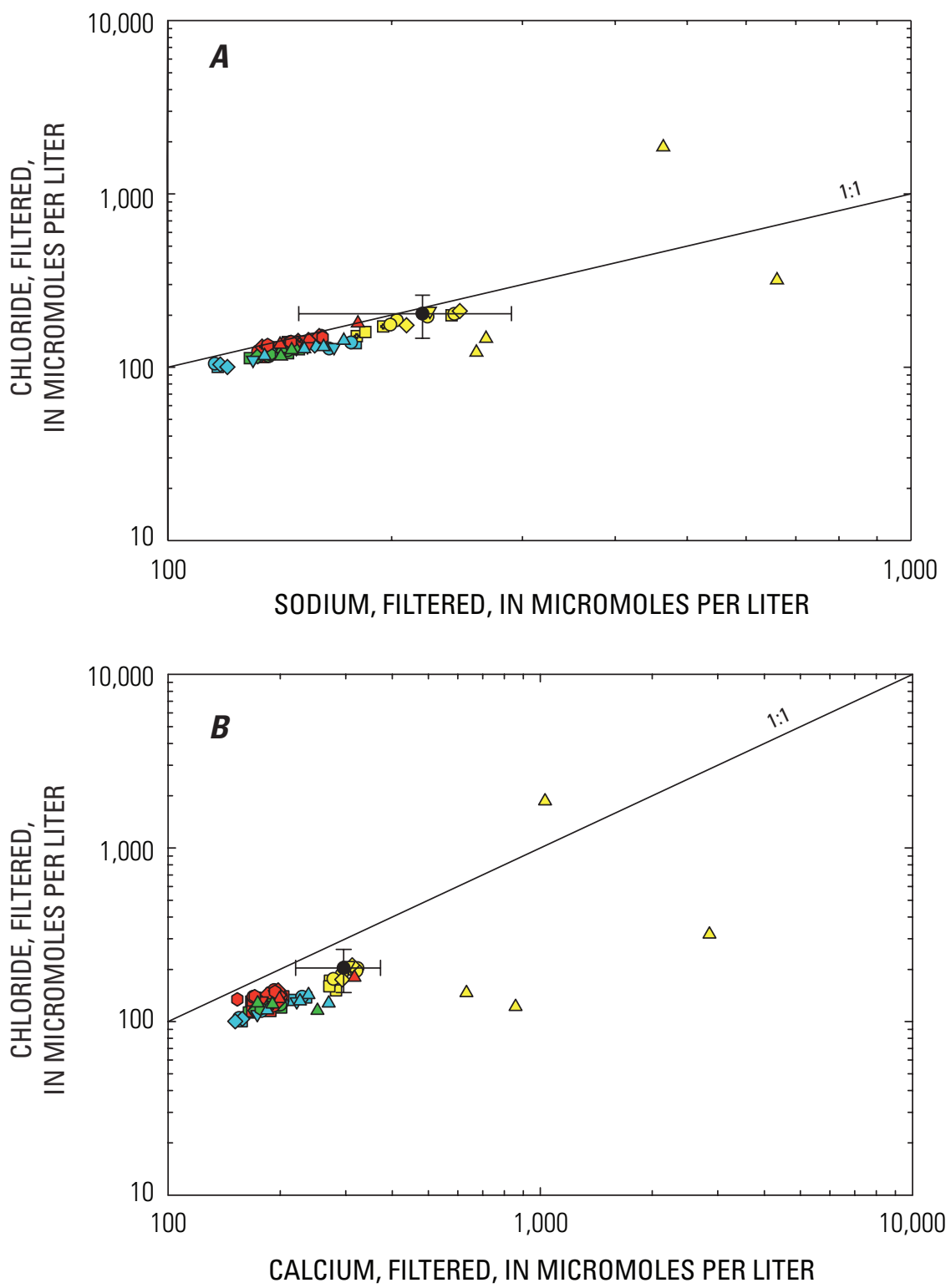

EXPLANATION

\begin{tabular}{|c|c|c|c|c|c|}
\hline & Site Number & Fall & Winter & Spring $S$ & Summer \\
\hline Lower reservoir & 1,2 & $\square$ & $\square$ & $\square$ & $\square$ \\
\hline Mid-reservoir & 3,4 & ० & o & ○ & 0 \\
\hline Bear River arm & 5 & $\diamond$ & $\diamond$ & $\diamond$ & $\diamond$ \\
\hline Dairy Farm arm & 6 & $\nabla$ & $\nabla$ & $\nabla$ & $\nabla$ \\
\hline Rock Creek arm & 7 & 0 & 0 & 0 & ○ \\
\hline $\begin{array}{l}\text { Dairy Farm Mine } \\
\text { pit lake and }\end{array}$ & 8,9 & $\Delta$ & $\Delta$ & $\Delta$ & $\Delta$ \\
\hline impoundments & $\begin{array}{l}\square \circ \diamond \nabla \\
\square \odot\end{array}$ & $\begin{array}{l}\text { Solid s } \\
\text { Dot ind }\end{array}$ & $\begin{array}{l}\text { ol indicat } \\
\text { tes metali }\end{array}$ & $\begin{array}{l}\text { es epilimnion } \\
\text { mnion }\end{array}$ & \\
\hline
\end{tabular}

Figure 9. Relations among major elements in filtered water in Camp Far West Reservoir, California, 2001-03: (A) Sodium and chloride, $(B)$ Calcium and chloride, $(C)$ Sulfate and chloride, $(D)$ Calcium and sulfate. Filled, black circle with error bars represents average concentrations and standard deviations for eight fall-season samples collected at approximately monthly intervals from the Bear River below Wolf Creek near Lucas Hill (USGS station 390107121102101 ) (station e, fig. 1). 

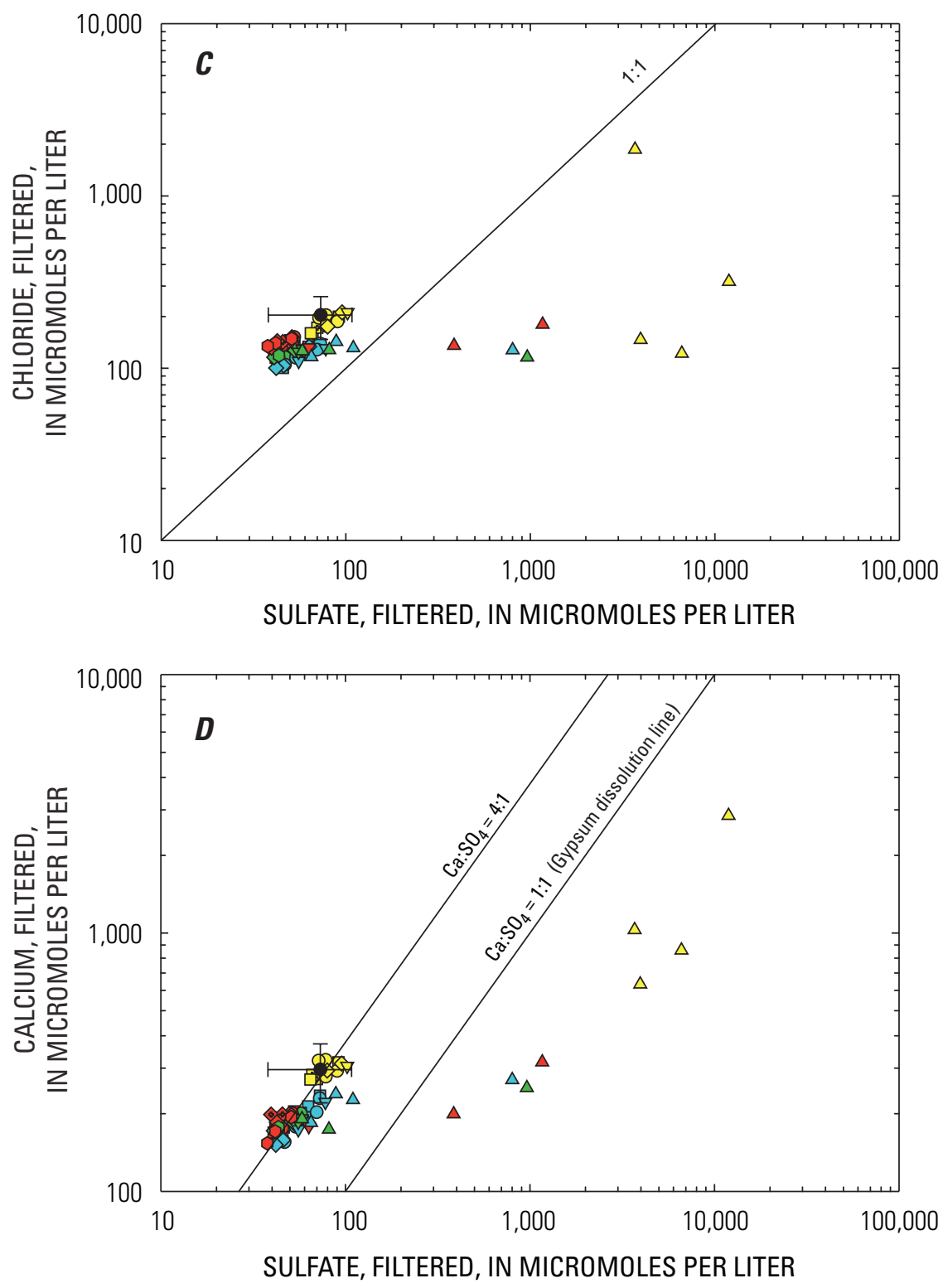

EXPLANATION

\begin{tabular}{|c|c|c|c|c|c|}
\hline Lower reservoir & $\begin{array}{c}\text { Site Number } \\
1,2\end{array}$ & $\begin{array}{c}\text { Fall } \\
\square\end{array}$ & $\begin{array}{c}\text { Winter } \\
\square\end{array}$ & Spring $\subseteq$ & Summer \\
\hline Mid-reservoir & 3,4 & o & o & ○ & ○ \\
\hline Bear River arm & 5 & $\diamond$ & $\diamond$ & $\diamond$ & $\diamond$ \\
\hline Dairy Farm arm & 6 & $\nabla$ & $\nabla$ & $\nabla$ & $\nabla$ \\
\hline Rock Creek arm & 7 & 0 & 0 & 0 & o \\
\hline $\begin{array}{l}\text { Dairy Farm Mine } \\
\text { pit lake and }\end{array}$ & 8,9 & $\triangle$ & $\Delta$ & $\Delta$ & $\Delta$ \\
\hline unaments & $\begin{array}{l}\square \circ \diamond \nabla \\
\square \odot\end{array}$ & $\begin{array}{l}\text { Solid s } \\
\text { Dot ind }\end{array}$ & $\begin{array}{l}\text { bol indic } \\
\text { tes met }\end{array}$ & $\begin{array}{l}\text { s epilimnior } \\
\text { nnion }\end{array}$ & \\
\hline
\end{tabular}

Figure 9. Continued. 


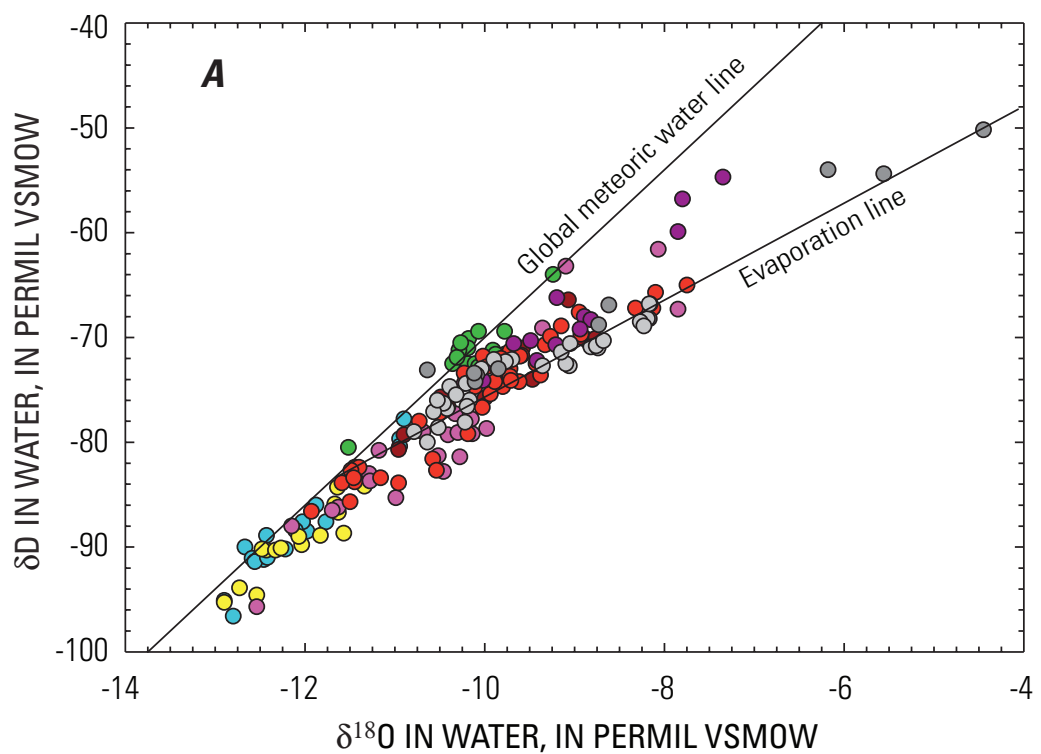

EXPLANATION

- Bear River below Steephollow Creek

- Greenhorn Creek at You Bet Road

- Bear River below Rollins Dam

- Bear River Canal

- Bear River below Wolf Creek

- Bear River below Camp Far West

- Bear River near Berry Road

- Bear River near Wheatland

- Camp Far West Reservoir

- Dairy Farm Mine Pit Lake and Impoundments

Figure 10. Relation between oxygen and hydrogen isotopes in unfiltered water: $(A)$ Bear River stations, including Camp Far West Reservoir, 2001-03, (B) Camp Far West Reservoir stations, 19992003. Global Meteoric Water Line from Craig and others (1963). $\delta D$, delta-deuterium; $\delta^{18} 0$, delta-18-oxygen; VSMOW, Vienna Standard Mean Ocean Water. 


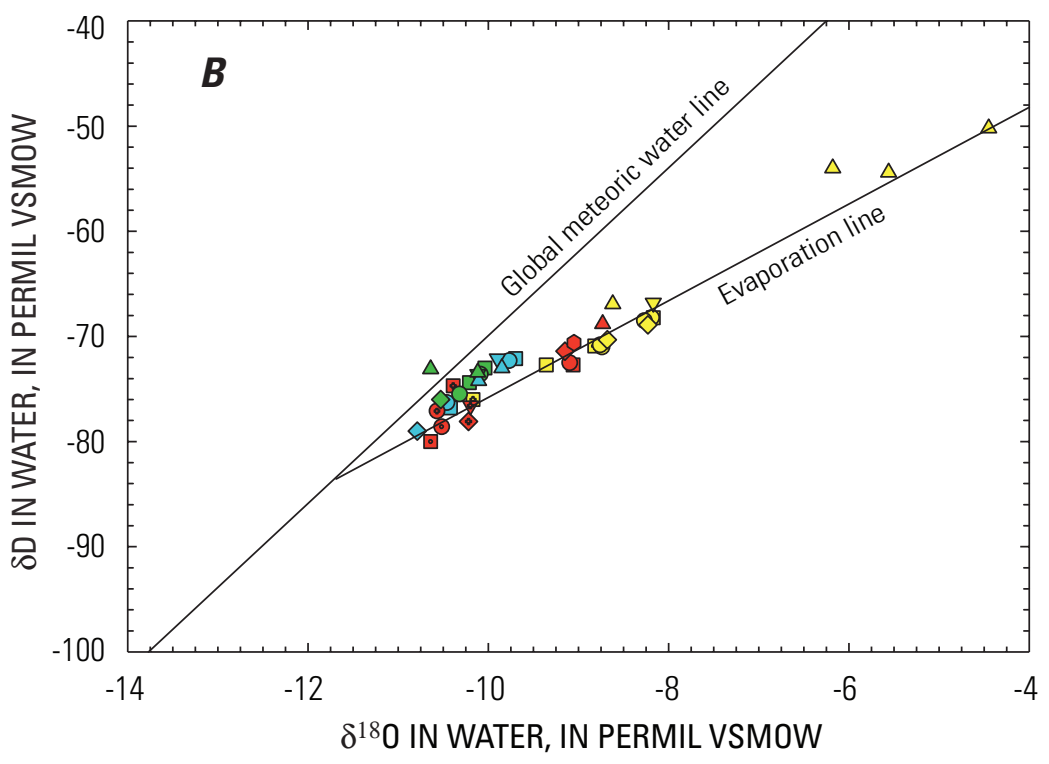

EXPLANATION

\begin{tabular}{|c|c|c|c|c|c|}
\hline Lower reservoir & $\begin{array}{c}\text { Site Number } \\
1,2\end{array}$ & Fall & $\begin{array}{c}\text { Winter } \\
\square\end{array}$ & Spring & Summer \\
\hline Mid-reservoir & 3,4 & 0 & o & o & ○ \\
\hline Bear River arm & 5 & $\diamond$ & $\diamond$ & $\diamond$ & $\diamond$ \\
\hline Dairy Farm arm & 6 & $\nabla$ & $\nabla$ & $\nabla$ & $\nabla$ \\
\hline Rock Creek arm & 7 & 0 & 0 & 0 & 0 \\
\hline Dairy Farm Mine & 8,9 & $\Delta$ & $\Delta$ & $\Delta$ & $\Delta$ \\
\hline Impoundments & $\begin{array}{l}\square \circ \diamond \nabla \\
\square \odot\end{array}$ & $\begin{array}{l}\text { Solid s } \\
\text { Dot inc }\end{array}$ & nbol indic & $\begin{array}{l}\text { es epilimn } \\
\text { mnion }\end{array}$ & \\
\hline
\end{tabular}

Figure 10. Continued. 
Stable isotope data for water samples from CFWR and some of the stations in the lower part of the watershed, such as the Bear River near Wheatland (USGS station 11424000) (station g, fig. 1) follow a trend line with a shallower slope of about 4, consistent with evaporation (fig. 10A). Looking at only the isotopic data from CFWR with seasons colorcoded (fig. 10B), the evaporative trend is most apparent for summer and fall samples from the epilimnion, whereas winter and spring samples plot closer to the GMWL. The samples showing evaporation at the Bear River near Wheatland and other downstream stations (figs. 1, 10A) probably reflect evaporation that took place within CFWR. A time-series plot of $\delta^{18} \mathrm{O}$ for Camp Far West Reservoir water samples (ig. 11A) shows that an evaporative shift to values about 2 permil higher in the summer and fall is limited to epilimnion samples.

There is a significant seasonal trend in the sulfur isotopes of dissolved sulfate in CFWR - decreasing values of $\delta^{34} \mathrm{~S}$ from fall to winter to spring to summer, followed by a dramatic shift to higher values again in the fall (fig. 11B). Oxygen isotope values in aqueous sulfate $\left(\delta^{18} \mathrm{O}_{\mathrm{sO} 4}\right)$ show a less systematic seasonal variation than the sulfur isotope values (figs. $11 C$, $\underline{12 A}$ ). Excluding the data from sites 8 and 9, there appears to be a trend toward smaller values of $\delta^{18} \mathrm{O}_{\mathrm{SO} 4}$ (about 1 permil less, on average) in summer 2002 compared with fall 2001.

The relations between $\delta^{34} \mathrm{~S}_{\mathrm{SO} 4}$ values and aqueous $\mathrm{SO}_{4}$ and Ca concentrations (igs. 12B, 12C) are useful for determining whether seasonal shifts in $\delta^{34} S$ may be caused by variation in geologic (or possible anthropogenic) sources. Sulfate concentration tends to decrease from fall to winter to spring, stay low into summer, and increase again each fall. The fall increase in $\mathrm{SO}_{4}$ concentration may be caused to some extent by evaporative concentration, as discussed above in the context of oxygen and hydrogen isotopes in water. The samples with by far the highest sulfate concentration are those from the Dairy Farm Mine pit lake and impoundments (sites 8 and 9). It is clear from the hydrologic setting that oxidizing sulfide minerals in the Dairy Farm Mine area contribute dissolved sulfate to CFWR. Each year, the pit lake becomes isolated from CFWR during summer and fall and turns severely acidic, with low values of $\mathrm{pH}$ (table 1), and elevated concentrations of sulfate (table 3) and trace metals (tables G3, $\mathrm{G} 4)$. The $\delta^{34} \mathrm{~S}_{\mathrm{SO} 4}$ values in the pit lake and impoundments range from 0.1 to 1.3 permil (table 4 ), with a median value of 0.5 permil. Values of $\delta^{34} S$ in the fall for water samples from CFWR stations (excluding the Dairy Farm Mine pit lake and impoundments, sites 8 and 9) range from 2.0 to 3.2 permil, distinctly higher than the other seasons (figs. 11-12). It appears that this variation is best explained by the input to CFWR from the Bear River, which also has relatively high values of $\delta^{34} \mathrm{~S}_{\mathrm{SO} 4}$ and relatively high concentrations of $\mathrm{Ca}$ and $\mathrm{SO}_{4}$ in the fall.

\section{Nutrients and Organic Carbon}

Nutrients are a crucial water-quality component in this study because of their role in affecting primary production (phytoplankton), the base of the food web in the reservoir (Stewart and others, 2008). As described earlier for major cations and anions, seasonal differences for several nutrient constituents appear to be more significant than spatial differences among sampling stations in the reservoir.

A time-series plot of total phosphorus $(\mathrm{P})$ in unfiltered water (fig. 13A) shows a generally declining trend at several sites from fall to winter and spring to summer. An exception to the trend is two hypolimnion samples from summer 2002 and 2003 from the BRA station, which had anomalously high values of total $\mathrm{P}$ in contrast to samples from the other stations collected during the same sampling events, consistent with observations by Kuwabara and others (2003). No clear seasonal trends are apparent for filtered total phosphorus (fig. 13B), for which concentrations generally are much lower than unfiltered total phosphorus (ig. 13A). Particulate total P concentrations were calculated as the difference between unfiltered and filtered samples (table 5). (Values equal to one-half the MDL were substituted for filtered samples with non-detected concentrations.) A time-series plot of particulate total P (fig. 13C) shows a pattern very similar to that for total $\mathrm{P}$ in unfiltered water.

A conceptual model has been proposed in which microbial activity, which likely takes place mainly in shallow sediments and the lower, anoxic part of the water column within the reservoir thalweg, includes iron reduction that causes the release of $\mathrm{P}$ associated with hydrous iron oxide particles. For samples taken in this study, concentrations of orthophosphate in filtered water were consistently below the MDL of $0.02 \mathrm{mg} / \mathrm{L}$ (table 5), which is equivalent to 0.21 micromoles per liter; however, Kuwabara and others (2003) used a more sensitive analytical method for samples collected during two of the eight quarterly sampling events at three of the CFWR stations. Measured orthophosphate concentrations in filtered samples taken at depth in CFWR were greater than those in shallower samples (Kuwabara and others (2003). Thus, it is hypothesized that the release of orthophosphate to the water column during the summer and fall may be an important step in triggering a phytoplankton bloom that peaks in the fall and winter. (See data for chlorophyll-a and pheophytin in appendix G, table G5; more extensive data for chlorophyll-a and pheophytin were collected by Stewart and others, 2008.) 

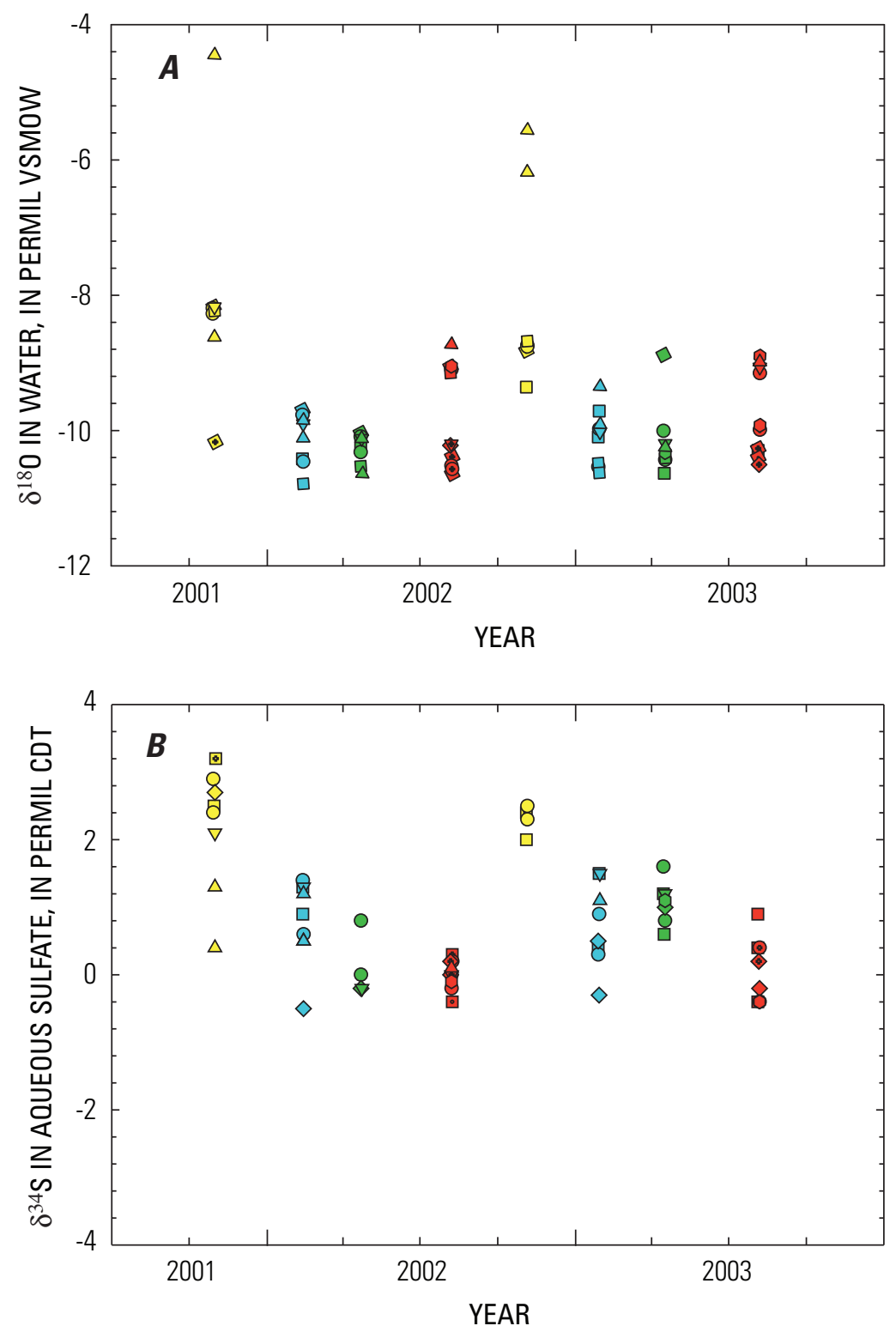

\section{EXPLANATION}

Site Number Fall Winter Spring Summer

$\begin{array}{lccccc}\text { Lower reservoir } & 1,2 & \square & \square & \square & \square \\ \text { Mid-reservoir } & 3,4 & 0 & 0 & 0 & 0 \\ \text { Bear River arm } & 5 & \diamond & \diamond & \diamond & \diamond \\ \text { Dairy Farm arm } & 6 & \nabla & \nabla & \nabla & \nabla \\ \text { Rock Creek arm } & 7 & \diamond & 0 & \bullet & \bullet \\ \begin{array}{l}\text { Dairy Farm Mine } \\ \text { pit lake and }\end{array} & 8,9 & \Delta & \Delta & \Delta & \Delta \\ \text { impoundments } & \square \circ \diamond \nabla & \text { Solid symbol indicates epilimnion } \\ & \square \odot & \text { Dot indicates metalimnion } \\ & \square \odot \diamond \nabla & \text { Cross indicates hypolimnion }\end{array}$

Figure 11. Stable isotope data for Camp Far West Reservoir, California, 2001-03: $(A)$ Oxygen isotopes in water, $(B)$ Sulfur isotopes in aqueous sulfate. $\delta^{18} 0$, delta-18-oxygen; $\delta^{34}$ S, delta-34-sulfur; VSMOW, Vienna Standard Mean Ocean Water; CDT, Cañon Diablo Troilite. 


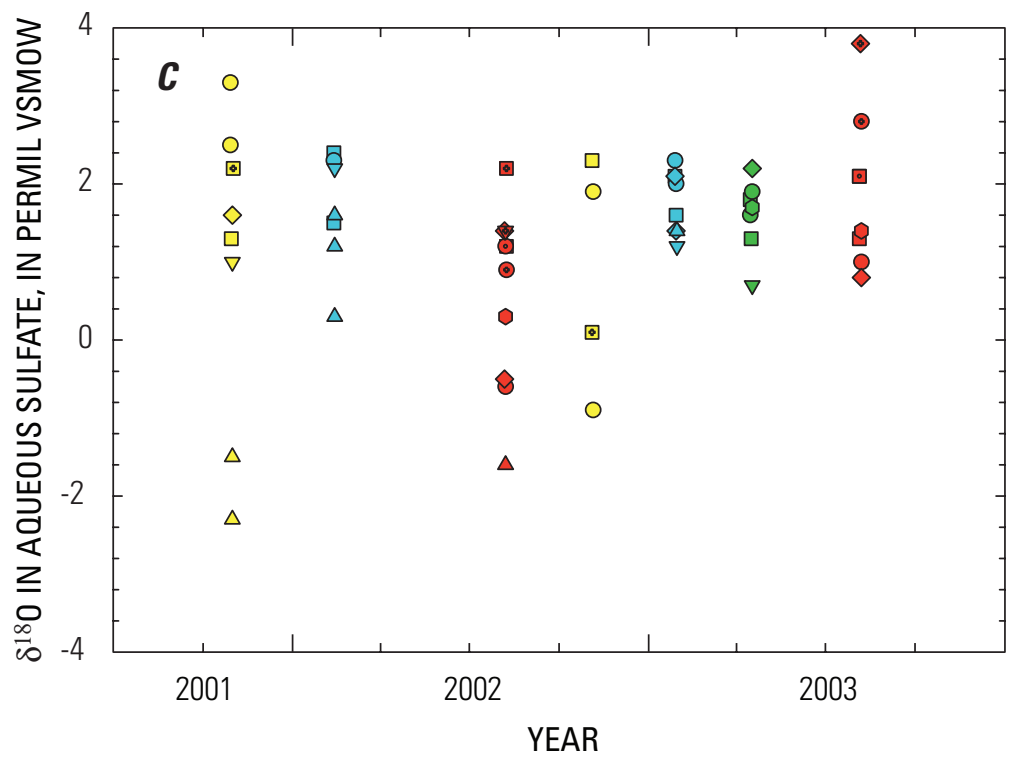

EXPLANATION

$\begin{array}{lccccc} & \text { Site Number } & \text { Fall } & \text { Winter } & \text { Spring } & \text { Summer } \\ \text { Lower reservoir } & 1,2 & \square & \square & \square & \square \\ \text { Mid-reservoir } & 3,4 & 0 & 0 & 0 & \diamond \\ \text { Bear River arm } & 5 & \diamond & \diamond & \diamond & \diamond \\ \text { Dairy Farm arm } & 6 & \nabla & \nabla & \nabla & \nabla \\ \text { Rock Creek arm } & 7 & 0 & 0 & \bullet & \diamond \\ \begin{array}{l}\text { Dairy Farm Mine } \\ \text { pit lake and }\end{array} & 8,9 & \Delta & \Delta & \Delta & \Delta \\ \text { impoundments } & \square \circ \diamond \nabla & \text { Solid symbol indicates epilimnion } & \\ & \square \odot & \text { Dot indicates metalimnion } & \\ & \square \odot \diamond \nabla & \text { Cross indicates hypolimnion }\end{array}$

Figure 11. Continued. 

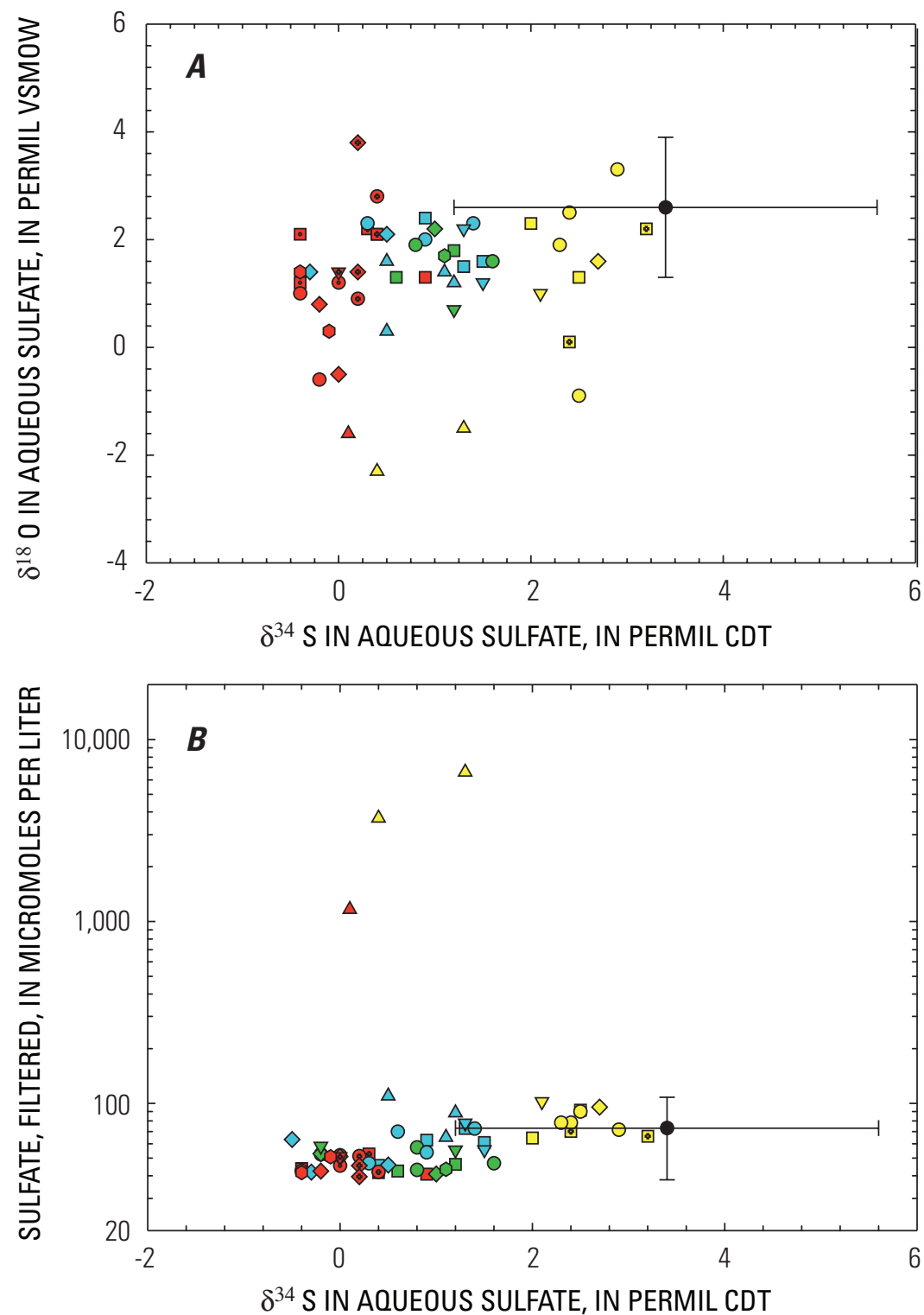

EXPLANATION

$\begin{array}{lccccc} & \text { Site Number } & \text { Fall } & \text { Winter } & \text { Spring } & \text { Summer } \\ \text { Lower reservoir } & 1,2 & \square & \square & \square & \square \\ \text { Mid-reservoir } & 3,4 & 0 & \circ & \circ & \bullet \\ \text { Bear River arm } & 5 & \diamond & \diamond & \diamond & \diamond \\ \text { Dairy Farm arm } & 6 & \nabla & \nabla & \nabla & \nabla \\ \text { Rock Creek arm } & 7 & \bullet & \bullet & \bullet & \bullet \\ \begin{array}{l}\text { Dairy Farm Mine } \\ \text { pit lake and }\end{array} & 8,9 & \Delta & \Delta & \Delta & \Delta \\ \text { impoundments } & \square \circ \diamond \nabla & \text { Solid symbol indicates epilimnion } & \\ & \square \odot & \text { Dot indicates metalimnion } & \\ & \square \odot \diamond \nabla & \text { Cross indicates hypolimnion }\end{array}$

Figure 12. Relations between sulfur isotopes in aqueous sulfate and other water-quality constituents in Camp Far West Reservoir, California, 2001-03: $(A)$ Oxygen isotopes in aqueous sulfate, $(B)$ Sulfate concentration in filtered water, $(C)$ Calcium concentration in filtered water. Filled, black circle with error bars represents average concentrations and standard deviations for eight fallseason samples collected at approximately monthly intervals from the Bear River below Wolf Creek near Lucas Hill (USGS station 390107121102101). $\delta^{18} 0$, delta-18-oxygen; $\delta^{34}$ S, delta-34-sulfur; VSMOW, Vienna Standard Mean Ocean Water; CDT, Cañon Diablo Troilite. 


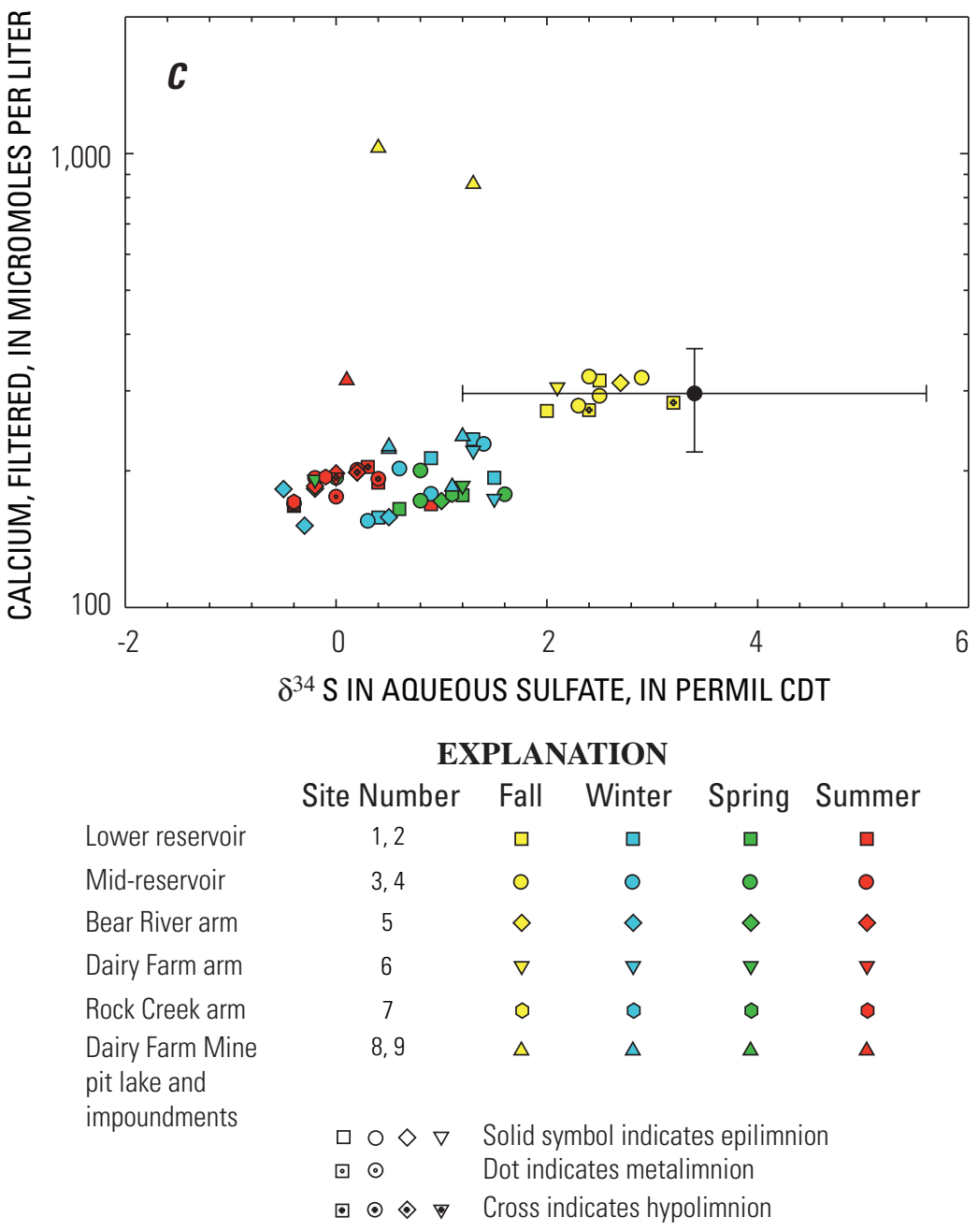

Figure 12. Continued. 

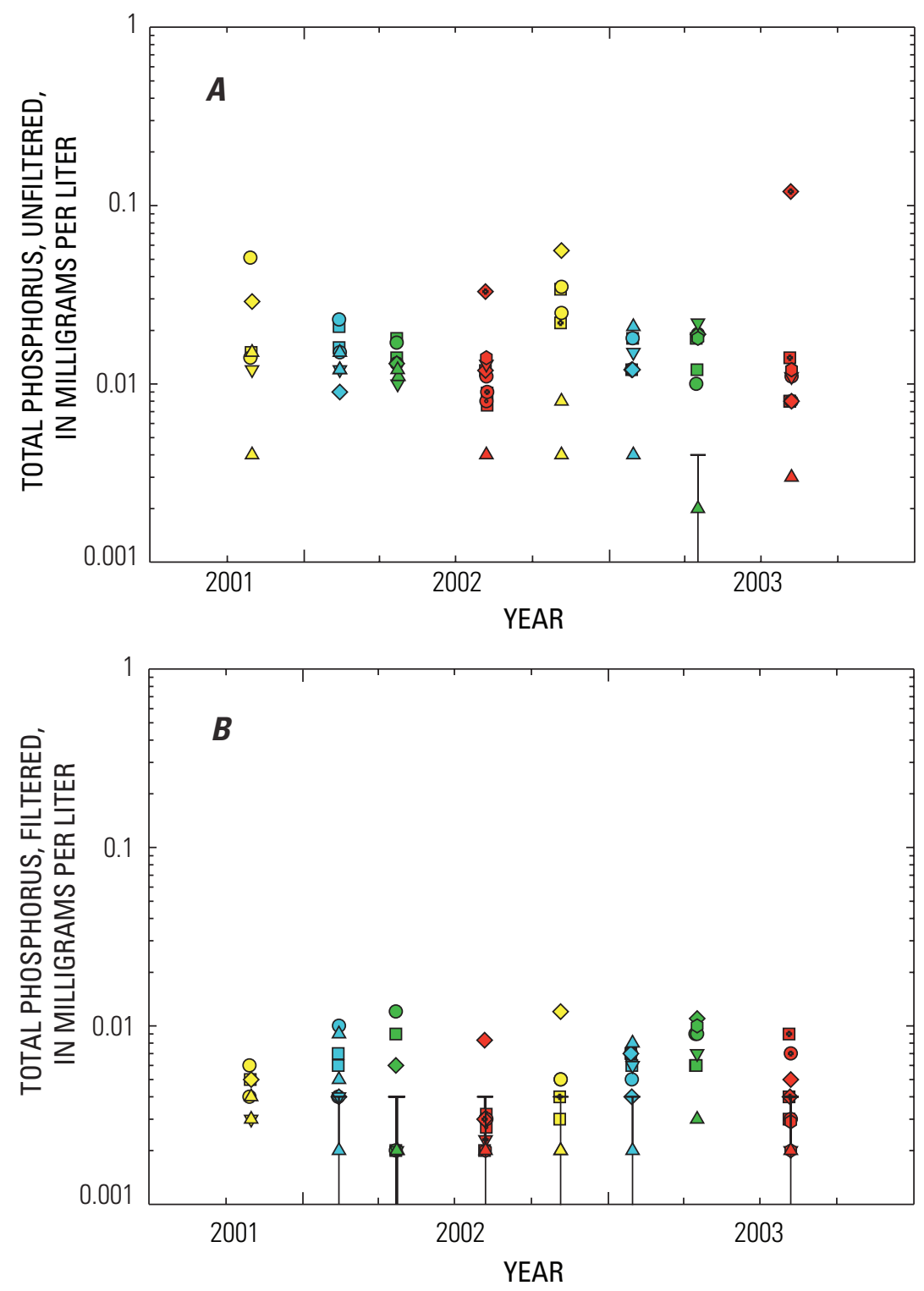

EXPLANATION

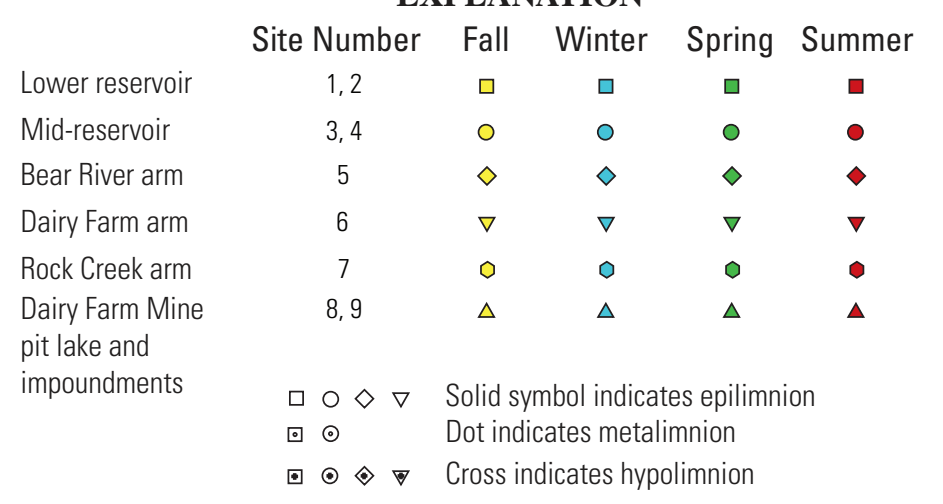

Figure 13. Total phosphorus concentrations in Camp Far West Reservoir, California, 2001-03: $(A)$ Unfiltered water, $(B)$ Filtered water, $(C)$ Particulate. Particulate total phosphorus concentrations calculated as difference between total phosphorus in unfiltered water and total phosphorus in filtered water. Error bars represent measurements less than method detection limit (MDL), with corresponding symbol plotted at 50 percent of MDL. 


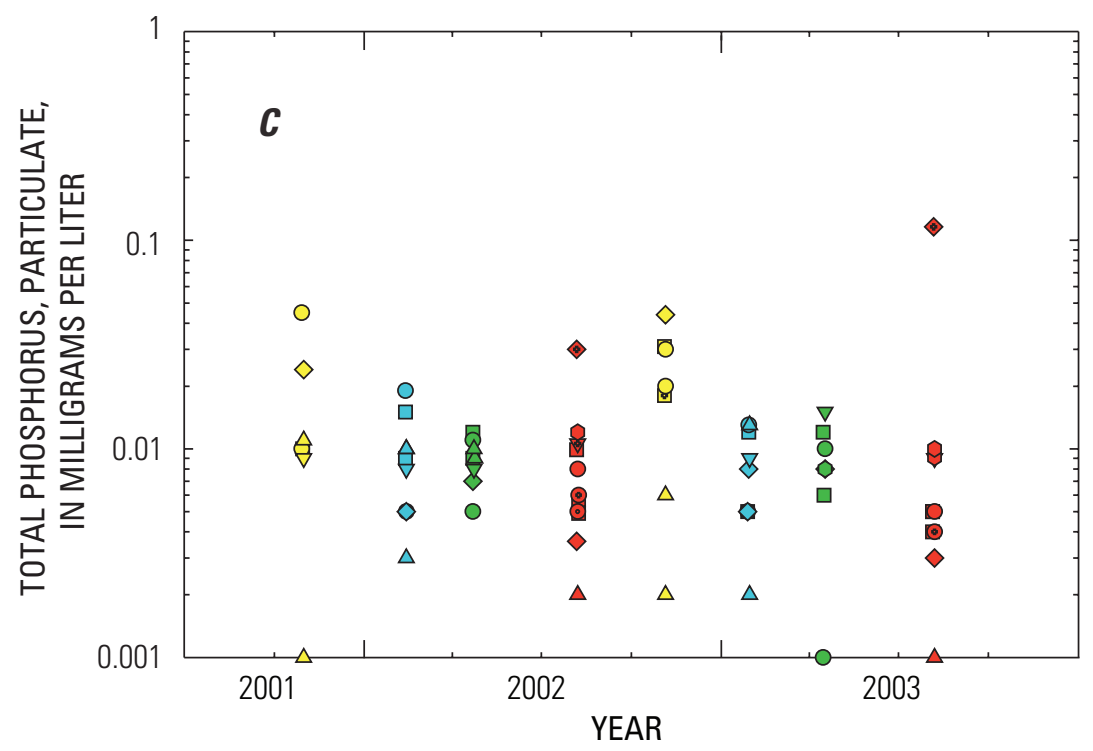

\begin{tabular}{|c|c|c|c|c|c|}
\hline & \multicolumn{4}{|c|}{ EXPLANATION } & \multirow{3}{*}{$\begin{array}{c}\text { Summer } \\
\square\end{array}$} \\
\hline & Site Number & Fall & Winter & Spring & \\
\hline Lower reservoir & 1,2 & $\square$ & $\square$ & $\square$ & \\
\hline Mid-reservoir & 3,4 & O & ० & o & ○ \\
\hline Bear River arm & 5 & $\diamond$ & $\diamond$ & $\diamond$ & $\diamond$ \\
\hline Dairy Farm arm & 6 & $\nabla$ & $\nabla$ & $\nabla$ & $\nabla$ \\
\hline Rock Creek arm & 7 & 0 & 0 & 0 & 0 \\
\hline Dairy Farm Mine & 8,9 & $\Delta$ & $\Delta$ & $\Delta$ & $\Delta$ \\
\hline impoundments & $\begin{array}{l}\square \circ \diamond \nabla \\
\oslash \odot\end{array}$ & $\begin{array}{l}\text { Solid } \\
\text { Dot ir }\end{array}$ & $\begin{array}{l}\text { abol indic } \\
\text { ates metc }\end{array}$ & $\begin{array}{l}\text { es epilimn } \\
\text { nnion }\end{array}$ & \\
\hline
\end{tabular}

Figure 13. Continued.

Results for ammonia plus organic nitrogen in unfiltered and filtered water, and ammonia in filtered water (table 5), indicate that very little to no ammonia is present at sampling sites 1-7. In contrast, sites 8 and 9 had elevated ammonia concentrations associated with acid mine drainage. At sites 1-7, the dominant form of $\mathrm{N}$ is organic. Time-series plots of ammonia plus organic nitrogen in unfiltered and filtered water (figs. 14A-14B, respectively) indicate that the fall samples have the most elevated concentrations, with a declining trend from fall to winter to spring to summer. A time-series plot of nitrate plus nitrite (fig. 14C) indicates that non-detect values occurred only during summer and fall. Concentrations of nitrite plus nitrate in filtered water essentially represent nitrate only, as nitrite concentrations were not detected or were very low (table 5). Nitrate concentrations spanned a fairly wide range among reservoir stations during each of the sampling events (fig. 14C).

Particulate organic carbon (fig. 15A) did not display as strong a seasonal trend as the $\mathrm{N}$ and $\mathrm{P}$ species discussed above; however the concentrations were highest during summer and fall. Dissolved organic carbon concentrations (table 5, fig. 15B) at sites 1-7 ranged from 1.5 to $3.0 \mathrm{mg} / \mathrm{L}$ and averaged 2.0 with a standard deviation of 0.58 ; concentrations were consistently greater than or equal to 2.0 at sites $1-7$ during fall.

The relation between concentrations in unfiltered and

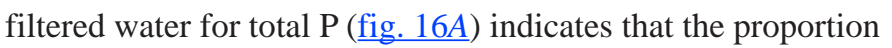
of $\mathrm{P}$ passing through the capsule (C45) filter was 10 to 67 percent for most samples. In contrast, the analogous relation for ammonia plus organic nitrogen (fig. 16B) indicates that typically 50 to 100 percent passed through the filter. The elevated ammonia concentrations in the samples from sites 8 and 9 are equal in unfiltered and filtered splits, indicating that the ammonia is in a dissolved or colloidal form. A comparison of dissolved organic carbon (DOC) with particulate organic carbon (POC) (fig. 16C) indicates that DOC concentrations are typically higher than POC concentrations by a considerable margin. Among more than 60 samples, POC concentrations exceeded DOC only once each at two sites, 5 and 8 (fig. 16C, table 5). 

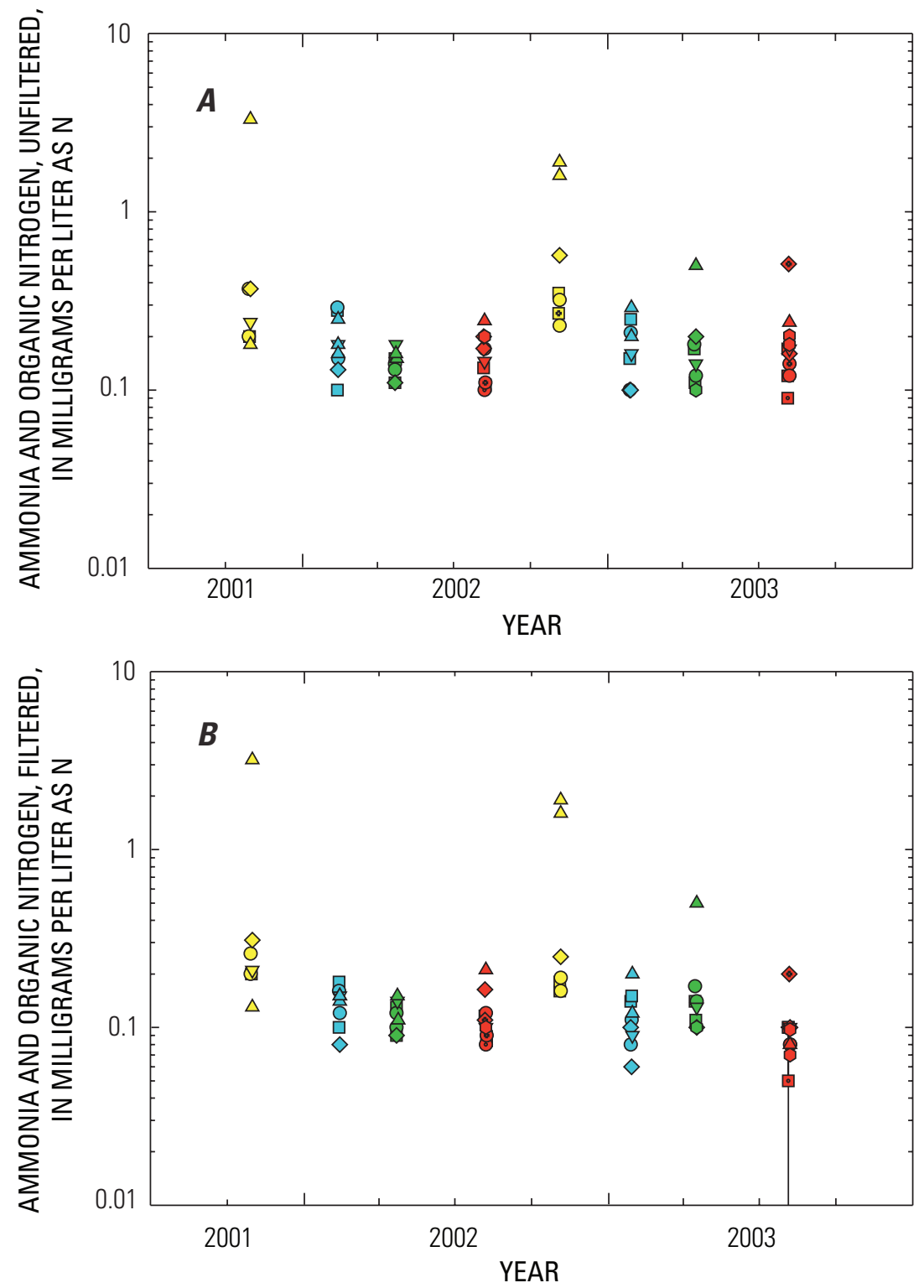

EXPLANATION

$\begin{array}{lccccc} & \text { Site Number } & \text { Fall } & \text { Winter } & \text { Spring } & \text { Summer } \\ \text { Lower reservoir } & 1,2 & \square & \square & \square & \square \\ \text { Mid-reservoir } & 3,4 & \circ & \circ & \circ & \bullet \\ \text { Bear River arm } & 5 & \diamond & \diamond & \diamond & \diamond \\ \text { Dairy Farm arm } & 6 & \nabla & \nabla & \nabla & \nabla \\ \text { Rock Creek arm } & 7 & \bullet & \bullet & \bullet & \bullet \\ \text { Dairy Farm Mine } & 8,9 & \Delta & \Delta & \Delta & \Delta \\ \text { pit lake and } & & & & & \\ \text { impoundments } & \square \circ \diamond \nabla & \text { Solid symbol indicates epilimnion } \\ & \square \odot & \text { Dot indicates metalimnion } & \\ & \square \odot \diamond \nabla & \text { Cross indicates hypolimnion }\end{array}$

Figure 14. Nitrogen species concentrations in Camp Far West Reservoir, California, 2001-03: (A) Ammonia and organic nitrogen in unfiltered water, $(B)$ Ammonia and organic nitrogen in filtered water, $(C)$ Nitrite plus nitrate in filtered water. Error bars represent measurements less than method detection limit (MDL), with corresponding symbol plotted at 50 percent of MDL. 


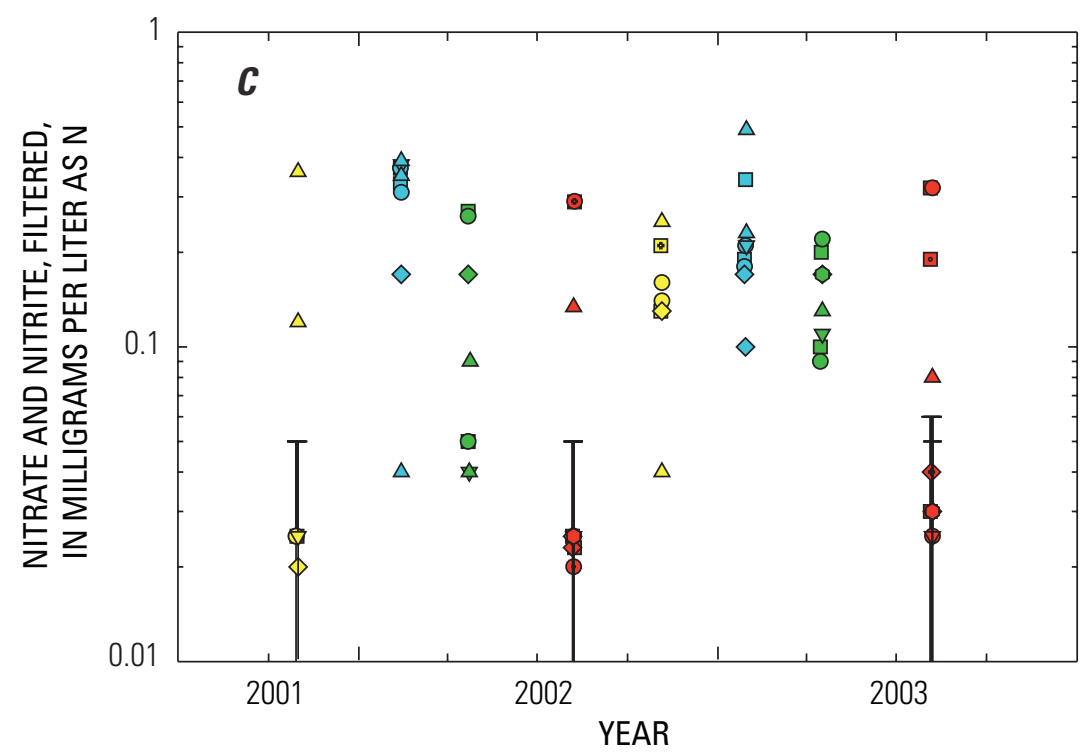

EXPLANATION

\begin{tabular}{|c|c|c|c|c|c|}
\hline Lower reservoir & $\begin{array}{c}\text { Site Number } \\
1,2\end{array}$ & $\begin{array}{c}\text { Fall } \\
\square\end{array}$ & Winter & $\begin{array}{c}\text { Spring } \\
\square\end{array}$ & Summer \\
\hline Mid-reservoir & 3,4 & o & 0 & o & ○ \\
\hline Bear River arm & 5 & $\diamond$ & $\diamond$ & $\diamond$ & $\diamond$ \\
\hline Dairy Farm arm & 6 & $\nabla$ & $\nabla$ & $\nabla$ & $\nabla$ \\
\hline Rock Creek arm & 7 & 0 & 0 & 0 & 0 \\
\hline $\begin{array}{l}\text { Dairy Farm Mine } \\
\text { pit lake and }\end{array}$ & 8,9 & $\Delta$ & $\Delta$ & $\Delta$ & $\Delta$ \\
\hline impoundments & $\begin{array}{l}\square \circ \diamond \nabla \\
\square \odot\end{array}$ & $\begin{array}{l}\text { Solid } \\
\text { Dot i }\end{array}$ & $\begin{array}{l}\text { ool indic } \\
\text { tes met }\end{array}$ & $\begin{array}{l}\text { epilim } \\
\text { nion }\end{array}$ & \\
\hline
\end{tabular}

Figure 14. Continued. 

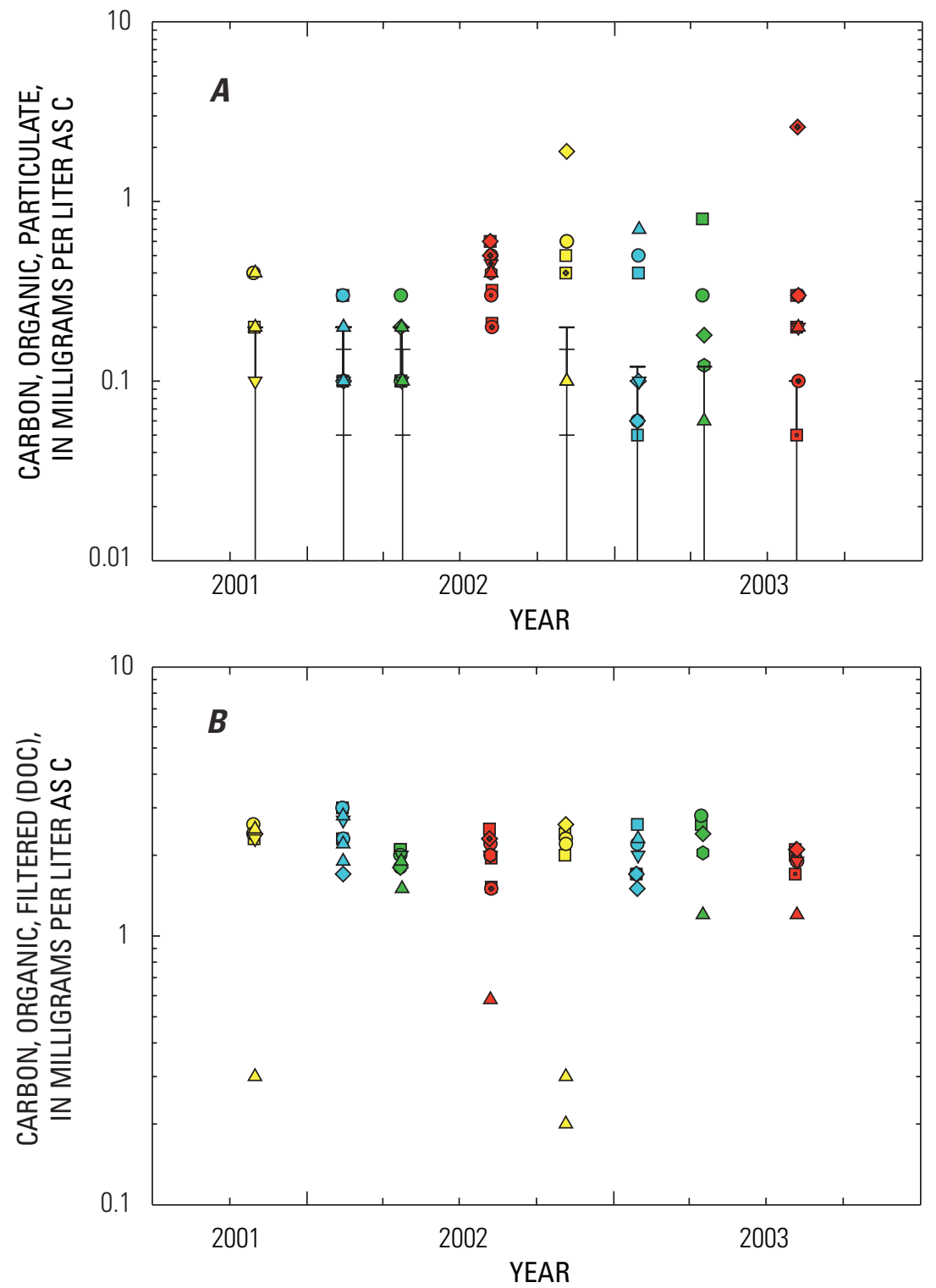

EXPLANATION

Site Number Fall Winter Spring Summer

$\begin{array}{lcccc}\text { Lower reservoir } & 1,2 & \square & \square & \square \\ \text { Mid-reservoir } & 3,4 & 0 & 0 & 0 \\ \text { Bear River arm } & 5 & \diamond & \diamond & \diamond \\ \text { Dairy Farm arm } & 6 & \nabla & \nabla & \nabla \\ \text { Rock Creek arm } & 7 & \diamond & \diamond & \bullet \\ \begin{array}{l}\text { Dairy Farm Mine } \\ \text { pit lake and }\end{array} & 8,9 & \Delta & \Delta & \Delta \\ \text { impoundments } & \square \odot \diamond \nabla & \text { Solid symbol indicates epilimnion } \\ & \square \odot & \text { Dot indicates metalimnion } \\ & \square \odot \diamond \nabla & \text { Cross indicates hypolimnion }\end{array}$

Figure 15. Carbon species concentrations in Camp Far West Reservoir, California, 2001-03: (A) Particulate organic carbon, $(B)$ Dissolved organic carbon. Error bars represent measurements less than method detection limit (MDL), with corresponding symbol plotted at 50 percent of MDL. 

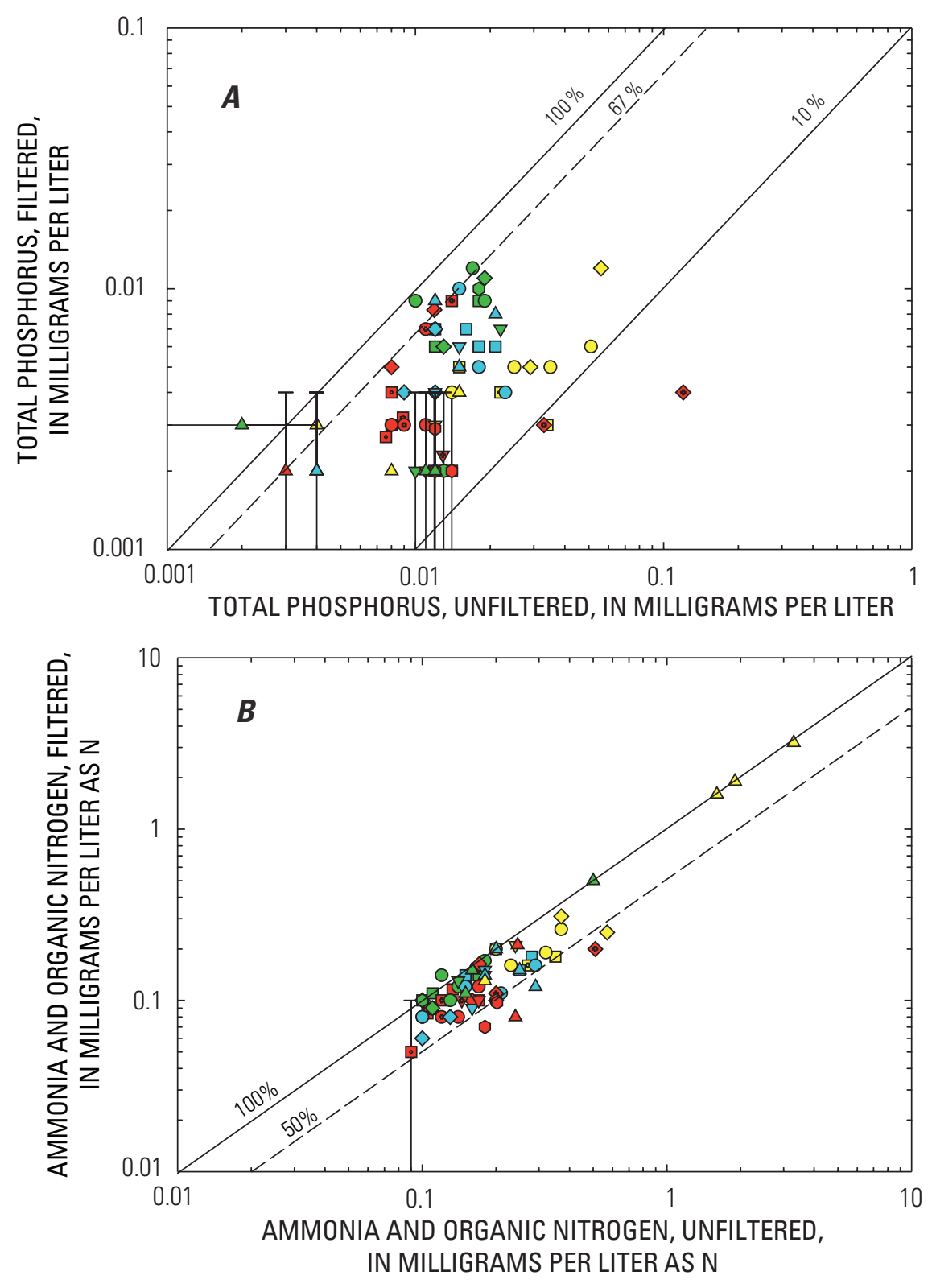

EXPLANATION

\begin{tabular}{|c|c|c|c|c|c|}
\hline Lower reservoir & $\begin{array}{c}\text { Site Number } \\
1,2\end{array}$ & $\begin{array}{c}\text { Fall } \\
\square\end{array}$ & Winter & Spring & Summer \\
\hline Mid-reservoir & 3,4 & o & 0 & ○ & ○ \\
\hline Bear River arm & 5 & $\diamond$ & $\diamond$ & $\diamond$ & $\diamond$ \\
\hline Dairy Farm arm & 6 & $\nabla$ & $\nabla$ & $\nabla$ & $\nabla$ \\
\hline Rock Creek arm & 7 & 0 & 0 & 0 & 0 \\
\hline $\begin{array}{l}\text { Dairy Farm Mine } \\
\text { pit lake and }\end{array}$ & 8,9 & $\Delta$ & $\Delta$ & $\Delta$ & $\Delta$ \\
\hline im & $\begin{array}{l}\square \circ \diamond \nabla \\
\square \odot \\
\square \odot \diamond \nabla\end{array}$ & $\begin{array}{l}\text { Solid s } \\
\text { Dot inc } \\
\text { Cross i }\end{array}$ & $\begin{array}{l}\text { ol indica } \\
\text { tes metal } \\
\text { cates hyp }\end{array}$ & $\begin{array}{l}\text { s epilim } \\
\text { inion } \\
\text { imnion }\end{array}$ & \\
\hline
\end{tabular}

Figure 16. Relations among concentrations of nutrients and carbon species in water samples from Camp Far West Reservoir, California, 2001-03: (A) Total phosphorus in unfiltered and filtered water, $(B)$ Ammonia plus organic nitrogen in unfiltered and filtered water, $(C)$ Particulate and dissolved organic carbon. In $(A)$ and $(B)$, diagonal lines indicate percentage of constituent passing through the filter. In $(C)$, diagonal line indicates equal amounts of particulate and dissolved species. Error bars represent measurements less than method detection limit (MDL), with corresponding symbol plotted at 50 percent of MDL. 


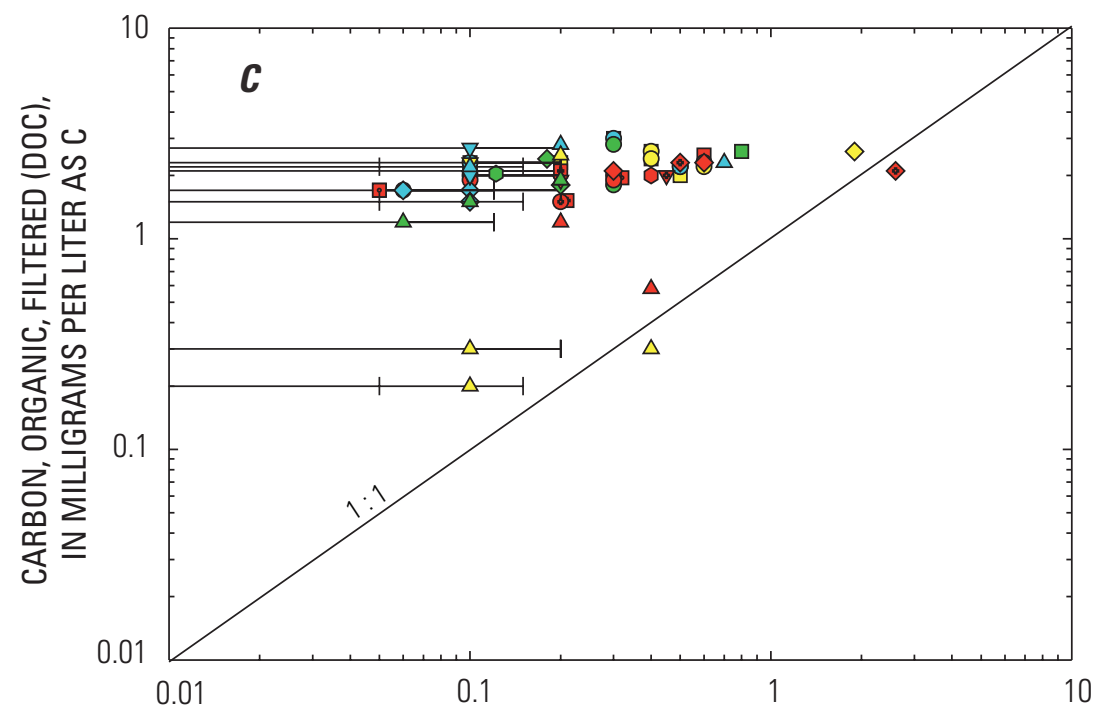

CARBON, ORGANIC, PARTICULATE, IN MILLIGRAMS PER LITER AS C

EXPLANATION

$\begin{array}{lccccc} & \text { Site Number } & \text { Fall } & \text { Winter } & \text { Spring } & \text { Summer } \\ \text { Lower reservoir } & 1,2 & \square & \square & \square & \square \\ \text { Mid-reservoir } & 3,4 & \circ & 0 & \circ & \circ \\ \text { Bear River arm } & 5 & \diamond & \diamond & \diamond & \diamond \\ \text { Dairy Farm arm } & 6 & \nabla & \nabla & \nabla & \nabla \\ \text { Rock Creek arm } & 7 & \diamond & \diamond & \diamond & \diamond \\ \text { Dairy Farm Mine } & 8,9 & \Delta & \Delta & \Delta & \Delta \\ \text { pit lake and } & & & & \\ \text { impoundments } & \square \circ \diamond \nabla & \text { Solid symbol indicates epilimnion } & \\ & \bullet \odot & \text { Dot indicates metalimnion } & \\ & \bullet \odot \diamond \nabla & \text { Cross indicates hypolimnion }\end{array}$

Figure 16. Continued.

The relative abundance of various forms of $\mathrm{N}$ and $\mathrm{P}$ are useful in determining limiting factors with regard to nutrient cycling and primary production of phytoplankton in aquatic system including freshwater reservoirs such as CFWR. The most biologically active forms of nutrients with regard to use by phytoplankton are inorganic $\mathrm{N}$ (primarily nitrate, nitrite, and ammonia) and inorganic $\mathrm{P}$ (orthophosphate, $\mathrm{PO}_{4}{ }^{3-}$ ). Using the data of Kuwabara and others (2003) for orthophosphate and total inorganic nitrogen (nitrite and nitrate, plus ammonia) in filtered water, N-to-P molar ratios between 136 and greater than 2,600 were computed (table 5, fig. 17A) for the three CFWR stations sampled in April and November 2002. These values are about one to two orders of magnitude greater than the Redfield N-to-P molar ratio of 16 (Wetzel, 2001), and hence are an unequivocal indication of P-limitation. Samples collected for the present study had mostly detectable concentrations of total inorganic nitrogen but no detectable concentrations of orthophosphate in nearly all samples (table 6) consistent with the elevated N-to-P ratios found by Kuwabara and others (2003).
The relation between total $\mathrm{P}$ and $\mathrm{NH}_{3}+\mathrm{N}$-org in unfiltered water (fig. 17B) for samples from sites 1-7 shows a generally positive correlation. Ammonium concentrations were minimal in samples from sites $1-7$, so $\mathrm{NH}_{3}+\mathrm{N}$-org concentrations represent primarily organic nitrogen at these sites. A linear least-squares regression (excluding data from stations DFP and $\mathrm{DFI}$ ) in log-transformed coordinates gives an $\mathrm{R}^{2}$ value of 0.57 . Values of the N:P molar ratio for these nutrients ranged from about 10 to 50, with most values greater than the Redfield ratio of 16. The equivalent data for filtered samples (fig. 17C) do not indicate a correlation between total $\mathrm{P}$ and $\mathrm{NH}_{3}+\mathrm{N}$-org concentrations. The N:P molar ratios for the filtered samples are between 16 and about 200. The overall seasonal trend both for total $\mathrm{P}$ and for $\mathrm{NH}_{3}+\mathrm{N}$-org is a general decline from fall to winter to spring to summer. This depletion in nutrients could be caused by uptake in organisms, primarily phytoplankton, starting with a bloom in the fall (Stewart and others, 2008). 


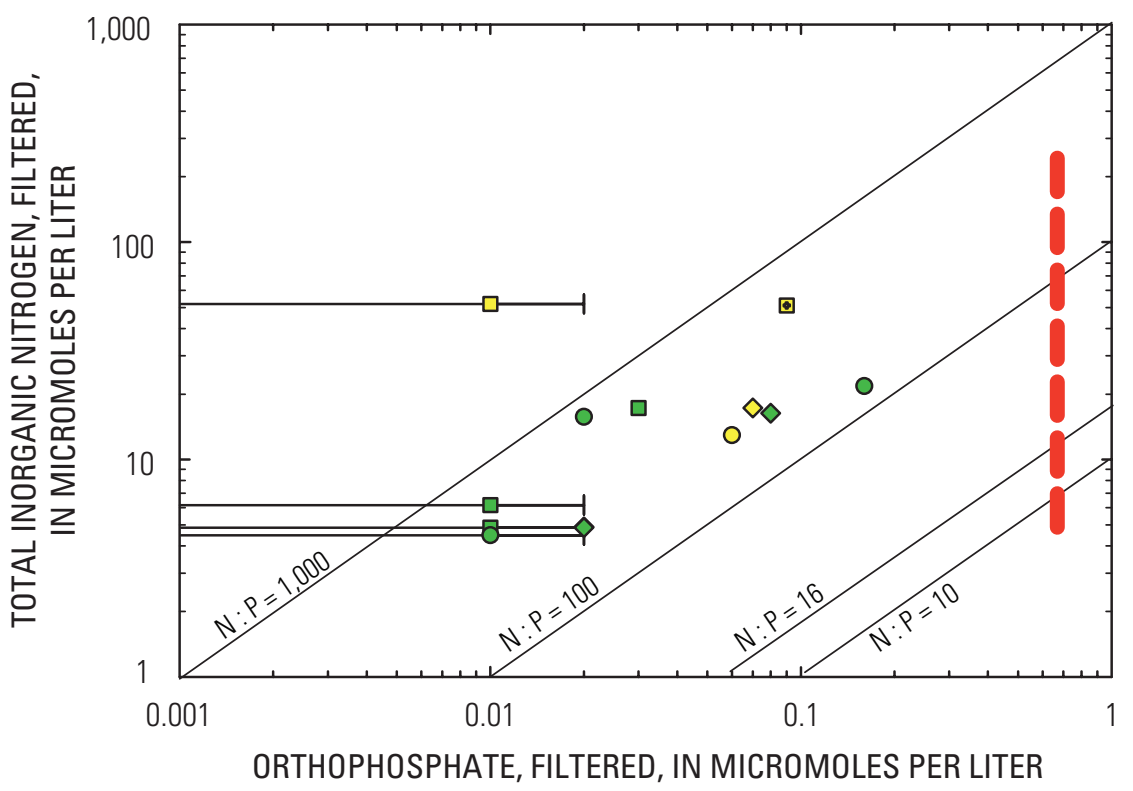

EXPLANATION

Data from Kuwabara and others (2003a):

Lower reservoir
Mid-reservoir

Figure 17. Relations between concentrations of phosphorus and nitrogen compounds in water samples from Camp Far West Reservoir, California, 2001-03: $(A)$ total inorganic nitrogen and orthophosphate in filtered water (data from Kuwabara and others, 2003), (B) ammonia plus organic nitrogen and total phosphorus in unfiltered water, $(C)$ ammonia plus organic nitrogen and total phosphorus in filtered water. Diagonal lines indicate constant values of the molar ratio of nitrogen $(N)$ to phosphorus $(P)$. In $(A)$, total inorganic nitrogen calculated as sum of nitrite, nitrate, and ammonia. Error bars represent measurements less than method detection limit (MDL), with corresponding symbol plotted at 50 percent of MDL.

At reservoir sites 1-7, the two dominant forms of nitrogen were nitrate and organic $\mathrm{N}$ (table 5). A comparison of these two constituents in filtered water indicates that nitrate was more abundant than organic $\mathrm{N}$ during winter sampling events at all sites, whereas the organic $\mathrm{N}$ was apparently more abundant than nitrate at most stations during the fall. Results for spring and summer varied more than the other seasons. 

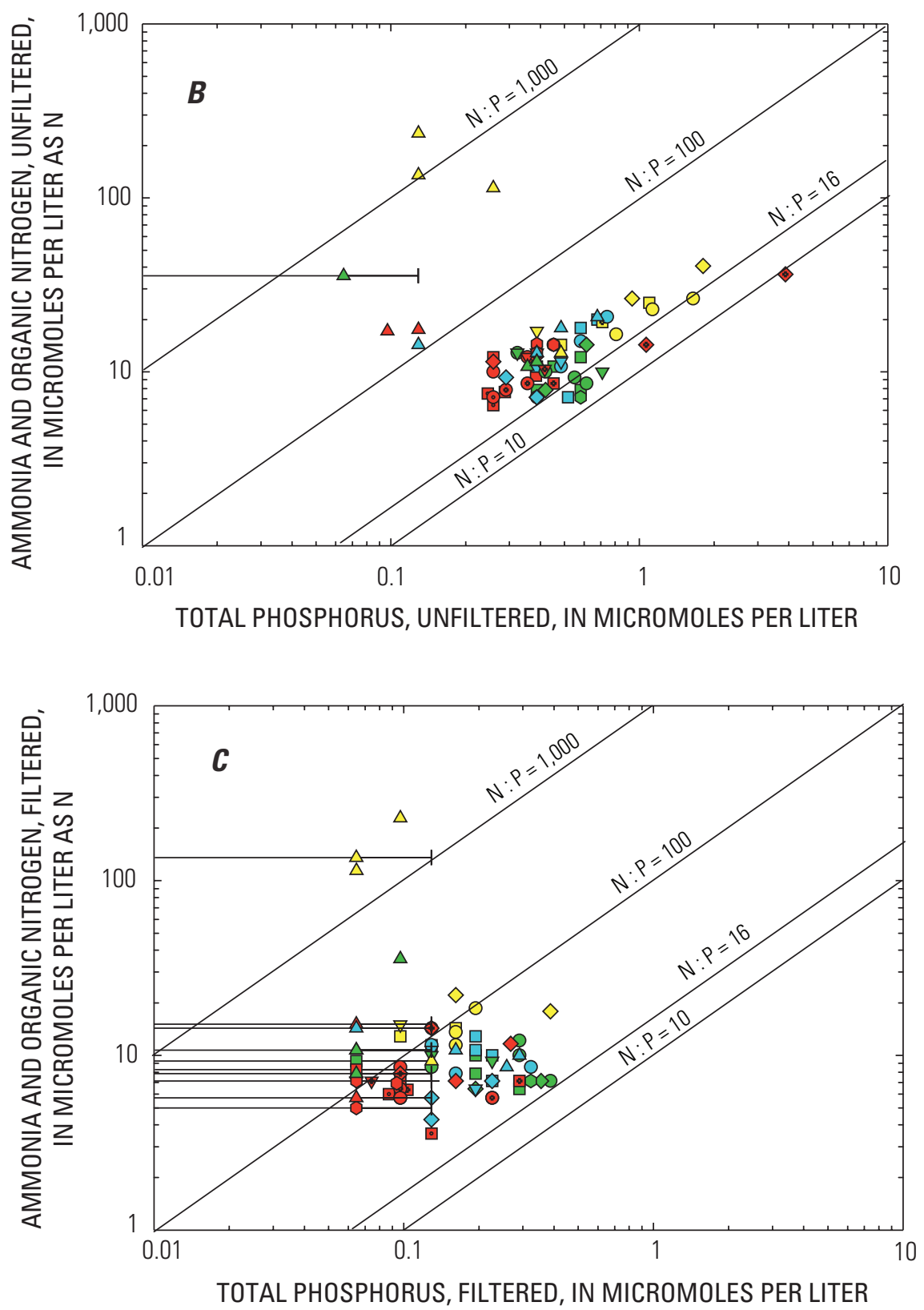

EXPLANATION

$\begin{array}{lccccc}\text { Lower reservoir } & 1,2 & \square & \square & \square & \square \\ \text { Mid-reservoir } & 3,4 & 0 & \circ & \circ & \circ \\ \text { Bear River arm } & 5 & \diamond & \diamond & \diamond & \diamond \\ \text { Dairy Farm arm } & 6 & \nabla & \nabla & \nabla & \nabla \\ \text { Rock Creek arm } & 7 & \diamond & 0 & \bullet & \bullet \\ \begin{array}{l}\text { Dairy Farm Mine } \\ \text { pit lake and }\end{array} & 8,9 & \Delta & \Delta & \Delta & \Delta \\ \text { impoundments } & \square \circ \diamond \nabla & \text { Solid symbol indicates epilimnion } \\ & \square \odot & \text { Dot indicates metalimnion } & \\ & \square \odot \diamond \nabla & \text { Cross indicates hypolimnion }\end{array}$

Figure 17. Continued. 


\section{Mercury and Methylmercury}

The data for total mercury in filtered and unfiltered water samples (table 6) are a compilation of best values based on multiple sample-processing approaches. In cases where data for unfiltered samples were not available, the sum of filtrate and particulate concentrations from the quartz fiber filter was used, as discussed previously in the Quality Assurance section. Raw data for $\mathrm{Hg}_{\mathrm{T}}$ in unfiltered, filtered, and particulate samples are given in appendix G; data for unfiltered samples are given in table $\mathrm{G} 1$ and data for $\mathrm{Hg}_{\mathrm{T}}$ in filtered and particulate samples are given in table G2. The values for particulate $\mathrm{Hg}_{\mathrm{T}}$ in table 6 are consistent with the difference between the filtered and unfiltered analyses. Statistical data for $\mathrm{Hg}_{\mathrm{T}}, \mathrm{MeHg}$, and $\mathrm{MeHg} / \mathrm{Hg}_{\mathrm{T}}$ in unfiltered, filtered, and particulate samples are given in table 9 .

The time-series plots of best values of unfiltered, filtered, and particulate $\mathrm{Hg}_{\mathrm{T}}$ (figs. 18A-18C, respectively) show systematic seasonal trends. Unfiltered total mercury concentrations (fig. 18A) were highest at most stations during the fall and winter, and declined during spring and summer. Filtered $\mathrm{Hg}_{\mathrm{T}}$ concentrations (fig. 18B) followed a somewhat different seasonal pattern than the unfiltered concentrations, higher at most stations during winter and spring and lower during summer and fall. Particulate $\mathrm{Hg}_{\mathrm{T}}$ concentrations (fig. 18C) showed a systematic decrease from fall to winter to spring to summer at most stations.

Time-series plots for unfiltered, filtered, and particulate $\mathrm{MeHg}$ (figs. 18D-18F, respectively) show a seasonal trend that is generally opposite of that for $\mathrm{Hg}_{\mathrm{T}}$ - the $\mathrm{MeHg}$ concentrations increase at most sites from fall to winter to spring. MeHg concentrations during summer are highly variable but include the highest values for unfiltered and filtered MeHg recorded during the study at a time when $\mathrm{Hg}_{\mathrm{T}}$ concentrations are generally at a minimum.

Plots of the relation between concentrations in unfiltered and filtered constituents can be used for two purposes-as a quality control check (the filtered concentrations should always be lower) and to ascertain the proportion of the constituent that passes through the filter. The proportion passing through the filter is an approximation of the dissolved phase; however, this terminology is not used in this report with the exception of carbon and sulfate. With regard to mercury and other trace metals, it is likely that a significant part of the material passing through the filter consists of colloidal particles smaller than the filter pore size (for example, see Alpers and others, 2000; Roth and others, 2001; Choe and Gill, 2001, 2003; Choe and others, 2003). Metals associated with the dissolved and colloidal phases generally are more biologically available than metals associated with coarser particulates. A plot of unfiltered versus filtered concentrations for $\mathrm{Hg}_{\mathrm{T}}$ (fig. 19A) indicates that about 10 to 50 percent of the mercury passed through the capsule (C45) filter at most stations during winter and spring, whereas less than 10 percent of the mercury was filterable at several of the stations during fall and at a smaller number of stations during summer. A similar plot for MeHg (fig. 19B) indicates that about 50 percent passed through the filter for most of the samples for which $\mathrm{MeHg}$ was detected in unfiltered and filtered water.

The ratio of $\mathrm{MeHg}$ to $\mathrm{Hg}_{\mathrm{T}}\left(\mathrm{MeHg} / \mathrm{Hg}_{\mathrm{T}}\right)$ is a useful quantity for assessing mercury geochemistry because it normalizes $\mathrm{MeHg}$ concentration to the amount of $\mathrm{Hg}_{\mathrm{T}}$ present. Values of $\mathrm{MeHg} / \mathrm{Hg}_{\mathrm{T}}$ in water or sediment can reflect the methylation efficiency of a watershed (for example, Krabbenhoft and others, 1999). In water samples for which the value of MeHg was a non-detect, a maximum value of the ratio can be computed. Scatter plots showing the concentrations of $\mathrm{Hg}_{\mathrm{T}}$ and $\mathrm{MeHg}$ for unfiltered (fig. 20A) and filtered (fig. 20B) samples indicate that values of $\mathrm{MeHg} / \mathrm{Hg}_{\mathrm{T}}$ are most commonly between about 1 and 10 percent. The seasonal trend in $\mathrm{MeHg} / \mathrm{Hg}_{\mathrm{T}}$ that is apparent from the color of the symbols in figure 20 can be seen even more clearly in the time series plots of figure 21. Considering all CFWR stations, the maximum values of $\mathrm{MeHg} / \mathrm{Hg}_{\mathrm{T}}$ in unfiltered water increased systematically from winter to spring to summer, and the minimum values of $\mathrm{MeHg} / \mathrm{Hg}_{\mathrm{T}}$ increased from fall to winter to spring and then decreased during summer (fig. 21A). Seasonal variations $\mathrm{MeHg} / \mathrm{Hg}_{\mathrm{T}}$ in filtered water (fig. 21B) were similar to the trends for unfiltered water during 2002 but the trends during 2003 were less systematic.

A comparison of $\mathrm{MeHg} / \mathrm{Hg}_{\mathrm{T}}$ values for unfiltered and filtered samples (fig. 22) indicates that the values in filtered samples are systematically higher. A linear leastsquares regression using 24 data points with detected values ( $\underline{\text { fig. } 22 A}$ ) has a slope of 3.6 and an intercept near the origin $\left(\mathrm{R}^{2}=0.89\right)$; a similar regression excluding the data point with the highest values has a slope of 2.5 with a reduced value of the correlation coefficient $\left(\mathrm{R}^{2}=0.56\right)$. A plot of the same data on logarithmic axes (fig. 22B) shows that the winter samples are tightly clustered, whereas the summer data extend to high values of the ratio for both unfiltered and filtered in close proportion to the overall slope. Some of the spring data points deviate from the relation, with approximately equal values of $\mathrm{MeHg} / \mathrm{Hg}_{\mathrm{T}}$ for unfiltered and filtered splits. The overall result that $\mathrm{MeHg} / \mathrm{Hg}_{\mathrm{T}}$ value is higher for filtered samples is consistent with the observation that proportionately more MeHg than $\mathrm{Hg}_{\mathrm{T}}$ passes through the filter (figs. 19A-19B). 


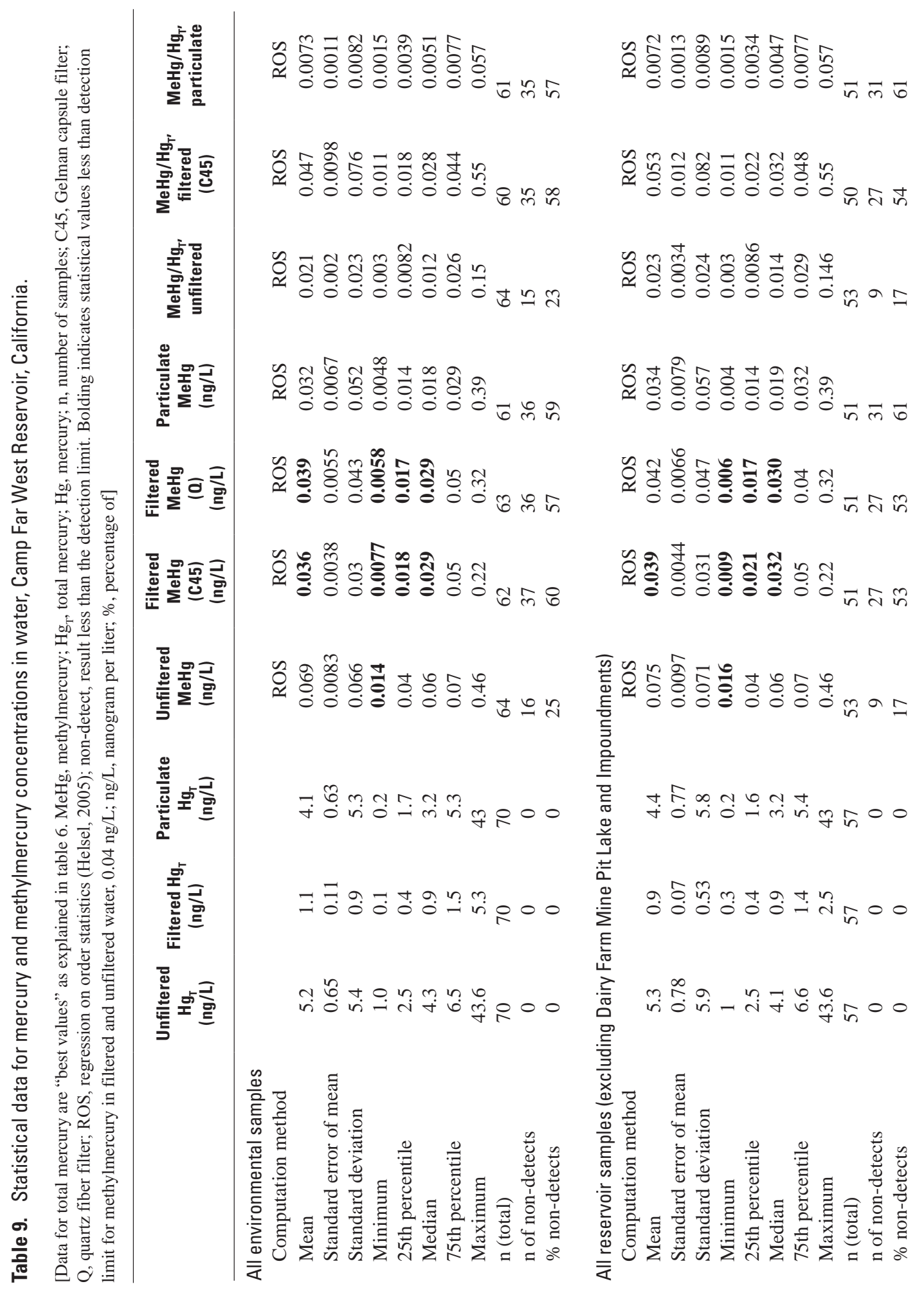




\begin{tabular}{|c|c|c|}
\hline $\begin{array}{l}\frac{1}{\bar{a}} \\
\frac{\mathbf{a}}{\mathrm{d}}\end{array}$ & 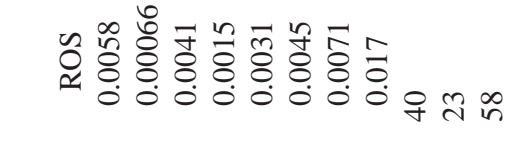 & 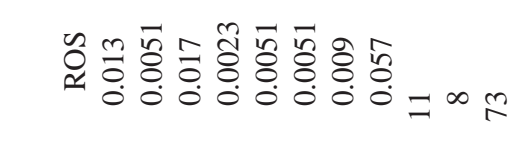 \\
\hline$\stackrel{ \pm}{ \pm}$ & 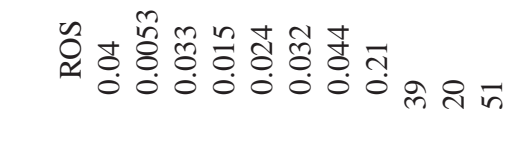 & 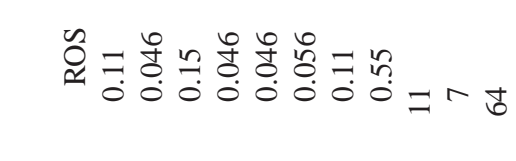 \\
\hline 농 t둔 & 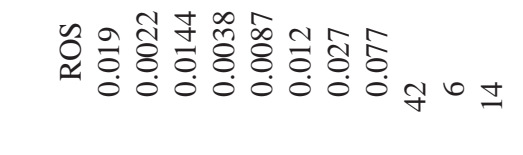 & 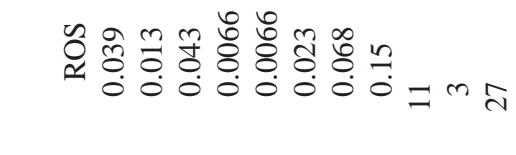 \\
\hline $\begin{array}{l}\frac{\pi}{5} \\
=\end{array}$ & 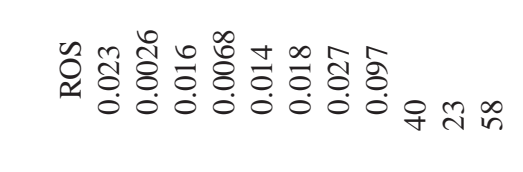 & 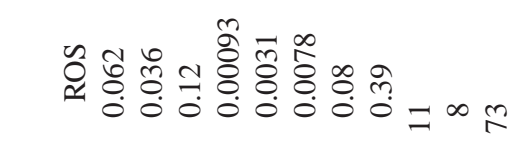 \\
\hline & 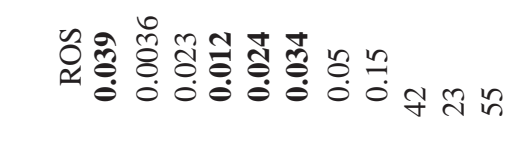 & थै \\
\hline & 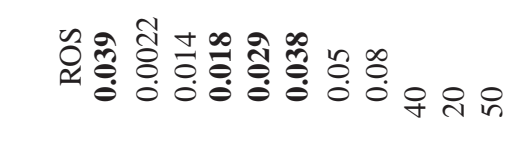 & 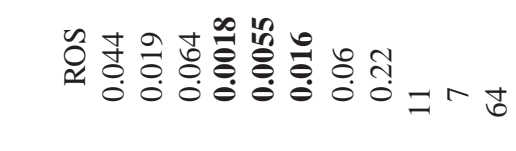 \\
\hline & 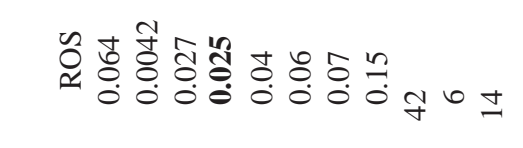 & 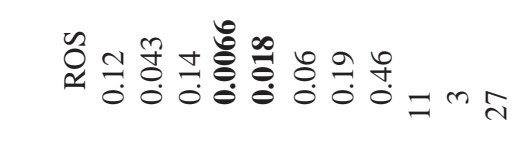 \\
\hline & 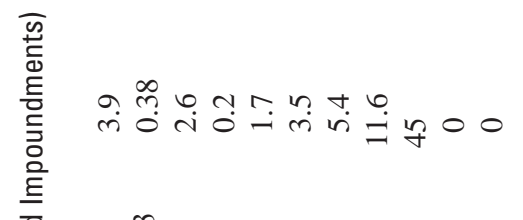 & $y \geq 00$ \\
\hline & 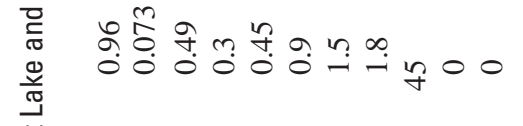 & 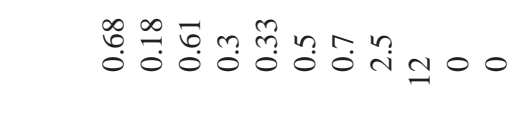 \\
\hline 흘호일 & 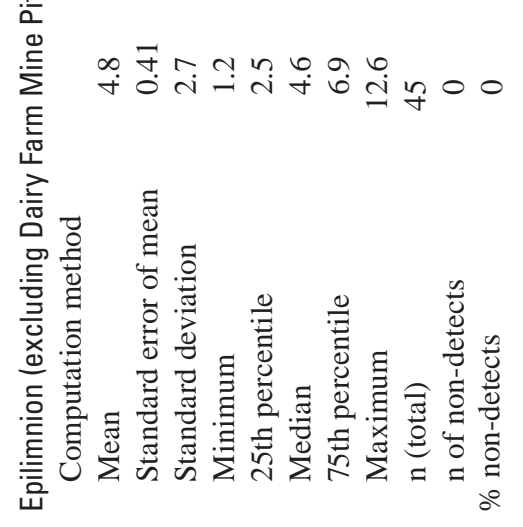 & 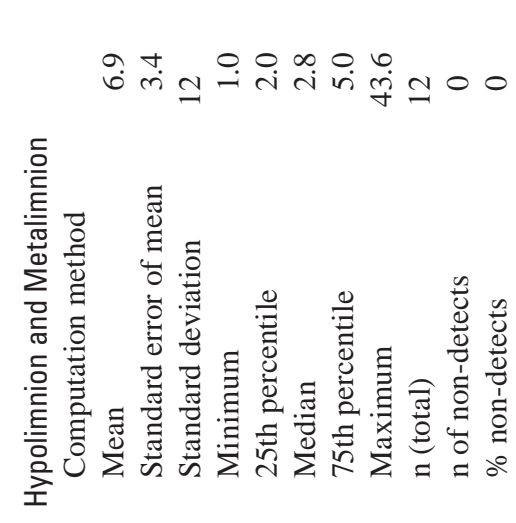 \\
\hline
\end{tabular}



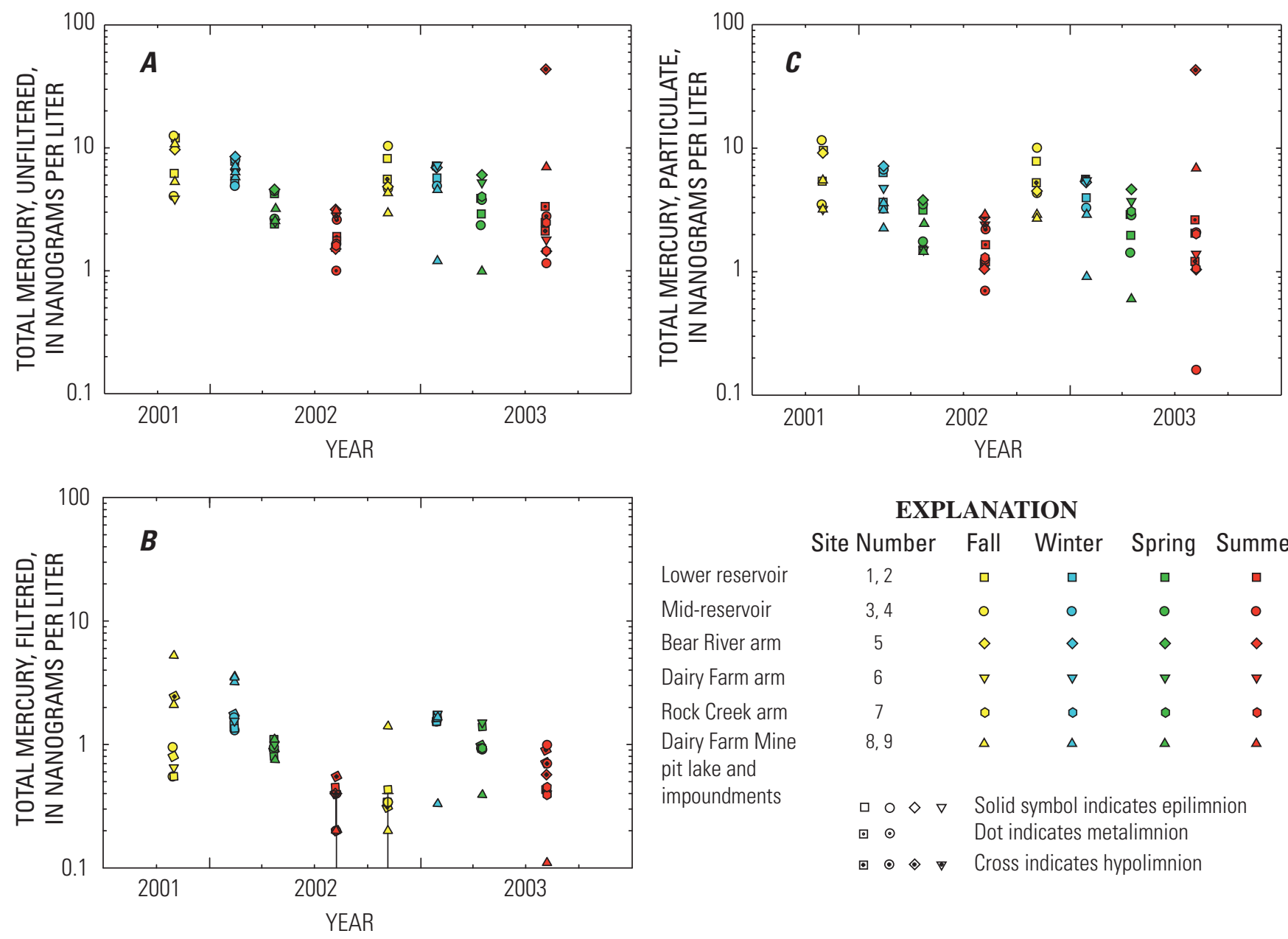

EXPLANATION

$\begin{array}{lccccc} & \text { Site Number } & \text { Fall } & \text { Winter } & \text { Spring } & \text { Summer } \\ \text { Lower reservoir } & 1,2 & \square & \square & \square & \square \\ \text { Mid-reservoir } & 3,4 & \circ & \circ & \bullet & \bullet \\ \text { Bear River arm } & 5 & \diamond & \diamond & \diamond & \diamond \\ \text { Dairy Farm arm } & 6 & \nabla & \nabla & \nabla & \nabla \\ \text { Rock Creek arm } & 7 & \diamond & \bullet & \bullet & \bullet \\ \begin{array}{l}\text { Dairy Farm Mine } \\ \text { pit lake and }\end{array} & 8,9 & \Delta & \Delta & \Delta & \Delta \\ \text { impoundments } & \square \circ \diamond \nabla & \text { Solid symbol indicates epilimnion } \\ & \square \odot & \text { Dot indicates metalimnion } & \\ & \square \odot \diamond \nabla & \text { Cross indicates hypolimnion }\end{array}$

Figure 18. Concentrations of mercury and methylmercury species for sampling stations in Camp Far West Reservoir, California, 2001-03: $(A)$ Total mercury in unfiltered water, $(B)$ Total mercury in filtered water, $(C)$ Total mercury, particulate, $(D)$ Methylmercury in unfiltered water, $(E)$ Methylmercury in filtered water, $(F)$ Methylmercury, particulate. In $(A),(B)$, and $(C)$, best values of total mercury used, as explained in text and in table 6. In (E), capsule filter data used (table 7). Error bars represent measurements less than method detection limit (MDL), with corresponding symbol plotted at 50 percent of MDL. 

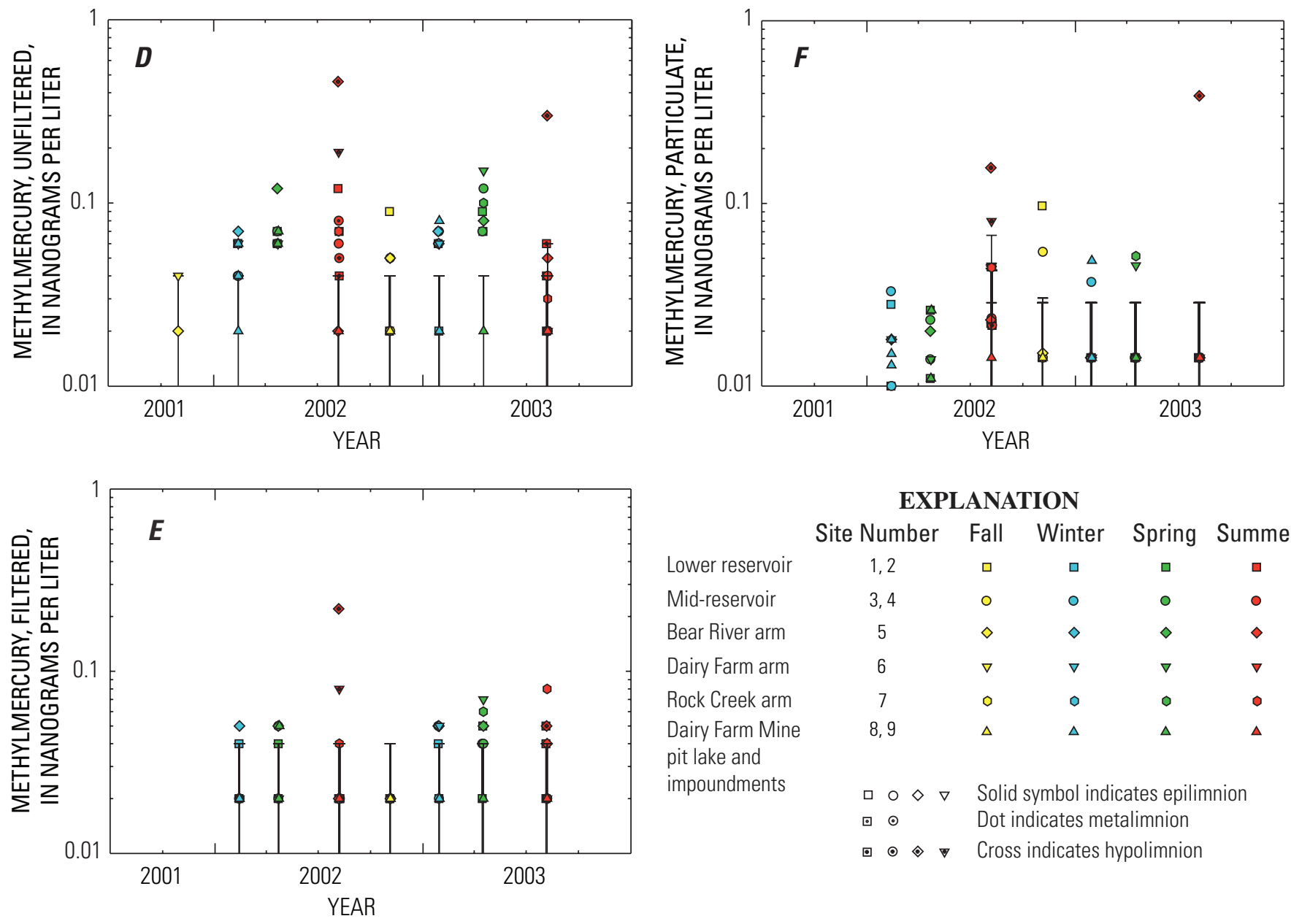

EXPLANATION

$\begin{array}{lccccc}\text { Lower reservoir } & 1,2 & \square & \square & \square & \square \\ \text { Mid-reservoir } & 3,4 & \circ & \circ & \circ & \bullet \\ \text { Bear River arm } & 5 & \diamond & \diamond & \diamond & \diamond \\ \text { Dairy Farm arm } & 6 & \nabla & \nabla & \nabla & \nabla \\ \text { Rock Creek arm } & 7 & \bullet & \bullet & \bullet & \bullet \\ \begin{array}{l}\text { Dairy Farm Mine } \\ \text { pit lake and }\end{array} & 8,9 & \Delta & \Delta & \Delta & \Delta \\ \text { impoundments } & \square \odot \diamond \nabla & \text { Solid symbol indicates epilimnion } \\ & \square \odot & \text { Dot indicates metalimnion } \\ & \square \odot \diamond \nabla & \text { Cross indicates hypolimnion }\end{array}$

Figure 18. Continued. 

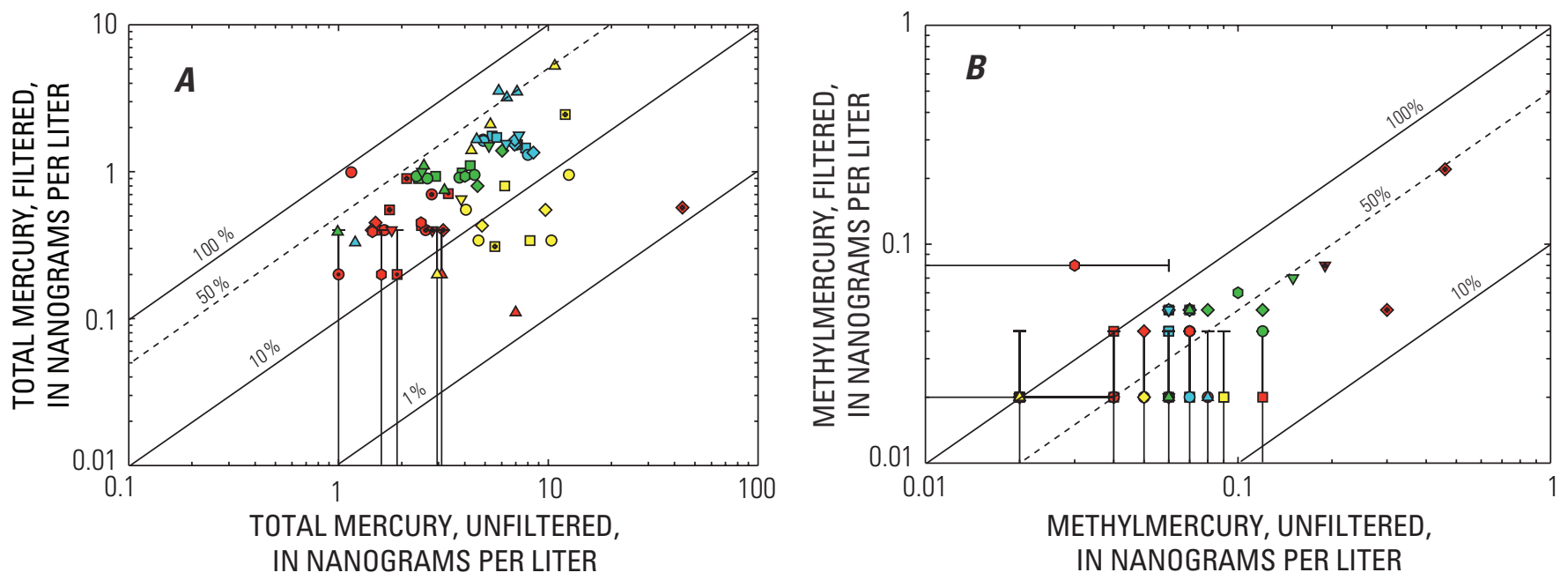

EXPLANATION

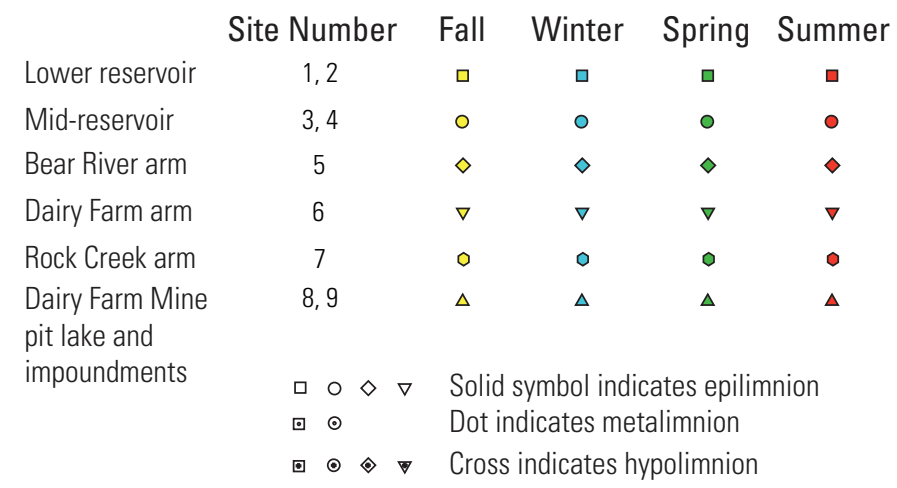

Figure 19. Relation between concentrations in unfiltered and filtered water samples from Camp Far West Reservoir, California, 2001-03: $(A)$ Total mercury, $(B)$ Methylmercury. Diagonal lines represent percentage passing through filter. In $(A)$, best values of total mercury used, as explained in text and in table 6. Error bars represent measurements less than method detection limit (MDL), with corresponding symbol plotted at 50 percent of MDL. 

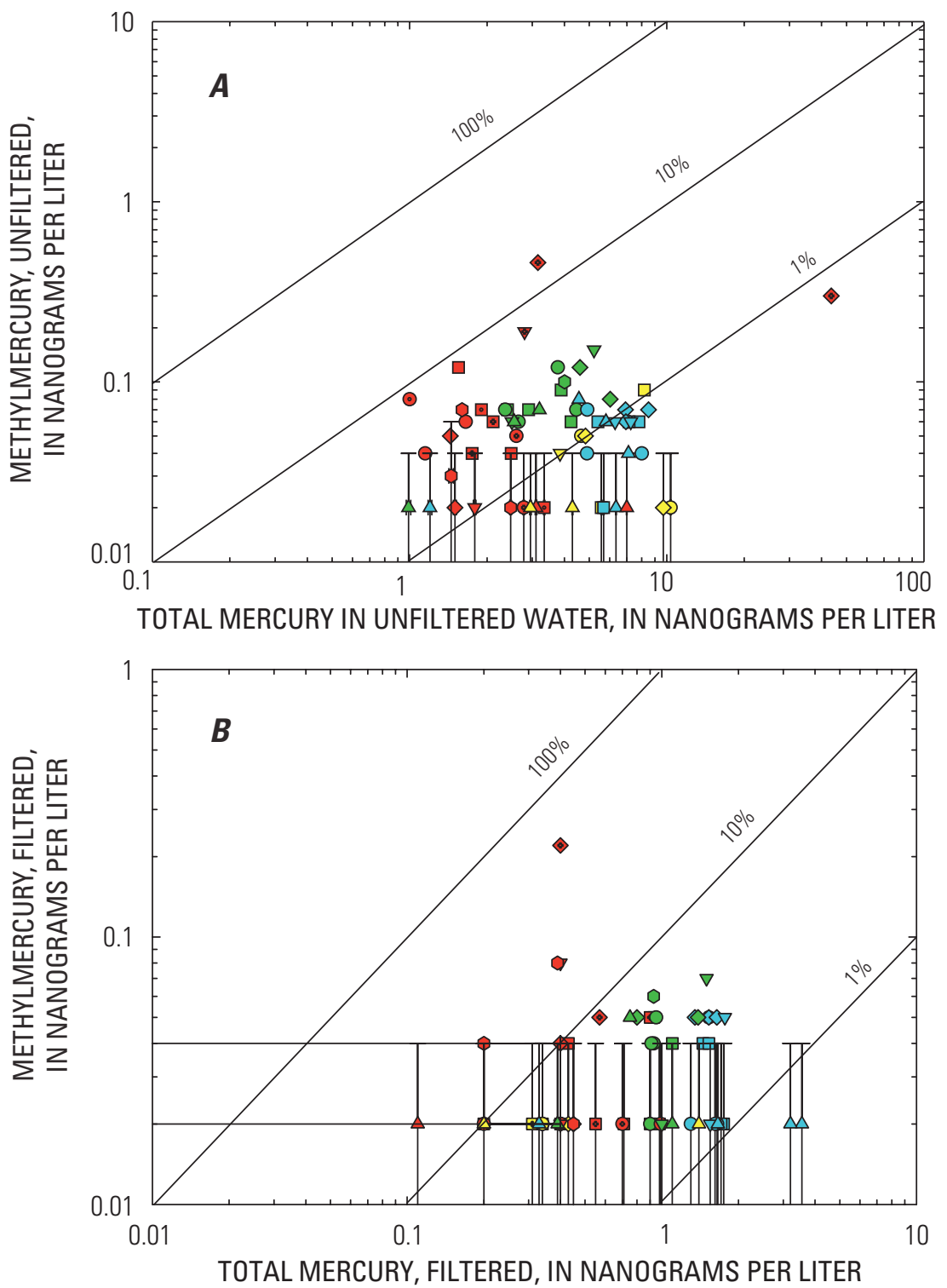

\section{EXPLANATION}

\begin{tabular}{|c|c|c|c|c|}
\hline & Fall & Winter & Spring & Summer \\
\hline Lower reservoir & $\square$ & $\square$ & $\square$ & $\square$ \\
\hline Mid-reservoir & o & o & o & ० \\
\hline Bear River arm & $\diamond$ & $\diamond$ & $\diamond$ & $\diamond$ \\
\hline Dairy Farm arm & $\nabla$ & $\nabla$ & $\nabla$ & $\nabla$ \\
\hline Rock Creek arm & 0 & 0 & 0 & 0 \\
\hline Dairy Farm Mine & $\Delta$ & $\Delta$ & $\Delta$ & $\Delta$ \\
\hline impoundments & $\begin{array}{ll}\square & 0 \\
\odot & \odot \\
\oplus & \oplus\end{array}$ & $\nabla$ & $\begin{array}{l}\text { Solid symbol } \\
\text { Dot indicates } \\
\text { Cross indicat }\end{array}$ & $\begin{array}{l}\text { indicates epilimnion } \\
\text { metalimnion } \\
\text { es hypolimnion }\end{array}$ \\
\hline
\end{tabular}

Figure 20. Relation between total mercury and methylmercury concentrations in water samples from Camp Far West Reservoir, California, 2001-03: $(A)$ Unfiltered water, $(B)$ Filtered water. Diagonal lines represent constant values of the ratio of methylmercury to total mercury, expressed as a percentages. Best values of total mercury used, as explained in text and in table 6. Error bars represent measurements less than method detection limit (MDL), with corresponding symbol plotted at 50 percent of MDL. 

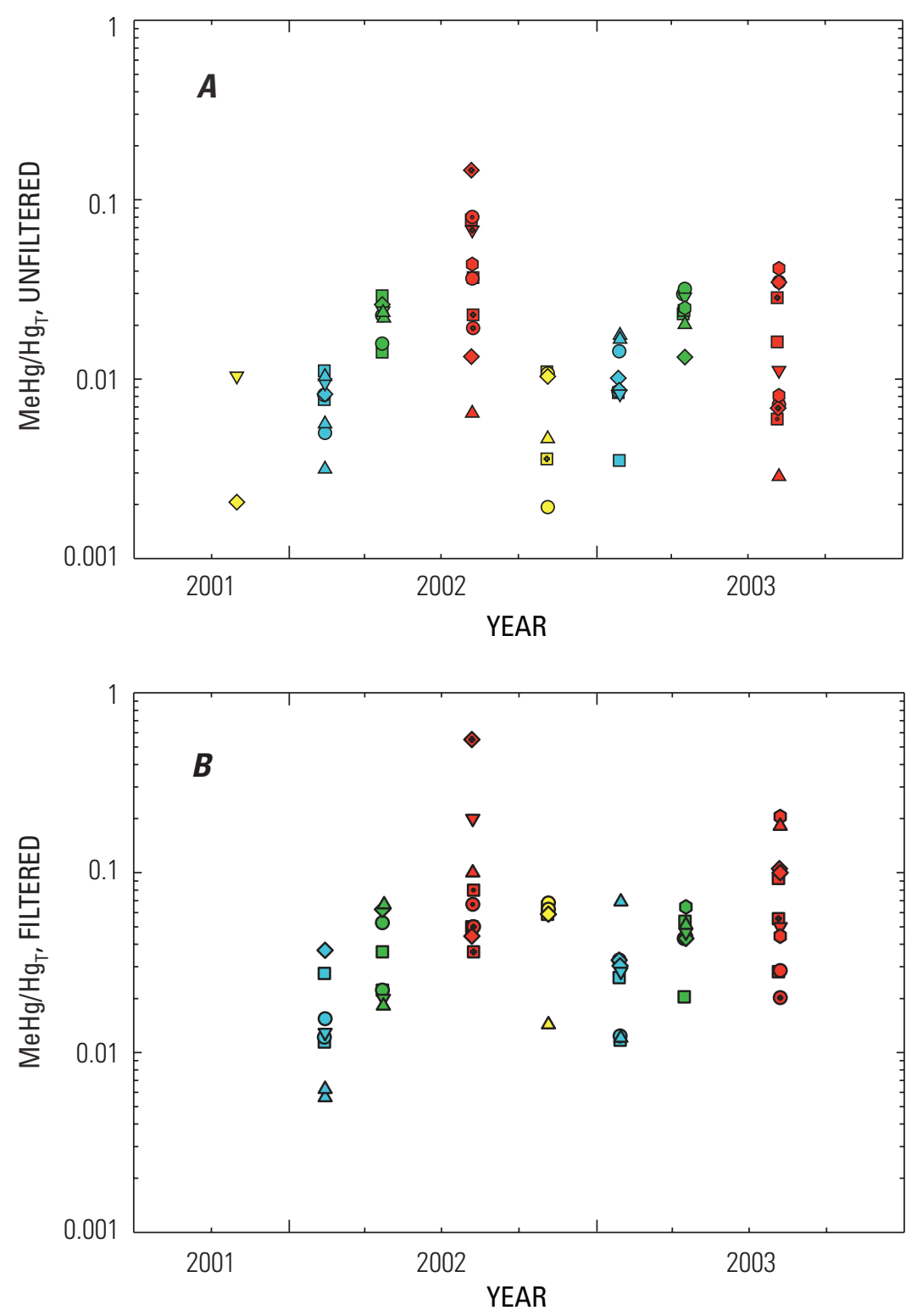

EXPLANATION

$\begin{array}{lcccc} & \text { Fall } & \text { Winter } & \text { Spring } & \text { Summer } \\ \text { Lower reservoir } & \square & \square & \square & \square \\ \text { Mid-reservoir } & \circ & \circ & \circ & \bullet \\ \text { Bear River arm } & \diamond & \diamond & \diamond & \diamond \\ \text { Dairy Farm arm } & \nabla & \nabla & \nabla & \nabla \\ \text { Rock Creek arm } & \diamond & \diamond & \bullet & \bullet \\ \begin{array}{l}\text { Dairy Farm Mine } \\ \text { pit lake and }\end{array} & \Delta & \Delta & \Delta & \Delta \\ \text { impoundments } & \square \circ \diamond \nabla & \text { Solid symbol indicates epilimnion } \\ & \square \odot & & \text { Dot indicates metalimnion } \\ & \square \odot \diamond \nabla & \text { Cross indicates hypolimnion }\end{array}$

Figure 21. Ratio of methylmercury to total mercury in water samples from Camp Far West Reservoir, California, 2001-03: $(A)$ Unfiltered water, $(B)$ Filtered water. $\mathrm{MeHg} / \mathrm{Hg}_{\mathrm{T}}$, ratio of methylmercury to total mercury 

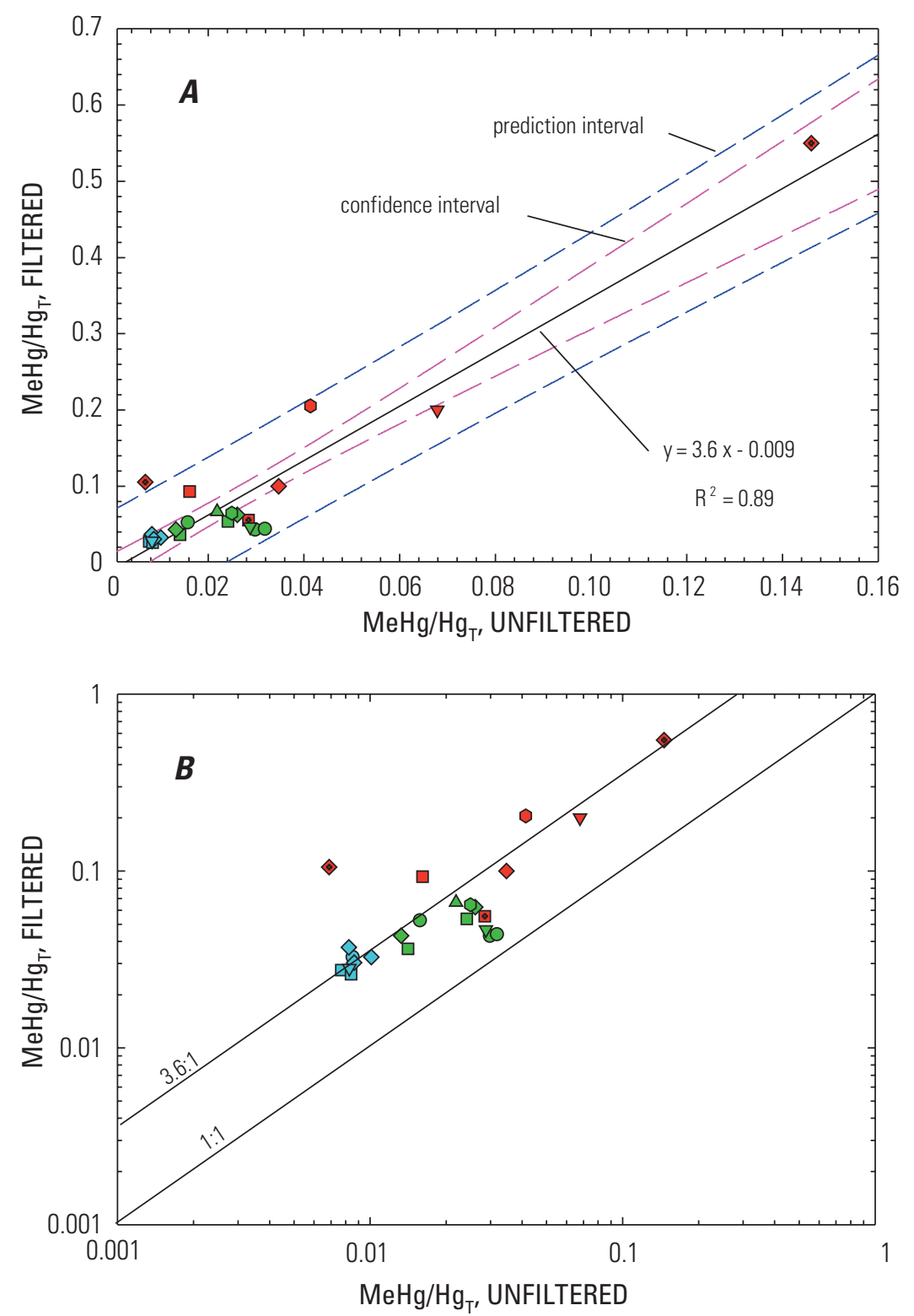

\section{EXPLANATION}

Fall Winter Spring Summer

\begin{tabular}{|c|c|c|c|c|}
\hline Lower reservoir & $\square$ & $\square$ & $\square$ & $\square$ \\
\hline Mid-reservoir & 0 & 0 & ० & 0 \\
\hline Bear River arm & $\diamond$ & $\diamond$ & $\diamond$ & $\diamond$ \\
\hline Dairy Farm arm & $\nabla$ & $\nabla$ & $\nabla$ & $\nabla$ \\
\hline Rock Creek arm & 0 & 0 & 0 & 0 \\
\hline $\begin{array}{l}\text { Dairy Farm Mine } \\
\text { pit lake and }\end{array}$ & $\Delta$ & $\Delta$ & $\Delta$ & $\Delta$ \\
\hline & $\begin{array}{l}\square \circ \diamond \\
\bullet \odot\end{array}$ & $\nabla$ & $\begin{array}{l}\text { Solid sym } \\
\text { Dot indica }\end{array}$ & $\begin{array}{l}\text { ates epilimnion } \\
\text { alimnion }\end{array}$ \\
\hline
\end{tabular}

Figure 22. Relation between ratio of methylmercury to total mercury in unfiltered and filtered water, Camp Far West Reservoir, California, 2001-03: (A) Linear plot indicating results of least-squares regression (B) Log-log plot showing regression line. Only detected values shown in plots and used in regression analysis. $\mathrm{MeHg} / \mathrm{Hg}_{\mathrm{T}^{\prime}}$ ratio of methylmercury to total mercury, $\mathrm{R}^{2}$, regression correlation coefficient. 


\section{Relations of Mercury and Methylmercury with Other Constituents}

\section{Dissolved Oxygen}

Several other studies have documented correlations between elevated methylmercury concentrations and low concentrations of dissolved oxygen (DO) in freshwater systems (for example, Regnell and others, 1996; K. Abu-Saba, Applied Marine Sciences, Inc., Santa Cruz, Calif., written commun., 2003; Kuwabara and others, 2005). Such a correlation is not surprising, given that anoxic conditions favor sulfate-reducing bacteria, which are thought to be largely responsible for $\mathrm{MeHg}$ formation (Compeau and Bartha, 1985; Gilmour and others, 1992). The relations between $\mathrm{DO}$ and $\mathrm{MeHg}$ in unfiltered and filtered water sampled from CFWR (figs. 23A-23B) are consistent with this hypothesis; the highest $\mathrm{MeHg}$ concentrations ( $>0.2 \mathrm{ng} / \mathrm{L}$ unfiltered and $>0.1 \mathrm{ng} / \mathrm{L}$ filtered) were found in water with the lowest concentrations of DO, typically less than $1 \mathrm{mg} / \mathrm{L}$ in the hypolimnion. However, these relations are far from systematic at higher values of DO. Both detected values and nondetects for $\mathrm{MeHg}$ (filtered and unfiltered) span the full range of DO concentration, which indicates that factors other than DO may be more important in controlling $\mathrm{MeHg}$ distribution within CFWR.

\section{Organic Carbon}

Plots showing the relations between dissolved organic carbon (DOC) and $\mathrm{Hg}_{\mathrm{T}}$ in unfiltered water (fig. 24A) and filtered water (fig. 24B) indicate no apparent correlations; DOC concentrations do not vary seasonally to the same extent as $\mathrm{Hg}_{\mathrm{T}}$ concentrations. A plot showing the relation between particulate $\mathrm{Hg}_{\mathrm{T}}$ and particulate organic carbon (POC; fig. 24C) also indicates little to no correlation.

The relations between DOC and MeHg in unfiltered water (fig. 24D) and filtered water (fig. 24E) also show no apparent correlations. These results are in contrast to other systems, such as freshwaters in Minnesota, Michigan, and Wisconsin, where a strong association was found between $\mathrm{MeHg}$ and filterable organic carbon (Babiarz and others, 2001). A plot of the relation between POC and particulate MeHg (fig. 24F) shows a single, summer hypolimnion sample from the Bear River Arm containing elevated concentrations of both constituents, but no apparent correlation among the other samples.

\section{Suspended Solids}

The relation between concentrations of suspended solids and trace elements in unfiltered water samples can be useful for evaluating the apparent concentration of the trace elements on the suspended material. For $\mathrm{Hg}_{\mathrm{T}}$, a set of four plots illustrates different ways of evaluating apparent $\mathrm{Hg}_{\mathrm{T}}$ concentration in suspended particles. On the plot of unfiltered $\mathrm{Hg}_{\mathrm{T}}$ concentration and total suspended solids (fig. 25A), diagonal contour lines of constant concentration of $\mathrm{Hg}_{\mathrm{T}}$ in the suspended solids are shown. During spring and fall, apparent $\mathrm{Hg}_{\mathrm{T}}$ concentrations for most stations are between 0.4 and $1.0 \mu \mathrm{g} / \mathrm{g}$ (equivalent to part per million, or ppm). This range of concentrations is similar to that observed for the top $4 \mathrm{~cm}$ of bed sediment, sampled at six locations on six occasions between fall 2001 and winter 2003. The apparent $\mathrm{Hg}_{\mathrm{T}}$ concentrations in suspended solids during winter are considerably higher, with most of the samples indicating values greater than $1.0 \mathrm{ppm}$. In contrast, most of the data for summer samples indicate apparent $\mathrm{Hg}_{\mathrm{T}}$ concentrations in suspended solids less than $0.4 \mathrm{ppm}$, with some samples less than $0.1 \mathrm{ppm}$. The winter and summer data are anomalous, and warrant further investigation. (Some possible explanations for these observations are offered in the Discussion section of this report.) A similar plot (fig. 25B) using suspended silt and clay (material passing through a 63 micrometer sieve) gives results similar to those of the plot for total suspended solids.

Using unfiltered water samples for plots such as figures $25 A-25 B$ can lead to misleading conclusions because material passing though the filter is considered part of the suspended material and is counted toward the apparent concentration in the suspended solids. To the extent that the material passing through the filter is colloidal (very fine particulate material), this leads to a consistent interpretation. However, another approach is to consider the particulate concentration, operationally defined as the material that does not pass through a filter of a certain pore diameter. For this study, we have used pore diameters of 0.45 and 0.7 micrometer, so the particulate concentrations of $\mathrm{Hg}_{\mathrm{T}}$ and $\mathrm{MeHg}$ are defined as relating to particles that did not pass through these filters. Plots of particulate $\mathrm{Hg}_{\mathrm{T}}$ versus total suspended solids (fig. 25C) or versus suspended silt and clay (fig. 25D) indicate similar apparent concentrations and a similar seasonal pattern. Using particulate concentrations instead of unfiltered ones reduces the concentration by the filtered amount, which shifts the points to the right on the diagrams and results in lower apparent concentrations of $\mathrm{Hg}_{\mathrm{T}}$ in the suspended solids. The shift tends to be greater (on a logarithmic scale) for data with lower $\mathrm{Hg}_{\mathrm{T}}$ concentrations.

A similar analysis of apparent MeHg concentrations in suspended solids is presented in figures 26A-26D. Using MeHg concentrations in unfiltered water samples, apparent MeHg concentrations in suspended solids ranged from about 2 to $100 \mathrm{ppb}$ for samples in which MeHg was detected (figs. 26A-26B). Maximum apparent suspendedsolid-MeHg concentrations for most non-detects ranged from about 1 to $10 \mathrm{ppb}$. When particulate MeHg concentrations are used (figs. 26C-26D), apparent suspended-solid-MeHg concentrations are considerably lower for most samples, although a small number of the winter and summer samples exceed $10 \mathrm{ppb}$. 

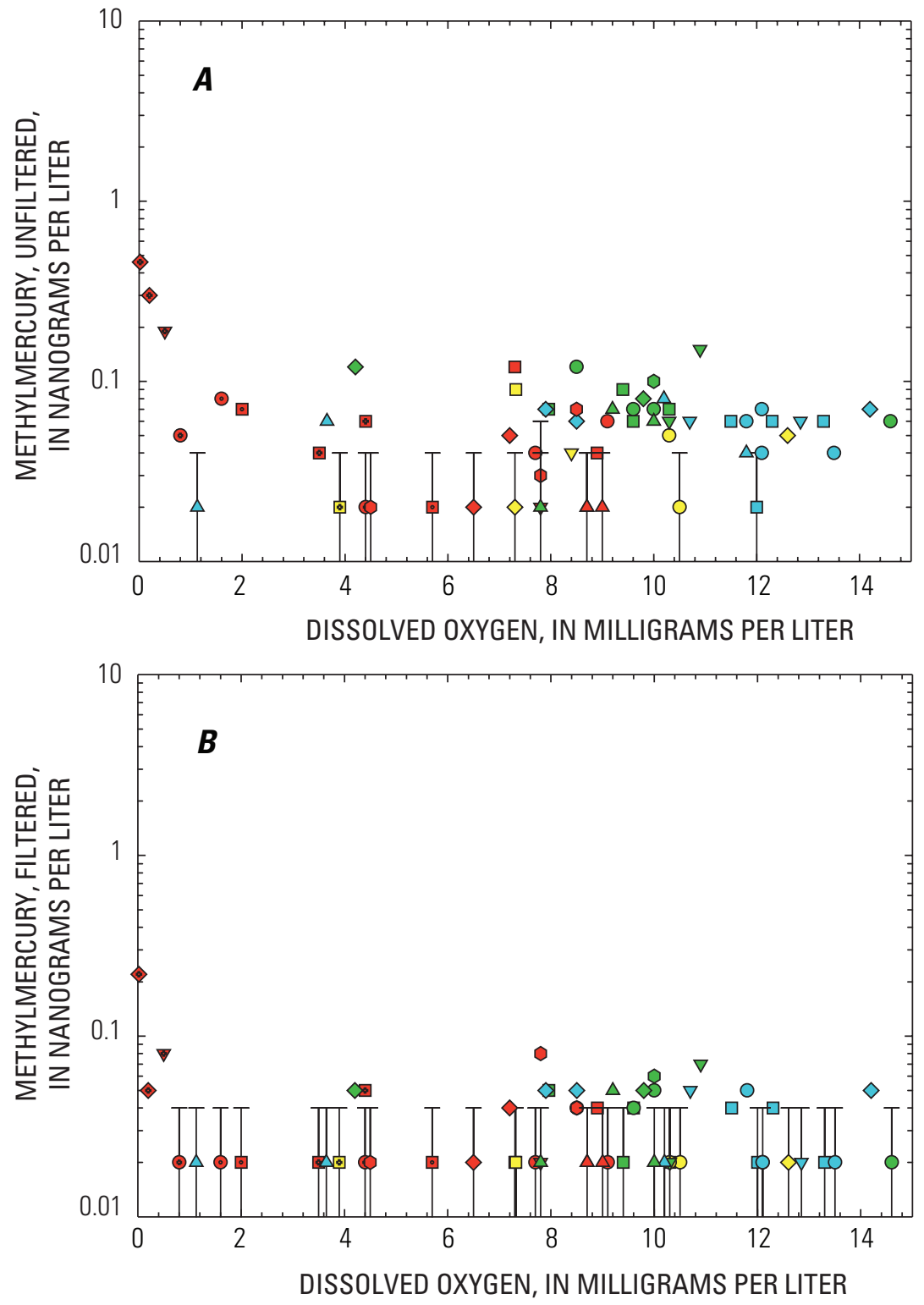

\begin{tabular}{lcccc} 
& \multicolumn{4}{c}{ EXPLANATION } \\
& Fall & Winter & Spring & Summer \\
Lower reservoir & $\square$ & $\square$ & $\square$ & $\square$ \\
Mid-reservoir & $\circ$ & $\circ$ & $\circ$ & $\circ$ \\
Bear River arm & $\diamond$ & $\diamond$ & $\diamond$ & $\diamond$ \\
Dairy Farm arm & $\nabla$ & $\nabla$ & $\nabla$ & $\nabla$ \\
Rock Creek arm & $\bullet$ & $\bullet$ & $\bullet$ & $\bullet$ \\
Dairy Farm Mine & $\Delta$ & $\Delta$ & $\Delta$ & $\Delta$ \\
pit lake and & & & & \\
impoundments & $\square \circ \diamond \nabla$ & Solid symbol indicates epilimnion \\
& $\square \odot$ & & Dot indicates metalimnion \\
& $\square \odot \diamond \nabla$ & Cross indicates hypolimnion
\end{tabular}

Figure 23. Relations between concentrations of methylmercury and dissolved oxygen in Camp Far West Reservoir, California, 2001-03: $(A)$ unfiltered methylmercury, $(B)$ filtered methylmercury. Error bars represent measurements less than method detection limit (MDL), with corresponding symbol plotted at 50 percent of MDL. 
Environmental Factors Affecting Mercury in Camp Far West Reservoir, California, 2001-03
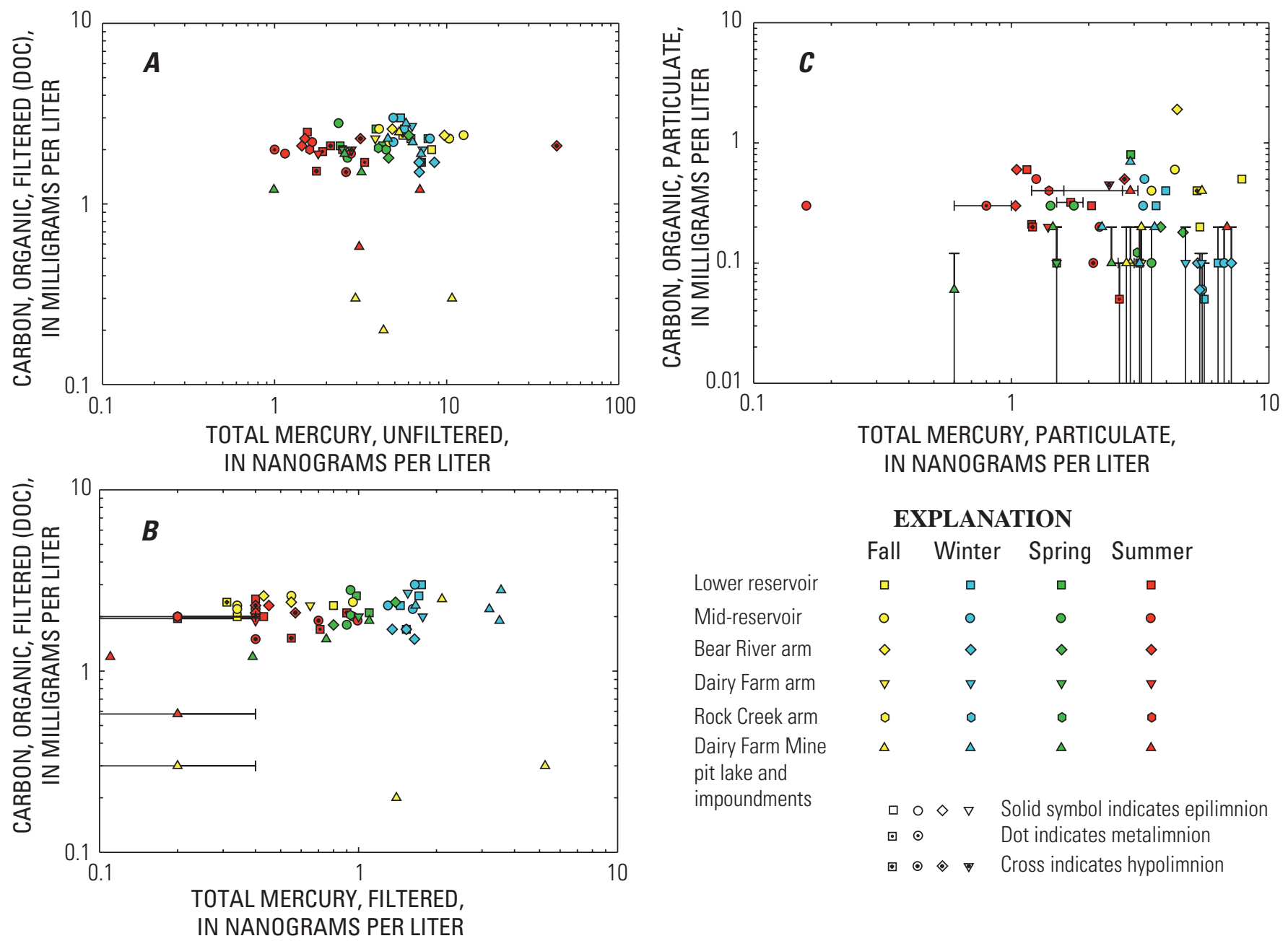

\begin{tabular}{|c|c|c|c|c|}
\hline \multicolumn{5}{|c|}{ EXPLANATION } \\
\hline & Fall & Winter & Spring & Summer \\
\hline Lower reservoir & $\square$ & $\square$ & $\square$ & $\square$ \\
\hline Mid-reservoir & $\circ$ & $\circ$ & $\circ$ & ○ \\
\hline Bear River arm & $\diamond$ & $\diamond$ & $\diamond$ & $\diamond$ \\
\hline Dairy Farm arm & $\nabla$ & $\nabla$ & $\nabla$ & $\nabla$ \\
\hline Rock Creek arm & 0 & 0 & - & - \\
\hline $\begin{array}{l}\text { Dairy Farm Mine } \\
\text { pit lake and }\end{array}$ & $\Delta$ & $\Delta$ & $\Delta$ & $\Delta$ \\
\hline impoundments & $\begin{array}{l}\square \\
\square\end{array}$ & $\diamond \nabla$ & $\begin{array}{l}\text { Solid symbo } \\
\text { Dot indicate }\end{array}$ & $\begin{array}{l}\text { indicates epilimnion } \\
\text { s metalimnion }\end{array}$ \\
\hline
\end{tabular}

Figure 24. Relations between concentrations of mercury and carbon species in water samples from Camp Far West Reservoir, California, 2001-03: (A) Unfiltered total mercury and dissolved organic carbon (DOC),

$(B)$ Filtered total mercury and dissolved organic carbon, $(C)$ Particulate total mercury and particulate organic carbon, $(D)$ Unfiltered methylmercury and dissolved organic carbon, $(E)$ Filtered methylmercury and dissolved organic carbon, $(F)$ Particulate methylmercury and particulate organic carbon. In $(A),(B)$, and $(C)$ best values of total mercury used, as explained in text and in table 6 . Error bars represent measurements less than method detection limit (MDL), with corresponding symbol plotted at 50 percent of MDL. 

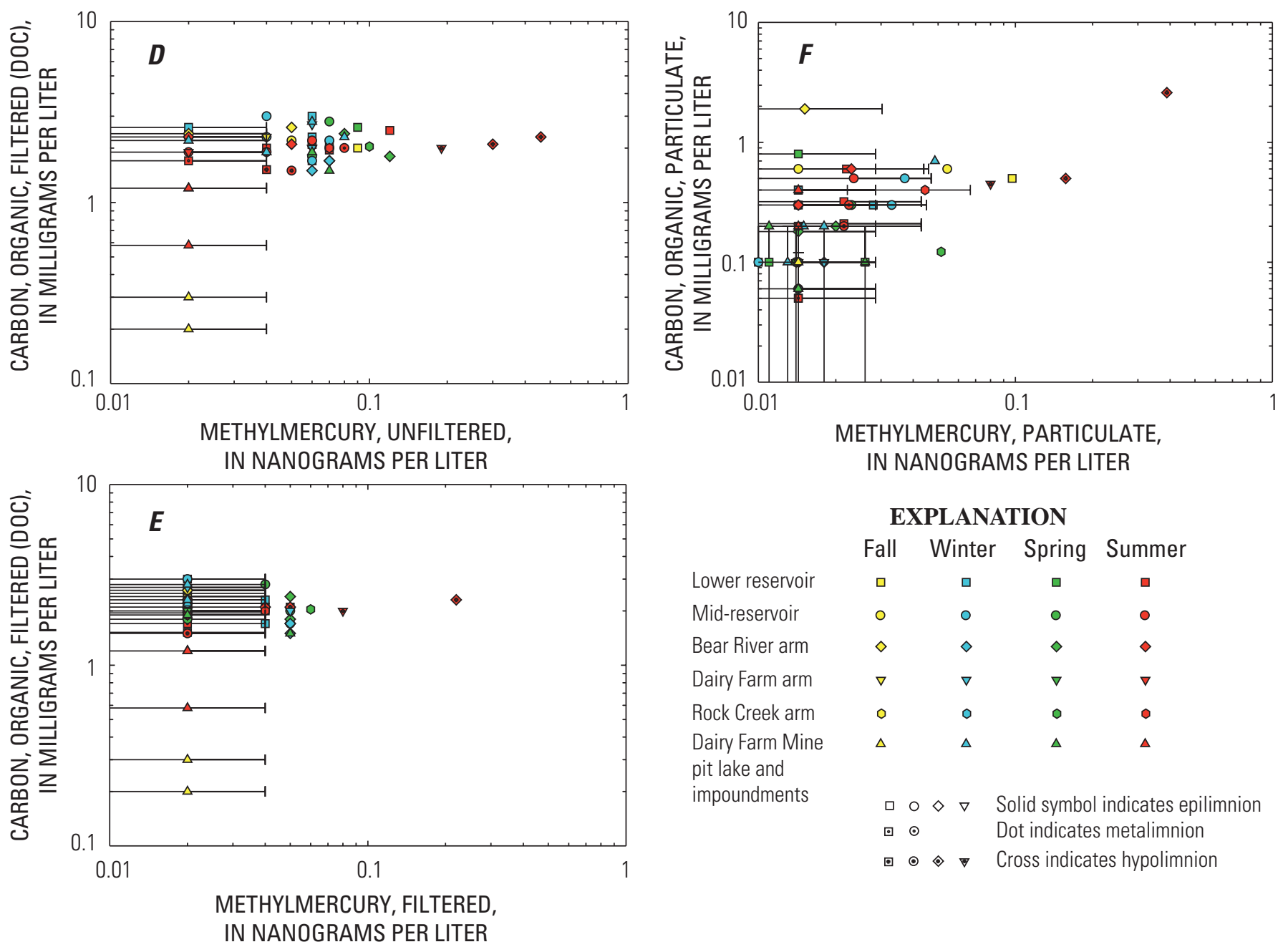

IN NANOGRAMS PER LITER

\section{EXPLANATION}

Lower reservoir $\quad$ 口 $\quad$ 口 $\quad$ 口

Mid-reservoir $\circ \quad \circ \quad \circ \quad \circ$

Bear River arm $\diamond \diamond \diamond \diamond$

$\begin{array}{lllllll}\text { Dairy Farm arm } & \nabla & \nabla & \nabla & \nabla\end{array}$

Rock Creek arm $\quad 0 \quad 0 \quad 0 \quad$

Dairy Farm Mine $\quad \Delta \quad \Delta \quad \Delta \quad \Delta \quad \Delta$

pit lake and

impoundments

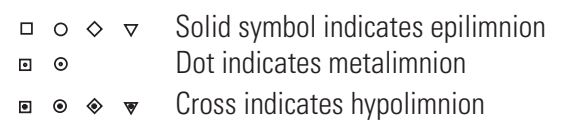

Figure 24. Continued. 

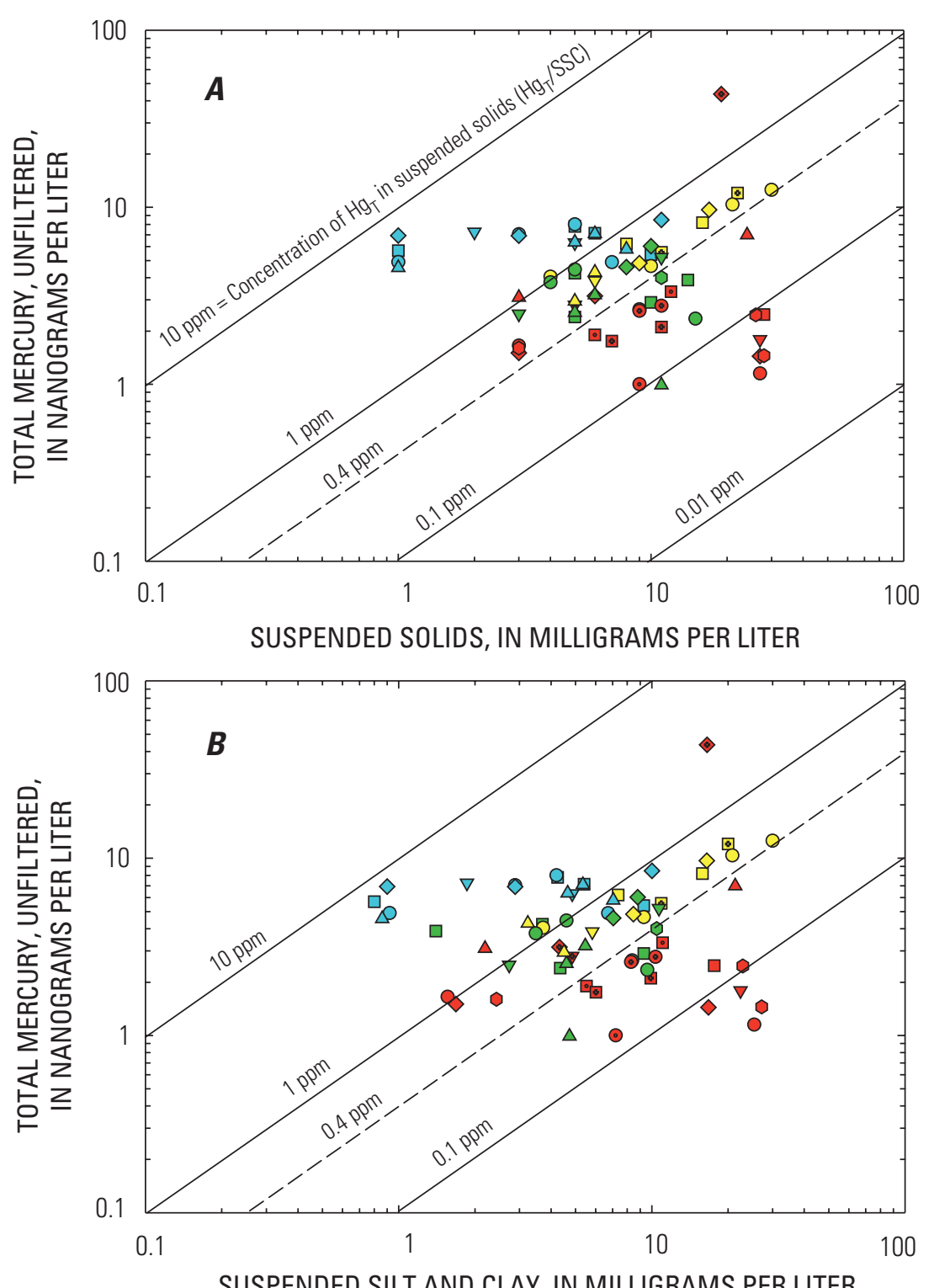

SUSPENDED SILT AND CLAY, IN MILLIGRAMS PER LITER

EXPLANATION

Fall Winter Spring Summer

$\begin{array}{llccc}\text { Lower reservoir } & \square & \square & \square & \square \\ \text { Mid-reservoir } & \circ & \circ & \circ & \circ \\ \text { Bear River arm } & \diamond & \diamond & \diamond & \diamond \\ \text { Dairy Farm arm } & \nabla & \nabla & \nabla & \nabla \\ \text { Rock Creek arm } & \diamond & \diamond & \bullet & \bullet \\ \begin{array}{l}\text { Dairy Farm Mine } \\ \text { pit lake and }\end{array} & \Delta & \Delta & \Delta & \Delta \\ \text { impoundments } & \square \circ \diamond \nabla & \text { Solid symbol indicates epilimnion } \\ & \square \odot & \text { Dot indicates metalimnion } \\ & \square \odot \diamond \nabla & \text { Cross indicates hypolimnion }\end{array}$

Figure 25. Relations between concentrations of total mercury and suspended solids in water samples from Camp Far West Reservoir, California, 2001-03: (A) Unfiltered total mercury $\left(\mathrm{Hg}_{\mathrm{T}}\right)$ and total suspended solids, $(B)$ Unfiltered total mercury and suspended silt plus clay, $(C)$ Particulate total mercury and total suspended solids, $(D)$ Particulate total mercury and suspended silt plus clay. Diagonal lines represent contours of the ratio of total mercury to suspended solids, which is equal to the apparent concentration of total mercury in the suspended solids, in ppm (parts per million), equivalent to micrograms per gram. Best values of total mercury used, as explained in text and in table 6. Concentrations of silt plus clay in $(B)$ and $(D)$ calculated from suspended solids concentration (SSC) and percentage of material passing through 0.063 micrometer screen, as described in text and in table 2. 

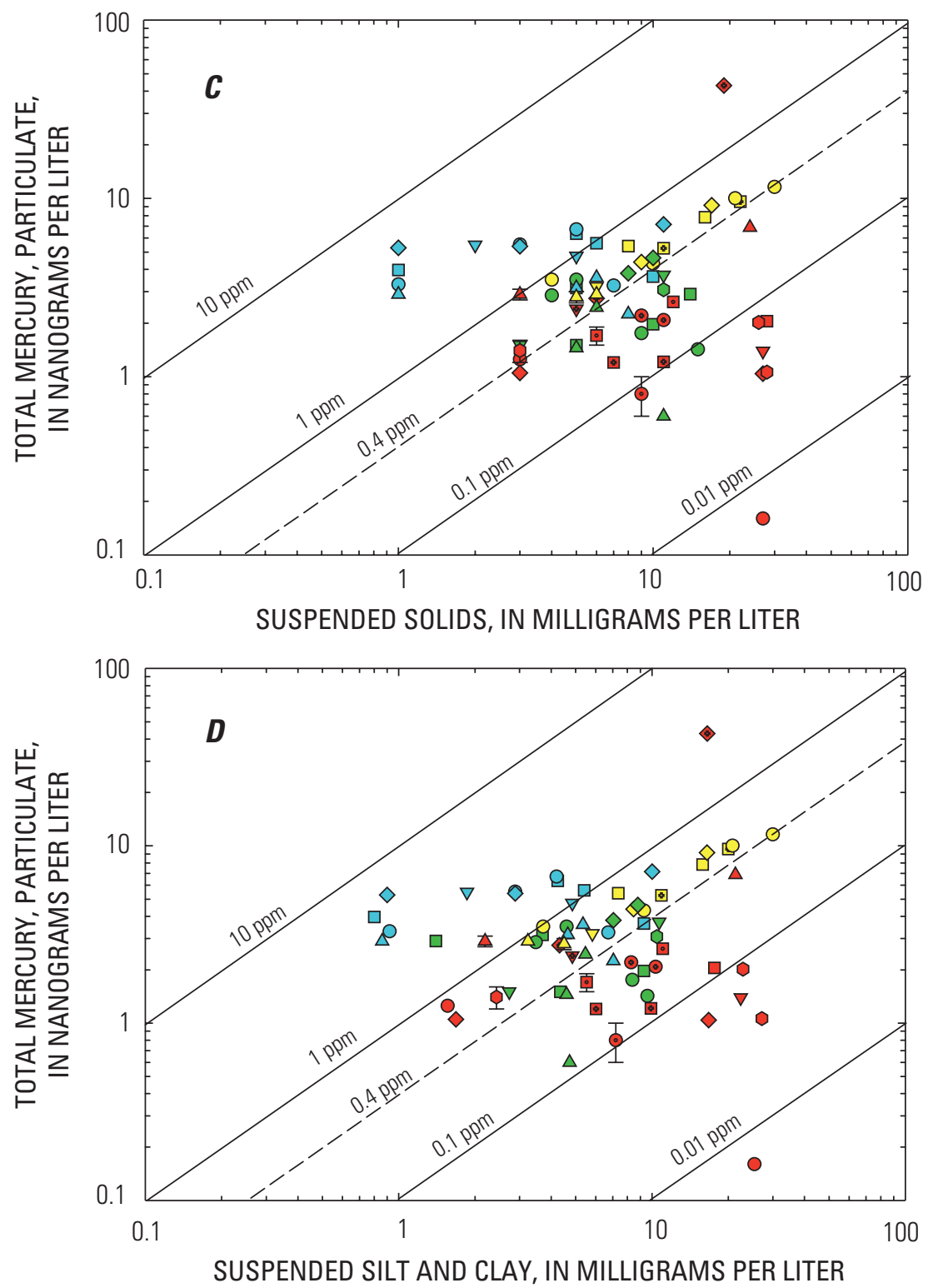

EXPLANATION

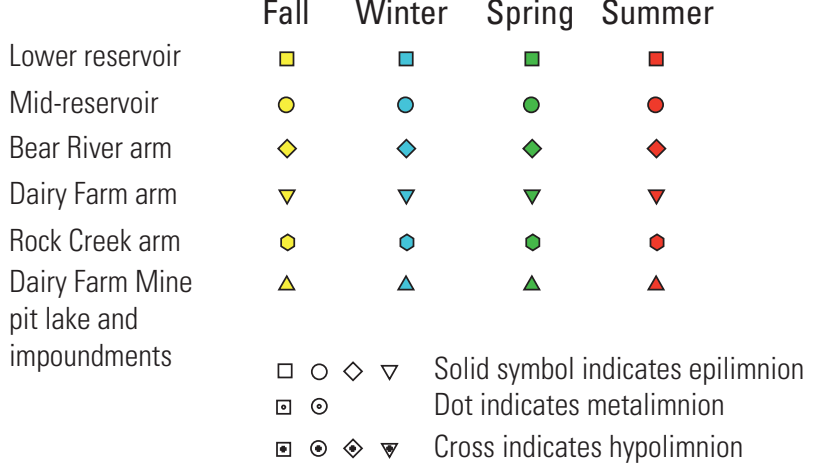

Figure 25. Continued. 

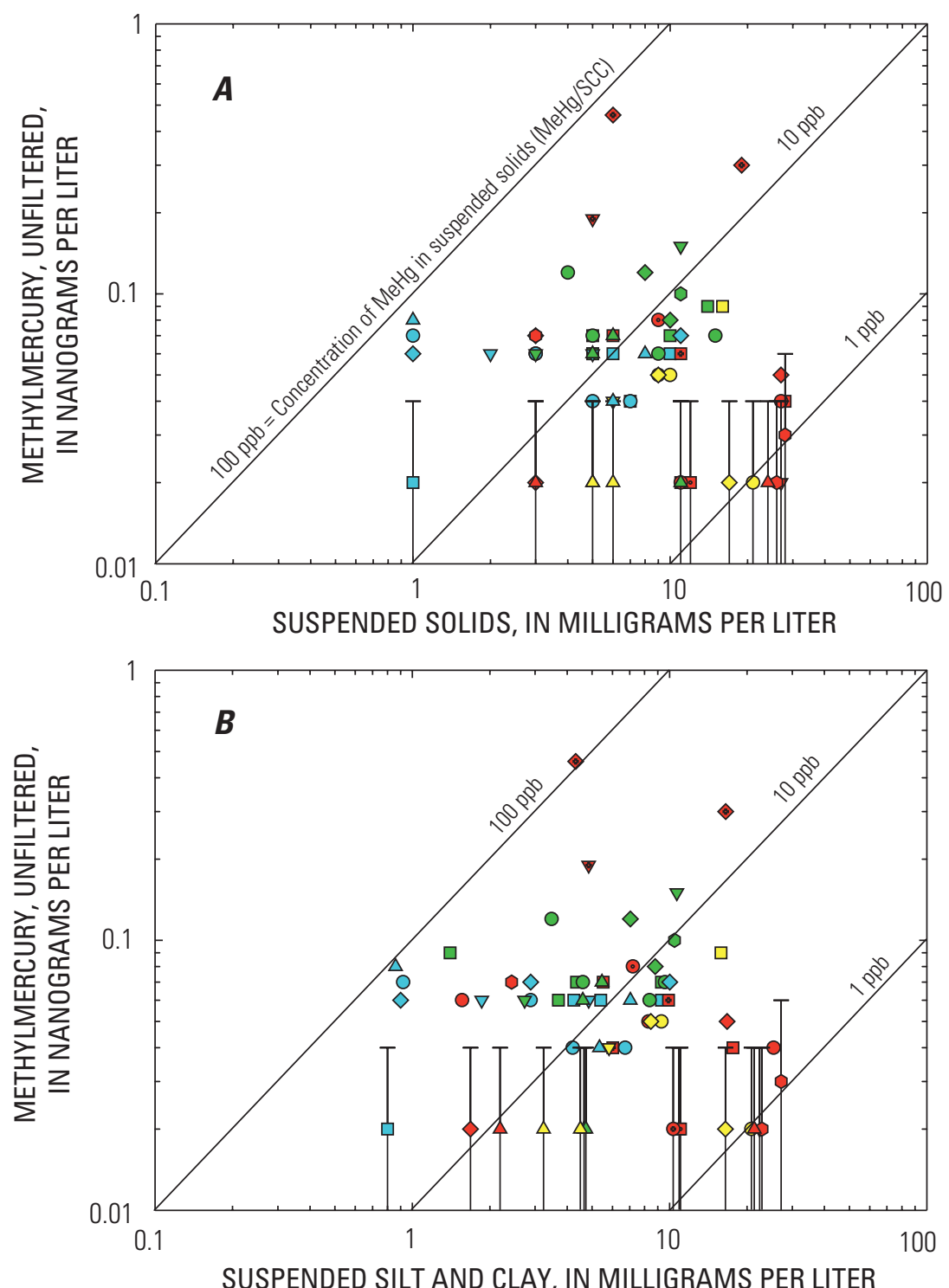

SUSPENDED SILT AND CLAY, IN MILLIGRAMS PER LITER

EXPLANATION

Lower reservoir

Mid-reservoir

Bear River arm

Dairy Farm arm

Rock Creek arm

Dairy Farm Mine

pit lake and

impoundments

\section{Fall Winter Spring Summer}

$\begin{array}{cccc}\square & \square & \square & \square \\ \circ & 0 & 0 & 0 \\ \diamond & \diamond & \diamond & \diamond \\ \nabla & \nabla & \nabla & \nabla \\ 0 & 0 & 0 & 0 \\ \Delta & \Delta & \Delta & \Delta\end{array}$

\footnotetext{
$\square \diamond \diamond \quad$ Solid symbol indicates epilimnion $\odot \odot \quad$ Dot indicates metalimnion

$\bullet \odot \diamond$ Cross indicates hypolimnion
}

Figure 26. Relations between concentrations of methylmercury and suspended solids in water samples from Camp Far West Reservoir, California, 2001-03: (A) Unfiltered methylmercury and suspended solids, $(B)$ Unfiltered methylmercury and suspended silt plus clay, (C) Particulate methylmercury and suspended solids, (D) Particulate methylmercury and suspended silt plus clay. Diagonal lines represent contours of the ratio of methylmercury to suspended solids, which is equal to the apparent concentration of methylmercury in the suspended solids, in $\mathrm{ppb}$ (parts per billion) equivalent to nanograms per gram. Concentrations of silt plus clay in $(B)$ and $(D)$ calculated from suspended solids concentration and percentage of material passing through 0.063 micrometer screen, as described in text and in table 2. Error bars represent measurements less than method detection limit (MDL), with corresponding symbol plotted at 50 percent of MDL. 

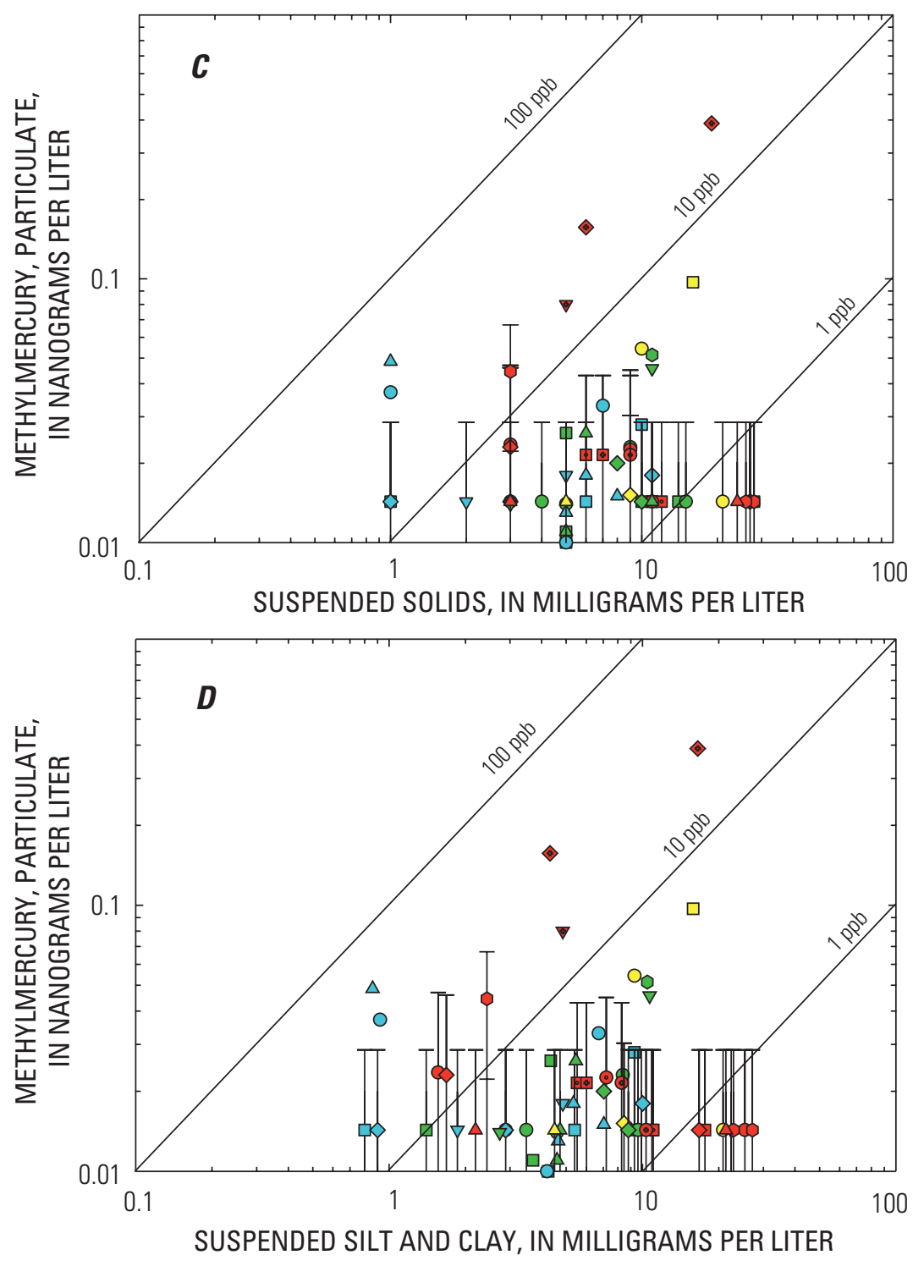

\section{EXPLANATION}

\begin{tabular}{|c|c|c|c|c|}
\hline Lower reservoir & $\begin{array}{c}\text { rall } \\
\text { 口 }\end{array}$ & $\begin{array}{c}\text { Winter } \\
\square\end{array}$ & Sprıng & Summer \\
\hline Mid-reservoir & o & 0 & o & o \\
\hline Bear River arm & $\diamond$ & $\diamond$ & $\diamond$ & $\diamond$ \\
\hline Dairy Farm arm & $\nabla$ & $\nabla$ & $\nabla$ & $\nabla$ \\
\hline Rock Creek arm & 0 & 0 & 0 & 0 \\
\hline $\begin{array}{l}\text { Dairy Farm Mine } \\
\text { pit lake and }\end{array}$ & $\Delta$ & $\Delta$ & $\Delta$ & $\Delta$ \\
\hline impoundments & $\begin{array}{l}\square \circ \\
\square \odot\end{array}$ & & $\begin{array}{l}\text { Solid symbe } \\
\text { Dot indicate } \\
\text { Crossindica }\end{array}$ & $\begin{array}{l}\text { dicates epilimnion } \\
\text { netalimnion } \\
\text { hypolimnion }\end{array}$ \\
\hline
\end{tabular}

Figure 26. Continued. 


\section{Nutrients}

The relations between concentrations of total phosphorus $(\mathrm{P})$, total mercury $\left(\mathrm{Hg}_{\mathrm{T}}\right)$, and methylmercury $(\mathrm{MeHg})$ provide some insights into possible links between the cycling of mercury and nutrients within CFWR. In unfiltered water, $\mathrm{Hg}_{\mathrm{T}}$ and $\mathrm{P}$ appear to have a positive correlation (fig. 27A), which is not surprising because these constituents followed similar seasonal trends (figs. $18 \mathrm{~A}$ and $\underline{13 \mathrm{~A}}$, respectively). Most of the summer samples were low in both $\mathrm{Hg}_{\mathrm{T}}$ and $\mathrm{P}$, with the notable exception of a hypolimnion sample from the BRA station (site 5). Most fall samples were relatively elevated in both $\mathrm{Hg}_{\mathrm{T}}$ and $\mathrm{P}$ concentrations, whereas winter and spring samples had intermediate $\mathrm{Hg}_{\mathrm{T}}$ and $\mathrm{P}$ concentrations. A linear least-squares regression of the log-transformed data in figure 27A, from sites 1-7 (excluding the DFP and DFI stations [fig. 5]), has an $\mathrm{R}^{2}$ value of 0.48 . A plot of the relation between particulate $\mathrm{Hg}_{\mathrm{T}}$ and particulate total $\mathrm{P}$ (fig. 27B ) shows a similar trend to the unfiltered data, On a plot of total $\mathrm{P}$ and $\mathrm{MeHg}$ concentrations in unfiltered water (fig. 27C), a seasonal pattern can also be identified. Starting with intermediate $P$ concentrations in the winter and spring, there is a general decline in $\mathrm{P}$ into the summer with the exception of two hypolimnion samples from the BRA station with relatively high concentrations of both total P and MeHg. The fall samples had lower concentrations of MeHg but were still relatively high in total P. A plot of particulate MeHg and particulate total P (fig. 27D) shows a better correlation than that for the analogous unfiltered data (fig. 27C).

The relations between ammonia plus organic nitrogen ( $\mathrm{NH}_{3}+\mathrm{N}$-org), $\mathrm{Hg}_{\mathrm{T}}$, and $\mathrm{MeHg}$ also show systematic seasonal patterns. For most unfiltered samples, there is a general decline in both $\mathrm{Hg}_{\mathrm{T}}$ and $\mathrm{NH}_{3}+\mathrm{N}$-org from fall and winter to spring, and then $\mathrm{Hg}_{\mathrm{T}}$ declines further to summer as the range in $\mathrm{NH}_{3}+\mathrm{N}$-org remains about the same in spring and summer (fig. 28A). A similar seasonal pattern is evident for $\mathrm{Hg}_{\mathrm{T}}$ and $\mathrm{NH}_{3}+\mathrm{N}$-org concentrations in filtered water samples (fig. 28B); a systematic decline in $\mathrm{Hg}_{\mathrm{T}}$ was observed from winter to spring to summer with $\mathrm{NH}_{3}+\mathrm{N}$-org concentrations in a fairly narrow range $(0.06$ to $0.2 \mathrm{mg} / \mathrm{L}$ ), then in the fall the $\mathrm{NH}_{3}+\mathrm{N}$-org concentrations increased at most stations $(0.15$ to $0.3 \mathrm{mg} / \mathrm{L}$ ) and especially at the DFP and DFI stations ( 1 to $3 \mathrm{mg} / \mathrm{L}$ ). The relation between particulate $\mathrm{Hg}_{\mathrm{T}}$ and particulate $\mathrm{NH}_{3}+\mathrm{N}$-org (fig. 28C) shows some seasonal variation but overall there is no apparent correlation. The relation between MeHg and $\mathrm{NH}_{3}+\mathrm{N}$-org in unfiltered water (fig. 28D) is similar to that observed between for total $\mathrm{P}$ and $\mathrm{MeHg}$ (fig. 27C) in unfiltered water.

\section{Sulfur Isotopes}

Concentrations of $\mathrm{Hg}_{\mathrm{T}}$ in both unfiltered and filtered water show systematic decline from fall to winter to spring to summer (figs. 18A-18B), a pattern that is somewhat similar to the seasonal shift in sulfur isotopes of aqueous sulfate (fig. 11B). Plots showing the relations between sulfur isotopes in aqueous sulfate and $\mathrm{Hg}_{\mathrm{T}}$ concentrations in unfiltered water (fig. 29A) and filtered water (fig. 29B) are useful in terms of understanding seasonal variations. The fall is characterized by large values of $\delta^{34} \mathrm{~S}_{\mathrm{SO} 4}$, elevated concentrations of $\mathrm{Hg}_{\mathrm{T}}$ in unfiltered water, and relatively low concentrations of $\mathrm{Hg}_{\mathrm{T}}$ in filtered water at most sampling sites. Concentrations of $\mathrm{Hg}_{\mathrm{T}}$ in both filtered and unfiltered water generally decrease during from winter to spring and from spring to summer, and the values of $\delta^{34} \mathrm{~S}_{\mathrm{SO} 4}$ also decrease slightly during this period. The increase of $\delta^{34} \mathrm{~S}_{\mathrm{SO} 4}$ between summer and fall corresponds to an increase in $\mathrm{Hg}_{\mathrm{T}}$ concentration in filtered water. On the basis of correlations of $\delta^{34} \mathrm{~S}_{\mathrm{SO} 4}$ with concentrations of sulfate and calcium (figs. 12B-12C), and correlations among sulfate, calcium, and other major cations and anions (fig. 9), the principal source of aqueous sulfate causing the fall increase in $\delta^{34} \mathrm{~S}_{\mathrm{SO} 4}$ appears to be the Bear River input to CFWR. The correlation between $\delta^{34} \mathrm{~S}_{\mathrm{SO} 4}$ and $\mathrm{Hg}_{\mathrm{T}}$ in unfiltered water (fig. 29A) may indicate that the principal source of the increased $\mathrm{Hg}_{\mathrm{T}}$ concentration is also the Bear River input.

Mercury and sulfur cycling are linked by the role that sulfate-reducing bacteria play in methylating mercury, a process that likely takes place in shallow sediments and possibly also in anoxic parts of the water column. It is possible that hydrogen sulfide produced by sulfate-reducing bacteria combines with available inorganic mercury to make mercury sulfide, a relatively insoluble precipitate that would effectively scavenge dissolved mercury from the water column, explaining the relatively low concentrations of $\mathrm{Hg}_{\mathrm{T}}$ in filtered water in the summer and fall when this process appears to be most active. Microbially mediated sulfate reduction tends to cause a shift to larger values of $\delta^{34} \mathrm{~S}_{\text {SO4 }}$ because the microbes preferentially reduce ${ }^{32} \mathrm{~S}$ rather than ${ }^{34} \mathrm{~S}$ (Seal and others, 2000). The shift to larger values of $\delta^{34} \mathrm{~S}_{\mathrm{SO} 4}$ in the CFWR water column in the fall may be partly influenced by this process; however, such effects are expected to be confined to the hypolimnion prior to destratification. Because the fall samples were taken before destratification (figs. $6, \underline{7 A-7 B}$ ) and the shift in $\delta^{34} S_{\text {sO4 }}$ values is seen in both hypolimnion and epilimnion samples throughout the reservoir, it is unlikely that microbial sulfate reduction within CFWR is the principal cause of the S-isotope shift. Nevertheless, microbial sulfate reduction and its seasonality within CFWR sediments play an important role in $\mathrm{Hg}$ methylation. However, the seasonal changes in $\delta^{34} \mathrm{~S}_{\mathrm{SO} 4}$ of Bear River input water coupled with the extreme drawdown of CFWR during fall confounds the use of sulfur isotopes to track sulfate reduction processes in the reservoir. 

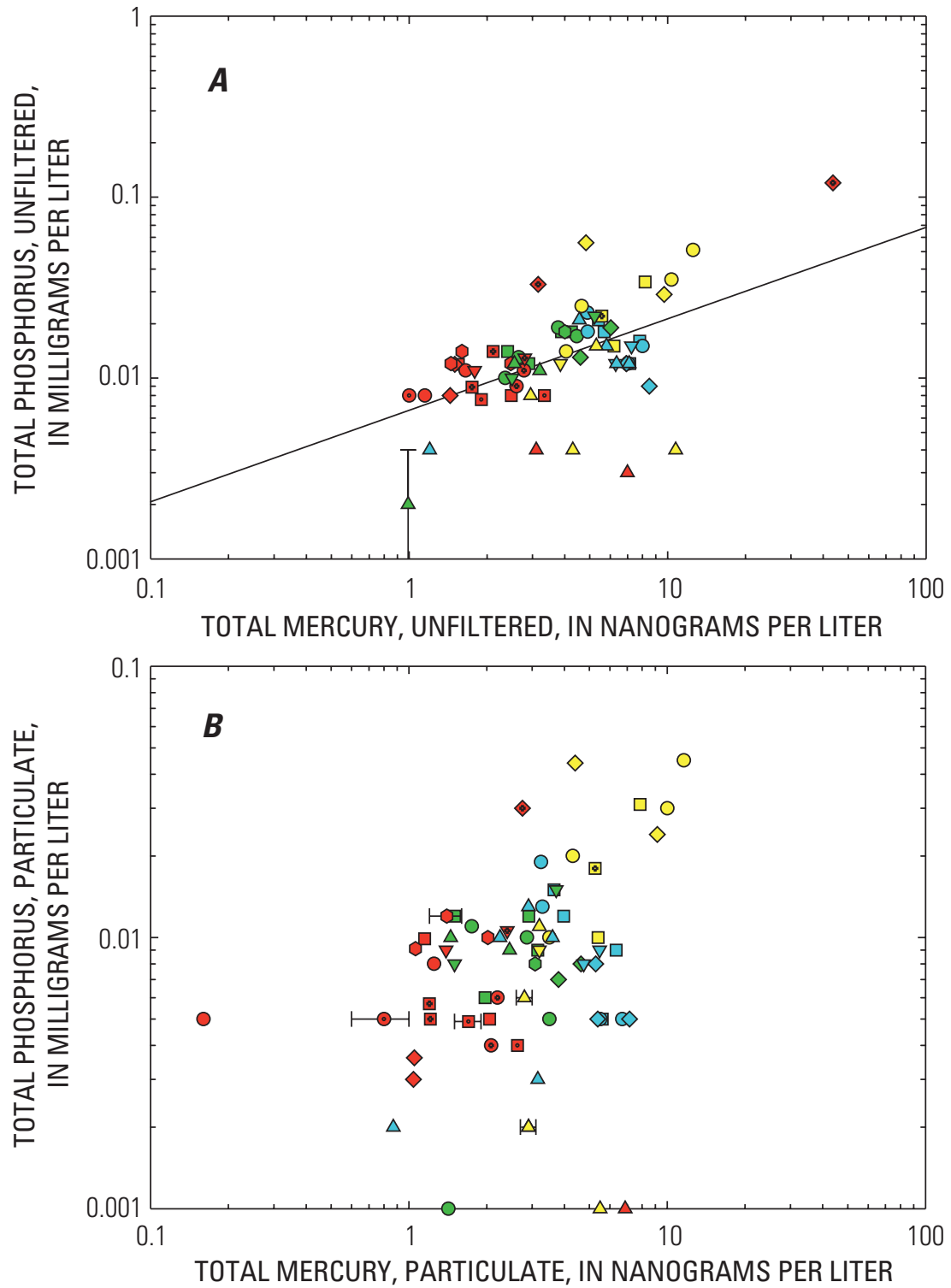

\begin{tabular}{lcccc} 
& \multicolumn{5}{c}{ EXPLANATION } \\
& Fall & Winter & Spring & Summer \\
Lower reservoir & $\square$ & $\square$ & $\square$ & $\square$ \\
Mid-reservoir & $\circ$ & 0 & 0 & $\circ$ \\
Bear River arm & $\diamond$ & $\diamond$ & $\diamond$ & $\diamond$ \\
Dairy Farm arm & $\nabla$ & $\nabla$ & $\nabla$ & $\nabla$ \\
Rock Creek arm & $\diamond$ & $\bullet$ & $\bullet$ & $\bullet$ \\
Dairy Farm Mine & $\Delta$ & $\Delta$ & $\Delta$ & $\Delta$ \\
pit lake and & & & & \\
impoundments & $\square \circ \diamond \nabla$ & Solid symbol indicates epilimnion \\
& $\square \odot$ & & Dot indicates metalimnion \\
& $\square \odot \diamond$ & Cross indicates hypolimnion
\end{tabular}

Figure 27. Relations between concentrations of mercury species and phosphorus in water samples from Camp Far West Reservoir, California, 2001-03: (A) Total mercury and total phosphorus in unfiltered water, $(B)$ Particulate total mercury and particulate total phosphorus, (C) Methylmercury and total phosphorus in unfiltered water, $(D)$ Particulate methylmercury and particulate total phosphorus. Best values of total mercury used, as explained in text and in table 6. Particulate total phosphorus concentrations calculated as difference between total phosphorus in unfiltered water and total phosphorus in filtered water. Line in $(A)$ is linear least-squares regression in log-log transform coordinates. Error bars represent measurements less than method detection limit (MDL), with corresponding symbol plotted at 50 percent of MDL. 

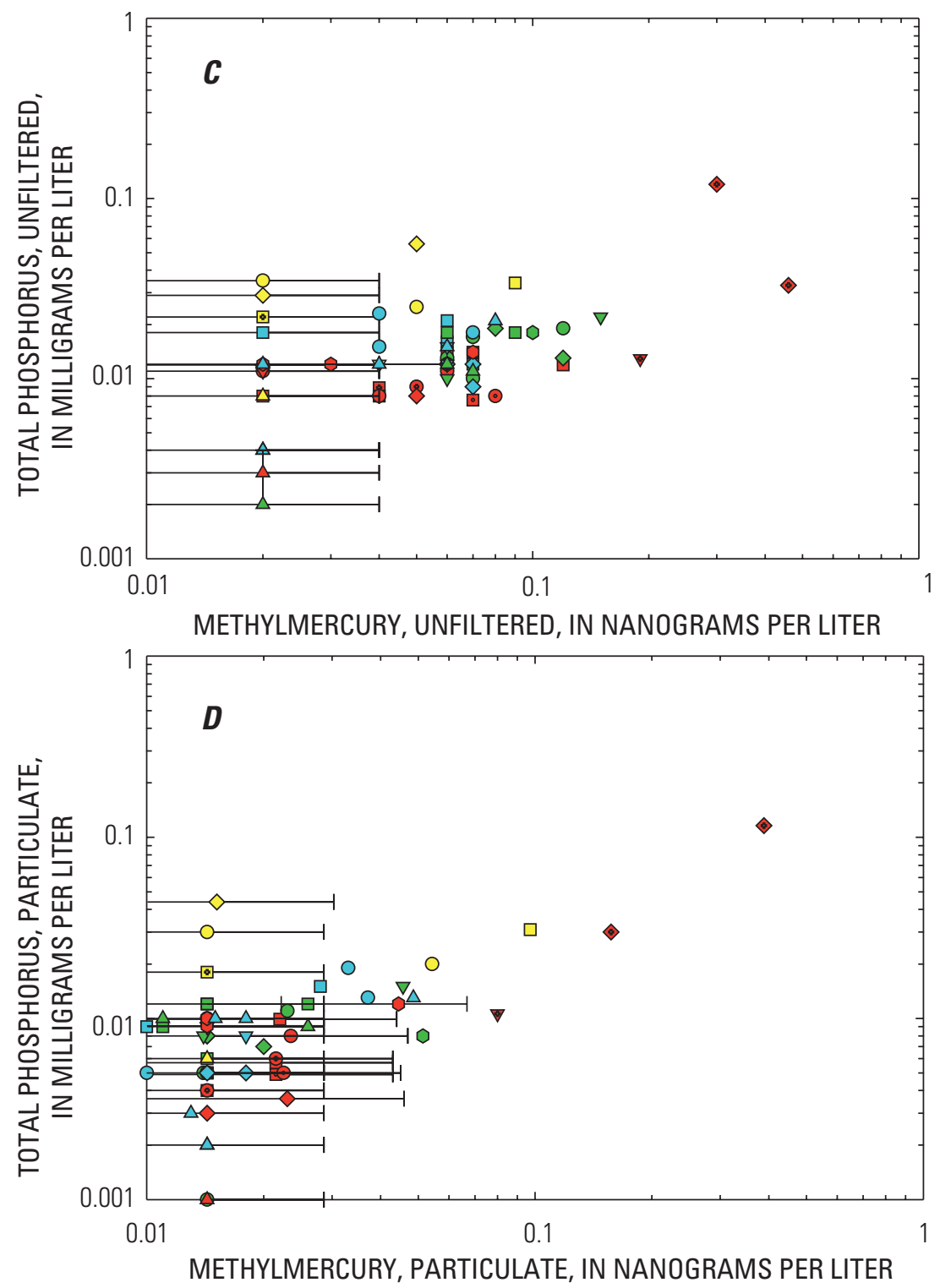

\section{EXPLANATION}

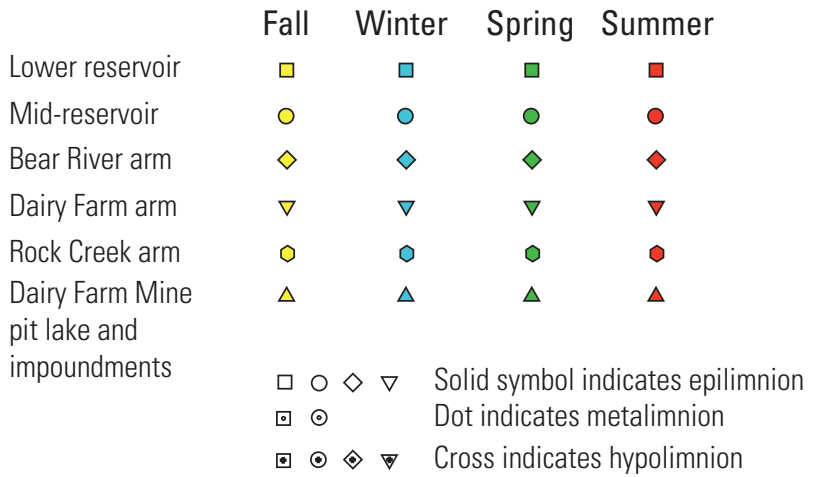

Figure 27. Continued. 

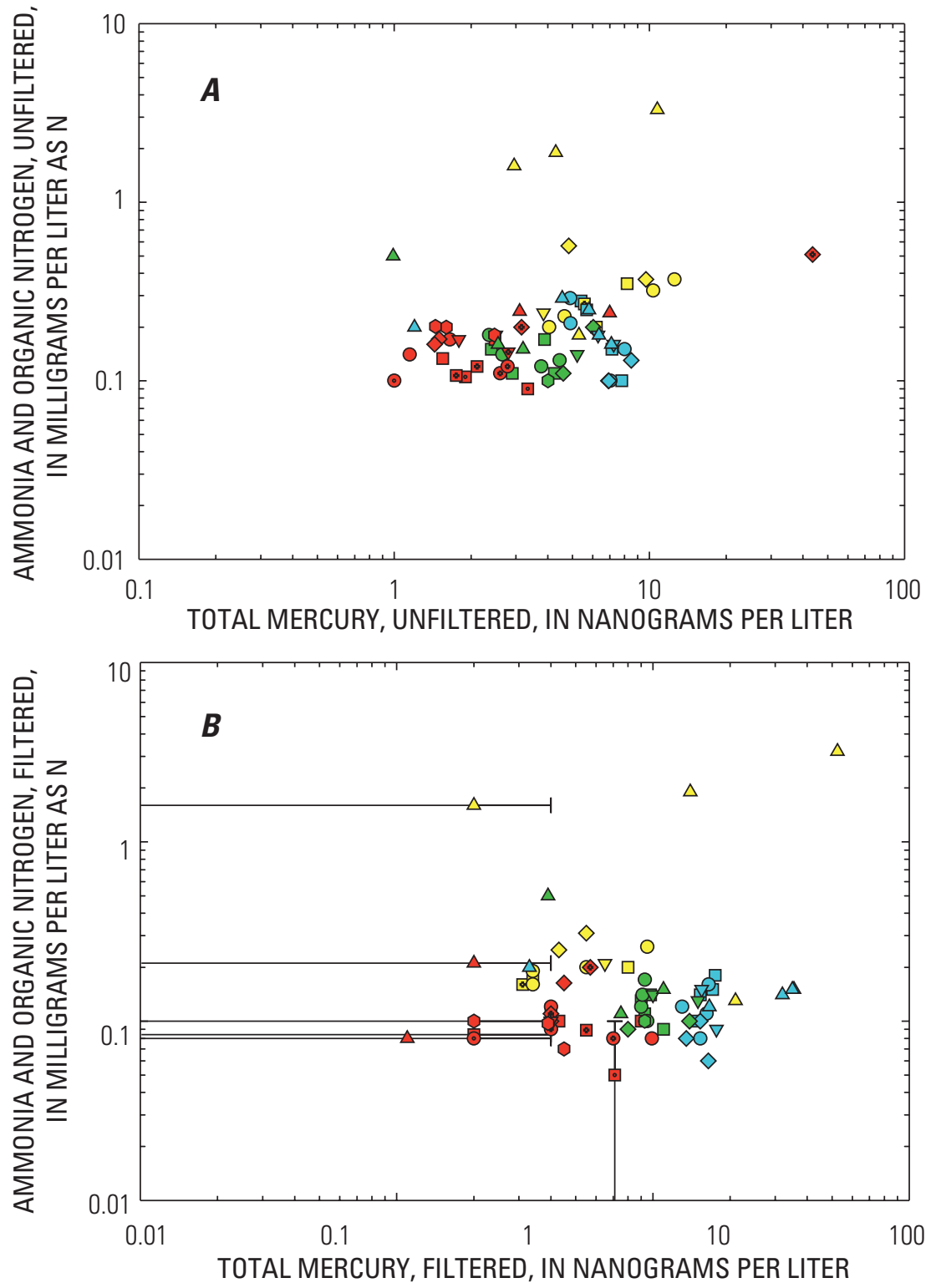

\section{EXPLANATION}

$\begin{array}{lllll}\text { Lower reservoir } & \square & \square & \square & \square \\ \text { Mid-reservoir } & \circ & 0 & \circ & \circ \\ \text { Bear River arm } & \diamond & \diamond & \diamond & \diamond \\ \text { Dairy Farm arm } & \nabla & \nabla & \nabla & \nabla \\ \text { Rock Creek arm } & \diamond & \diamond & \bullet & \bullet \\ \begin{array}{l}\text { Dairy Farm Mine } \\ \text { pit lake and }\end{array} & \Delta & \Delta & \Delta & \Delta \\ \text { impoundments } & \square \circ \diamond \nabla & \text { Solid symbol indicates epilimnion } \\ & \square \odot & & \text { Dot indicates metalimnion } \\ & \square \odot \diamond \nabla & \text { Cross indicates hypolimnion }\end{array}$

Figure 28. Relations between mercury and nitrogen concentrations in water samples from Camp Far West Reservoir, California, 2001-03: (A) total mercury and ammonia plus organic nitrogen in unfiltered water, $(B)$ total mercury and ammonia plus organic nitrogen in filtered water, $(C)$ total particulate mercury and particulate ammonia plus organic nitrogen, $(D)$ methylmercury and ammonia plus organic nitrogen in unfiltered water. Best values of total mercury used, as explained in text and in table 6 . Particulate ammonia plus organic nitrogen (N) concentrations calculated as difference between total ammonia plus organic nitrogen in unfiltered water and ammonia plus organic nitrogen in filtered water. Error bars represent measurements less than method detection limit (MDL), with corresponding symbol plotted at 50 percent of MDL. 

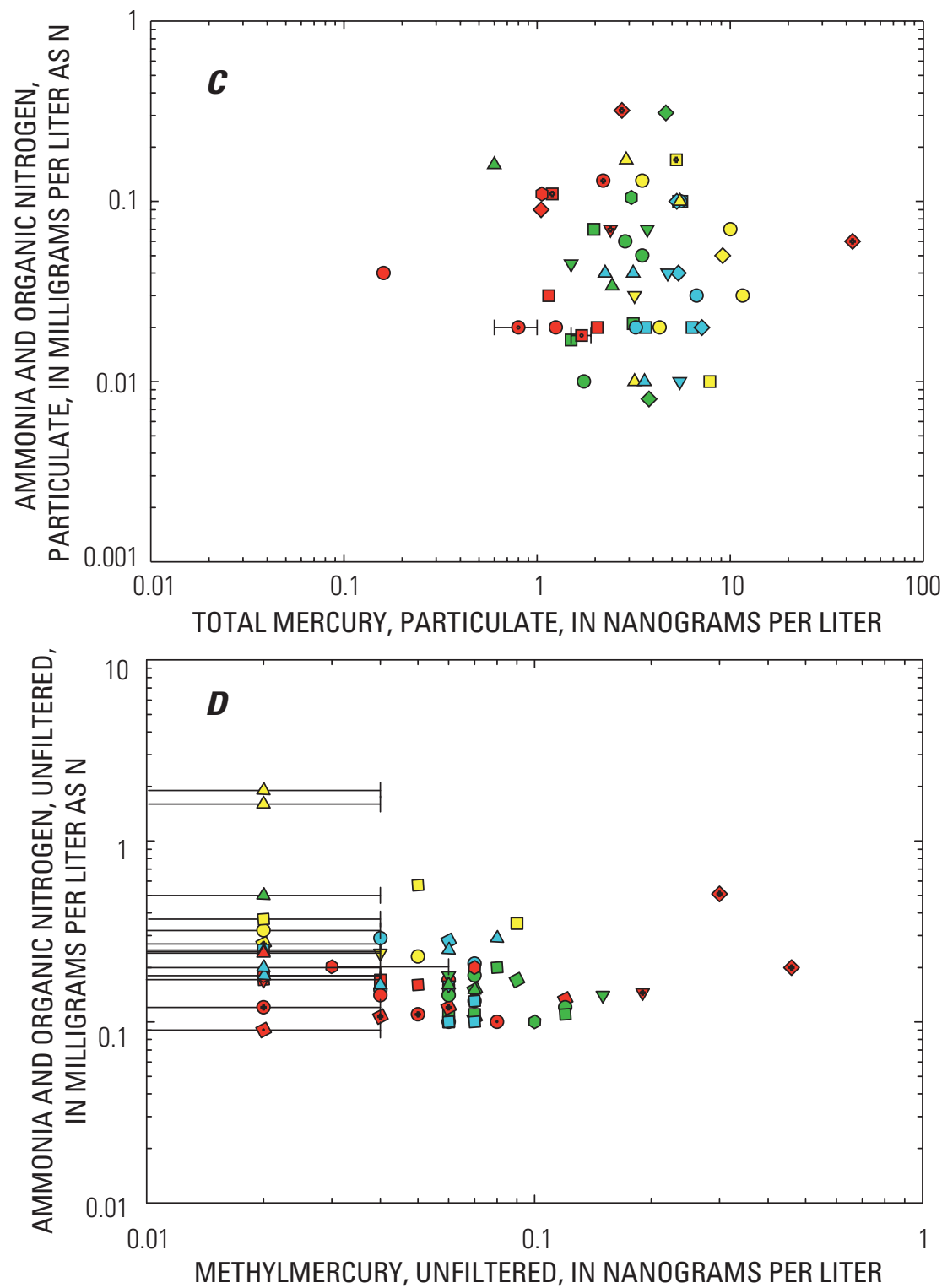

EXPLANATION

\begin{tabular}{|c|c|c|c|c|}
\hline Lower reservoir & $\square$ & $\square$ & $\square$ & $\square$ \\
\hline Mid-reservoir & O & 0 & O & ○ \\
\hline Bear River arm & $\diamond$ & $\diamond$ & $\diamond$ & $\diamond$ \\
\hline Dairy Farm arm & $\nabla$ & $\nabla$ & $\nabla$ & $\nabla$ \\
\hline Rock Creek arm & 0 & 0 & 0 & 0 \\
\hline $\begin{array}{l}\text { Dairy Farm Mine } \\
\text { pit lake and }\end{array}$ & $\Delta$ & $\Delta$ & $\Delta$ & $\Delta$ \\
\hline impoundments & $\begin{array}{l}\square \circ \diamond \\
\square \odot\end{array}$ & $\nabla$ & $\begin{array}{l}\text { Solid symb } \\
\text { Dot indica }\end{array}$ & $\begin{array}{l}\text { ates epilimnion } \\
\text { alimnion }\end{array}$ \\
\hline
\end{tabular}

Figure 28. Continued. 

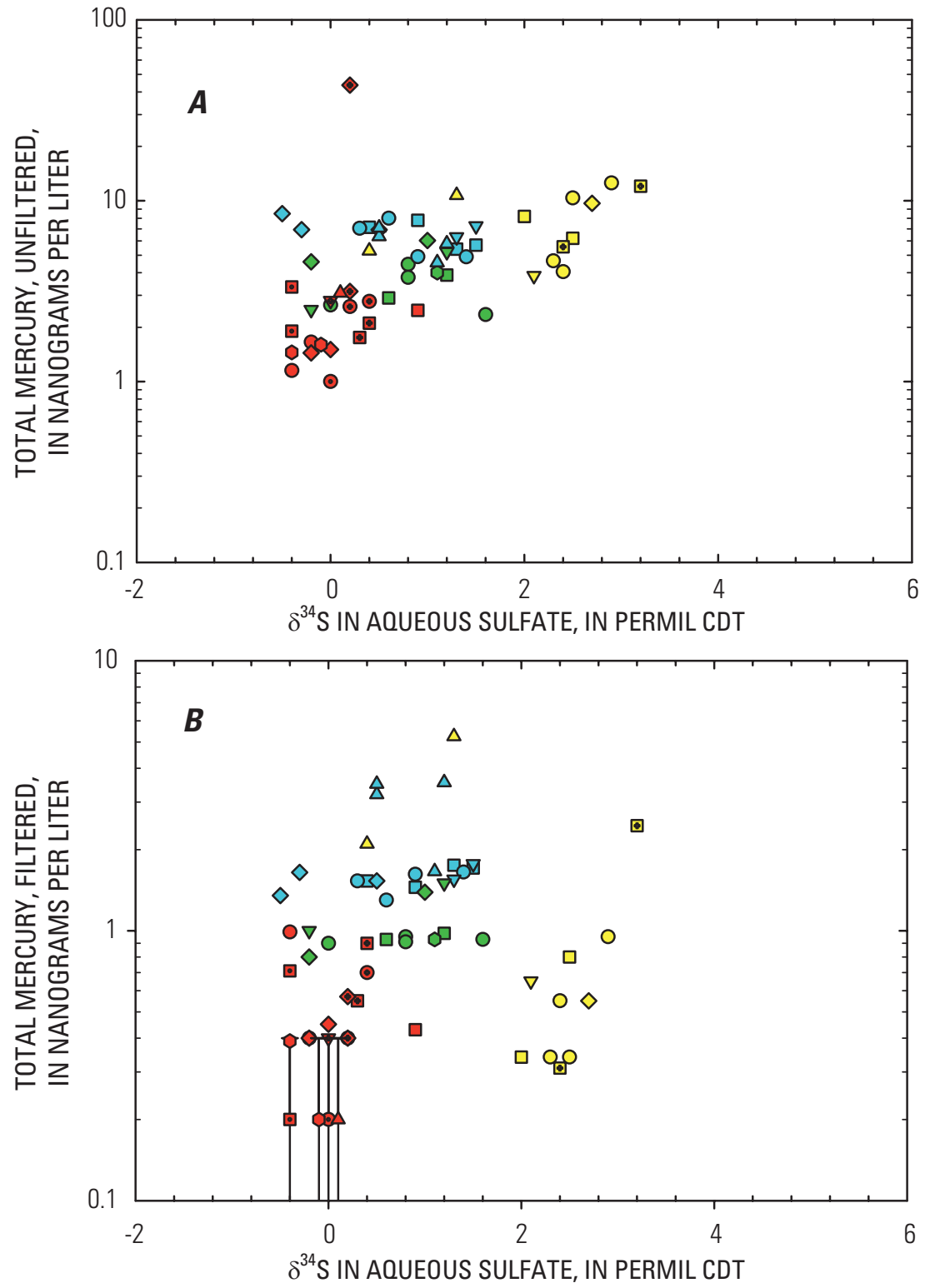

EXPLANATION

$\begin{array}{lccccc} & \text { Site Number } & \text { Fall } & \text { Winter } & \text { Spring } & \text { Summer } \\ \text { Lower reservoir } & 1,2 & \square & \square & \square & \square \\ \text { Mid-reservoir } & 3,4 & 0 & 0 & \circ & 0 \\ \text { Bear River arm } & 5 & \diamond & \diamond & \diamond & \diamond \\ \begin{array}{l}\text { Dairy Farm arm } \\ \text { Rock Creek arm }\end{array} & 6 & \nabla & \nabla & \nabla & \nabla \\ \begin{array}{l}\text { Dairy Farm Mine } \\ \text { pit lake and }\end{array} & 8,9 & \Delta & \Delta & \Delta & \Delta \\ \text { impoundments } & \square \odot \diamond \nabla & \text { Solid symbol indicates epilimnion } \\ & \square \odot & \text { Dot indicates metalimnion } & \\ & \square \odot \diamond \nabla & \text { Cross indicates hypolimnion }\end{array}$

Figure 29. Relation between sulfur isotopes in aqueous sulfate and total mercury in water, 2001-03: $(A)$ total mercury in unfiltered water, $(B)$ total mercury in filtered water. Best values of total mercury used, as explained in text and in table $6 . \delta^{34} \mathrm{~S}$, delta-34-sulfur value, CDT, Cañon Diablo Troilite. Error bars represent measurements less than method detection limit (MDL), with corresponding symbol plotted at 50 percent of MDL. 


\section{Bioaccumulation Factors}

Bioaccumulation factors (BAF) were computed using data from linked studies of mercury bioaccumulation in seven biological taxa: spotted bass, bluegill, threadfin shad, crayfish, mayfly nymphs, midge larvae, and zooplankton (Stewart and others, 2008). A simplified approach to assigning pelagic biota to trophic levels that was used by the U.S. Environmental Protection Agency (1997) in its assessment of mercury bioaccumulation factors is used and extended in this report for BAF analysis. The USEPA approach makes the simplifying assumption that aquatic food chains can be adequately represented using four trophic levels. According to the U.S. Environmental Protection Agency (1997),

"These trophic levels are the following: level 1 - phytoplankton (algal producers); level 2 zooplankton (primary herbivorous consumers); level 3 - small forage fish (secondary consumers); and level 4 - larger, piscivorous fish (tertiary consumers). This type of food chain typifies the pelagic assemblages found in large freshwater lakes, and has been used extensively to model bioaccumulation of hydrophobic organic compounds. It is recognized, however, that food chain structure can vary considerably among aquatic systems resulting in large differences in bioaccumulation in a given species of fish. In addition, this simplified structure ignores several important groupings of organisms, including benthic detritivores, macroinvertebrates, and herbivorous fishes."
According to the USEPA classification system, spotted bass are considered trophic level (TL) 4, bluegill and threadfin shad are TL 3, and zooplankton are TL 2. Although invertebrates such as those sampled in CFWR are not strictly addressed in the USEPA classification system, midge larvae and mayfly nymphs are largely detritivores and would be analogous to TL 2, and crayfish are secondary consumers that would be analogous to TL 3 .

Significant variations of total mercury in tissue and organism length were observed for all three fish species (figs. 30A-30C) and for total mercury and length in crayfish (fig. 30D). Samples for these four taxa were divided into size classes, and average concentrations and standard deviations were computed for each size class (figs. 31A-31D). Bioaccumulation factors (BAF) were computed (table 10, and appendix $\mathrm{H}$, tables $\mathrm{H1}-\mathrm{H6}$ ) using the average methylmercury concentration (wet) in biota divided by the mean concentration of methylmercury in filtered water (0.04 nanogram per liter). For the three fish species, total mercury concentrations in fillet tissue were used as an approximation of methylmercury concentrations. Analyses of fish from CFWR and elsewhere indicate that $\mathrm{MeHg} / \mathrm{Hg}_{\mathrm{T}}$ in fish tissue is usually between 0.61 and 0.95 (Bloom, 1992; Mason and others, 2006). Average $\mathrm{MeHg} / \mathrm{Hg}_{\mathrm{T}}$ values for spotted bass and bluegill from CFWR were 0.87 and 0.93 , respectively. As expected, the BAF values increased systematically with trophic level. Values of BAF were 190,000 for zooplankton (TL 2); 470,000 to 930,000 for three taxa of invertebrates (analogous to TLs 2 and 3); 2.7 million for threadfin shad (whole body; TL 3); 4.2 million for bluegill (fillet; TL 3); and 10 million for spotted bass (fillet; TL 4). The U.S. Environmental Protection Agency (1997) computed MeHg BAF values for TL 4 by a number of methods using carefully screened data from a small number

Table 10. Summary of methylmercury bioaccumulation factors, Camp Far West Reservoir, California, 2002-03.

[BAF, bioaccumulation factor; L/kg, liter per kilogram; -, not determined]

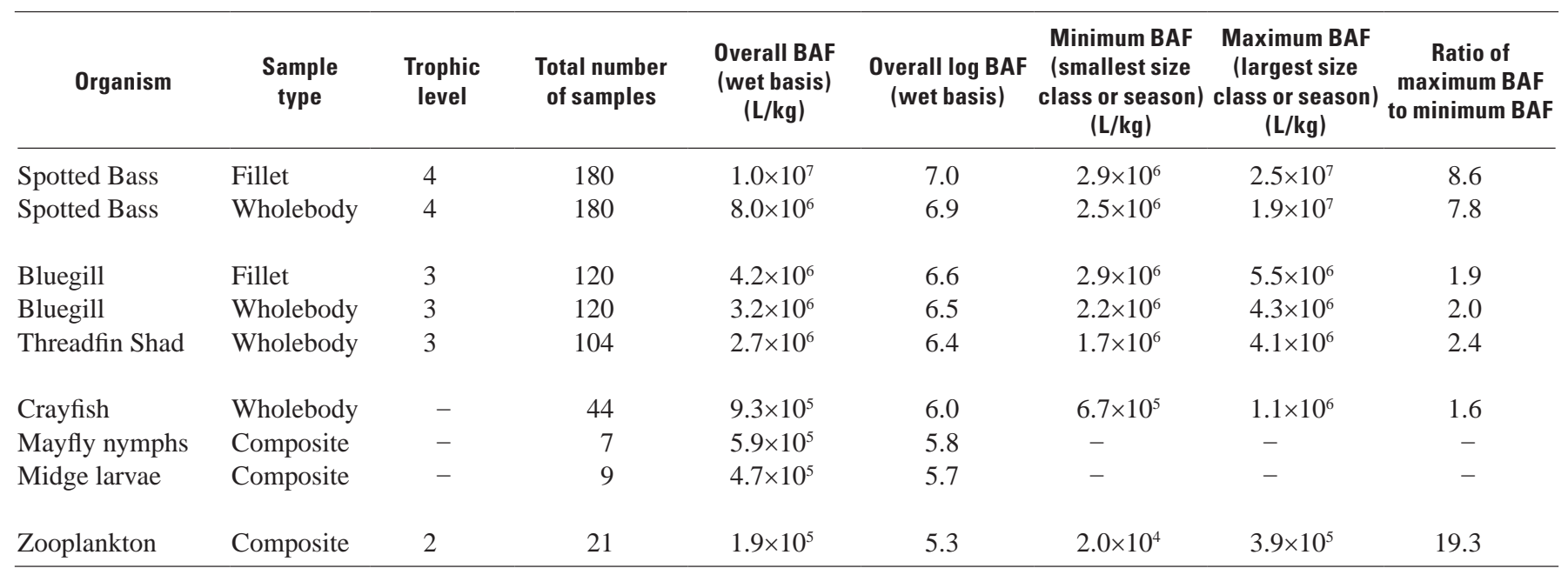



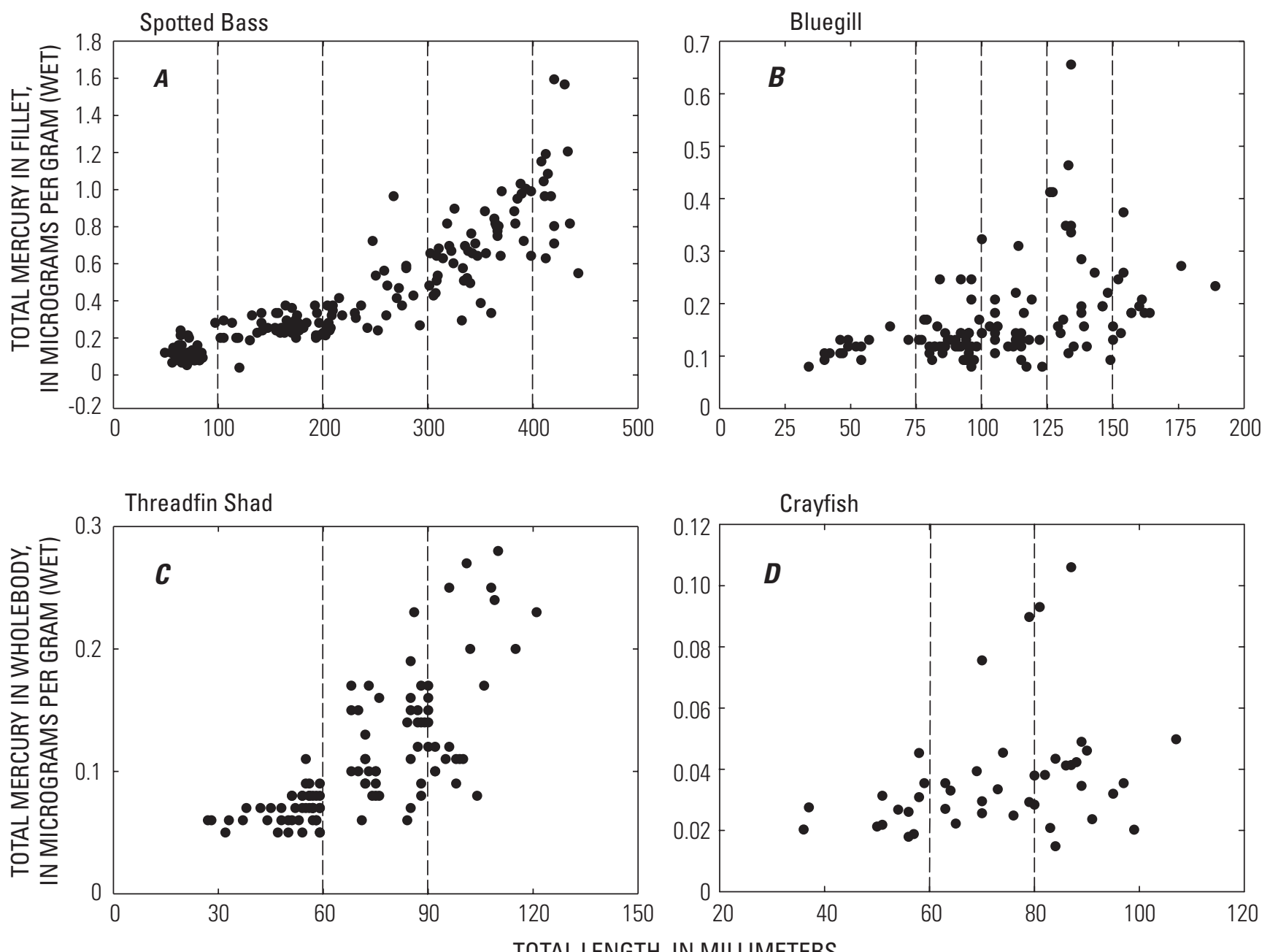

Figure 30. Plots showing relations of total length and total mercury in tissue of selected fishes and crayfish, Camp Far West Reservoir, 2002-03: (A) Spotted bass, (B) Bluegill, (C) Threadfin shad, (D) Crayfish. Dashed vertical lines represent boundaries between size classes selected for calculation of methylmercury bioaccumulation factors. Concentrations of mercury in fillet tissue of spotted bass and bluegill calculated from whole body concentrations using results of linear least-squares regression (20 samples for spotted bass, 15 samples for bluegill).

of studies around the country and derived a recommended value of 6.8 million. The BAF value for spotted bass at CFWR (10 million) is around the 80th percentile of the distribution presented by U.S. Environmental Protection Agency (1997) for TL 4. For TL 3, the U.S. Environmental Protection Agency (1997) computed a BAF of 1.6 million. The BAFs for threadfin shad and bluegill at CFWR were higher than this value. The threadfin shad BAF (2.7 million) is between
USEPA's 50th and 85th percentiles for TL3 and the bluegill BAF (4.2 million) is between USEPA's 87.5th and 95th percentiles. The BAFs from CFWR also are somewhat higher than those observed in other reservoirs in northern California (for example, Kuwabara and others, 2005), indicating a relatively efficient biomagnification of mercury in Camp Far West Reservoir. 

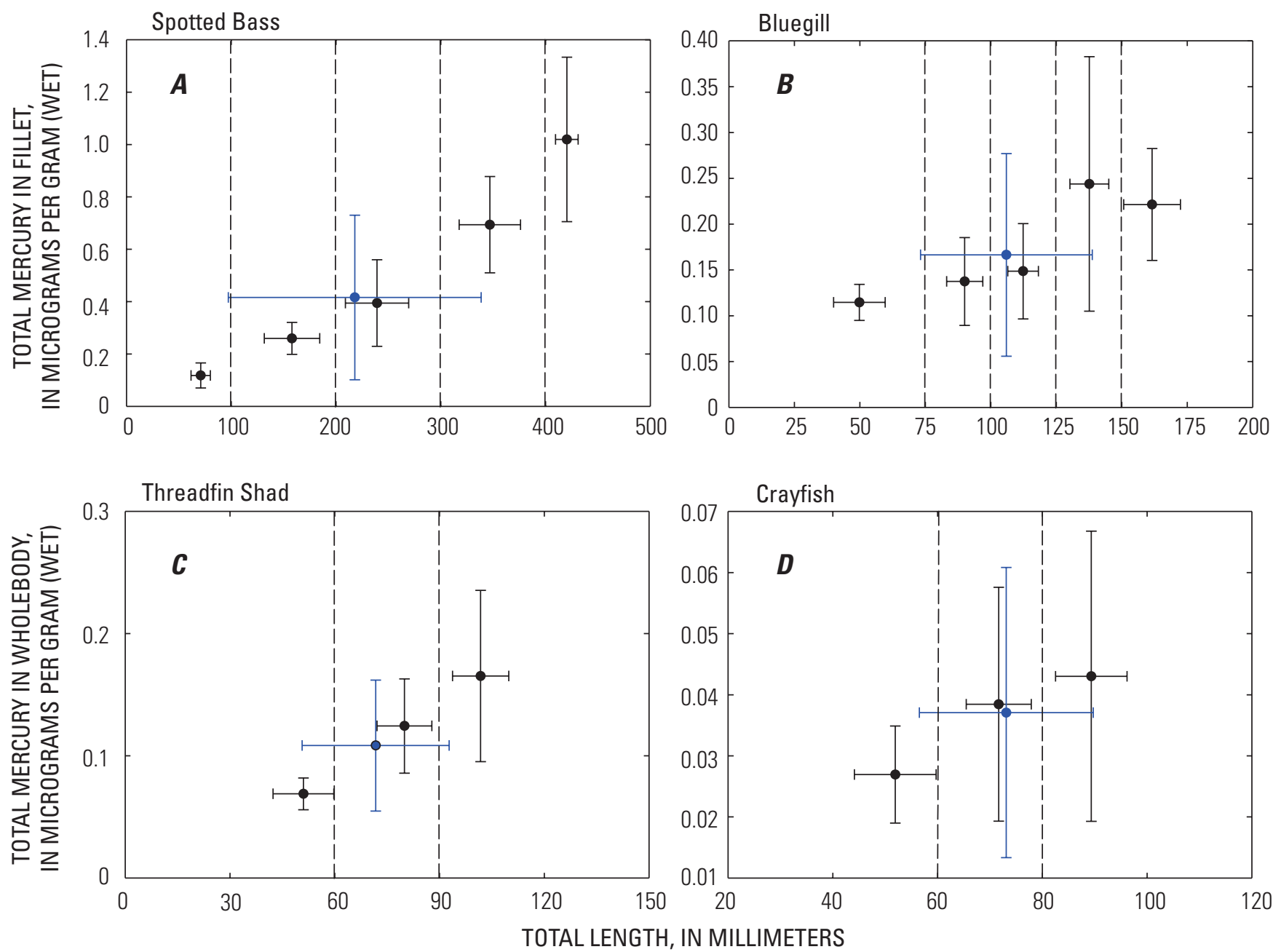

Figure 31. Plot showing relation of average and standard deviation of total length and total mercury in fillet tissue in selected size classes of fishes and crayfish from Camp Far West Reservoir, California, 2002-03: (A) Spotted bass, (B) Bluegill, (C) Threadfin shad, (D) Crayfish. Dashed vertical lines represent boundaries between size classes selected for calculation of methylmercury bioaccumulation factors. Average and standard deviation for individual size classes shown in black; average and standard deviation for all samples of each species shown in blue. Concentrations of total mercury in fillet tissue of spotted bass and bluegill calculated from whole body concentrations using results of linear least-squares regression (20 samples for spotted bass, 15 samples for bluegill). 


\section{Summary and Conclusions}

The water quality in Camp Far West Reservoir (CFWR) was characterized by eight quarterly sampling events over a 2-year period (fall 2001 through summer 2003) at several locations within the reservoir as part of a multi-disciplinary project focused on mercury transport, transformation, and bioaccumulation in the Bear River watershed. Robust seasonal variations were observed in several water-quality constituents including major cations and anions, total mercury (in both filtered and unfiltered samples), nitrogen (ammonia plus organic), and total phosphorus. A strong seasonal signal also was observed for the sulfur isotope composition of aqueous sulfate from filtered water. The reservoir experienced severe drawdown to less than 8 percent of its total storage during October and November 2002, which had the effect of accentuating seasonal trends in water quality caused by variations in the chemistry of input water from the Bear River.

The reservoir is monomictic, with thermal stratification developing in the summer and continuing into the early fall. During stratified conditions, low concentrations of dissolved oxygen generally were observed in the lower, cool zone (hypolimnion) and occasionally in the transition zone (metalimnion). Because of extreme drawdown during late summer and early fall, the hypolimnion was available for sampling only at the deepest sites in the thalweg (original river channel). Evaporative effects are seen by a shift of about 2 permil in $\delta^{18} \mathrm{O}_{\mathrm{H} 2 \mathrm{O}}$, confined to the epilimnion (surface layer) in the summer and fall. The Dairy Farm Mine pit lake becomes hydrologically separated from CFWR during low stage (summer and fall), during which time it becomes acidic and metalliferous. When water levels rise in winter, the sulfaterich, acidic water of the pit lake mixes with CFWR, so the mine acts a source of sulfate and metals to CFWR.

Highest concentrations of total mercury (filtered and unfiltered water) were observed during fall and winter; these concentrations declined at most stations during spring and into summer. Aqueous methylmercury concentrations were highest during summer sampling at deep-water stations in the anoxic, hypolimnion zone, especially in the Bear River arm of the reservoir. The ratio of methylmercury to total mercury $\left(\mathrm{MeHg} / \mathrm{Hg}_{\mathrm{T}}\right)$ increased systematically from winter to spring to summer, largely in response to the decrease in total mercury concentrations, but also to some extent because of increases in MeHg during the summer.
It is hypothesized that $\mathrm{MeHg}$ is produced in the anoxic parts of the water column and also in shallow bed sediment by sulfate-reducing bacteria. Conditions are optimal for this during late summer and early fall when the reservoir is thermally stratified. This coincides with the timing of a phytoplankton bloom. Primary production of phytoplankton in CFWR is phosphate-limited. Concentrations of orthophosphate were very low or below detection at all stations. It has been hypothesized that iron-reducing bacteria release phosphorus from iron-rich sediments in CFWR during summer and early fall, stimulating the phytoplankton bloom. When the reservoir destratifies (turns over) in the late fall, the MeHg produced in the hypolimnion (and perhaps also the metalimnion) is released to the entire water column.

Stable isotopes of sulfur in aqueous sulfate indicate a shift toward larger values of $\delta^{34} S$ in the fall. Based on correlations of $\delta^{34} \mathrm{~S}_{\mathrm{SO} 4}$ with concentrations of sulfate and calcium and correlations among the major cations and anions, the principal source of aqueous sulfate causing the fall increase in $\delta^{34} \mathrm{~S}_{\mathrm{SO} 4}$ appears to be the Bear River input to CFWR. Microbially mediated sulfate reduction and its seasonality within CFWR sediments likely plays an important role in Hg methylation; however, the seasonal changes in $\delta^{34} \mathrm{~S}_{\mathrm{SO} 4}$ of Bear River input water coupled with the extreme drawdown of CFWR during fall precludes the use of sulfur isotopes to track sulfate-reduction processes in the reservoir.

Bioaccumulation factors were computed using data from linked studies of mercury bioaccumulation in seven biological taxa over a range of trophic levels: zooplankton, midge larvae, mayfly nymphs, crayfish, threadfin shad, bluegill, and spotted bass. Significant increases in total mercury in fillet tissue with fish size were observed for all three fish species and for crayfish. Bioaccumulation factors (BAF) were computed using the average total mercury or methylmercury concentration (wet) in biota divided by the mean concentration of methylmercury in filtered water ( 0.04 nanograms per liter). As expected, the BAF values increased systematically with increasing trophic level (TL, based on U.S. Environmental Protection Agency, 1997). Values of BAF were: 190,000 for zooplankton (TL 1); 470,000 to 930,000 for three taxa of invertebrates (TL 2); 2.7 million for threadfin shad (whole body; TL 3); 4.2 million for bluegill (fillet; TL 3) and 10 million for spotted bass (fillet; TL 4). The BAF values are somewhat higher than those observed in other reservoirs in northern California, indicating a relatively efficient biomagnification of mercury in Camp Far West Reservoir. 


\section{Acknowledgments}

The authors are grateful to the California State Water Resources Control Board (SWRCB) and the U.S. Geological Survey Cooperative Water Program for funding the work described in this report. Rick Humphreys of the SWRCB assisted with field work and contract management. Brad Arnold and other staff of the South Sutter Water District provided useful information regarding water management at Camp Far West Reservoir. USGS personnel and employees of Sacramento State University Enterprises, Inc. who contributed significantly to this project include Stacy Burnett, Michael Casselberry, Michelle Chao, Connie Clapton, Susan Davis, Peter Dileanis, Stephanie Dudash, Mary Elizabeth, Mary Gibson, Scott Hamlin, Jerry Harmon, Michael Hunerlach, Kelly McPherson, Frank Moseanko, Lisa Olsen, Anthony Paulson, Raef Porter, Yvonne Roque, Larry Shelton, Sylvia Stork, and David Uyematsu.

\section{References Cited}

Alpers, C.N., and Hunerlach, M.P., 2000, Mercury contamination from historic gold mining in California: U.S. Geological Survey Fact Sheet 061-00, 6 p. Also available at http://ca.water.usgs.gov/mercury/fs06100.html

Alpers, C.N., Hunerlach, M.P., May, J.T., and Hothem, R.L., 2005a, Mercury contamination from historical gold mining in California: U.S. Geological Survey Fact Sheet 20053014, 6 p. Also available at http://pubs.water.usgs.gov/ fs2005-3014

Alpers, C.N., Hunerlach, M.P., May, J.T., Hothem, R.L., Taylor, H.E., Antweiler, R.C., De Wild, J.F., and Lawler, D.A., 2005b, Geochemical characterization of water, sediment, and biota affected by mercury contamination and acidic drainage from historical gold mining, Greenhorn Creek, Nevada County, California, 1999-2001: U.S. Geological Survey Scientific Investigations Report 2004-5251, 278 p. Also available at http://pubs.usgs.gov/ sir/2004/5251/

Alpers, C.N., Taylor, H.E., and Domagalski, J.L., eds., 2000, Metals transport in the Sacramento River, California, 19961997. Volume 1. Methods and Data: U.S. Geological Survey Water-Resources Investigations Report 99-4286, 430 p. Also available at http://pubs.usgs.gov/wri/wrir 994286/

Averill, C.V., 1946, Placer mining for gold in California: California State Division of Mines and Geology Bulletin 135, $336 \mathrm{p}$.
Babiarz, C.L., Hurley, J.P., Hoffmann, S.R., Andren, A.W., Shaferk, M.M., and Armstrong, D.E., 2001, Partitioning of total mercury and methylmercury to the colloidal phase in freshwaters: Environmental Science \& Technology, v. 35, p. 4773-4782.

Bloom, N.S., 1992, On the chemical form of mercury in edible fish and marine invertebrate tissue: Canadian Journal of Fish and Aquatic Sciences, v. 49, no. 5, p. 1010-1017.

Bowie, A.J., 1905, A practical treatise on hydraulic mining in California: New York, Van Nostrand, 313 p.

Brenton, R.W., and Arnett, T.L., 1993, Methods of analysis by the U.S. Geological Survey National Water Quality Laboratory: Determination of dissolved organic carbon by UV-promoted persulfate oxidation and infrared spectrometry: U.S. Geological Survey Open-File Report 92-480, $12 \mathrm{p}$.

Brigham, M.E., Krabbenhoft, D.P., and Hamilton, P.A., 2003, Mercury in stream ecosystems-New studies initiated by the U.S. Geological Survey: U.S. Geological Survey Fact Sheet 016-03, 4 p. Also available at http://pubs.usgs.gov/fs/ fs-016-03/

California Department of Water Resources, 2005, Reservoir information, Bear River at Camp Far West Dam: California Data Exchange Center. Accessed November 15, 2005 at http://cdec.water.ca.gov/cgi-progs/ profile?s=CFW\&type $=$ res

California Regional Water Quality Control Board, Central Valley Region, 2003, CWA (Clean Water Act) Section 303(D) List of Water Quality Limited Segment (approved July 2003 by the U.S. Environmental Protection Agency) 23 p. Accessed July 28, 2004, at http://www.swrcb.ca.gov/ tmdl/docs/2002reg5303dlist.pdf

Caruso, B.S., Cox, T.J., Runkel, R.L., Velleux, M.L., Bencala, K.E., Nordstrom, D.K., Julien, P.Y, Butler, B.A., Alpers, C.N., Marion, A., and Smith, K.S., 2008, Metals fate and transport modelling in streams and watersheds: state of the science and USEPA workshop review: Hydrologic Processes, v. 22, p. 4011-4021.

CH2M Hill, 2001, Public Release Draft Remedial Investigation Report, Lava Cap Mine Superfund Site, Nevada County, California, Volume 1: Report and Appendixes A-D, Prepared for U.S. Environmental Protection Agency, Region IX, San Francisco, Calif. Accessed January 12, 2005, at http://www.epa.gov/ region09/cleanup/california.html

Choe, K.-Y. and Gill, G.A., 2001, Isolation of colloidal monomethyl mercury in natural waters using cross-flow ultrafiltration techniques: Marine Chemistry, v. 76, p. 305-318. 
Choe, K.-Y. and Gill, G.A., 2003, Distributions of particulate, colloidal and dissolved mercury in the San Francisco Bay estuary: 2. Monomethyl mercury: Limnology and Oceanography, v. 48, no. 4, p. 1547-1556. Also available at http://wwww.aslo.org/lo/toc/vol 48/issue 4/1547.pdf

Choe, K.-Y., Gill, G.A., and Lehman, R.D., 2003, Distributions of particulate, colloidal and dissolved mercury in the San Francisco Bay estuary: 1. Total mercury: Limnology and Oceanography, v. 48, No. 4, p. 1535-1546. Also available at http://wwww.aslo.org/lo/toc/vol 48/ issue 4/1535.pdf

Churchill, R.K., 2000, Contributions of mercury to California's environment from mercury and gold mining activities; Insights from the historical record, in Extended abstracts for the U.S. Environmental Protection Agency sponsored meeting, Assessing and Managing Mercury from Historic and Current Mining Activities: November 28-30, 2000, San Francisco, Calif., p. 33-36 and S35-S48. Also available at: http://www.epa.gov/nrmrl/ pubs/625r04102/625r04102.pdf

Clark, L.D., 1976, Stratigraphy of the north half of the Western Sierra Nevada metamorphic belt, California: U.S. Geological Survey Professional Paper 923, 26 p., 1 plate.

Clark, W.B., 1963, Gold districts of California: California Department of Conservation, Division of Mines and Geology: Bulletin 193, 199 p., 1 plate (some revisions through 1969; 7th printing, 1998).

Coleman, M.L., Shepherd, T.J., Durham, J.J., Rouse, J.E., and Moore, G.R., 1982, Reduction of water with zinc for hydrogen isotope analysis: Analytical Chemistry, v. 54, p. 993-995.

Compeau, G., and Bartha, R., 1985, Sulphate-reducing bacteria: principal methylators of mercury in anoxic estuarine sediments: Applied Environmental Microbiology, v. 50, p. $498-502$.

Craig, H., Gordon, L.I,, and Horibe, T., 1963, Isotope exchange effects in the evaporation of water. 1. Lowtemperature experimental results: Journal of Geophysical Research, v. 68, no. 7, p. 5079-5087.

De Wild, J.F., Olson, M.L., and Olund, S.D., 2002, Determination of methylmercury by aqueous phase ethylation, followed by gas chromatographic separation with cold vapor atomic fluorescence detection: U.S. Geological Survey Open-File Report 01-445. Also available at http://pubs.usgs.gov/of/2001/ofr-01-445/

Domagalski, J.L., Knifong, D.K., Dileanis, P.D., Brown, L.R., May, J.T., Connor, V., and Alpers, C.N., 2000, Water Quality in the Sacramento River Basin, California, 1994-98: U.S. Geological Survey Circular 1215, 36 p. Also available at http://pubs.usgs.gov/circ/circ1215/
Epstein, S., and Mayeda, T., 1953. Variation of 180 content of waters from natural sources: Geochimica et Cosmochimica Acta, v. 4, p. 213-224.

Fishman, M.J., 1993, Methods of analysis by the U.S. Geological Survey National Water Quality Laboratory: Determination of inorganic and organic constituents in water and fluvial sediments: U.S. Geological Survey OpenFile Report 93-125, 217 p.

Fishman, M.J., and Friedman, L.C., eds., 1989, Methods of determination of inorganic substances in water and fluvial sediments: U.S. Geological Survey Techniques of WaterResources Investigations, book 5, chap. A-1, 545 p.

Fry, B.N., Brand, W., Mersch, F.J., Tholke, K., and Garritt, R., 1992, Automated-analysis system for coupled delta-C-13 and delta-N-15 measurements: Analytical Chemistry, v. 64, p. 288-291.

Garbarino, J.R., and Taylor, H.E., 1996, Inductively coupled plasma-mass spectrometric method for the determination of dissolved trace elements in natural water: U.S. Geological Survey Open-File Report No. 94-358, 88 p.

Gilbert, G.K., 1917, Hydraulic-mining debris in the Sierra Nevada. U.S. Geological Survey Professional Paper 105, $154 \mathrm{p}$.

Gilmour, C.C., Henry, E.A., and Mitchell, R., 1992, Sulfate stimulation of mercury methylation in freshwater sediments: Environmental Science \& Technology, v. 26, p. 2281-2287.

Helsel, D.R., 2005, Nondetects and Data Analysis-Statistics for Censored Environmental Data: Hoboken, New Jersey, John Wiley \& Sons, Inc., 250 p.

Heyl, G.R., 1948, Foothill copper-zinc belt of the Sierra Nevada, California, in Bramel, H.R., Cox, M.W., Eric, J.H., Heyl, G.R., Ransome, A.L., and Wyant, D.G., eds., Copper in California: California Division of Mines and Geology Bulletin, v. 144, p. 11-29.

Hunerlach, M.P., and Alpers, C.N., 2003, Mercury contamination from hydraulic gold mining in the Sierra Nevada, California, in Gray, J.E., ed., Geologic Studies of Mercury by the U.S. Geological Survey: U.S. Geological Survey Circular 1248, 41 p.

Hunerlach, M.P., Rytuba, J.J., and Alpers, C.N., 1999, Mercury contamination from hydraulic placer-gold mining in the Dutch Flat mining district, California, in Morganwalp, D.W., and Buxton, H.T., eds., U.S. Geological Survey Toxic Substances Hydrology Program-Proceedings of the Technical Meeting, Charleston, South Carolina, March 8-12, 1999: U.S. Geological Survey WaterResources Investigations Report 99-4018B, p. 179-189. Also available at http://ca.water.usgs.gov/mercury/dutch/ wrir994018b.pdf 
Ingraham, N.L., 1998, Isotopic variation in precipitation, in Kendall, C., and McDonnell, J.J., eds., Isotope Tracers in Catchment Hydrology: New York, Elsevier, p. 87-188.

James, L.A., 1991, Quartz concentration as an index of sediment mixing: hydraulic mine-tailings in the Sierra Nevada, California: Geomorphology, v. 4, p. 125-144.

James, L.A., 1993. Sustained reworking of hydraulic mining sediment in California: G.K. Gilbert's sediment wave model reconsidered: Zeitschrift für Geomorphologie, Suppl.- Bd. 88, p. 49-66.

Kester, C.L., Rye, R.O., Johnson, C.A., Schwartz, C.C., and Holmes, C.W., 2001, Online sulfur isotope analysis of organic matter by direct combustion: preliminary results and potential applications: Isotopes in Environmental and Health Studies, v. 37, p. 53-65.

Klasing, S., and Brodberg, R., 2003, Evaluation of potential health effects of eating fish from selected water bodies in the northern Sierra Nevada Foothills (Nevada, Placer, and Yuba Counties): Guidelines for Sport Fish Consumption, December 2003, 46 p. Also available at http://www.oehha. ca.gov/fish/so cal/nosierra.html

Krabbenhoft, D.P., Wiener, J.G., Brumbaugh, W.G., Olson, M.L., DeWild, J.F., and Sabin, T.J., 1999, A national pilot study of mercury contamination of aquatic ecosystems along multiple gradients, in Morganwalp, D.W., and Buxton, H.T., eds., U.S. Geological Survey Toxic Substances Hydrology Program: Proceedings of the Technical Meeting, Charleston, South Carolina, March 8-12,1999, Contamination of Hydrologic Systems and Related Ecosystems, v. 2: U.S. Geological Survey WaterResources Investigation Report 99-4018B. Also available at http://toxics.usgs.gov/pubs/wri99-4018/Volume2/ sectionB/2301 Krabbenhoft/

Kuwabara, J.S., Alpers, C.N., Marvin-DiPasquale, M., Topping, B.R., Carter, J.L., Stewart, A.R., Fend, S.V., Parchaso, F., Moon, G.E., and Krabbenhoft, D.P., 2003, Sediment-water interactions affecting dissolved-mercury distributions in Camp Far West Reservoir, California: U.S. Geological Survey Water-Resources Investigations Report 03-4140, 64 p. Also available at http://pubs.usgs.gov/wri/ $\underline{\text { wri034140/ }}$

Kuwabara, J.S., Topping, B.R., Moon, G.E., Husby, P., Lincoff, A., Carter, J.L., and Croteau, M.-N., 2005, Mercury accumulation by lower trophic-level organisms in lentic systems within the Guadalupe River Watershed, California: U.S. Geological Survey Scientific Investigations Report 2005-5037, 59 p. Also available at http://pubs.usgs.gov/ $\underline{\text { sir/2005/5037/ }}$
Lindgren, W., 1911, The Tertiary gravels of the Sierra Nevada of California: U.S. Geological Survey Professional Paper 73, 226 p.

Loyd, R., 1995, Mineral land classification of Placer, County, California: California Department of Conservation, Division of Mines and Geology Open File Report 95-10, 66 p., 3 appendixes, 7 plates.

Mason, R.P., Heyes, D., and Sveinsdottir, A., 2006, Methylmercury concentrations in fish from tidal waters of the Chesapeake Bay: Archives of Environmental Contamination and Toxicology, v. 51, p. 425-437.

May, J.T., Hothem, R.L., Alpers, C.N., and Law, M.A., 2000, Mercury bioaccumulation in fish in a region affected by historic gold mining: The South Yuba River, Deer Creek, and Bear River watersheds, California, 1999: U.S. Geological Survey Open-File Report 00-367, 30 p. Also available at http://ca.water.usgs.gov/archive/reports/ ofr00367/index.html

Mitko, K., and Bebek, M., 1999, ICP-OES determination of trace elements in salinated water: Atomic Spectroscopy, v. 20, p. 217-223.

Mitko, K., and Bebek, M., 2000, Determination of major elements in saline water samples using a dual-view ICPOES: Atomic Spectroscopy, v. 21, p. 77-85.

Olson, M.L., and De Wild, J.F., 1999, Techniques for the collection and species-specific analysis of low levels of mercury in water, sediment, and biota, in Morganwalp, D.W., and Buxton, H.T., eds., U.S. Geological Survey Toxic Substances Hydrology Program: Proceedings of the Technical Meeting, Charleston, South Carolina, March 8-12, 1999: U.S. Geological Survey Water-Resources Investigations Report 99-4018B, v. 2, p. 191-199. Also available at http://toxics.usgs.gov/pubs/wri99-4018/ Volume2/sectionB/2305 Olson/pdf/2305 Olson.pdf

Patton, C.J., and Truitt, E.P., 1992, Methods of analysis by the U.S. Geological Survey National Water Quality LaboratoryDetermination of total phosphorus by a Kjeldahl digestion method and an automated colorimetric finish that includes dialysis: U.S. Geological Survey Open-File Report 92-146, 39 p.

Poppe, L.J., Eliason, A.H., Fredericks, J.J., Rendigs, R.R., Blackwood, D., and Polloni, C.F., 2000, Chapter 1: Grainsize analysis of marine sediments: Methodology and data processing, chap. 1 of USGS East-Coast Sediment Analysis: Procedures, Database, and Georeferenced Displays: U.S. Geological Survey Open-File Report 00-358. Also available at http://pubs.usgs.gov/of/of00-358/text/chapter1.htm 
Regnell, O., Tunlid, A., Ewald, G., and Sangfors, O., 1996, Methyl mercury production in freshwater microcosms affected by dissolved oxygen levels: role of cobalamin and microbial community composition: Canadian Journal of Fisheries and Aquatic Science, v. 53, p. 1535-1545.

Roth, D.A., 1994, Ultratrace analysis of mercury and its distribution in some natural waters of the United States: Fort Collins, Colo., Colorado State University, Ph.D. dissertation, $309 \mathrm{p}$.

Roth, D.A., Taylor, H.E., Domgalaski, J., Dileanis, P., Peart, D.B., Antweiler, R.C., and Alpers, C.N., 2001, Distribution of inorganic mercury in Sacramento River water and suspended colloidal sediment material: Archives of Environmental Contamination and Toxicology, v. 40, no. 2, p. 161-172.

Seal, R.R., II, Alpers, C.N., and Rye, R.O., 2000, Stable isotope systematics of sulfate minerals, in Alpers, C.N., Jambor, J.L, and Nordstrom, D.K., eds., Sulfate Minerals: Crystallography, Geochemistry, and Environmental Significance: Mineralogical Society of America and Geochemical Society, Washington, D.C., Reviews in Mineralogy and Geochemistry, v. 40, p. 541-602.

Shelton, L.R., 1994, Field guide for collecting and processing stream-water samples for the National Water-Quality Assessment Program: U.S. Geological Survey Open-File Report 94-455, 42 p.

Slotton, D.G., Ayers, S.M., Reuter, J.E., and Goldman, C.R., 1997, Gold mining impacts on food chain mercury in northwestern Sierra Nevada streams, Appendix B of Larry Walker Associate, Sacramento River Watershed mercury control planning project-report for the Sacramento Regional County Sanitation District, 74 p.

Stewart, A.R., Saiki, M.K., Kuwabara, J.S., Alpers, C.N., Marvin-DiPasquale, M., and Krabbenhoft, M.P., 2008, Influence of plankton mercury dynamics and trophic pathways on mercury concentrations of top predator fish of a mining-impacted reservoir: Canadian Journal of Fisheries and Aquatic Sciences, v. 65, p. 2351-2366, doi:10.1139/ F08-140.

Taylor, H.E., 2001, Inductively coupled plasma-mass spectrometry-practices and techniques: San Diego, Calif., Academic Press, 294 p.
U.S. Environmental Protection Agency, 1990, Guidelines establishing test procedures for the analysis of pollutants, Appendix B, part 136 of Definition of procedures for the determination of the MDL-Revision 1.11, revised July 1, 1999, p. 537-539.

U.S. Environmental Protection Agency, 1997, Mercury Study Report to Congress, Volume III: Fate and Transport of Mercury in the Environment, EPA-452/R-97-005, December 1997, 376 p. Also available at http://www.epa. gov/mercury/report.htm

Verplanck, P. L., Antweiler, R.C., Nordstrom, D.K., and Taylor, H.E., 2001, Standard reference water samples for rare earth element determinations: Applied Geochemistry, v. 16, p. 231-241.

Waring, C.A., 1919, Placer County, in Hamilton, F., ed., Mines and Mineral Resources of Portions of California: Report number 15 of the State Mineralogist, part 3, chap. 2, p. 327-8.

Wershaw, R.L., Fishman, M.J., Grabbe, R.R., and Lowe, L.E., 1987, Methods for the determination of organic substances in water and fluvial sediments: U.S. Geological Survey Techniques of Water-Resources Investigations, book 5 , chap. A3, 80 p.

Western Regional Climate Center, 2004a, Period of record monthly climate summary, Grass Valley, California. Accessed October 4, 2004, at http://www.wrcc.dri.edu/cgibin/cliRECtM.pl?cagras

Western Regional Climate Center, 2004b, Period of record monthly climate summary, Auburn, California. Accessed June 14, 2005, at http://www.wrcc.dri.edu/cgi-bin/ cliRECtM.pl?caaubu

Wetzel, R.G., 1975, Limnology: Philadelphia, Penn., W.B. Saunders Co., 743 p.

Wetzel, R.G., 2001, Limnology (3d ed.): London, Academic Press, 1006 p.

Yeend, W.E., 1974, Gold-bearing gravels of the ancestral Yuba River, Sierra Nevada, California: U.S. Geological Survey Professional Paper 772, 44 p. 


\section{Appendixes}

Appendix data can be accessed by downloading files at http://pubs.usgs.gov/sir/2006/5008.

Appendix A. Plots Showing Relations of Reservoir Storage, Surface Water Elevation, and Time, Camp Far West Reservoir, California.

Appendix B. Tables Describing Sampling Stations and Frequency of Sampling, Camp Far West Reservoir and Vicinity, California.

Appendix C. Tables of Data Describing Water-Column Profiles, Camp Far West Reservoir, California.

Appendix D. Plots Showing Water-Column Depth Profiles of Temperature, Dissolved Oxygen, pH, and Specific Conductance, Camp Far West Reservoir, California, 2001-03.

Appendix E. Tables of Data Related to Quality Assurance and Quality Control.

Appendix F. Quality Assurance and Quality Control Figures.

Appendix G. Data for Total Mercury, Other Trace Elements, Major Elements, and Chlorophyll.

Appendix H. Data Tables for Methylmercury Bioaccumulation Factors, Camp Far West Reservoir, California. 


\section{Glossary}

auriferous Gold-bearing.

benthos Forms of aquatic life that are bottom dwelling.

bioaccumulation factor (BAF) The concentration ratio of a constituent in biological tissue divided by the concentration of that same constituent in water. In the case of methylmercury, BAF values presented in this report are computed as the concentration in fish or invertebrate tissue divided by the concentration of methylmercury in filtered water.

demethylation (of methylmercury) The process of converting methylmercury to an inorganic form of mercury. Demethylation may be caused by abiotic processes (such as exposure to ultraviolet light) as well as biotic processes (such as microbial activity).

elemental mercury The pure form of mercury, the only element to be stable as a liquid at room temperature; also known as quicksilver.

epilimnion In thermally stratified lakes or reservoirs, the upper, more or less uniformly warm, circulating, and fairly turbulent water.

flux Transport of a constituent. Bed sediment flux in a reservoir refers to transport of a constituent from the pore water of the bed sediment to the overlying water column by the process of aqueous diffusion.

impaired beneficial use The condition of a water body that is not meeting water-quality standards, according to the federal Clean Water Act of 1972.

hypolimnion In thermally stratified lakes or reservoirs, the deep, cold, and relatively undisturbed region.

load The quantity of material carried by a natural transporting agent per unit time. For aqueous constituents in rivers, the load (mass per time) is computed as the product of the aqueous concentration (mass per volume) and the discharge rate (volume per time). Typical units for sediment loads are tons per day and for mercury loads are grams or kilograms per year.

lognormal distribution The probability distribution of any random variable whose logarithm is normally distributed. If $\mathrm{x}$ is a random variable with a normal distribution, then $\exp (\mathrm{x})$ has a log-normal distribution.

metalimnion In thermally stratified lakes or reservoirs, the transition zone between the upper, warm zone (epilimnion) and lower, cold zone (hypolimnion). methylation (of mercury) The process of converting an inorganic form of mercury to methylmercury, an organic (carbon-bearing) form. It is generally accepted that mercury methylation is largely caused by the activity of microbes, particularly sulfate-reducing bacteria.

methylmercury (MeHg) An organic form of mercury (formula $\mathrm{CH}_{3} \mathrm{Hg}^{+}$) that is readily bioaccumulated. It is more toxic to humans and other biota than native (elemental) mercury.

micromole per liter Concentration unit for aqueous constituents. Conversion of concentration data from milligrams per liter $(\mathrm{mg} / \mathrm{L})$ to micromoles per liter $(\mu \mathrm{mol} / \mathrm{L})$ is by the formula $1,000 *(\mathrm{mg} / \mathrm{L}) / \mathrm{MW}=\mu \mathrm{mol} / \mathrm{L}$, where $\mathrm{MW}$ is the molecular weight of the constituent in units of grams per mole.

monomictic lake (or reservoir) A water body that is thermally stratified during one part of the year and circulates freely during the remainder of the year. Warm monomictic lakes (those with temperatures that do not drop below $4^{\circ}$ Celsius) typically stratify in the summer (Wetzel, 1975).

placer gold Gold grains or flakes in an unconsolidated sediment deposit. Also known as alluvial gold.

Relative Percentage Difference (RPD) Quantity computed for the evaluation of precision (or variability) of laboratory analytical data using randomly submitted split samples. $\mathrm{RPD}=100 \times$ (absolute value of difference between reported values) / (average reported value)

Relative Standard Deviation (RSD) A quantity computed for the evaluation of precision (or variability) of data. Relative standard deviation is the standard deviation of a series of measurements divided by the average of those measurements times 100

$\mathrm{RSD}=100 \times($ standard deviation $) /($ average reported value $)$

thalweg The submerged river channel that represents the deepest water in a reservoir at a given distance from the dam.

total mercury $\left(\mathbf{H g}_{\mathrm{T}}\right)$ The sum of all forms or species of mercury in a sample of water, sediment, or biota. 
This page left intentionally blank 
For more information concerning the research in this report, contact the Director, California Water Science Center,

U.S. Geological Survey, $6000 \mathrm{~J}$ Street Placer Hall

Sacramento, CA 95819

http://ca.water.usgs.gov 
